UNIVERSIDADE DE SÃO PAULO

FACULDADE DE EDUCAÇÃO

Thaís Cyrino de Mello Forato

\title{
A Natureza da CiênCia Como Saber Escolar: \\ UM ESTUDO DE CASO A PARTIR DA HISTÓRIA DA LUZ
}

VOLUME 1

SÃo PAULO

2009 


\title{
A NATUREZA da Cî̂NCIA COMo SABER ESCOLAR: UM ESTUDO DE CASO A PARTIR DA HISTÓRIA DA LUZ
}

\author{
VOLUME 1
}

Tese de Doutorado apresentada à Faculdade de Educação da Universidade de São Paulo para banca examinadora para obtenção do título de Doutor em Educação.

Área de Concentração: Ensino de Ciências e Matemática

Orientador: Prof. Dr. Maurício Pietrocola

Coorientador: Prof. Dr. Roberto de Andrade Martins

SÃO PAULO

2009 
Autorizo a reprodução e divulgação total ou parcial deste trabalho, por qualquer meio convencional ou eletrônico, para fins de estudo e pesquisa, desde que citada a fonte.

Catalogação na Publicação

Serviço de Biblioteca e Documentação

Faculdade de Educação da Universidade de São Paulo

375.2 Forato, Thaís Cyrino de Mello

F692n A natureza da ciência como saber escolar: um estudo de caso a partir da

v. 1-2 história da luz / Thaís Cyrino de Mello Forato ; orientação Maurício

Pietrocola, coorientação Roberto de Andrade Martins. São Paulo : s.n., 2009.

2 v. : il. + anexos

Tese (Doutorado - Programa de Pós-Graduação em Educação. Área de Concentração : Ensino de Ciências e Matemática) - Faculdade de Educação da Universidade de São Paulo.

1. Ciências - Estudo e ensino 2. História da ciência - Filosofia 3. Óptica - História 4. Epistemologia 5. Didática I. Pietrocola, Maurício, orient. II. Martins, Roberto de Andrade, coorient. 
Thaís Cyrino de Mello Forato

A Natureza da Ciência como Saber Escolar:

um estudo de caso a partir da história da luz.

Tese de Doutorado apresentada à Faculdade de Educação da Universidade de São Paulo para banca examinadora para obtenção do título de Doutor em Educação.

Área de Concentração: Ensino de Ciências e Matemática.

Aprovada em 1

Banca Examinadora

Prof. Dr. Maurício Pietrocola (FEUSP)

Prof. ${ }^{\text {a }}$ Dr. ${ }^{\text {a }}$ Anna Maria Pessoa de Carvalho (FEUSP) - Membro Titular

Prof. Dr. Luiz Peduzzi (UFSC) Membro Titular

Prof. Dr. Elio Carlos Ricardo (FEUSP) Membro Suplente

Prof. ${ }^{\text {a }}$ Dr. ${ }^{\text {a }}$ Cibelle Celestino Silva (IFSC-USP) Membro Suplente
Prof. Dr. Roberto de Andrade Martins (IFUnicamp)

Prof. Dr. Manoel Roberto Robilotta (IFUSP) Membro Titular

Prof. Dr. Olival Freire (UFBA) Membro Titular

Prof. Dr. Alberto Villani (IFUSP) Membro Suplente

Prof. Dr. Charbel N. El-Hani (UFBA) Membro Suplente 
Para

René Mallet Cyrino

(Em memória) 


\section{AGRADECIMENTOS}

"A hora mais escura da noite é justamente aquela que podemos ver melhor as estrelas."

Charles A. Beard

Viver uma tese. Sentir alegria, raiva, culpa e paixão. Deslumbrar-se, desencantarse. Pessoas especiais partilharam comigo esse caminho.

Antes de tudo, quero agradecer aos maestros que me colocavam no ritmo e na cadência desse caminhar: meus orientadores.

Ao orientador, Prof. Dr. Maurício Pietrocola, agradeço a recepção e o acolhimento no grupo de pesquisa cujos pressupostos contribuíram para meu crescimento. Obrigada, Maurício, pela interlocução instigadora, pelos estímulos oferecidos e por não ter cedido aos meus apelos de permanecer no terreno teórico. Agradeço as sábias provocações que me fizeram escalar a montanha. Obrigada pelo apoio, pela parceria e pelo comprometimento, sobretudo, na difícil reta final.

Ao coorientador, Prof. Dr. Roberto de Andrade Martins, agradeço os conhecimentos partilhados, o apoio constante, a paciência e generosidade, por ouvir com interesse as incertezas que surgiam durante o processo de reflexão. Agradeço a compreensão silenciosa dos momentos difíceis que vivi. Agradeço o olhar crítico, inegociável, de precisão sempre cirúrgica. Obrigada, Roberto, pelas insubstituíveis viagens no tempo.

Maurício e Roberto, obrigada pelo respeito aos percalços nada fáceis da mudança de área. Só quem viveu esse desafio sabe como é dura a tarefa de conciliar expectativas.

Quero agradecer com admiração à Profa. Solange Fonseca, que compartilhou meu sonho e pelo seu empenho na tarefa de torná-lo realidade, e agradeço com saudades e carinho aos alunos que o materializaram. Agradeço o apoio dado pela direção e coordenação da Escola Estadual Prof. Dr. Laerte Ramos de Carvalho, fundamental para a realização desta pesquisa.

Agradeço à banca de qualificação, Profa. Dra. Anna Maria Pessoa de Carvalho e Prof. Dr. Luis Peduzzi, a leitura atenta e minuciosa, as sugestões e críticas que me 
ajudaram a corrigir o mapa e consolidar trajetos. Anna, obrigada pelos preciosos "cafés com dicas e boas risadas" ao longo desses quatro anos.

Amiga querida Maria Luiza Ledesma Rodrigues, obrigada pelo apoio sempre, pelo encorajamento e pela ajuda na criação do roteiro para o teatro.

Obrigada, Breno Arsioli Moura, querido amigo, por acompanhar de perto os passos desta tese, encorajando-me. Obrigada pela ajuda sempre, por partilhar a história, pela parceria e pelo ombro amigo nos momentos de crise.

Ricardo Karam, obrigada pela interlocução multidisciplinar e pelo apoio virtual e real. Obrigada por compartilhar deslumbramentos e por toda a ajuda desde sua chegada em 2008.

Obrigada, Maicol Martins Lopes Coelho, Esdras Vigiano e Maria Inês Ribas Rodrigues, amigos especiais e queridos, que me ajudaram lendo, comentando, corrigindo, criticando, obrigada! Muito obrigada!

Maria Cristina P. Stella de Azevedo, obrigada pela ajuda nas incursões no universo dos alunos. Obrigada pela presença e por todo apoio nos momentos difíceis.

Agradeço aos amigos que me ajudaram de diferentes modos, Cibelle Celestino Silva, Ana Paula Bispo, Juliana Hidalgo Ferreira e Ricardo Ammar Barros.

Quem disse que fada madrinha não existe? Só eu tenho três: Renata de Andrade, Silvia Dotta e Roseline Strieder. Meninas, obrigada por toda ajuda nos momentos escuros da madrugada. Pela mão estendida quando sentia os parágrafos me sufocando.

Obrigada, Prof. Dr. Elio Ricardo, pela incansável ajuda com a transposição didática. Ofereço-lhe uma homenagem no pseudônimo do aluno que se destacou nas argumentações.

Ivã Gurgel e Waldmir Araujo Neto, obrigada, amigos, pelos diálogos instigadores, pelas alegrias e lágrimas partilhadas e pela ajuda prestada.

Guilherme Brockington, obrigada pelas longas e frutíferas discussões, porque é importante ter um amigo com quem brigar nas trilhas de um doutorado.

Aos queridos Talita Romero, Maxwell Siqueira, Lucia Sasseron, Viviane Bricia e Estevam Rouxinol, obrigada pela convivência alegre, pelas dicas e interlocução criativa. 
Queridos do corredor de ensino do IFUSP, obrigada pela acolhida, pelo apoio e pelos momentos alegres, especialmente, Maria Regina Kawamura, Renata Ribeiro, Sônia Salém, Cristiano Mattos, Luciana Guimarães, Anne Scarinci, Cristina Leite, Gisele Watanabe, Marcília Barcelos, Frederico Ramos, Lígia Valente e Glauco dos Santos. Meu agradecimento especial aos membros da Secret Society Table Fourteen.

A todos os colegas do Lapef, agradeço o carinho e a colaboração. Especialmente, Ivani Lawall, Willie Douglas, Milton Schivanni e Nicolli Ferreira.

Agradeço ao Murici Polato a disponibilidade e a ajuda prestada na tomada dos dados.

Queridas tias: Leny Compagno Cyrino, obrigada pela ajuda com Joshua, Chevallard e outros franceses, e Célia Cyrino Pereira, obrigada por me ajudar com o mosaico das palavras.

Querida prima Carla Mello Moreira, obrigada pela ajuda enorme nos momentos finais, pelos estilos, formatos, modos e tons.

Fátima, Mônica, Silene, Andréia, Vanessa, Carla, Ana, Winston e a outra face da Luíza e do Maicol, amigas e amigos distantes da tese, mas próximos do coração, obrigada por me resgatarem para os momentos de pausa e vida social fora dos muros da academia.

Minha noninha querida, Octávia Compagno Cyrino, obrigada pelo exemplo de vida.

Tamyra, Mãe e Pai, obrigada por todo apoio, por toda ajuda, pelas viagens constantes, por compensarem minha ausência. Obrigada, obrigada!

Minhas filhas amadas, Manoela e Roberta, estrelas brilhantes da madrugada, obrigada pelos sorrisos, pela paciência e resignação. Perdoem-me pelas intermináveis horas roubadas pelo computador.

Ao meu amor Pedro, agradeço o apoio incondicional sempre. Obrigada pelo seu amor, pelo seu carinho, pela sua dedicação, pela sua compreensão. Obrigada por partilhar comigo essa jornada.

À Fapesp - Fundação de Amparo à Pesquisa do Estado de São Paulo - agradeço a concessão da bolsa de doutorado e o apoio financeiro para realização desta pesquisa no período de fevereiro de 2007 a junho de 2009. 
"Isso é impossivel, professora!"

"Professora, esse negócio tá me confundindo. Uma hora eu acredito que a luz é uma onda, outra hora eu acho que luz é um corpo. No final a gente vai chegar a uma conclusão do que é a luz?"

"Professora, esses corpúsculos são matéria? Mas essa matéria vem de onde, da luz? Por que a gente não sente?"

"A gente não entende como ou a gente não aceita o fato de falar que matéria sutil é uma coisa que não dá pra ver. Se é matéria é matéria."

"Eu não acredito em vácuo. Pensa no nada, você consegue ver? Imagina 'o nada'! Vai na sua cabeça 'o nada'?”

"Como que você quer que nós acreditemos na teoria do éter se nós não sabemos o que seria o éter?"

Manifestações de alunos 


\section{RESUMO}

A relevância de ensinar conteúdos sobre as ciências, e não apenas conteúdos científicos tradicionais, tem se intensificado nas pesquisas educacionais das últimas décadas. Nesse sentido, a história da ciência configura-se um recurso pedagógico interessante para tratar sobre a construção do conhecimento científico em ambiente escolar. Entretanto, a confluência das necessidades dos campos didático-pedagógico e históricoepistemológico prevê alguns obstáculos por enfrentar para transformar a natureza da ciência em saber escolar no ensino médio. Assim, buscamos analisar tais desafios e aventar propostas para seu enfrentamento mediante os fundamentos dos quadros teóricos estudados e de uma investigação empírica. Adotamos como estratégia metodológica o confronto entre tais desafios previstos com as dificuldades vivenciadas na elaboração, no acompanhamento da aplicação e na análise de um curso piloto para o ensino médio, aplicado em uma escola pública da zona sul da cidade de São Paulo. Utilizamos três episódios da história da luz para tratar de alguns aspectos epistemológicos que problematizavam, principalmente, uma visão empírico-indutivista da ciência. Foi possível mapear uma série de obstáculos, propor estratégias para enfrentá-los, aplicar tais estratégias em sala de aula e analisar os dados obtidos. Como resultado dessas etapas, obtivemos bons prognósticos para algumas propostas averiguadas e percebemos que algumas soluções requerem aprimoramento. A metodologia qualitativa das pesquisas educacionais guiou o planejamento, a coleta e a análise dos dados. Os resultados obtidos indicaram possibilidades de generalização que podem ser entendidas como parâmetros iniciais para pesquisa com a história e filosofia da ciência na educação científica.

Palavras-chave: Ensino de ciências; Natureza da ciência; História da ciência; História da luz; Transposição didática. 


\begin{abstract}
The relevance of teaching about science, instead of teaching only the traditional and systematized scientific concepts, has been an important issue for educational researches over the last decades. In this new approach, the use of history of science is a promising pedagogical strategy to introduce the development of scientific knowledge in the context of education. However, when one tries to reconcile the demands of both didactic-pedagogical and historic-epistemological fields, many obstacles become evident. Accordingly, this thesis analyzes the challenges that are faced and the emerging solutions obtained from the combination of a theoretical framework and an empirical investigation. The methodological strategy that was employed confronts those challenges with the elaboration, application and analysis of a pilot course on the history of optics for secondary school students. Three historical episodes concerning the theory of light were chosen in order to challenge students' naïve inductive-empiricist conceptions of the nature of science. We were able to identify a set of obstacles, to propose strategies to face them, to apply those strategies in real classroom situations and to analyze the data gathered from the recordings of the classes. As a result, we have developed viable solutions and realized that some of them still need to be improved. A qualitative research methodology guided our process of elaboration, application and data analysis of the teaching-learning sequence that was implemented. The results point out possibilities of generalization which can be regarded as initial parameters for future researches that focus on the use of history and philosophy of science in scientific education.
\end{abstract}

Keywords: Science teaching, Nature of science, History of science, History of light, Didactic transposition. 


\section{LISTA DE QUADROS}

Quadro 1: Título: Data da aula e número do arquivo ___ 66

Quadro 2: Estimativa do tempo de leitura requerido do professor (em horas) __ 95

10/9/2007 - Aulas 3 e 4 - Arquivo I__ 126

10/9/2007 - Aulas 3 e 4 - Arquivo I__ 128

10/9/2007 - Aulas 3 e 4 - Arquivo I__ 129

10/9/2007 - Aulas 3 e 4 - Arquivo I__ 131

10/9/2007 - Aulas 3 e 4 - Arquivo I__ 133

10/9/2007 - Aulas 3 e 4 - Arquivo I__ 140

11/9/2007 - Aulas 5 e 6 - Arquivo I___ 141

11/9/2007 - Aulas 5 e 6 - Arquivo I___ 142

12/9/2007 - Aulas 7 e 8 - Arquivo II __ 145

12/9/2007 - Aulas 7 e 8 - Arquivo III ___ 146

12/9/2007 - Aulas 7 e 8 - Arquivo III __ 147

13/9/2007 - Aulas 9 e 10 -Arquivo I _ 148

13/9/2007 - Aulas 9 e 10 - Arquivo I___ 149

13/9/2007 - Aulas 9 e 10 - Arquivo I__ 150

13/9/2007 - Aulas 9 e 10 - Arquivo I___ 150

13/9/2007 - Aulas 9 e 10 - Arquivo I__ 151

17/9/2007 - Aulas 13 e 14 - Arquivo I___ 158

17/9/2007 - Aulas 13 e 14 - Arquivo I___ 169

6/9/2007 - Aulas 1 e 2 - Arquivo I___ 174

13/9/2007 - Aulas 9 e 10 - Arquivo II ___ 175

13/9/2008 - Aulas 9 e 10 - Arquivo II ___ 176 


\section{SUMÁRIO DO VOLUME 1}

Apresentação 1

1. O ensino, a história e a natureza da ciência 7

1.1. O saber historicamente construído 7

1.2. A natureza da ciência na educação científica 11

1.2.1. Abordagens possíveis acerca da natureza da ciência 11

1.2.2. Riscos inerentes à distorção histórico-epistemológica ___ 13

1.2.3. Historiografia e ensino de ciências___ 16

1.2.4. Delimitando a concepção de natureza da ciência___ 23

1.3. Pressupostos e desafios _ 26

2. Saberes escolares _ 29

2.1. Os processos da construção do saber___ 31

2.1.1. A didática específica como ciência __ 33

2.1.2. Saberes acadêmicos no ensino de ciências___ 34

2.1.3. A sobrevivência de um saber __ 46

2.2. Desafios na transposição didática da história da ciência __ 47

2.2.1. Obstáculos estruturais da abordagem histórico-epistemológica na educação científica _ 50

2.2.2. Conflitos, dilemas e riscos

3. Desenvolvimento da pesquisa

3.1. O desenvolvimento da pesquisa __

3.1.1. A estratégia adotada

3.1.2. A dimensão teórica da pesquisa __ 58

3.1.3. A dimensão empírica da pesquisa — 59

3.1.4. Análise dos processos de interação na relação didática ___ 59

3.1.5. Metodologia qualitativa de análise___ 60

3.1.6. Obtenção dos dados no contexto da análise qualitativa ___ 65

3.2. A elaboração do curso piloto _ 67

3.2.1. A escolha do tema histórico __ 68

3.2.2. Os conteúdos selecionados

3.2.3. Pressupostos para a preparação do curso piloto ___ 75

3.2.4. Desenvolvimento dos textos para os alunos _ 75

3.2.5. Desenvolvimento da seqüência de atividades didáticas ___ 77

3.2.6. Material disponibilizado___ 85

3.2.7. Avaliação _ 87

3.3. $O$ apoio ao professor na aplicação do curso __ 87

3.3.1. Bibliografia fornecida ao professor

3.3.2. As reuniões com a professora e o desenvolvimento do curso _— 90

3.3.3. Tempo exigido do professor na aplicação do curso piloto ___ 
4.1. Desafios vivenciados durante a elaboração do curso _ـ 97

4.1.1. Obstáculos superáveis: construindo propostas ___ 99

4.1.2. Obstáculos a contornar: em busca de caminhos __ 109

4.2. Análise da aplicação do curso: a construção dos eventos de pesquisa __ 119

4.2.1. Evento Gregos _ـ 121

4.2.2. Evento Éter 138

4.2.3. Evento Young __ 162

4.3. Relatos e percepções: Um breve olhar para o processo _ 173

4.3.1. Recortes e descaminhos: a história da linha do tempo __ 173

4.3.2. A relação professora-alunos: afeto e valorização como diferencial ___ 175

4.4. Destacando resultados __ 177

4.4.1. Muitos textos: um risco?___ 177

4.4.2. Compensar a omissão da matemática com recursos visuais?___ 177

4.4.3. Entes inobserváveis: complexas abordagens___ 179

4.4.4. Atuação da professora na transposição didática interna.__ 179

4.4.5. Aprofundamento de alguns aspectos epistemológicos _ـ_ 180

Intermezzo__ 182

Considerações finais___ 183

Referências bibliográficas __ 197 




\section{Apresentação}

\begin{abstract}
"[...] muitos orientam o ensino destacando o fazer matemático como um ato de gênio, reservado a poucos, que, como Newton, são vistos como privilegiados pelo toque divino. $O$ resultado disso é uma educação de reprodução, formando indivíduos subordinados, passivos e acríticos."
\end{abstract}

Ubiratan D'Ambrósio

A idéia da ciência como um conhecimento neutro, puramente racional, atingido indutivamente a partir de experimentos objetivos vem sendo criticada desde as primeiras décadas do século XX. Diversos filósofos, sociólogos e historiadores da ciência propuseram teorias concebendo a ciência como uma construção humana parcial e falível, contestável, uma construção cultural. Trabalhos de diversos pensadores, como Gaston Bachelard e Thomas Kuhn, por exemplo, foram contribuindo para que as ciências exatas e as humanidades fossem deixando de ser consideradas como duas áreas antagônicas.

Entretanto, ainda se percebe amplamente disseminada uma concepção da ciência como um conhecimento construído apenas por pessoas geniais que descobrem as eternas verdades universais por meio de um infalível método científico. Tal visão é constantemente reforçada pela mídia e pelo próprio ensino de ciências. Quem nunca ouviu um frutífero debate entre idéias ser tristemente finalizado pelo argumento "mas isso foi cientificamente comprovado"? Reforçando concepções desse tipo, vêem-se corriqueiramente manchetes em jornais, telejornais e revistas, cujo público-alvo é o mais variado possível, anunciando a mais recente "prova" científica. Professores e alunos, imersos nesse repertório cultural, interagem acriticamente com uma história distorcida da ciência presente na maioria dos materiais didáticos. Mas como poderia ser diferente? Enquanto não lhes for possível conhecer distintos pontos de vista, como esperar que concepções ingênuas sobre a natureza da ciência sejam identificadas e, ainda, problematizadas?

As pesquisas educacionais, como as empreendidas por Lederman (2007), vêm reforçando a importância de questionar a concepção de ciência como puramente empíricoindutivista na escola básica, contrapondo-a com uma reflexão contemporânea sobre o seu funcionamento. Isso implica transformar o conhecimento sobre a natureza da ciência em 
saber escolar. Mas como viabilizar tais conteúdos? Inserir conhecimentos sobre as ciências nas aulas de ciências? Como os professores das disciplinas científicas poderiam lidar com conhecimentos de origem epistemológica?

A literatura especializada aponta a história da ciência como um recurso pedagógico apropriado para abordar a natureza da ciência na sala de aula. Contudo, almejar esses propósitos pedagógicos impõe lidar com diversas dificuldades. As versões distorcidas da história da ciência presentes em materiais didáticos, a falta de formação do professor e a ausência de materiais adequados para o ensino médio, por exemplo, têm sido apontados como alguns dos problemas existentes para o uso da história e filosofia da ciência na sala de aula.

Educadores e reformadores de currículos de vários países têm insistido no desenvolvimento de pesquisas e propostas educacionais que procurem introduzir discussões sobre a natureza do conhecimento científico nas aulas de ciências. As características da natureza da ciência recomendadas por tais estudos pretendem apresentar a ciência construída socioculturalmente, influenciada teoricamente, envolvendo a inferência humana, a imaginação e a criatividade.

Aderimos, assim, aos pressupostos das pesquisas em ensino de ciências voltadas para os benefícios pedagógicos proporcionados pelo uso da história da ciência para discutir a dinâmica do fazer científico do ponto de vista contemporâneo.

Desse modo, nossa pesquisa lida com uma questão fundamental na didática das ciências: é possível utilizar a história e a filosofia da ciência em sala de aula de modo a contemplar propósitos pedagógicos sem incorrer em erros ou simplificações excessivas? Quais e como são os desafios e como devem ser enfrentados? Quais as possibilidades de superá-los?

A possibilidade de investigar e detalhar alguns desses desafios permitiria vislumbrar possíveis soluções. Num segundo momento, tais propostas seriam aplicadas em ambiente escolar visando detectar caminhos factíveis, identificar soluções inadequadas e buscar modos de desenvolver soluções apropriadas. Assim, o plano da pesquisa aqui apresentado se assenta sobre dois pilares: o estudo do quadro teórico e uma investigação empírica. 
No âmbito teórico lidamos com os referentes de diferentes campos do saber: a historiografia da história da ciência, a epistemologia da ciência vista sob uma perspectiva educacional e as necessidades didático-pedagógicas do ensino de ciências em nível médio de escolaridade. Apresentamos esse quadro teórico nos dois capítulos iniciais desta tese. Iniciamos com uma revisão bibliográfica sobre os usos da história da ciência na educação científica, pontuando limitações e destacando benefícios de utilizá-la para ensinar sobre a natureza da ciência. Esclarecemos, a seguir, que discutir certas características do fazer científico utilizando sua história implica adotar uma abordagem empírica para a natureza da ciência.

Entretanto, trabalhar com a história da ciência enfocando o caráter humano, social e histórico do conhecimento científico requer respeitar algumas diretrizes postas pela historiografia contemporânea. As reflexões ocorridas ao longo de todo o século XX no âmbito da filosofia, sociologia e história da ciências, e seus desdobramentos nas pesquisas em ensino de ciências, forjaram também as transformações historiográficas e o modo de compreender as ciências e sua história. Discutimos, assim, algumas perspectivas historiográficas e as distorções da história da ciência mais comuns no ensino e os problemas decorrentes na formação dos alunos. Ainda no primeiro capítulo definimos a concepção de natureza da ciência que adotamos e os aspectos selecionados e tratados pela pesquisa.

A sala de aula, por sua vez, impõe requisitos para viabilizar a interação dos alunos com os saberes escolares, almejando uma educação reflexiva, uma formação crítica e que, principalmente, permita ao aluno aprender a aprender. A transformação da natureza da ciência em saber escolar deve respeitar recomendações historiográficas, mas deve contemplar também as necessidades da sala de aula. Encontramos nos processos da transposição didática de Yves Chevallard (1991) um suporte teórico para pensarmos a construção dos saberes escolares, na perspectiva da didática da ciência. Ela nos permitiu refletir sobre o percurso epistemológico dos saberes, desde sua origem no contexto de referência e até seu ingresso no ambiente escolar. O campo disciplinar da história da ciência, contudo, requereu um olhar diferenciado para a transposição.

A especificidade do saber histórico já deixava clara a dificuldade da dessincretização, uma prescrição da transposição didática. A necessidade de transformar o saber histórico em objeto de Saber a Ensinar e Saber Ensinado requer apartar os saberes de 
referência de seu contexto de produção, para ser posteriormente reconstruído de modo a tornar-se viável ao ambiente escolar. Entretanto, o risco de incorrer em anacronismos, quando se busca adaptar ou simplificar demasiadamente os saberes históricos, pode questionar a viabilidade de se falar em "aprendizagens históricas".

A recontextualização da história da ciência ao nível de escolaridade enfocado buscou contemplar prescrições historiográficas, mas assumiu-se que os saberes voltados ao especialista e aqueles adequados ao ambiente escolar possuem funções sociais distintas. Desse modo, a busca pela harmonização das necessidades didático-pedagógicas e histórico-epistemológicas apontadas pelo quadro teórico prevê alguns desafios nas abordagens da história da ciência na educação científica. O estudo que trata da transposição didática da história da ciência foi o tema do segundo capítulo desta tese.

O trabalho empírico empreendido nesta pesquisa procurou investigar como os resultados do quadro teórico materializavam-se na elaboração de uma proposta piloto e na sua aplicação no ambiente escolar. A elaboração dessa proposta passou pela seleção dos conteúdos históricos, a produção de textos para o professor e para os alunos, e a construção de uma seqüência de atividades didáticas. O desenvolvimento de toda a parte empírica da pesquisa foi descrito no terceiro capítulo. Retomamos nossos objetivos e discutimos a adequação da metodologia qualitativa no planejamento, coleta e análise dos dados. Apresentamos a arquitetura da elaboração do curso piloto, os pressupostos adotados para a criação dos materiais didáticos, as conjecturas feitas para elaborar as atividades didáticas e a preparação da professora que o aplicou.

Essas etapas puderam ampliar, precisar e exemplificar os desafios previstos pela dimensão teórica. Vivenciá-los na construção do curso piloto permitiu-nos propor sua separação entre obstáculos superáveis e contornáveis em função das soluções possíveis para seu enfrentamento, no contexto do nosso trabalho. Essas propostas configuram-se como os primeiros resultados obtidos. A descrição dos obstáculos enfrentados e das soluções aventadas para cada um deles inicia o quarto capítulo.

As propostas conjecturadas na primeira etapa da investigação empírica foram confrontadas com a análise da aplicação do curso na sala de aula. A coleta dos dados deuse mediante prescrições da metodologia qualitativa de análise a partir de fontes distintas: as respostas aos questionários escritas pelos alunos, as transcrições das aulas gravadas em vídeos e anotações de campo realizadas pela pesquisadora. A confluência entre os 
resultados advindos da elaboração do curso piloto e a análise dos dados coletados em campo foram feitas no quarto capítulo.

Acompanhar a aplicação do curso piloto foi um processo rico sob vários aspectos. Pudemos perceber alguns momentos de conflito nos alunos entre as concepções ingênuas sobre a natureza da ciência e o novo enfoque apresentado. Foi uma satisfação compartilhar os momentos de estranhamento, descoberta e perceber indícios do contentamento gerado a cada novo entendimento. As provocações realizadas pelo conteúdo articulado em atividades didáticas obtiveram respostas surpreendentes e criativas por parte dos alunos. A presença próxima a todo o processo nos permitiu, também, detectar limitações nas soluções propostas e, algumas vezes, foi possível orientar a professora na retomada de pontos críticos ou relevantes nas aulas seguintes.

Selecionamos, para uma análise detalhada, três eventos (episódios de ensino) que confrontavam as soluções propostas para o enfrentamento dos obstáculos às relações estabelecidas entre alunos, professora e saber. Ainda no quarto capítulo, apresentamos alguns resultados e pontuamos aspectos relevantes para pensar o uso da história para discutir a construção da ciência.

Durante a análise dos dados detectamos limitações no planejamento do curso piloto, no material didático ou na preparação da professora que nos permitiram realizar pequenas modificações e apresentar uma versão já incorporando alguns redimensionamentos. Esse trabalho concomitante foi muito interessante, pois houve sinergia entre tais processos. Conforme percebíamos pontos do curso piloto que podiam ser mais bem explorados ou redimensionados, em decorrência do contato com os dados, fazíamos algumas adaptações nos textos dos alunos e no planejamento das atividades. Por outro lado, ao refletirmos sobre aspectos conceituais durante a revisão dos textos piloto, ou sobre possíveis alterações em algumas atividades, percebíamos certos detalhes interessantes a procurar nos dados. Pudemos realizar algumas alterações nos textos do curso piloto e apresentar uma versão preliminar do curso, a ser ainda aperfeiçoado. Ambas as versões podem ser encontradas nos apêndices desta tese, incluindo os slides preparados para as aulas e o material didático para algumas atividades.

O recorte estabelecido para nosso objeto de análise tangenciou e excluiu possibilidades frutíferas de investigação. Algumas delas estão pontuadas ao longo desta tese e são apresentadas na conclusão como desdobramentos almejados desta pesquisa. 
As questões da pesquisa obtiveram perspectivas e possibilidades a partir da análise e da reflexão crítica do processo como um todo, apontando para algumas conclusões. Passíveis de generalização, algumas das propostas para superar e contornar os obstáculos enfrentados apontam para estratégias viáveis em contextos semelhantes ao enfocado por esta pesquisa. Buscamos organizá-las como possíveis guias para auxiliar pesquisas voltadas à utilização da história e filosofia da ciência na educação científica. Apresentadas na conclusão desta tese, tais etapas podem ser tomadas por parâmetros iniciais para nortear a transposição didática da história da ciência ao ensino médio na perspectiva de transformar a natureza da ciência em saber escolar. 


\section{O ensino, a história e a natureza da ciência}

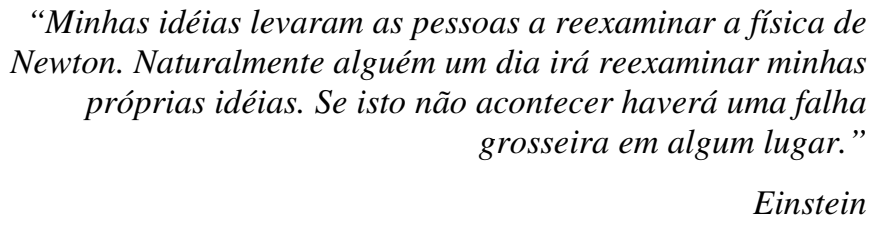

\subsection{O saber historicamente construído}

A compreensão da ciência como uma atividade humana tem sido um objetivo amplamente tratado nas pesquisas em educação científica. Tais estudos reconhecem a relevância de compreendê-la como um corpo de conhecimentos historicamente construído, imerso no contexto cultural de cada época e de cada povo. Conhecer sobre as ciências e não apenas os conteúdos científicos, mas também seus pressupostos, limites de validade e influências contextuais, permite criticar o dogmatismo geralmente presente no ensino de ciências, além de promover o pensamento reflexivo e crítico. Nesse sentido, aspectos sobre a construção do conhecimento científico podem ser revelados pelo contexto histórico no qual eles tenham sido desenvolvidos (MEDEIROs e BEZERRA FILHO, 2000).

A introdução da história da ciência tem sido recomendada na educação científica, pelo menos desde o início do século XX, como estratégia pedagógica que permite alcançar diversos propósitos formativos (LEDERMAN, 2007). Há ampla bibliografia que aponta vários objetivos educacionais propiciados pela interface gerada entre a ciência e sua história. ${ }^{1}$ A história da ciência pode ampliar a cultura geral do aluno, admitindo-se que há valor intrínseco em compreender certos episódios fundamentais que ocorreram na história. Adequadamente contextualizada, a história da ciência permite uma reflexão crítica sobre a ciência como um produto dinâmico do conhecimento humano, criado por indivíduos em dado contexto cultural e histórico, revelando a face humana da ciência. Abordar a dimensão filosófica da história da ciência pode contribuir para a formação do professor de uma disciplina científica, pois sua prática educativa transmite os resultados de uma área

\footnotetext{
${ }^{1}$ Veja, por exemplo, Allchin (2006); Batista (2007); Bizzo (1991); Brush (1989); Carvalho e Castro (1992); Chen (2006); Cupani e Pietrocola (2002); El Hani (2006); Gagliardi (1988); Hanuscin et al. (2006); Holton (2003); Martins, A., (2007); Martins, R., (1990); Matthews (1997); McComas et al. (1998); Niaz (2001); Peduzzi (2001); Pietrocola (2003); Silva (2006); Vannucchi (1996); Whitaker (1979).
} 
permeados por uma concepção sobre a natureza da ciência. As relações entre a história da ciência e a história, por exemplo, proporcionam uma compreensão das relações entre a ciência e o poder, estudando como os interesses políticos de cada governo afetam o fazer científico de sua época. Tal análise possibilita mostrar aos alunos que a ciência não é uma atividade neutra. Os autores apontam ainda que a história da ciência é um recurso que permite discutir criticamente a concepção de verdade absoluta na ciência, estabelecida pelo método empírico. Além disso, estudar a gênese de uma lei científica favorece seu aprendizado significativo, e não apenas entendê-la como mera ferramenta na resolução de problemas. Conhecer a evolução das idéias e os caminhos metodológicos da ciência facilita conhecer os processos interdisciplinares da construção de explicações.

Apesar de existirem vários aspectos positivos no uso da história da ciência no ensino de ciências, revisões bibliográficas recentes (BELL et al., 2001; FORATO et al., 2008) revelam que a sua utilização para discutir aspectos da natureza da ciência tem recebido grande ênfase nas pesquisas educacionais. Isso porque tratar esse aspecto é um componente central da educação científica e fundamental ao letramento científico ${ }^{2}$ (BATISTA, 2007; LEDERMAN, 2007; EL HANI, 2006). Abordagens histórico-epistemológicas vêm sendo apontadas como estratégia pedagógica que permite desenvolver uma visão crítica do fazer científico, mostrando que a ciência não é uma construção puramente racional, desenvolvida por um suposto "método científico" a partir de observações, experimentos, deduções e induções logicamente fundados. Basicamente, essa crítica traz implicitamente como contraponto a ciência como uma construção humana sujeita ao seu contexto sociocultural de desenvolvimento (GIL PEREZ et al., 2001; MCCOMAS et al., 1998; Pietrocola, 2003; Pumfrey, 1991).

Além dos Parâmetros Curriculares Nacionais (BRASIL, 2002), vários projetos e documentos internacionais de reforma educacional das últimas décadas (por exemplo, os citados por Pumfrey, 1991: AAAS, 1990; NCC, 1988; NRC, 1996) confirmam essa tendência, com a implantação da história da ciência no ensino de ciências, enfatizando a necessidade de uma abordagem contextual que visa envolver os estudantes na temática da natureza da ciência (Lederman, 2007; Pumfrey, 1991). Pumfrey (1991) realizou uma análise da reforma britânica ocorrida no final da década de 1980 e mencionou projetos a

\footnotetext{
${ }^{2}$ No original: scientific literacy (LEDERMAN, 2007, p. 831).
} 
esse respeito destacando países como EUA, Holanda, Países Escandinavos e Inglaterra. Lederman (2007) apontou a grande ênfase dada à necessidade de ensinar a natureza da ciência em pesquisas educacionais e reformas curriculares nacionais (Austrália, Canadá, África do Sul, Reino Unido e EUA). O autor discutiu projetos, tendências, problemáticas, desafios e confirmou a grande preocupação que diversas instâncias da educação em ciências têm dedicado ao ensino da natureza da ciência nas últimas décadas.

- Dentre as tendências, ele destaca alguns pontos:

- Entender a ciência se desenvolvendo em um contexto cultural, de relações humanas, dilemas profissionais e necessidades econômicas. Uma ciência parcial e falível, contestável, uma construção cultural.

- Possibilitar certo conhecimento metodológico como um antídoto à interpretação empírico-indutivista da ciência, permitindo refletir sobre as relações e diferenças entre observação e hipóteses, leis e explicações e, principalmente, resultados experimentais e explicação teórica.

- Ampliar o controle democrático da atividade científica, pois, em princípio, exercer a cidadania é decidir sobre o tipo de ciência a ser buscada. Preparar o aluno para compreender os termos que envolvem o debate científico e a ciência como parte de sua cultura envolvendo julgamentos de valor.

No Brasil a história da ciência é recomendada pelos Parâmetros Curriculares Nacionais para o Ensino Médio - PCNEM (BRASIL, 2002a), que permeiam o ensino da biologia, física, química e matemática, destacando a idéia da construção social da ciência, por exemplo:

A história da Química, como parte do conhecimento socialmente produzido, deve permear todo o ensino de Química, possibilitando ao aluno a compreensão do processo de elaboração desse conhecimento, com seus avanços, erros e conflitos. (BRASIL, 2002a, p. 240).

As Orientações Educacionais Complementares aos Parâmetros Curriculares Nacionais (BRASIL, 2002b) destacam a importância da contextualização histórica para o desenvolvimento das habilidades e competências nas aulas de física, química e biologia (BRASIL, 2002b, p. 14-32, 62, 67), além de enfatizar a abordagem histórica dos conhecimentos matemáticos (BRASIL, 2002b, p. 111, 117-118). De modo geral, a história 
da ciência aparece nos temas estruturadores do trabalho pedagógico para $\mathrm{o}$ desenvolvimento das competências possibilitando ao aluno:

Compreender o conhecimento científico e o tecnológico como resultados de uma construção humana, inseridos em um processo histórico e social. (BRASIL, 2002b, p. 32).

A utilização da história da ciência surge, assim, da organização das atividades escolares, por exemplo, nos modelos de constituição da matéria em química (BRASIL, 2002b, p. 93-94, 96), na origem da vida em biologia (BRASIL, 2002b, p. 50-51) ou na origem do Universo em física (BRASIL, 2002b, p. 71, 78-79). Além disso, permite compreender a ciência como cultura, destacando as inúmeras interações entre conhecimento científico e vida social (BRASIL, 2002b, p. 85).

Além dos documentos governamentais de reforma educacional de vários países, há ampla bibliografia de pesquisas educacionais defendendo a pertinência e a importância de levar aos alunos conhecimentos sobre a natureza da ciência (BATISTA, 2007).

Lederman (2007, p. 872) considera que um argumento sempre válido (em diferentes períodos e contextos) para ensinarmos a natureza da ciência é permitir ao aluno conceber a ciência como um campo de estudo. Tal compreensão fornece um contexto significativo para a construção do conhecimento científico. Para ele o ensino da natureza da ciência é defensável na medida em que sua contribuição educacional não é ser apenas algo concreto de valor instrumental, mas algo inerente à própria ciência. Entendemos que para o complexo processo de construção da ciência concorrem diversos fatores de um intrincado ambiente cultural, e não apenas aqueles normalmente considerados científicos. Compreender o desenvolvimento da ciência em seu contexto permite entendê-la como um campo de estudos humanizado. A utilização de análises histórico-epistemológicas tratando de alguns aspectos da natureza da ciência na educação científica facilita essa compreensão.

Conforme Martins (2001) destaca, uma abordagem adequada e crítica da história da ciência requer um objeto de estudo delimitado, bem como os objetivos para os quais se destina. Desse modo, esta pesquisa selecionou como objetivo específico a utilização da história da ciência em ambiente escolar com a finalidade de discutir a natureza da ciência. Assim, dentre as possibilidades apontadas pela literatura educacional, e já mencionadas anteriormente, a opção dessa interface volta-se para: a história da ciência é um recurso 
que permite discutir criticamente a concepção de verdade absoluta na ciência, estabelecida pelo método empírico. Entretanto, há que se explicitar que tipo de abordagem será dada para a natureza da ciência e qual sua relação com a história.

\subsection{A natureza da ciência na educação científica}

Entender a ciência como um saber historicamente construído implica certa concepção sobre o modo como ocorre a elaboração desse saber, ou seja, uma visão específica de aspectos epistemológicos do fazer científico. A opção desta pesquisa por discuti-los volta-se aos aspectos que permitem criticar a existência de um método empírico universal, ou, ainda, uma visão empírico-indutivista da ciência (PIETROCOLA, 2003). Entretanto, existe mais de um tipo de abordagem possível sobre a natureza da ciência, e cada um deles considera distintos aspectos do fazer científico (MARTINS, 1999). Faz-se necessário, portanto, esclarecer, dentre as diversas possibilidades, que enfoque será dado para a natureza da ciência e, além disso, quais aspectos serão privilegiados. Desse modo, serão apresentados a seguir: (i) abordagens possíveis acerca da natureza da ciência; (ii) a opção adotada neste trabalho; (iii) que visão de natureza da ciência os educadores defendem como pertinentes ao ensino; e (iv) os aspectos da natureza da ciência que foram selecionados para esta pesquisa.

\subsubsection{Abordagens possíveis acerca da natureza da ciência}

Segundo Martins (1999) a natureza da ciência pode ser enfocada sob diferentes perspectivas, tanto filosóficas como históricas ou sociológicas. Essa distinção pode ser estabelecida pensando nas questões que podem ser propostas e no tipo de respostas que elas receberão, ou seja, respostas com uma abordagem empírica, normativa (axiológica) ou analítica. As abordagens normativas e analíticas pertencem ao âmbito da filosofia, enquanto a abordagem empírica é tratada pela história e sociologia da ciência.

Uma resposta a uma questão de tipo empírico será fundamentada pela documentação histórica e buscará analisar o que tem sido historicamente a ciência. Martins (1999) considera que as práticas científicas mudam ao longo do tempo e diferem nas diversas disciplinas científicas. Portanto, essa abordagem é tratada por disciplinas metacientíficas, como a história da ciência ou a sociologia da ciência, que investigam, estudam e analisam os fatos, as descrições do que tem sido considerado ciência ao longo 
dos tempos. Esse tipo de análise histórica trata de certas características da natureza da ciência enquanto fato histórico e social, e não sob o ponto de vista filosófico.

Um enfoque bastante diferente é o tratado na perspectiva da filosofia. Uma resposta de tipo normativa remete à avaliação dos procedimentos ou resultados da pesquisa científica. Tal enfoque, também conhecido como axiológico, pressupõe o julgamento de valores e busca avaliar o que é correto e o que é errado na prática científica. Essa resposta pode enfocar aspectos internos ou externos à prática científica, mas não deve basear-se em fatos históricos. Por exemplo, utilizando um critério de valor social externo à ciência, buscaríamos responder a "como deveria ser a ciência para beneficiar a humanidade?", enquanto uma questão metodológica interna à ciência perguntaria: "como a ciência deveria ser para permitir um melhor conhecimento da natureza”? (MARTINS, 1999, p. 7).

Ainda no campo da filosofia, temos a terceira resposta possível de tipo analítico, no sentido do que pode ou do que não pode ser a ciência. Tal abordagem ainda pressupõe uma subdivisão, que apresenta três questões: “Quais concepções de ciência já existiram? Quais concepções de ciência que se pode inventar? O que é filosoficamente possível na ciência, sob o ponto de vista da capacidade do conhecimento humano?" (MARTINS, 1999).

Embora tais análises, de tipo normativo/axiológico e analítico, ofereçam importantes contribuições, no sentido de orientar e avaliar pesquisas, aumentando o valor científico de cada estudo, elas não se configuram como abordagens adequadas aos propósitos educacionais desta pesquisa. Pretende-se tratar aqui os aspectos da natureza da ciência que permitem refletir sobre o que tem sido a prática científica e que favorecem discutir a dimensão cultural e temporal da ciência no ambiente escolar. Portanto, das abordagens sobre a natureza da ciência apresentadas por Martins (1999), aquela que atende aos propósitos educacionais do trabalho é a que faz a discussão de tipo empírico, baseada em análises históricas de episódios científicos.

Uma narrativa histórica diacrônica adequada permite problematizar a visão da ciência como uma construção puramente racional, desenvolvida por um suposto "método científico universal" a partir de observações, experimentos, deduções e induções logicamente fundados. Entendemos essa contribuição como bastante relevante, pois, em geral, no ensino de ciências tem prevalecido o domínio da concepção lógico-positivista da ciência, segundo a qual o conhecimento seria estabelecido pelo "supostamente infalível método empírico" (PIETROCOLA, 2003, p. 133). 
Nas análises de ensino/aprendizagem, segundo Pietrocola (2003), é imprescindível refletir sobre o conhecimento que se espera levar aos alunos. Uma imagem distorcida e estereotipada do conhecimento científico permeia as ações no ensino, perpetuando assim uma visão também deturpada sobre a natureza da ciência. A ciência escolar tem, em geral, apresentado os conceitos científicos como partes inerentes à realidade, desconsiderando os complexos processos históricos envolvidos na tarefa do cientista em buscar interpretar e descrever o mundo natural (PIETROCOLA, 2003, p. 134-135).

Nossa pesquisa volta-se, portanto, para aspectos histórico-epistemológicos da ciência, respaldados pela abordagem empírica da natureza da ciência, ou seja, valendo-se da documentação histórica. Entretanto, viabilizar tal interface buscando conciliar aspectos de diferentes campos do saber implica enfrentar inúmeros desafios.

\subsubsection{Riscos inerentes à distorção histórico-epistemológica}

A utilização da história da ciência como conteúdo escolar, embora considerada potencialmente formativa para a educação científica básica, não está livre de críticas quanto aos riscos de distorção quando aplicada em sala de aula. Inúmeros educadores, filósofos e historiadores da ciência apontam problemas e riscos dessa interface (ALLCHIN, 2006, 2004; Holton, 2003; Martins, A., 2007; Martins, R., 2001, 1990; MAtThews, 1995; Medeiros e BeZerRa, 2000; PeduZzi, 2001; Pietrocola, 2003; VANUCCHI, 1996).

Thomas Kuhn (1997) adverte sobre o tipo de história da ciência normalmente presente nos manuais científicos e outros tipos de literatura deles derivada, que são utilizados no ensino de ciências e objetivam perpetuar a ciência normal. ${ }^{3}$

[Tais veículos] referem-se a um corpo já articulado de problemas, dados e teorias e muito freqüentemente ao conjunto particular de paradigmas aceitos pela comunidade científica na época em que esses textos foram escritos. [...] Para preencher sua função não é necessário que proporcionem informações autênticas a respeito do modo pelo qual essas bases foram inicialmente reconhecidas e posteriormente adotadas pela profissão. Pelo menos no caso dos manuais, existem até mesmo boas

\footnotetext{
${ }^{3}$ Kuhn (1997, p. 173-181). Este capítulo do livro de Kuhn traz a argumentação das razões que contribuem para a visão linear e acumulativa da história da ciência e alguns problemas dela decorrentes.
} 
razões para que sejam sistematicamente enganadores nesses assuntos. (KUHN, 1997, p. 174).

Para Kuhn, a ciência amadurecida retratada nos manuais não contempla a relação da pesquisa científica com seu contexto histórico e omite o processo complexo dos episódios mais significativos do desenvolvimento científico.

Os manuais começam truncando a compreensão do cientista a respeito da história de sua própria disciplina e, em seguida, fornecem um substituto para aquilo que eliminaram. [...] Através dessas referências, tanto estudantes como profissionais sentem-se participando de uma longa tradição histórica. Contudo, a tradição derivada dos manuais, da qual os cientistas sentem-se participantes, jamais existiu. (KUHN, 1997, p. 175).

Os fatos selecionados e distorcidos do passado sugerem que aqueles cientistas estavam trabalhando no mesmo conjunto de problemas mediante o mesmo conjunto de cânones estáveis. Essa articulação reforça a visão de uma ciência cumulativa. Ao tornarem o desenvolvimento da ciência linear, esses relatos escondem o processo "que está na raiz dos episódios mais significativos do desenvolvimento científico" (KUHN, 1997, p. 178).

Os manuais, por visarem familiarizar rapidamente o estudante com o que a comunidade científica contemporânea julga conhecer, examinam as várias experiências, conceitos, leis e teorias da ciência normal em vigor tão isolada e sucessivamente quanto possível. Enquanto pedagogia, essa técnica de apresentação está acima de qualquer crítica. [...] Mas não é assim que a ciência se desenvolve. (KUHN, 1997, p. 178).

Embora Kuhn reconheça o valor pedagógico da reconstrução histórica de episódios da pesquisa científica, ele enfatiza que "o erro histórico faz com que especialistas e leigos se iludam a respeito da natureza do empreendimento científico" (KUHN, 1997, p. 180). A conseqüência imediata desse tipo de distorção histórica no ensino de ciências é a imagem da ciência fomentada na visão dos estudantes.

O que não é trivial é a imagem de ciência fomentada quando esse tipo de erro é articulado e então integrado na estrutura técnica do texto. (KUHN, 1997, p. 180). 
As ponderações de Kuhn apontam para a complexidade da dicotomia entre a ciência "normal" ensinada pela reconstrução histórica e as distorções ocasionadas acerca da natureza da ciência (BIZzo, 1991, p. 149-151; MATthews, 1989, p. 7; PEDUZZI, 2001, p. 152-157).

Parece-nos possível apreender, a partir das considerações de Kuhn, que ele não se opõe à utilização da história da ciência no ensino, mas condena a visão distorcida acerca da natureza da ciência que uma reconstrução malfeita do processo histórico fatalmente traz.

Existe, no entanto, um conjunto de pensadores que defende o uso das reconstruções racionais da história da ciência no ensino, argumentando que ela tanto favorece a compreensão de conceitos, como perpetua a visão robusta da ciência. Segundo Allchin (2004, p. 183), tais autores defendem que retratar os erros e as interpretações alternativas poderia ameaçar a legitimidade do resultado final e conseqüentemente a autoridade última da ciência.

Em oposição a uma reconstrução racional, Whitaker (1979) critica as distorções presentes nos materiais didáticos, denominando-as quasi-history, em que seções históricas incluem erros sobre fatos científicos. Algumas vezes, os episódios históricos são reconstruídos em um encadeamento lógico de como teriam sido elaborados ou descobertos alguns conceitos científicos. Tais reconstruções acabam fornecendo simples moldura histórica, em que realizações científicas ganham sentido e são facilmente relembradas. A construção desse tipo de narrativa da história da ciência poderia ser decorrente do uso da história com o objetivo de ensinar conceitos das ciências e traz implícita a ideologia científica dos autores de livros didáticos e sua visão sobre a natureza da ciência. Essa posição é endossada por Allchin $(2004,2006)$ e Martins (2001), que apontam como um problema, decorrente desse tipo de reconstrução histórica, o fato de se transmitir a falsa impressão de que as idéias emergem do mesmo modo logicamente encadeado no contexto científico.

A preocupação apontada pela literatura que critica as distorções da história presentes nos materiais didáticos vai muito além de simplesmente obedecer a um preciosismo histórico em si. É bem verdade que as narrativas históricas adequadas ao ensino não se configuram em pesquisas voltadas à comunidade de historiadores da ciência. Entretanto, considerar as necessárias adaptações ao ambiente escolar não significa aceitar a construção de narrativas distorcidas dos fatos. A distorção da história não é inócua como 
pode parecer, pois sua conseqüiência imediata permeia a concepção de ciência presente na formação dos alunos e professores de ciência. Apresentamos a seguir alguns tipos de narrativas consideradas atualmente problemáticas e as visões que permeiam cada uma delas.

\title{
1.2.3. Historiografia e ensino de ciências
}

\subsubsection{Diferentes perspectivas e transformações historiográficas}

A historiografia pode ser considerada uma arte: a arte de utilizar com destreza os instrumentos metodológicos apropriados para escrever sobre a história (da ciência).

\begin{abstract}
Pode-se chamar de "historiografia" a produção dos historiadores, para diferenciá-la da "história" - entendida como um conjunto de situações e acontecimentos pertencentes a uma época e a uma região -, que é o objeto de estudo dos historiadores. Temos assim dois níveis distintos. Pode-se considerar que a história existe independentemente da existência dos historiadores (a menos que se adote uma postura filosófica idealista). (MARTINS, 2004, p. 115)
\end{abstract}

A reflexão sobre a atividade dos historiadores também é usualmente denominada de historiografia, mas, por tratar-se de um terceiro nível, pode ser chamada de "metahistoriografia" (MARTINS, 2004, p. 116). Interessa-nos tratar aqui de certas características de diferentes narrativas da história da ciência, e como isso pode interessar ao ensino de ciências. Discutiremos alguns aspectos do que descrevemos acima como historiografia no segundo e terceiro níveis, mas, para os objetivos aqui pretendidos, não é necessário diferenciar cada detalhe da historiografia e da meta-historiografia que analisaremos. Assim, adotaremos a classificação "historiografia" tanto para as narrativas da história da ciência produzida pelos historiadores, como para as reflexões que faremos a respeito dessa produção. ${ }^{4}$

Como todo campo de conhecimento humano, a historiografia da história da ciência desenvolve-se em contextos culturais, sofrendo influência de aspectos diversos que

\footnotetext{
${ }^{4}$ De fato, tal discussão é complexa e foge ao escopo de nossa discussão e pode ser encontrada em Martins (2004).
} 
permeiam o mundo do especialista. Sendo uma construção humana, portanto dinâmica e complexa, ela muda com o tempo e com as transformações culturais.

O modo de escrever sobre a história da ciência passou por grandes transformações ao longo do século XX. Decorrente de um "processo gradual de amadurecimento, de sofisticação, de críticas e contracríticas, a história da ciência deixou de ser uma atividade amadora (no mau sentido) e se tornou um trabalho especializado" (MARTINS, 2001, p. 114). Fundamentais para esse processo foram as reflexões e questionamentos que se intensificaram nas áreas da filosofia e sociologia da ciência, no campo da história e da própria ciência, modificando a maneira de entender a construção do conhecimento científico científico, e estruturando as diferentes perspectivas historiográficas que surgiam no século XX (CANGUilhem, 1977; Debus, 1991; KraGH, 1987; KoYRÉ, 1982; MARTINS, 2004; RossI, 2000).

Nas décadas de 1930 e 1940, intensificaram-se as mudanças na compreensão sobre a ciência feita no Renascimento e nos séculos seguintes, inclusive sobre a influência que o humanismo renascentista teve na medicina e nas demais ciências, incluindo considerar uma concepção mística da natureza. A descoberta de inúmeros manuscritos, que ligavam o estudo da natureza ao neoplatonismo presente no pensamento de diversos filósofos, provocou um novo olhar sobre o nascimento da ciência moderna (DEBUS, 1996; MCGUIRE e RATTANSI, 1966; Rossi, 2000).

Grande quantidade de manuscritos newtonianos foi encontrada na década de 1930 versando sobre alquimia, hermetismo, teologia e doutrinas místicas. Tais abordagens não apenas exigiram, mas também possibilitaram uma releitura do legado de Isaac Newton (1642-1727). Diferentes interpretações que surgiram sobre suas realizações passaram a considerar a influência de elementos culturais de sua época em suas investigações em filosofia natural (DEBUS, 1996; ForATO, 2006). Esse novo olhar sobre a doutrina newtoniana foi outro fator que contribuiu para as transformações na historiografia da história da ciência (KOYRÉ, 1982).

Além dos trabalhos que discutiam influências místicas renascentistas na filosofia natural, surgiram abordagens como a de Boris Hessen $(1985,1992)$, apresentada durante o Segundo Congresso Internacional de História da Ciência (Londres, 1931), que trazia uma interpretação marxista para o "fazer científico", ou seja, a ciência sendo produzida e 
conduzida por fatores sociais. ${ }^{5}$ Hessen propôs uma leitura em que a ciência de Newton teria sido influenciada por elementos socioeconômicos de sua época. A influência de Hessen, e de outros historiadores marxistas, contribuiu para abordagens sociológicas da construção da ciência presentes nas transformações historiográficas (Boss, 1972; RATTANSI, 1988).

Esse complexo processo reforçava a necessidade de um estudo contextualizado da documentação histórica e considerava rupturas na "evolução" da ciência, a influência de fatores sociais, a interferência de valores pessoais dos homens da ciência, e a contribuição dada por antigas tradições - por exemplo, pela alquimia e por certas filosofias místicas -, além de debates entre filósofos da ciência que foram modificando o modo de construir as narrativas históricas (Debus, 1996; DobBs, 1991; Field e JAMES, 1993; FlaUVEL et al., 1988; RossI, 1992, 2000). Importantes reflexões sobre a influência de outras culturas no pensamento ocidental - por exemplo, da cultura chinesa, indiana, babilônica e árabe deram significativas contribuições ao processo, questionando o surgimento da filosofia ocidental unicamente como uma contribuição grega e a construção da ciência como exclusivamente eurocêntrica (LlOYD, 1992; NEEDHAM, 1978; ROCHBERG et al., 1992). A diferente perspectiva que se estruturava enfatizava a necessidade de os documentos serem analisados à luz de sua própria cultura e, na medida do possível, valendo-se de campos correlatos, como a sociologia, a antropologia, a psicologia e a filosofia da ciência (DEBUS, 1991).

\subsubsection{Narrativas históricas no ambiente escolar}

Essas transformações na historiografia da história da ciência deram-se ao longo de quase um século. Entretanto, ainda hoje é muito comum encontrarmos narrativas da história da ciência condizentes com a metodologia historiográfica do início do século XX. Não apenas em materiais de divulgação científica, mas na maioria dos livros didáticos, encontramos abordagens superadas sobre a história da ciência. Segundo as pesquisas em ensino de ciências, o problema decorrente dessas versões distorcidas é o impacto que isso fatalmente tem na formação dos alunos. Ainda que não intencionalmente, uma falsa história transmite uma falsa visão sobre a natureza da ciência (ALLCHIN, 2004; 2006;

\footnotetext{
${ }^{5}$ Existe uma versão em português desse texto: HeSSEN, Boris. "As raízes socioeconômicas dos Principia de Newton”. In: GAMA, Ruy. Ciência e técnica: antologia de textos históricos. São Paulo: T. A. Queiroz, 1992.
} 
Holton, 2003; Martins, A., 2007; MARTins, R., 1990; 2001; 2006; MAtThews, 1995; Medeiros e Bezerra, 2000; Pagliarini, 2007; Pietrocola, 2003; Silva, 2006; WHITAKER, 1979).

Mas como o educador pode lidar com tal desafio? Não se pode esperar que o educador, ou o pesquisador, ou ainda o professor, se transformem em historiadores e filósofos da ciência. Diversas pesquisas educacionais, inclusive, enfatizam que a ampla maioria dos professores não está preparada para lidar com as versões problemáticas da história da ciência (ABD-El-KHAlicK; Gil Perez et al., 2001; Holton, 2003; Lederman, 2000; Martins, A., 2007; McComas et al., 1998; Silva, 2006).

Entretanto, acreditamos que é possível e desejável desenvolver ações que possam apoiá-los em suas pesquisas e em sua prática docente. Holton (2003) e Allchin (2004) enfatizam e recomendam tais iniciativas, não com vistas a formar especialistas nas diversas áreas, mas em fornecer subsídios que possam contribuir para a identificação de distintas narrativas da história da ciência, buscando preparar o não-especialista para interagir de modo crítico com elas.

Gerald Holton (2003) comenta a disparidade entre os trabalhos atuais produzidos pelo historiador da ciência e os relatos presentes na educação científica e enfatiza a necessidade de produzir livros, publicações suplementares, filmes e sites com o objetivo de unir as duas culturas. Allchin (2004) defende que o educador deveria entender as distorções mais comuns, pelo menos por meio de alguns exemplos, para poder reconhecer os sinais de alerta em um texto histórico problemático, que ele denominou Pseudohistory (pseudo-história).

Tomando-se como referência a historiografia atual, alguns aspectos metodológicos consensuais na construção das narrativas da história da ciência, vamos apresentar alguns problemas apontados pelos especialistas que podem auxiliar na identificação dessas abordagens ultrapassadas da história da ciência. É claro que em um período de poucas décadas ocorrem mudanças nas abordagens historiográficas, porém há certos aspectos metodológicos que têm sobrevivido a modismos e radicalismos e desrespeitá-los gera os erros historiográficos mais comuns (MARTINS, 2004). 


\subsubsection{Reconhecendo as distorções históricas}

Há muitos adjetivos para as narrativas que distorcem a história. Do nosso ponto de vista, é possível perceber que há diferenças sutis entre várias dessas denominações, mas, na ampla maioria das vezes, alguns termos costumam ser utilizados como sinônimos. Em geral, uma interpretação de um episódio histórico que apresenta uma abordagem problemática traz vários enfoques que são considerados pela nova historiografia distorções na interpretação dos documentos.

$\mathrm{O}$ anacronismo é erro mais comum. O princípio essencial para historiadores é o respeito pelo contexto histórico. Desrespeitá-lo é interpretar o passado anacronicamente, ou seja, nos termos de normas ou de padrões atuais (Allchin, 2004). Pontos de vista anacrônicos de qualquer fato ou de episódios da história da ciência interpretam e julgam os acontecimentos históricos de um período com valores, idéias e crenças de outra época, ou seja, avaliam o passado de modo preconceituoso, selecionando e enaltecendo conceitos e teorias "similares" aos aceitos no presente. Olhar para o passado com os olhos do presente pode vir tanto de ações ingênuas decorrentes de desconhecimento historiográfico ou de ações que buscam atingir determinados propósitos. Parece-nos mais provável que a grande maioria das versões distorcidas da história da ciência deve-se ao não conhecimento de versões consideradas adequadas pelos especialistas.

Um tipo especial de anacronismo é o whigguismo, que narra os acontecimentos com o propósito de afirmar a autoridade de grandes pensadores. Tal denominação foi inspirada na prática de um partido político na Grã-Bretanha, que moldava a história com a finalidade de substanciar o próprio poder. A história funcionava como um recurso político para legitimar a autoridade. Apagava-se a contingência histórica e a ação das personagens do passado era reconstruída de modo a atingir os propósitos de determinados grupos (Allchin, 2004). O termo whig já era usado por historiadores no início do século XX para caracterizar essa heroificação das instituições inglesas. Na história da ciência ele designa um tipo de história anacrônica que glorifica a genialidade de algumas personagens, em geral, batizadas de pais de inventos e campos de estudo. Tal reconstrução desconsidera a complexidade do fazer científico, como a contribuição dos debates, de erros, de teorias superadas e mesmo de fatores extracientíficos no desenvolvimento da ciência (JARDINE, 2003). A incerteza histórica é suprimida e a narrativa construída anacronicamente apresenta uma teoria tida como predecessora de idéias atuais de modo a glorificar seu 
autor. As versões da história da ciência que buscam atribuir a paternidade a alguns campos de estudo, ou a descobertas, ou a invenções são conhecidas também como história pedigree (ALFONSO-GOLDFARB, 1994).

Allchin (2004) classifica como hagiografia um tipo específico de whigguismo que romantiza certos pensadores da ciência do passado como "heróis", sobrevalorizando aspectos específicos de suas contribuições. A construção do romance que os transforma em heróis santificados enfatiza os aspectos favoráveis da vida deles e suas descobertas e, muitas vezes, descreve seus adversários como vilões. Em sentido amplo, a hagiografia é geralmente definida como a biografia dos santos e mártires, ou de qualquer pessoa idealizada, de modo parcial a favor do biografado. Allchin utiliza esse termo para enfatizar as versões da história da ciência que não apenas "santificam" um pensador "genial", como omite seus erros, desconsidera as contribuições anteriores ou de seus pares e apresenta suas conjecturas como um modelo idealizado de pensamento científico. Naturalmente, o problema não está em admirar pessoas brilhantes, mas fomentar a visão de que a construção da ciência ocorre segundo tais romances.

Outro exemplo de anacronismo é a reconstrução racional de episódios da história da ciência. Embora defendida por alguns pensadores como útil para ensinar conceitos científicos e "necessária" para evitar conflitos com o paradigma vigente, constitui outra distorção da história (ALLCHIN, 2004; WHITAKER, 1979). Em geral, seu autor seleciona em períodos anteriores apenas os fatores que contribuem para uma reconstrução racional das etapas da criação de teorias e conceitos científicos aceitos pela ciência contemporânea. As idéias e os acontecimentos do passado são organizados como se a elaboração de conceitos e teorias seguisse etapas encadeadas logicamente, cujo resultado final seria fatalmente encontrado. Geralmente, esse tipo de anacronismo faz parecer que existe uma receita infalível para produzir a ciência: basta que um infalível gênio excepcional siga consistentemente as etapas de um infalível e único método científico universal.

Em geral, esses problemas são muito comuns em narrativas históricas que tentam descrever um período muito longo ou, ainda, generalizar o ponto de vista de pensadores radicais atribuindo concepções individuais a um período, ou escola de pensamento (MARTINS, 2001). Esses relatos destacam, em geral, fatos encadeados linearmente, desconsiderando rupturas, debates, controvérsias, idéias alternativas e qualquer elemento do contexto cultural que não reforce as idéias que se pretende enfatizar. Tais abordagens 
ignoram a influência de fatores considerados como não científicos pela ciência atual, ainda que certos elementos tenham sido fundamentais em outros períodos. O problema com as narrativas linearizadas é que levam o aluno a crer numa ciência que evolui infalivelmente, guiada por um método universal e descolada de qualquer influência social ou humana.

Essas não são, certamente, versões da história da ciência apropriadas para ensinar sobre a natureza da ciência (ALLCHIN, 2004). As distorções na concepção da construção da ciência podem ser decorrentes de inúmeros fatores presentes em tais versões anacrônicas da história da ciência, em geral repletas de juízos de valor. Whitaker (1979) discutiu vários exemplos e denominou tais narrativas de quasi-history. Allchin (2004) exemplifica também diversos desses problemas e classifica essas interpretações distorcidas de pseudohistória. Ele considera que é importante o pesquisador/educador poder reconhecer a pseudo-história e estar alerta para os seus principais indícios:

- relatos romantizados;

- personagens perfeitas;

- descobertas monumentais e individuais;

- insight tipo eureca;

- apenas experimentos cruciais;

- senso do inevitável, trajetória óbvia;

- retórica da verdade versus ignorância;

- ausência de qualquer erro;

- interpretação aproblemática de evidências;

- simplificação generalizada das evidências;

- conclusões sem influências ideológicas.

Em geral, tais descrições não fazem uma abordagem contextualizada e deixam de mencionar aspectos relevantes, como:

- ambiente cultural ou social;

- contingências humanas;

- idéias antecedentes;

- idéias alternativas;

- aceitação acrítica de novos conceitos. 
Segundo Allchin (2004), esses sinais não são indicativos absolutos, mas alertas para o leitor confrontar interpretações históricas com fontes confiáveis.

Os diferentes tipos de anacronismo, ou a presença de uma interpretação distorcida dos documentos históricos, trazem prejuízos à visão de ciência que tem sido recomendada para a educação científica. Um dos prejuízos dessa concepção é o desestímulo ao pensamento crítico. Aceita-se uma idéia como valorosa, por exemplo, simplesmente por ter sido proposta por uma autoridade genial ou infalível. O propósito de compreender a dimensão humana da ciência como uma construção cultural, apontado pelas inúmeras pesquisas educacionais já discutidas, naturalmente fica comprometido.

\subsubsection{Delimitando a concepção de natureza da ciência}

As visões sobre a natureza da ciência que têm prevalecido na educação científica são concepções distorcidas que transmitem uma imagem empírico-indutivista da ciência, entretanto consolidada e aceita socialmente, que a própria educação científica reforça e ajuda a propagar (PIETROCOLA, 2003).

Gil Perez e colaboradores (2001) realizaram uma análise das opiniões dos professores sobre o trabalho científico, eles as relacionaram e caracterizaram sete visões deformadas da natureza da ciência. Tais visões decorrentes de uma educação científica de mera transmissão de conhecimentos são abundantemente referidas na literatura educacional. A seguir apresentamos breve descrição dessas concepções que Gil Perez e colaboradores (2001) consideram uma imagem ingênua da construção do conhecimento científico, consolidada socialmente, que a própria educação científica propaga ativa ou passivamente:

- concepção empírico-indutivista e ateórica: atribui um papel "neutro" para a observação e a experimentação, não influenciadas por idéias apriorísticas. Desconsidera o papel essencial das hipóteses como orientadoras da investigação, e dos referentes teóricos;

- visão rígida, algorítmica, exata e infalível: defende a existência de um "método científico" como um conjunto de etapas a seguir mecanicamente, mediante um tratamento quantitativo e controle rigoroso, ignorando a criatividade, o caráter tentativo, e a incerteza; 
- visões aproblemática e a-histórica (dogmática, fechada): transmite os conhecimentos já elaborados, sem mostrar os problemas que lhes deram origem, qual foi a sua evolução, as dificuldades encontradas, e omitem as limitações do conhecimento científico atual;

- visão exclusivamente analítica: visão compartimentada da ciência que desconsidera as relações entre diferentes campos do conhecimento;

- visão acumulativa de crescimento linear: a construção do conhecimento científico seria fruto de um crescimento linear, puramente acumulativo, em que não ocorrem crises nem revoluções;

- concepção individualista e elitista: os conhecimentos científicos aparecem como obras de gênios isolados, ignorando-se o papel do trabalho coletivo e cooperativo, e dos intercâmbios entre equipes (visão whig);

- visão socialmente neutra da ciência: desconsidera as complexas relações entre ciência, tecnologia e sociedade e proporciona uma imagem deformada dos cientistas como seres "acima do bem e do mal", fechados em torres de marfim e alheios à necessidade de fazer opções.

Esses itens relacionados por Gil Perez e colaboradores (2001) mostram que a concepção da ciência predominante entre professores de ciência retratam a mesma visão historiográfica anacrônica e problemática transmitida pelas narrativas pseudo-históricas da ciência. Percebe-se, inclusive, que os indícios de uma pseudo-história propostos por Allchin (2004) também se aplicam à imagem sobre a ciência que a pesquisa de Gil Perez e colaboradores (2001) indicou.

É interessante notar que isso poderia nos ajudar a entender, de certo modo, por que é tão difícil para os professores detectar as visões distorcidas da história da ciência. Não é apenas pelo fato de que eles não são historiadores ou filósofos da ciência. Antes disso, as versões históricas introduzidas pelos diferentes materiais e fontes no ambiente escolar reforçam a imagem da ciência que têm prevalecido no ensino, tornando-as faces de uma mesma moeda.

Os estudos de Allchin (2004), Whitaker (1979), Gil Perez e colaboradores (2001) e Pietrocola (2003) mostram que tanto a visão de ciência como a concepção da história da ciência que predominam no ensino retratam os pressupostos teóricos do quadro historiográfico do início do século XX. Essa questão reforça a necessidade de ensinar sobre 
a natureza da ciência. Entretanto, deve-se ter em mente que uma proposta desse tipo não se limita a inserir um novo conteúdo. $\mathrm{O}$ uso da história da ciência no ensino pretende transmitir uma concepção sobre a natureza da ciência que se oponha ao estereótipo presente no contexto educacional.

É necessário estabelecer o que se deve entender como uma visão adequada da natureza da ciência, pois não existe uma concepção única para ela entre os filósofos da ciência. Entretanto, há pontos de concordância entre as distintas visões, apontados por pesquisas educacionais (EL HANI, 2006; GIL PEREZ et al., 2001; MCCOMAS et al., 1998).

McComas et al. (1998), Gil Perez et al. (2001) e El Hani, (2006) reconhecem a existência de um consenso pragmático na literatura especializada com relação aos aspectos da natureza da ciência mais importantes para uma sociedade letrada cientificamente e, portanto, valiosos para constar nos currículos de ciências. Dentro dessa confluência, especialistas selecionam os aspectos epistemológicos que deveriam permear o ensino de ciências e serem debatidos em ambiente escolar (El HANI, 2006; GIL PEREZ et al., 2001; MCCOMAS et al., 1998; PUMFREY, 1991). Os autores trazem uma síntese de uma visão adequada acerca da natureza da ciência que tem sido recomendada em parâmetros curriculares de diversos países. Entender a ciência se desenvolvendo em um contexto cultural, de relações humanas, dilemas profissionais e necessidades econômicas é, segundo Pumfrey (1991), um dos propósitos pedagógicos da utilização de conhecimentos históricoepistemológicos no ensino. Assim, discute-se na presente pesquisa como a história da ciência pode ser utilizada para fomentar uma concepção de ciência em acordo com esses pressupostos. Isso implica também criticar a concepção empírico-indutivista da ciência, que inclui a idéia de verdade absoluta estabelecida pelo método empírico. Dessa forma, busca-se promover uma visão sobre a construção do conhecimento científico como uma atividade humana.

Esta pesquisa enfoca os seguintes aspectos da natureza da ciência, buscando vê-los incorporados no ambiente escolar:

- a natureza não fornece dados suficientemente simples que permitam interpretações sem ambigüidades;

- uma observação significativa não é possível sem uma expectativa preexistente;

- a ciência é uma atividade humana influenciada pelo contexto sociocultural de cada época; 
- teorias científicas não podem ser provadas e não são elaboradas unicamente a partir da experiência;

- o conhecimento científico baseia-se fortemente, mas não inteiramente, na observação, evidência experimental, argumentos racionais e ceticismo.

\subsection{Pressupostos e desafios}

A despeito de ser praticamente consenso na área de ensino de ciências a importância da utilização de conteúdos da história e filosofia da ciência para o ambiente escolar, ainda são muitos os desafios e poucas as propostas concretas (MARTINS, A., 2007). O produto do trabalho dos historiadores da ciência não é adequado para o ensino de ciência, requerendo adaptações. Segundo Gerald Holton (2003), a disparidade entre historiadores da ciência e os educadores em ciências conduz a dificuldades práticas e devese a diversos fatores: preparação profissional; diferentes preocupações e interesses; vários periódicos; diversas sociedades profissionais e os sistemas de premiação. A falta de material adequado também dificulta a interface, pois, em geral, os livros-textos não têm espaço para mais que anedotas históricas. Assim, Holton (2003) enfatiza a necessidade de investimentos em ações concretas para subsidiar o pesquisador/professor com objetivo de unir as duas culturas.

Quando nos voltamos à realidade brasileira, também encontramos educadores defendendo o uso da história da ciência e a necessidade de investimentos em ações concretas (MARTINS, A., 2007; SILVA, 2006). Uma das possibilidades propostas é voltada à produção de material didático, por exemplo:

- É importante produzir material que possa orientar o professor do ensino médio para o uso adequado do enfoque histórico no ensino da ciência como objeto de construção (CASTRO e CARVALHO, 1992, p. 117).

- A crítica geralmente feita ao uso da história da ciência no ensino, normalmente, baseia-se numa história anacrônica e whig, o que fortalece a necessidade de produzir material mediante critérios historiográficos diacrônicos (PIETROCOLA, 2003).

Quando partimos da teoria para a ação, de imediato surgem diversas questões: como adequar os conhecimentos de história e filosofia da ciência ao ambiente escolar? 
Como saber identificar as informações relevantes sem distorcer os episódios? Como retratar com a melhor fidedignidade possível o debate entre teorias, a proposta de novas idéias, a realização de experimentos, para um público não especializado, não familiarizado com a metodologia da história da ciência? Quais aspectos de episódios históricos podem propiciar reflexões sobre a natureza da ciência? Quais tipos de distorção devem ser evitados? Como ser ao mesmo tempo adequado ao aluno e ao professor não-especialista e cuidar para não construir uma pseudo-história?

O desenvolvimento de nossa pesquisa tratou dessas questões buscando oferecer uma contribuição para a utilização da história e filosofia da ciência em ambiente escolar, tanto no âmbito da produção do conhecimento acadêmico, como oferecendo uma proposta de inserção para o ensino médio.

A problemática apresentada neste capítulo delineou o tema da presente pesquisa que adota como ponto de partida os seguintes pressupostos:

- pesquisas em ensino de ciências apontam a importância, a relevância e os propósitos pedagógicos objetivados na inclusão de conhecimentos sobre a natureza da ciência na educação científica;

- a história da ciência é reconhecida como um recurso pedagógico eficaz para realizar uma abordagem empírica da natureza da ciência, além disso, o seu estudo traz implícitos inúmeros benefícios educacionais;

- os materiais produzidos pelo historiador da ciência voltados à sua área especializada são inadequados ao ambiente escolar;

- as narrativas históricas predominantes da educação científica relatam pseudohistórias cujo maior prejuízo é fornecer uma imagem equivocada da construção do conhecimento científico;

- pesquisas em educação científica indicam que a ampla maioria dos professores não está apta a lidar com os diversos tipos de distorções históricas;

- não é possível pretender que o professor se torne historiador ou filósofo da ciência, desse modo, especialistas recomendam a elaboração de materiais adequados ao professor e ao aluno e ações que possam auxiliar o professor a reconhecer e lidar com a pseudo-história. 
Partindo de tais premissas, a presente pesquisa contemplou aspectos da didática das ciências e da historiografia da história das ciências tratando de aspectos epistemológicos. Ao buscar analisar e harmonizar as necessidades desses distintos campos do saber, o estudo desenvolveu-se em dois níveis distintos: no âmbito teórico e empírico. Essa parte empírica consistiu na elaboração, aplicação e análise de uma seqüência didática voltada para a escola básica.

Viabilizar a utilização da história e filosofia da ciência em ambiente escolar requereu lidar com desafios para harmonizar as diferentes necessidades e interesses desses campos do saber. Construir uma abordagem adequada do ponto de vista historiográfico deve levar em conta também as exigências da sala de aula. As reflexões sobre a didática da ciência que fundamentou a adequação dos conhecimentos históricos ao ambiente escolar serão apresentadas no capítulo a seguir. 


\section{Saberes escolares}

"O rio atinge seus objetivos porque aprendeu a contornar obstáculos."

Lao-Tsé

A produção dos saberes escolares para a educação científica envolve processos complexos. Sua organização em níveis de escolarização requer o enfrentamento de questões como seleção de conteúdos, processos de aprendizagem, materiais de ensino, avaliação etc. Tais questões são tratadas pela didática da ciência, que também se preocupa com toda a dimensão envolvida na adequação de conteúdos ao ambiente escolar (VALENTE, 2003). A seleção, escolha de abordagens e nível de aprofundamento e/ou abrangência a ser dado a cada tema específico pressupõe uma fundamentação no projeto pedagógico em que tais reflexões se inserem. No âmbito nacional, os órgãos governamentais propõem um currículo cujo delineamento do conteúdo traz implicitamente um posicionamento político. O mesmo acontece em instâncias regionais, nos níveis estadual, municipal e mesmo no contexto sociocultural mais específico do microambiente em que cada escola se insere.

O processo de adequação de um determinado saber aos condicionantes e possibilidades do sistema de ensino ao qual se destina se inicia já na sua seleção como conteúdo escolar, seja esse saber o conteúdo conceitual de cada disciplina científica, seja a história da construção desses conceitos, ou qualquer outro considerado pertinente ao ensino. Ingenuamente, poder-se-ia pensar em mera redução de dificuldades de saberes acadêmicos ou especializados. Entretanto, o trabalho envolvido na construção desse saber é muito mais complexo. Não se trata de apenas "traduzir" conteúdos ao vocabulário acessível a cada faixa etária, ou meramente produzir exercícios que interessem ao aluno e favoreçam os processos de avaliação. De fato, o processo é muito mais complexo, pois envolve a produção de conhecimentos de outra natureza.

Quando se considera o ensino de ciências, a preocupação é focada, de modo geral, tanto em aspectos conceituais específicos do campo original como na dimensão didáticopedagógica, no sentido de adequação ao ambiente escolar. A construção de um saber adequado ao ensino de ciências não se constitui em mera simplificação do trabalho de cientistas para não especialistas. Segundo Brockington e Pietrocola (2005), as motivações 
e objetivos do ensino de ciências são muito diferentes daqueles presentes no fazer científico. Ocorre uma mudança do nicho epistemológico, da produção do conhecimento no âmbito da pesquisa científica para o ambiente escolar, o que implica uma inevitável transformação do conhecimento. Portanto, é necessário ocorrer a produção de um novo saber, com os riscos inerentes ao processo de criação. Existe um percurso epistemológico que começa na fonte do saber e termina na sala de aula.

A seleção e adequação dos conteúdos oriundos da história da ciência, objeto nesta pesquisa, requer critérios específicos na seleção dos saberes tendo em vista os propósitos pretendidos com o seu uso em ambiente escolar. A abordagem de conteúdos deve cuidar para evitar o risco da pseudo-história (Allchin, 2004) e de outros problemas que fomentam uma visão distorcida da natureza da ciência apontados por especialistas como Kuhn (1997), Allchin (2006), Holton (2003), Pietrocola (2003), Martins (2001) e Whitaker (1979).

Quando se pretende discutir a natureza da ciência utilizando conteúdos históricos, há, ainda, que se considerar os complexos requisitos na abordagem dos aspectos epistemológicos, apresentados e selecionados no capítulo 1 (EL HANI, 2006; GIL PEREZ et al., 2001; LEDERMAN, 2007, PUMFREY, 1991).

Portanto, a viabilização do uso da história da ciência na educação científica para discutir a natureza da ciência impõe considerar as especificidades de saberes e fazeres de distintos campos do conhecimento, buscando harmonizar as necessidades didáticopedagógicas e as histórico-epistemológicas. Desta forma, a problemática envolve compreender as condições da seleção dos saberes escolares, de sua produção e os pressupostos para sua transmissão (GABRIEL, 2001).

No universo das pesquisas no campo da didática das ciências, a Transposição Didática (CHEVALLARD, 1991) trata das transformações sofridas pelos saberes acadêmicos até chegarem ao ambiente escolar. Essa transformação reconhece um distanciamento obrigatório entre esses diferentes saberes, tratados tanto pela nova sociologia do currículo como pelos autores que trabalham a partir do enfoque da epistemologia escolar. Nesse sentido, a transposição didática permite pensar a reelaboração dos saberes, atentando para os riscos de sua banalização e exercendo constante vigilância epistemológica, indispensável a esse tipo de reflexão. Considerar as necessidades didáticas de cada 
disciplina significa respeitar a autonomia epistemológica atribuída ao saber escolar (GABRIEL, 2001).

Desse modo, parece-nos que a Transposição Didática, enquanto abordagem teórica, fornece alguns subsídios para compreender as transformações no percurso epistemológico dos saberes especializados do ambiente de sua produção até sua adequação ao ensino de ciências. Esse conceito, nascido no campo da didática da matemática, tem sido utilizado em distintos campos disciplinares para se pensar a construção dos saberes escolares (GABRIEL, 2001; BRocKington, 2005; RicARdO, 2005; SiQUeIRA, 2006; VALENTE, 2003).

Vamos apresentar a seguir uma síntese de alguns aspectos da Transposição Didática visando esclarecer em que medida ela nos ampara na elaboração de conteúdos da história da ciência para o ambiente escolar.

\subsection{Os processos da construção do saber}

A análise da transposição didática surgiu no início da década de 1980 , dentro do campo da didática das disciplinas, mais especificamente no âmbito da didática da matemática. Esse conceito já estava presente na tese do sociólogo francês Michel Verret (1975), ${ }^{6}$ e foi desenvolvido por Chevallard (1991) no início da década de 1980. A transposição didática tornou-se conhecida inicialmente na área de ensino de matemática devido a um trabalho de Yves Chevallard e Marie-Alberte Johsua (1982, Un exemple d'analyse de la transposition didactique - La notion de distance). Voltado ao ambiente de escolas secundárias francesas, o trabalho analisava um exemplo, então recente e bem específico, do Movimento da Matemática Moderna: as diferenças entre o conceito matemático de "distância" no ambiente acadêmico, quando proposto pelo matemático francês Maurice Fréchet, em 1906, até a sua incorporação, em 1971, ao sistema de ensino fundamental francês (Alves FILHO, 2000, p. 219). Em 1985, Chevallard publicou "La Transposition Didactique", cujo conteúdo era basicamente composto pelas notas elaboradas em 1980 por ele para um curso de verão (CHEVALLARD, 1991, p. 11).

A idéia proposta por Chevallard demonstrou significativo poder de sedução; didatas da matemática e de outros campos disciplinares debruçaram-se sobre ela, tanto para louvála e dela se valer, como para criticá-la. Motivando exposições e seminários, que incluíam

\footnotetext{
${ }^{6}$ Verret, M. Le temps des etudes. Paris: Honoré Champion, 1975.
} 
debates sobre ambigüidades e ambivalências, a transposição didática ultrapassou os muros da matemática e se tornou referencial teórico para diversos campos educacionais (Chevallard, 1991, p. 11; VAlente, 2003, p. 67).

A idéia proposta por Chevallard demonstrou significativo poder de sedução; didatas da matemática e de outros campos disciplinares se debruçaram sobre ela, tanto para louvála e dela se valer, como para criticá-la. Motivando exposições e seminários, e debates sobre ambigüidades e ambivalências, a transposição didática ultrapassou os muros da matemática, tornando-se referencial teórico para diversos campos educacionais (Chevallard, 1991, p. 11; VAlente, 2003, p. 67).

A despeito do grande número de trabalhos que inspirou, não há, consenso sobre diversos aspectos dessa proposta, como por exemplo se ela pode realmente ser considerada uma teoria aplicável às diversas disciplinas escolares (CHEVALLARD, 1991, p. 11; RiCARDO, 2005, p. 166; VALENTE, 2003, p. 63-66). Desse frutífero debate, ocorrido desde sua proposição, decorrem várias reflexões sobre a complexidade dos fatores participantes da elaboração dos saberes que permeiam o ensino. Em resposta às várias criticas e polêmicas recebidas, Chevallard adicionou um posfácio na segunda edição da transposição didática, em 1991.

Não se pretende aqui realizar um estudo amplo do tema. Serão tratados apenas os aspectos relacionados ao nosso problema de pesquisa: a transposição de saberes de natureza epistemológica para o ensino de ciências utilizando a história da ciência como recurso pedagógico. Para isso, deve-se ter em mente os diferentes contextos: a transposição didática foi proposta na década de 1980, a partir da análise de um exemplo específico do Movimento da Matemática Moderna, ambientado a certas escolas francesas "equivalentes" ao ensino fundamental brasileiro. Seria tal conceito aplicável, adequado e pertinente aos conteúdos histórico-filosóficos quase três décadas depois? Na literatura educacional há diferentes opiniões sobre isso. Diversos autores defendem a transposição didática estendida a outros campos disciplinares; há estudiosos que propõem uma apropriação com limitações para cada caso específico, bem como há muitos críticos que vêem nela mais restrições do que benefícios (BROCKINGTON, 2005; ANHORN, 2004; Gabriel, 2001; Leite, 2004; Lima-Tavares; El-Hani, 2001; Marandino, 2004; RICARDO, 2005; SIQUEIRA, 2006; VALENTE, 2003). 
Selecionamos certos aspectos da transposição didática que podem contribuir para entendermos alguns requisitos necessários à adaptação dos saberes da história e filosofia da ciência ao ambiente escolar. Passemos a eles.

\subsubsection{A didática específica como ciência}

A primeira edição da obra "Transposição didática - do Saber Sábio ao Saber Ensinado" (CheVALlard, 1991) foi publicada em 1985. Seu prefácio trazia o texto "Por que a transposição didática?" (1991, p. 11-44) escrito em 1982, e nele, encontramos elementos que nos permitem entender um pouco do contexto que permeou a elaboração da transposição didática.

$\mathrm{O}$ autor, que se inclui nas linhas de pesquisa de viés sociológico, desenvolve o conceito de transposição didática pressupondo que todo sistema de ensino tem seu funcionamento compatível com o ambiente social em que se insere (GABRIEL, 2001; VALENTE, 2003). Chevallard volta sua atenção ao sistema educacional, universo no qual o ensino da matemática está inserido, para ele "o último refúgio dos sonhos, que suporta o peso das expectativas, dos fantasmas e das exigências de toda uma sociedade” (1991, p. 13).

Chevallard (1991, p. 14-15) adota a "didática da matemática" como uma ciência, que possui um objeto real preexistente, independente de nossas intenções e dotado de necessidade e determinismo próprios. Segundo ele, é um objeto cognoscível no sentido em geral dado à atividade científica. Sendo um objeto tecno-cultural, inscrito, portanto, na história, possui um espírito próprio que dificulta a investigação-ação e requer esclarecimentos. Sob uma perspectiva sociológica (no sentido já proposto por Verret, 1975), ele define esse objeto real em relação direta com o sistema didático: um jogo estabelecido entre um docente, os alunos e um saber matemático - a relação didática. Incluindo esse terceiro elemento, o saber - segundo ele, negligenciado por muito tempo pelos estudos em ensino e aprendizagem - , emerge uma questão fundamental: o que é que no sistema didático encontra-se sob o estandarte do Saber? Qual sua origem, filiação e legitimidade? (CHEVALLARD, 1991, p. 15-16).

Surge assim, o que poderíamos chamar de "pedra fundamental" do conceito da transposição didática: a origem e a construção do saber, o objeto da investigação científica. 
[...] O que é então aquele que, no sistema didático, se coloca sob o estandarte do Saber? O "saber ensinado" que concretamente encontra o observador [o didata que analisa o sistema didático], que relação estabelece com o que se proclama fora desse âmbito? E que relação estabelece com o "saber sábio", o dos matemáticos? Que distâncias existem entre uns e outros? Estas perguntas mínimas, sem duvida, tocam um ponto sumamente importante: gênese, filiações, legitimidades, tudo isso mesclado e em forma de debate. Gêneses míticas? Filiações negociadas? Legitimidades incertas? (CHEVALLARD, 1991, p. 15-16).

Nota-se, nesse ponto de partida, duas preocupações centrais:

i) a origem do saber que chega ao ambiente escolar;

ii) a legitimidade desse saber.

A perspectiva da transposição didática centra sua atenção nas modificações sofridas pelo saber até chegar no ambiente escolar. Entretanto, a pertinência dos saberes escolares, sua legitimidade cultural, também mereceu destaque no contexto de elaboração da transposição didática, conforme enfatiza Ricardo (2005, p. 160). Tal fato, parece-nos, corrobora o viés sociológico da transposição didática, entendendo seu objeto de estudo em seu contexto sociocultural.

\subsubsection{Saberes acadêmicos no ensino de ciências}

Entender o sistema didático como um sistema aberto, compatível com o meio no qual se insere, requer compreendê-lo respondendo às exigências que acompanham e justificam o projeto social estabelecido pelo seu contexto (CHEVALLARD, 1991, p. 17). A transposição didática foi pensada em um contexto específico, a partir de um exemplo bem específico, no caso o conceito de distância, tomado da didática da matemática. As questões que se buscou responder foram: Como esse conceito foi tratado durante esse período no ambiente acadêmico? Quais as diferenças entre eles? Quais transformações sofreu?

Neste quadro teórico definem-se três tipos diferentes de saber: o Saber Sábio (produzido nas esferas acadêmicas), o Saber a Ensinar (aquele que chega ao ambiente escolar nos materiais didáticos e programas) e o Saber Ensinado (aquele efetivamente trabalhado em sala de aula) (CHEVALLARD, 1991). 
Chevallard (1991) adota como Saber Sábio aquele construído na esfera acadêmica, desenvolvido no interior das comunidades de pesquisa. No caso das ciências, por exemplo, pelos cientistas e pesquisadores de uma maneira geral.
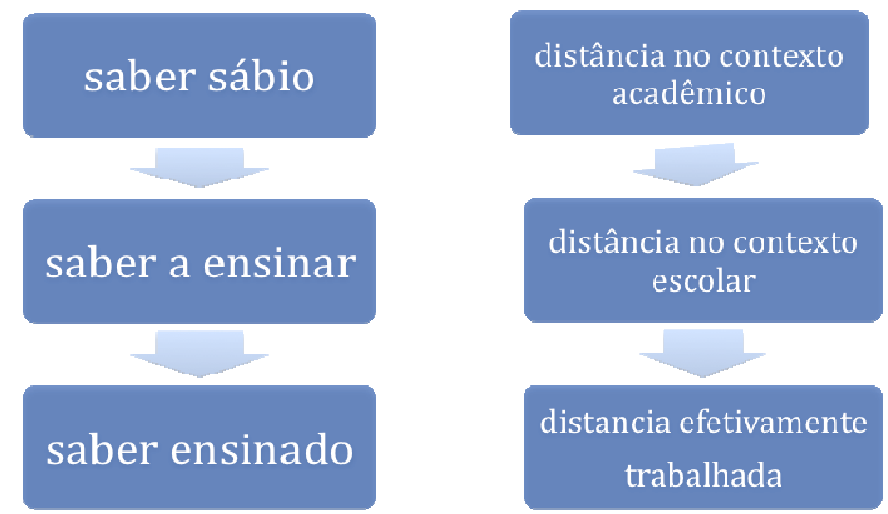

Figura 1: Os tipos de saberes e o conceito de distância

A bem conhecida análise sobre o "contexto da descoberta" e o "contexto da justificação", apresentada pelo filósofo da ciência alemão Hans Reichenbach (1891-1953), mostra o processo de transformação semelhante ocorrido durante a criação de um saber até a forma final como apresentado à comunidade científica (Alves FILHO, 2000, p. 223). Durante sua elaboração, o "contexto da descoberta", um saber passa por transformações e sofre influência de inúmeros fatores, até ser sistematizado racionalmente em linguagem adequada para ser apresentado à comunidade acadêmica. Nesse segundo momento, o "contexto da justificação", todo o caminho percorrido no seu desenvolvimento é "reescrito" e reconstruído racionalmente seguindo os padrões estabelecidos pela comunidade científica. Todos os aspectos considerados irrelevantes nesse relato final são simplesmente ignorados, embora possam ter sido significativos no processo de elaboração do conhecimento (Pietrocola, 2006, p. 315-333; Alves Filho, 2000, p. 223). Esse saber acadêmico é considerado como o saber original, o conhecimento científico sistematizado, onde se inicia todo processo da Transposição Didática (SIQUEIRA, 2006, p. 69).

É interessante observar, que o Saber Sábio sofre transformações desde o âmbito de sua produção/sistematização/divulgação, visando sobretudo sua formulação discursiva e adequação aos condicionantes do sistema didático. Tais transformações objetivam adaptar a forma de apresentar conhecimento aos requisitos de cada uma dessas etapas. Para Chevallard (1991, p. 24) algumas exigências transformam o saber, entre elas a 
despersonalização, que é o requisito para a publicidade do saber, ao ser compartilhado na comunidade acadêmica.

Outros tipos de saberes, produzidos fora da comunidade acadêmica, parecem não ter sido incluídos por Chevallard (1991) no contexto do desenvolvimento da transposição didática, tanto no trabalho de 1982 em conjunto com Joshua, como na primeira edição da sua obra em 1985. Segundo Gabriel (2001, p. 7), não há, nessa perspectiva, “nenhum ou muito pouco espaço para se pensar outros saberes passíveis de se articularem nas diferentes práticas educativas”. Ricardo (2005, p. 166) também aponta essa limitação, apresentando a crítica que Michel Caillot faz à transposição didática e discutindo algumas situações em que outros saberes, além do acadêmico, são selecionados para programas de ensino. Há, por exemplo, algumas disciplinas legitimando os saberes técnicos, artesanais e práticos como necessários à formação do aluno. Tais conhecimentos foram chamados por Martinand de práticas sociais de referência. Segundo Siqueira (2006, p. 76), tais práticas permitem uma relação dos conteúdos com a cultura e com o cotidiano dos alunos. Dentre elas estariam: práticas de técnicas do engenheiro ou do técnico, práticas domésticas (cozinha por exemplo), práticas sociais etc. Estas práticas dependem dos contexto cultural de uma sociedade, de como valores econômicos e políticos influenciam as escolhas didáticas. Caillot aponta, também, deliberações oficiais para os programas disciplinares incluindo competências exigíveis, além dos respectivos conteúdos, enfatizando o adjetivo "exigíveis" atribuído à palavra competências significando ser avaliável pela instituição.

Parece-nos nesse caso não haver uma rejeição, por parte de Chevallard, de outros saberes que não o acadêmico como válidos para serem incluídos no saber escolar. $\mathrm{O}$ fato de ter selecionado um conteúdo específico para sua análise não implica em excluir outros saberes. Isso não significa, a nosso ver, uma prescrição, nem uma restrição curricular, mas a opção por analisar conceitos específicos provenientes do saber acadêmico até o ambiente escolar.

O Saber a Ensinar constitui-se no patamar dos saberes já transformados, prontos para serem inseridos no sistema didático. Ele se materializa na produção de livros didáticos, manuais de ensino e de conteúdos curriculares. O processo de transformar o Saber Sábio em Saber a Ensinar corresponde à Transposição Didática Externa (CHeVAlLaRD, 1991).

Uma primeira interpretação prévia dessa noção poderia sugerir: 
[...] uma mera simplificação ou trivialização formal dos objetos complexos que compõem o repertório do saber sábio. Esta interpretação é equivocada e geradora de interpretações ambíguas nas relações escolares, pois revela o desconhecimento de um processo complexo de transformação do saber. (ALVES FILHO, 2000, p. 225).

O Saber Sábio possui regras bem específicas ditadas pela comunidade acadêmica, tanto com relação à sua produção quanto à sua sistematização e comunicação, que o tornam inadequado ao sistema de ensino básico. Desse modo, é necessário ocorrer uma transformação desse conteúdo para adequá-lo ao ambiente escolar. "Assim como o Saber Sábio é submetido a regras e linguagem específicas, o Saber a Ensinar também tem suas regras próprias" (ALVES FILHO, 2000, p. 225).

Chevallard (1985) realizou uma análise epistemológica sobre as mudanças sofridas pelo Saber Sábio para tornar-se um Saber a Ensinar. Tais reflexões são voltadas à natureza e às condições impostas por requisitos sociais e pedagógicos ao elemento "saber escolar". Essa análise, desenvolvida a partir as idéias de Verret, apontou não ocorrer apenas uma simplificação, mas que os saberes sábio e escolar possuem um estatuto epistemológico distinto. Para um determinado conteúdo ser passível de ser ensinado precisa sofrer modificações, atendendo às condições impostas pela prática pedagógica, tornando-se apto a ser ensinado (CHEVALlaRd, 1991, p. 16).

É importante compreender a análise de Chevallard dentro desse quadro teórico articulando a reflexão epistemológica à reflexão pedagógica. Seus estudos mostraram que a noção de distância como Saber Ensinado nas escolas francesas passou por grandes transformações desde sua proposta no ambiente acadêmico das matemáticas, tornando-se acessível a não especialistas. (CHEVALLARD; JOSHUA, 1982).

Desse modo, o conceito de transposição didática implica no reconhecimento da diferenciação entre saberes específicos de natureza e funções sociais distintas, nem sempre evidente nas análises sobre a dimensão cognitiva do processo de ensino aprendizagem (GABRIEL, 2001). Para ocorrer essa transformação, o Saber Sábio sofre uma descontextualização, ou seja, ele é retirado do campo de problemas onde emergiu historicamente (CHeVallard; Joshua, 1982, p. 169).

O saber que a transposição didática produz será, portanto, um saber exilado de suas origens e separado de sua produção histórica na 
esfera do saber Sábio, legitimando-se, tanto em saber ensinado, como algo que não é de nenhum tempo e nenhum lugar, e não legitimando-se à partir de um produtor, qualquer que seja ele. (CHEVALLARD, 1991, p. 18).

A construção de um saber adequado ao ambiente escolar é fruto de processos de didatização: a dessincretização do saber, a despersonalização do saber, a programabilidade da aquisição do saber, a publicidade do saber e o controle social das aprendizagens (CHEVALLARD, 1991, p. 69). Esses processos são coerentes com os interesses sociais, políticos e econômicos do projeto formativo em que se insere um sistema de ensino, manifestados no seu projeto educacional (ALVES FILHO, 2000, p. 225; RICARDO, 2005, p. 161).

O primeiro passo para a elaboração do Saber a Ensinar é o reconhecimento do processo necessário de dessincretização, uma separação entre as práticas referentes à criação teórica de um saber no âmbito acadêmico e as especializações pertinentes às práticas da aprendizagem. Isso decorre, primeiramente, da necessidade de uma explicitação discursiva, de uma textualização, conduzindo a uma independência dos saberes, cada qual com seu discurso autônomo. A consciência dessa delimitação de saberes parciais independentes está presente nos agentes da transposição didática, por exemplo, justificando as escolhas dos autores de materiais didáticos (CHEVALLARD, 1991, p. 69-70).

O Saber Sábio, resulta de saberes produzidos durante muitos anos, é dividido em partes, separado do contexto e do problema originais, para então ser reorganizado, reconstruído. Em tal processo de dessincretização o saber é desvinculado do ambiente epistemológico original para ser reconstituído em um novo contexto epistemológico.

Outro processo da elaboração do Saber a Ensinar é a despersonalização. Enquanto na comunidade acadêmica a despersonalização do saber visa sua difusão e a produção social do conhecimento, no funcionamento didático ela objetiva a reprodução e representação do saber, sem as exigências do contexto de sua produção (CHEVALLARD, 1991, p. 24-25). Desse modo, para a construção do Saber a Ensinar,

Assiste-se a um fenômeno de deshistorização pelo qual o saber adquire o aspecto de uma realidade ahistórica, atemporal que se impõe por ela mesma e que, não tendo produtor, aparece livre em relação a todo processo de produção, não se podendo contestar sua origem, utilidade e pertinência. Saber anônimo, saber descontextualizado de sua 
produção histórica, que toma o aspecto irrefutável de um conjunto de verdades naturais. Ali se encontra precisamente um dos mecanismos constitutivos do apego exagerado à regras própria do ensino que define um certo modo de relação ao saber, o qual se impõe como evidente, não por emanar de uma autoridade superior, de um mestre, cuja palavra é a verdade, mas ao contrario, porque é totalmente desvinculado de qualquer pessoa. A despersonalização do saber, própria da transposição didática, é tão evidente para nós que não a abandonamos mais (CHEVALLARD; JOSHUA, 1982, p. 169-170).

O processo da despersonalização é uma conseqüência necessária do processo de preparação didática, para retirar os conhecimentos produzidos no âmbito acadêmico, no nicho interno da pesquisa, para poder ser compreendido no ambiente escolar básico (RICARDO 2005, p. 161). Passa-se assim, para a terceira etapa do processo de preparação didática, a textualização do Saber a Ensinar: a publicidade.

Para um determinado saber ser compreendido e apropriado pelos professores e alunos, ou seja, os que deverão transmiti-lo e recebê-lo, ele necessita possuir um certo grau de publicidade (RICARDO, 2005, p. 161). Na construção dos manuais didáticos e demais recursos que chegarão à sala de aula (o processo de textualização) busca-se uma explicitação discursiva objetiva, imprescindível para tornar os saberes ensináveis. A objetividade encontrada nesses textos do saber é a evidência da publicidade que ali se representa (CHEVALLARD, 1991, p.73).

Depois de passar pelos processos da desincretização, despersonalização e publicidade, o texto do Saber a Ensinar que foi elaborado demonstra uma programabilidade da aquisição do saber, expressão designada por Verret (CHEVALLARD, 1991, p. 73).

O texto é uma norma de progressão no conhecimento. Um texto tem um princípio e um fim (provisório) e opera por um encadeamento de razões. (CHEVALLARD, 1991, p. 73).

A organização do Saber a Ensinar encerra em si mesmo uma proposta de aprendizagem. Um determinado material didático, ou programa disciplinar, traz um seqüenciamento de conteúdos que busca viabilizar e favorecer a relação do sujeito com o 
conhecimento. Tal organização evidencia a programabilidade da aquisição dos saberes, identificados e designados mediante um projeto social de ensino e aprendizagem.

Desses quatro processos da transposição didática, descritos acima, resulta um texto que pode ser considerado como um "instrumento de avaliação específico," no sentido de exercer o controle social da aprendizagem. Ali se encontram os conteúdos selecionados para o Saber a Ensinar, dessincretizados, despersonalizados, publicizados em uma textualização que denota a programabilidade do saber:

Esta publicidade, por sua vez, possibilita o controle social da aprendizagem, em virtude de uma certa concepção do que significa saber, concepção fundada (ou legitimada, ao menos) pela textualização. [...] Ao se conceber a aprendizagem como equivalente ao progresso manifestado na própria estrutura do texto, este permite medir àquele e torna possível uma didática essencialmente "isomorfa"[...]. (CHEVALLARD, 1991, p. 73, grifo nosso).

O texto do Saber a Ensinar é, portanto, autorizado didaticamente, legitimado por "uma concepção de aprendizagem, cujo modelo ordenador é o texto do saber em sua dinâmica temporal" (CHEVALLARD, 1991, p. 73). Esse processo de elaboração dos saberes a ensinar levam em conta, segundo Ricardo (2005, p. 162), as etapas da aprendizagem e o tempo escolar disponível para isso. Chevallard (1991, p. 75) designou essa relação saber/duração como tempo didático. Sempre tendo em mente que a produção de um sistema didático leva em conta o projeto social de ensino, Chevallard propõe os quatro processos da transposição didática produzindo um texto de saber que possibilita uma relação específica com o tempo didático.

Assim, os saberes que integram o texto do Saber a Ensinar não são apresentados do mesmo modo que surgiram no Saber Sábio, nem no "contexto da descoberta", tampouco no "contexto da justificação". Há uma diferença marcante entre o tempo de produção do conhecimento e o tempo didático. A programabilidade dada a esse saber omite os processos envolvidos na sua elaboração, mas explicita o tempo didático. Até que ponto isso pode representar um problema? Essa questão será retomada e aprofundada mais adiante. $^{7}$

\footnotetext{
${ }^{7}$ Quando da aplicação desta teoria ao nosso objeto de pesquisa.
} 
De qualquer modo, deve-se compreender que, ao se submeter ao processo de didatização, o Saber Sábio é transformado, resultando em um novo saber. Esse saber possui função social distinta daquele. Esse novo saber possui epistemologia própria. Reconhecer essa separação é fundamental. Porém, daí decorre uma importante questão: como conferir legitimidade a esse novo saber? Como e por quem será legitimado?

Admitir a separação entre Saber Sábio e Saber Escolar impõe aceitar que a legitimidade do primeiro não pode legitimar o segundo do ponto de vista epistemológico. Ricardo (2005, p. 160) coloca que a credibilidade assegurada pela legitimidade epistemológica atribuída à física pela comunidade científica em uma perspectiva kuhniana, por exemplo, não é garantia para a física ensinada na escola básica.

A legitimidade do Saber a Ensinar deve vir do entorno sociocultural em que um determinado sistema de ensino está inserido (RICARDO, 2005, p. 161). Segundo Ricardo (2005, p. 163), “os saberes presentes na escola são colocados à prova e envolvem um conjunto de atores bem mais complexo que a comunidade cientifica, pois o jogo de interesses é maior”. Desse modo, tornam-se pertinentes as questões: Quem são esses atores? Que papel representam nesse entorno sociocultural?

$\mathrm{Na}$ arte de ensinar, o novo saber entra em conflito léxico com o ambiente escolar, e esse conflito nos ajuda a entender a trajetória do saber sábio, do qual conhecemos a origem, e poderemos identificar o lugar de chegada no sistema de ensino. Entre a saída e a chegada verifica-se uma mudança de natureza do elemento (CHEVALLARD; JOSHUA, 1982, p. 167).

Na origem do processo de transposição está a seleção dos saberes que serão levados ao ambiente escolar, e os fatores que concorrerão para essa eleição estão imersos no ambiente sociocultural. Como se dá o processo de seleção? Quais os critérios para o processo de escolha e quem são os personagens que participam dessa eleição e da transformação do Saber Sábio em Saber a Ensinar?

No primeiro capítulo de seu livro, Chevallard (1991) apresenta a transposição didática e, deixando explícita sua perspectiva sociológica do processo, adota como pressuposto: 
Todo projeto social de ensino e aprendizagem se constitui dialeticamente com a identificação e a designação de conteúdos de saberes como conteúdos a ensinar (CHEVALLARD, 1991, p. 45).

Portanto, a seleção dos conteúdos do Saber Sábio a serem transformados em Saber a Ensinar é orientada pelo projeto social de ensino e aprendizagem, no contexto sociocultural no qual o sistema educacional está inserido. Por meio de uma complexa rede de negociações entre diversos personagens, os conteúdos de saber serão selecionados, e pelo mesmo ambiente sociocultural serão também aceitos e legitimados.

Chevallard (1991, p. 28) propõe o nome noosfera para o espaço de interação entre o sistema de ensino stricto sensu e o seu entorno social.

Ali se encontram todos aqueles que ocupam os postos principais do funcionamento didático, se enfrentam com os problemas que surgem de encontro com a sociedade e suas exigências; ali se desenvolvem os conflitos, ali se levam a cabo as negociações; ali se maturam soluções. [...] estamos aqui na esfera onde se pensa - segundo modalidades muito diferentes - o funcionamento didático. Para esta instância sugeri o nome paródico de noosfera. (CHEVALLARD, 1991, p. 28, grifo nosso).

$\mathrm{Na}$ noosfera estão todas as pessoas e/ou instituições que influenciam o sistema educacional e as transformações sofridas pelo saber. Nesse espaço ocorrem as negociações que tentam delimitar as competências, as responsabilidades e as ações dos indivíduos envolvidos nesse processo: os autores de livros didáticos, os formuladores de políticas ligadas à educação, pesquisadores em educação, professores, representantes da sociedade, como os pais de alunos, especialistas das disciplinas e outros interessados no processo de ensino (CHEVAllard, 1991, p. 27-28). Os cientistas também influenciam, de maneira indireta mas significativa, a seleção e a transformação do saber. Na noosfera se definem os currículos face às necessidades e aos anseios da sociedade selecionando-se o conteúdo do Saber Sábio e realizando-se as transformações, sempre guiadas pelo projeto educacional (Alves FilHo, 2000, p. 231-232; SiQUeIRA, 2006, p. 67-68).

A construção dos saberes escolares deve reconhecer a diversidade de formas de racionalidade e validade de conhecimentos, pressupondo uma epistemologia plural, articuladora da razão pedagógica à sociológica, antropológica, política etc., e conferindo, 
dessa forma, legitimidade cultural ao Saber a Ensinar (GABRIEL, 2001). Desse modo, a transposição didática representa o complexo processo de transformações adaptativas que produzem o objeto de ensino, legitimado tanto epistemologicamente, quanto culturalmente (Chevallard, 1991, p. 45; RiCARdo, 2005, p. 160-161).

Note-se que a noosfera, o sistema de ensino e a sala de aula não são instâncias autônomas. Imersas em um mesmo contexto social, elas se relacionam e se influenciam mutuamente. Nessa visão sociológica, o projeto político-pedagógico guia o processo da transposição, levando em conta uma epistemologia plural e as razões pedagógicas do ambiente escolar. Desse modo, a noosfera, compreendida em seu contexto, define e transforma, mas também legitima o Saber a Ensinar.

Os manuais e livros didáticos, assim como os documentos oficiais (por exemplo os PCNs no caso brasileiro) e os currículos e programas adotados pelo sistema de ensino são os produtos mais facilmente identificados com o Saber a Ensinar. Chega-se assim ao objeto da didática definido por Chevallard: o sistema didático, no qual ocorre a relação didática entre o saber, o professor e o aluno.

No interior do sistema didático, o Saber a Ensinar passará ainda por outra transposição, menos visível do que o trabalho realizado na noosfera, guiada pelo processo do ensino-aprendizagem (ANHORN, 2004).

Para tornar possível o ensino de um determinado elemento do saber, ele deve ter sofrido certas deformações. O Saber-tal-como-éensinado, o saber ensinado, é necessariamente distinto do saberinicialmente-designado-como-o-que-deve-ser-ensinado, o saber a ensinar (CHEVALLARD, 1991, p. 16-17).

Isso significa que a transposição didática ocorre em dois níveis distintos:

a) Transposição didática externa: ocorrida na noosfera que transforma o Saber Sábio em Saber a Ensinar;

Neste nível, os agentes da noosfera, inseridos no contexto sociocultural de cada ambiente educacional, definem os saberes que devem ser ensinados antes mesmo que estes cheguem efetivamente ao ambiente escolar.

b) Transposição didática interna: ocorrida no interior do sistema didático que transforma o Saber a Ensinar em Saber Ensinado. 
Neste nível, as ações do professor guiam a transformação que o Saber a Ensinar sofre até tornar-se o Saber Ensinado. Vale destacar que:

O saber ensinado supõe um processo de naturalização, que lhe confere a evidencia incontestável das coisas naturais; sobre essa natureza "dada", a escola espera agora sua jurisdição, fundadora de valores que, daqui para frente, administram a ordem didática (CHEVALLARD, 1991, p. 18).

O professor trabalha na transposição didática interna mediando a interação entre ele, o aluno e o saber (CHEVAlLARD, 1991, p. 20). Entretanto, ele não é um sistema fechado, pois as relações não são meramente objetivas. Lida-se com o entorno no qual esse microuniverso está imerso: seus valores, as expectativas de seu ambiente sociocultural e a história de vida dos sujeitos, o aluno e o professor.

A complexa e dinâmica relação entre as variáveis do sistema didático configura-se ímpar, singular e, em alguns momentos, imprevisível. Espera-se, é claro, que o professor esteja preparado para lidar com a singularidade das relações didáticas e demais anseios da esfera que envolve esse sistema, e que irão interferir nas escolhas didáticas ( $c f$ RICARDO, 2005, p. 160-162).

Chevallard define esses sistemas didáticos como formações que aparecem a cada ano, por ocasião do início do ano letivo, ao redor de um saber designado pelo programa disciplinar. O Saber a Ensinar torna-se objeto de um projeto de ensino e aprendizagem, que agrupa em um mesmo lugar professores e alunos, cujas relações são mediadas por um contrato didático. ${ }^{8} \mathrm{O}$ sistema de ensino contempla um conjunto de sistemas didáticos e utiliza dispositivos estruturais para tornar seu funcionamento viável. No entorno do sistema de ensino está a sociedade laica, em contraste com a sociedade de especialistas que o compõem. Todo o entorno do sistema de ensino e do sistema didático irá influenciar as escolhas do professor ao atuar na didática interna. (CHEVALLARD, 1991, p. 26-27).

Outro fator que influencia o processo da transposição interna é o tempo de aprendizagem do aluno, uma das quatro concepções temporais da transposição didática (tempo real, tempo lógico, tempo didático e tempo de aprendizagem) (CHEVALLARD, 1991,

\footnotetext{
${ }^{8}$ Chevallard refere-se aqui ao contrato didático proposto por Brousseau.
} 
p. 75-80). Segundo Pietrocola (2008), o gerenciamento do tempo disponível para o ensino é um dos fatores que justifica a seleção e adaptação do saber. No caso da física, por exemplo, deve-se fazer caber quatro séculos de conhecimentos em três anos, com duas a três aulas semanais.

No caso da Física, tempo real está relacionado ao tempo histórico, no qual determinado saber se desenvolveu. [...] O tempo lógico relaciona-se à maneira de encadear a apresentação desse conhecimento para fins de ensino. Ao se organizar uma seqüência didática de atividades de ensino-aprendizagem, define-se um tempo específico para tratar esse conceito. Já o tempo didático vincula-se àquilo que poderá ser feito na sala de aula. [...] Finalmente o tempo de aprendizagem variará muito de aluno para aluno. Alguns aprendem durante a própria aula, nesse caso tempo didático e tempo de aprendizagem serão iguais. (PIETROCOLA, 2008)

O professor ao preparar sua aula deve considerar o tempo de interação necessário entre o aluno e o Saber a Ensinar, que varia de aluno para aluno, sendo em geral diferente do tempo didático. A complexidade temporal estabelecida no sistema didático requer a constante atuação do professor na transposição didática interna.

Segundo Anhorn (2004), todo o processo da transposição didática encontra seus maiores desafios no interior do sistema de ensino, cuja dinâmica de funcionamento busca assegurar a viabilidade do aprendizado de um determinado saber. Tais desafios devem ser vistos no âmbito disciplinar, isto é:

[...] deve ser compreendido na dinâmica específica dos saberes escolares, no decorrer do processo de ensino e aprendizagem. Dessa forma, o conhecimento do funcionamento didático de uma disciplina torna-se indispensável para a compreensão do processo de transposição na sua globalidade. (ANHORN, 2004)

Desse modo, quando o professor prepara sua variante local do texto do saber, ele não realiza uma seleção teórica, mas se depara com questões técnicas de extensão e segmentação do saber. O professor atua na transposição didática interna, imerso no entorno do sistema didático, e sendo por ele constantemente influenciado (CHEVALLARD, 1991, p. 20-21). 


\subsubsection{A sobrevivência de um saber}

Analisar todo percurso de um saber, que passa pela transposição didática externa do Saber Sábio ao Saber a Ensinar, e posteriormente sofre a transposição didática interna que produz o Saber Ensinado, permite-nos compreender três instâncias dessa problemática (CHevallard, 1991, p.16):

- A separação obrigatória entre o saber acadêmico e o escolar;

- O questionamento necessário sobre a origem e legitimidade cultural do Saber a Ensinar;

- A contribuição da transposição didática como ferramenta de análise, por meio do exercício da vigilância epistemológica nos saberes transpostos.

Tal ferramenta permite uma fundamentação teórica para uma prática pedagógica mais reflexiva, auxiliando o professor em sua ação educativa. Além disso, observar os saberes escolares, sob a lente da transposição didática, torna possível inferir algumas características que concorrem para tornar um saber "ensinável” (BROCKINGTON, 2005; Pietrocola, 2008; SiqueIRA, 2006). Tais características buscam favorecer o processo de ensino-aprendizagem, além de atender a interesses sociopolíticos da noosfera. As características são discutidas por Chevallard (1991) em diversos pontos da obra e podem ser assim resumidas:

- Um conteúdo do Saber a Ensinar tem que ser consensual, possuindo um status de verdade contemporânea ou histórica. Todos os setores da sociedade relacionados ao sistema de ensino não podem ter dúvidas sobre seu valor.

- Um Saber a Ensinar deve ter atualidade moral: ser considerado importante e relevante pela sociedade em geral para integrar o currículo escolar.

- Um Saber a Ensinar não pode distanciar-se demasiadamente do saber acadêmico que lhe serviu de referência, demonstrando atualidade biológica, caso contrário torna-se defasado de sua ciência de referência e tem sua legitimidade questionada pelo entorno social.

- Operacionalidade significa que um Saber a Ensinar deve possibilitar a elaboração de atividades didáticas, exercícios e instrumentos de avaliação, pois os saberes que não permitem ter seu aprendizado avaliado fatalmente não permanecerão na escola. 
- Um Saber a Ensinar deve favorecer a criatividade didática, na elaboração de atividades voltadas ao contexto escolar, ou seja, objetos de ensino que não possuem similares no Saber Sábio.

- Finalmente, o Saber a Ensinar será considerado viável quando apresentar terapêutica, isto é, tiver sido validado com os resultados obtidos pela aplicação em sala de aula, que fornecerá os limites e as possibilidades didáticopedagógicas.

É importante não se considerar essas características como regras prescritivas. Os requisitos descritos acima devem ser considerados como atributos inferidos da análise dos saberes escolares presentes no sistema didático. Dessa forma, eles materializam características dos saberes escolares que tendem a assegurar sua adequação ao sistema escolar, mas não garantir. Devem ser tomados como guias de análise, mais ou menos gerais.

Pietrocola (2008) enfatiza que os saberes presentes nos currículos e programas escolares são o resultado de um processo de validação coletiva de muitos anos. Aqueles conteúdos que permanecem estabilizados por longo tempo são os que atenderam em grande parte aos requisitos descritos acima, ou seja, incorporam essas seis características.

De tempos em tempos, vemos novos conteúdos sendo inseridos nos programas escolares. Nas últimas décadas, por exemplo, é possível citar a física moderna e contemporânea, mudanças no cenário político nacional e internacional, novos conhecimentos sobre biologia molecular e atualizações gramaticais e lingüísticas.

\subsection{Desafios na transposição didática da história da ciência}

Os conteúdos curriculares considerados como tradicionais no ensino de ciências, vêm sobrevivendo por algumas décadas nos planejamentos escolares, são explicitados nos livros didáticos e praticamente consolidados pelas avaliações em pequena e grande escala, como os vestibulares, o Enem, o Saresp etc. No caso da história da ciência, entretanto, raramente se encontram conteúdos explícitos nessas instâncias. Enquanto tópicos como as "Leis de Newton", "Propagação do calor", "Reflexão da Luz" e "Corrente Elétrica”, por exemplo, surgem descritos de modos similares na ampla maioria dos livros didáticos, normalmente não encontramos conteúdos históricos como "O papel das hipóteses na doutrina newtoniana", "A problemática do uso de instrumentos para a observação da 
natureza nos debates entre Galileu e a Igreja" ou "O papel do éter luminífero nas equações de Maxwell”. Isso não significa, contudo, que tais conteúdos deveriam estar lá, ou ainda, que tais conteúdos não estejam lá.

Pesquisas educacionais nesse âmbito têm constatado supostos conteúdos históricos "decorando" materiais escolares com imagens dos grandes personagens e narrativas distorcidas da história da ciência, que fomentam uma visão equivocada da natureza da ciência, como se estas fossem inócuas. Nos livros didáticos, predominam pequenos trechos de narrativas anacrônicas excessivamente simplificadas, carregadas de juízos de valor, transmitindo a visão linear, whig, algumas vezes até mesmo hagiográfica dos grandes pensadores e do modo como teriam construído a história da ciência (ALLCHIN, 2004; 2006; EL Hani, 2006; Gil Perez et al., 2001; Holton, 2003; Martins, A., 2007; Medeiros; BEZERRA, 2000; MCCOMAS et al., 1998; PUMFREY, 1991; PAGLIARINI, 2007).

$\mathrm{Na}$ ampla maioria dos casos, essas são as únicas versões conhecidas pelo professor, um dos tripés da relação didática, tornando difícil, ou mesmo impossível, que ele detecte problemas e saiba lidar com tais abordagens de maneira crítica. Conforme apontam Gil Perez e colaboradores (2001), predomina no ambiente escolar uma visão positivista da ciência, que reforça e é reforçada pelas narrativas históricas que transmitem o mesmo ponto de vista. Segundo Almeida (2006, p. 27), essa concepção positivista de ciência dominou o cenário educacional ao longo de todo o século $\mathrm{XX}$, tanto na formação de professores como no ensino de um modo geral, pois a base epistemológica que sustenta tal concepção confere legitimidade a uma racionalidade técnica ou razão instrumental, direcionada para soluções de problemas científicos e técnicos. Todo esse quadro teórico difere fundamentalmente dos objetivos praticamente consensuais nas pesquisas em ensino de ciências que prescrevem a relevância de ensinar uma visão contemporânea sobre a natureza da ciência (LEDERMAN, 2007).

Isso significa que a transposição da história e filosofia da ciência para o ambiente escolar requer lidar com diversos desafios, por exemplo: a seleção dos conteúdos do Saber Sábio a serem transformados em Saber a Ensinar que atendam aos objetivos pedagógicos elencados; harmonizar a necessidade de descontextualização, dessincretização, despersonalização dos saberes acadêmicos com os cuidados para evitar a construção da pseudo-história; conciliar o nível de abstração requerido para se lidar com a complexidade 
da dimensão histórico-epistemológica e respeitar a necessidade da publicidade do Saber a Ensinar.

Há também a questão do tempo didático levado em conta nos quatro processos da transposição didática para a produção de um texto de saber; por exemplo, tratar os saberes da física produzidos ao longo de três séculos em três anos da escola básica (PIETROCOLA, no prelo). Todavia, quando se pensa na abordagem história, é necessário considerar ainda outros requisitos. As próprias características do saber histórico e a necessidade intrínseca de tratar o passado em seus próprios termos são mais um desafio na construção do Saber a Ensinar. Monteiro aponta alguns problemas decorrentes de uma abordagem anacrônica da História:

Como já foi comentado, é muito freqüente o uso, pelos professores, de atividades onde são desenvolvidas analogias com situações similares à estudada, e encontradas na "realidade do aluno", em situações do tempo presente. Muitas vezes estas analogias induzem a erros, pois operam numa dimensão comparativa muito simplificada, conduzindo os alunos a atribuir à situação do passado o mesmo significado encontrado na situação do presente. Além disso, tendem a levar o aluno a ignorar as diferenças no tempo, suprimindo um aspecto fundamental no ensino da história que é fazer perceber e compreender as diferenças entre temporalidades. $O$ anacronismo representa uma ameaça, portanto, seja do ponto de vista do significado daquilo que é objeto de estudo, seja do ponto de vista da própria construção do raciocínio histórico. (MONTEIRO, 2005).

A transposição do Saber Sábio histórico em Saber a Ensinar é um aspecto delicado quando se pensa na dessincretização. Porém, tal especificidade não significa que o conteúdo histórico seja distorcido no percurso epistemológico da criação do seu “equivalente" Saber a Ensinar. É importante não perder de vista que a dessincretização afastará os sujeitos e sua ação no processo de construção e de publicização do Saber Sábio. Tais saberes serão apartados do seu contexto de criação, dos historiadores e dos processos envolvidos em sua elaboração, e do tempo requerido nesse preparo. Esse objeto de Saber a Ensinar, que nasce atemporal e desvinculado do seu contexto de criação não será, necessariamente, desvinculado dos fatos históricos que pretende narrar. Esse Saber a Ensinar histórico que ganha vida no ensino de ciências pode preservar os condicionantes 
contextuais, tanto quanto foi possível enquanto Saber Sábio. Desse modo, ao se pensar no tempo didático da transposição de conteúdos históricos ao ensino de ciências, é necessário entender a dimensão temporal na perspectiva diacrônica da localização temporal dos fatos históricos transpostos.

Vários dos desafios que se enfrenta ao levar conteúdos históricos para a educação científica são os mesmos encontrados em outros conteúdos curriculares. Eles podem ser entendidos em termos de dificuldades conjunturais enfrentadas por todas as disciplinas. Muitos são bem conhecidos e amplamente tratados na literatura educacional; por exemplo, as salas de aulas com grande número de alunos, os baixos salários dos professores e o grande número de aulas que precisam assumir para melhorar sua renda, o que acaba dificultando os estudos e os investimentos em sua formação continuada. A carência de bibliotecas, de laboratórios, de material pedagógico adequado para um ensino que possa motivar o aluno são também dificuldades conjunturais que o professor não pode superar sozinho, e extrapolam os muros disciplinares. Embora tais dificuldades sejam de fato enfrentadas pelos diversos campos disciplinares, elas não são objeto de estudo de nossa pesquisa.

Por outro lado, há alguns desafios que são intrínsecos de campo disciplinar, e o uso da história e filosofia da ciência no ensino apresenta suas próprias dificuldades, além daquelas conjunturais. Há alguns obstáculos didático-pedagógicos próprios da utilização da história e filosofia da ciência na escola básica. Acreditamos que tais obstáculos podem ser superados ou compensados por meio da pesquisa educacional. Esses últimos serão nosso próximo objeto de análise, denominados obstáculos estruturais.

\subsubsection{Obstáculos estruturais da abordagem histórico-epistemológica na educação científica}

Quando se busca utilizar a história da ciência em ambiente escolar, é necessário, antes de tudo, ter claro o objetivo pedagógico que se pretende atingir. Nossa pesquisa volta-se ao uso da história para ensinar sobre o fazer científico, o que implica em uma abordagem empírica da natureza da ciência, conforme discutimos no capítulo 1 (MARTINS, 1993). O segundo passo, nesse caso, volta-se à seleção apresentada na seção 1.2.4 dos aspectos consensuais apresentados como pertinentes e necessários para o ensino de ciências (MCCOMAS et al., 1998; El HANI, 2006; GIL PEREZ et al., 2001; PUMFREY, 1991), e são listados novamente abaixo: 
- a natureza não fornece dados suficientemente simples que permitam interpretações sem ambigüidades;

- uma observação significativa não é possível sem uma expectativa preexistente;

- a ciência é uma atividade humana influenciada pelo contexto sociocultural de cada época;

- teorias científicas não podem ser provadas e não são elaboradas unicamente a partir da experiência;

- o conhecimento científico baseia-se fortemente, mas não inteiramente, na observação, evidência experimental, argumentos racionais e ceticismo.

Dessa forma temos definidos o propósito pedagógico e os aspectos epistemológicos a abordar. O próximo desafio a enfrentar na construção do Saber a Ensinar é a seleção do conteúdo histórico. É necessário avaliar quais tópicos extraídos da história da ciência possuem as características que permitam abordar, em sala de aula, as discussões em torno desses objetivos. Conforme discutimos no capítulo 1, há muitos aspectos da natureza da ciência que podem se prestar a propósitos pedagógicos, e há diversos conteúdos da história da ciência que podem exemplificá-los. Nesse sentido, é importante considerar parâmetros que permitam julgar o sucesso dos conteúdos em se adequar aos condicionantes do sistema de ensino, ao mesmo tempo em que satisfazem os propósitos pedagógicos de formação pretendidos, e também aqueles epistemológicos.

Um ponto a ser ponderado diz respeito ao tempo didático, ou seja, o tempo disponível para abordar o conteúdo histórico selecionado em sala de aula. Viabilizar o conteúdo histórico no tempo didático disponível em cada contexto caracteriza-se como um obstáculo específico, tanto do ponto de vista pedagógico quanto historiográfico. O tempo didático disponível varia de acordo com o ambiente educacional escolhido e em geral implicará em limitar a quantidade de conteúdo histórico possível de se abordar. Por outro lado, uma excessiva simplificação pode acarretar um grande risco em termos de distorção histórica (veja seção 1.2.3.). É necessário selecionar episódios históricos bem delimitados sem incorrer em narrativas históricas muito superficiais.

Outro ponto importante surge na determinação do nível de profundidade a ser dado aos conteúdos históricos selecionados. Quais aspectos são adequados ao ensino médio? Quais devem ser simplificados? Que detalhes devem ser omitidos sem comprometer a qualidade da narrativa histórica? Tais preocupações se justificam pelos riscos de se 
construir uma pseudo-história. Relatos excessivamente superficiais não poderão contribuir para a compreensão do funcionamento da ciência. Lidar com o fazer científico sem distorcê-lo requer apresentar uma quantidade significativa de detalhes envolvidos na elaboração de teorias, na observação de fenômenos, levando em conta uma contextualização minimamente necessária. Simplificação e omissão é sem dúvida um desafio a enfrentar.

A construção da narrativa histórica apresenta outro desafio. Os aspectos que decidimos enfocar sobre a natureza da ciência buscam problematizar uma visão empíricoindutivista da ciência, normalmente perpetuada no ensino de ciências. De modo geral, quando se afirma os limites da observação na pesquisa científica dos fenômenos naturais corre-se o risco de sugerir ou fomentar a falta de parâmetros objetivos. Deve haver cuidado para não incorrer no relativismo. Desse modo, o conteúdo histórico e a forma de apresentálo deve permitir problematizar a observação neutra dos fenômenos e experimentos, sem entretanto desvalorizar a importância da observação, da evidência experimental, dos argumentos racionais e do ceticismo na construção do conhecimento científico.

Tal problema seria minimizado se os trabalhos de pesquisa publicados pelo historiador da ciência fossem adequados ao ensino de ciências. O resultado do trabalho do especialista, seguindo as prescrições historiográficas atuais, traria um recorte adequado, com um problema de pesquisa bem formulado. Tais trabalhos abordam os aspectos contextuais que têm impacto no objeto de análise, além dos conteúdos científicos e num nível de aprofundamento suficiente para tratar o problema levantado. Desse modo, os trabalhos produzidos pelo historiador da ciência poderiam ser úteis para discutir diferentes aspectos da natureza da ciência, vinculados ao recorte estabelecido em cada trabalho. Essa é uma das razões pelas quais Holton (2003) sugere a aproximação entre os especialistas de ambos os campos. Porém, a textualização, os pré-requisitos conceituais de campos normalmente envolvidos e o aprofundamento dado aos objetos históricos tornam os trabalhos históricos especializados inadequados ao ensino médio.

Outro desafio que se enfrenta nesse processo diz respeito à tradição existente no ensino de ciências com o uso ingênuo da história presente nos livros didáticos. Elas se configuram como pseudo-história com todos os problemas daí decorrentes. Assim, a visãopadrão da história da ciência que tem se perpetuado é justamente uma visão ultrapassada, e sustentada por esses valores ainda implícitos no ensino de ciências (GIL PEREZ et al., 2001; 
LEDERMAN, 2007). Essa problemática é reforçada pela crença que alguns educadores possuem sobre supostos benefícios das reconstruções racionais. Ainda que se apresentem bons argumentos voltados aos imaginados benefícios pedagógicos, acreditamos que os prejuízos trazidos por tais versões não podem ser negados. Não ensinamos pseudo-ciência no ensino de ciências (AllChIN, 2004). Por que deveríamos ensinar a pseudo-história da ciência?

A falta de formação do professor é um dos maiores desafios a se enfrentar. Todos os obstáculos seriam minimizados se o professor tivesse sido preparado para lidar de modo consciente e crítico com todos esses obstáculos (GIL PEREZ et al., 2001). Já colocamos que não julgamos possível, nem necessário, transformar o professor em historiador ou epistemólogo da ciência (ver seção 1.2.3). No entanto, acreditamos ser possível desenvolver ações que busquem fornecer elementos ao professor para lidar com os desafios dos usos da história e filosofia da ciência em ambiente escolar (ALLCHIN, 2004; EL-HANI, 2006; Holton, 2003; MARTins, A., 2007; LEDERMAn, 2007).

Esta primeira reflexão teórica nos permitiu identificar alguns obstáculos estruturais mais gerais. Podemos sintetizá-los da seguinte forma:

- seleção do conteúdo histórico;

- tempo didático disponível;

- simplificação e omissão;

- relativismo;

- inadequação dos trabalhos especializados da história da ciência para o ensino médio;

- narrativas históricas presentes nos livros didáticos;

- supostos "benefícios" das reconstruções racionais;

- formação do professor.

Os desafios que discutimos acima são específicos da transposição didática da história da ciência para a educação científica, diferentes das dificuldades conjunturais que afetam todas as disciplinas e fogem ao nosso alcance. Nós os classificamos como obstáculos estruturais, uma vez que é possível lidar com eles num nível diferente. Enquanto o elevado número de alunos nas salas de aula configura-se como obstáculo conjuntural, comuns a todas as disciplinas, os obstáculos estruturais acima mencionados 
podem ser superados ou ao menos compensados por ações e iniciativas na construção do Saber a Ensinar e o Saber Ensinado.

\subsubsection{Conflitos, dilemas e riscos}

Alguns dos desafios impostos pela necessidade de conciliar distintos campos do conhecimento acabam configurando-se em escolhas difíceis ou mesmo dilemas no sentido de que algumas vezes, qualquer opção escolhida implicará em perdas inevitáveis. Há algumas situações em que se torna muito difícil harmonizar as prescrições historiográficas com requisitos pedagógicos. Entretanto, enfrentar conflitos e dilemas envolve escolhas e riscos.

As considerações teóricas apontam, por exemplo, para a necessidade de se estabelecer um recorte no uso da história da ciência (MARTINS, R., 2001). Em oposição aos relatos anacrônicos muito superficiais, às grandes sínteses e às reconstruções racionais, a metodologia para o estudo dos fatos históricos requer um objeto de pesquisa limitado tematicamente e temporalmente (MARTINS, L., 2005). Por outro lado, pode ser difícil, para o aluno do ensino médio, entender o papel de um determinado evento histórico "isolado" na construção da ciência. Ou ainda percebê-lo como apenas uma, entre várias perspectivas, de fatos que ocorreram no passado, relacionados a uma complexidade de fatores culturais. Seria possível apresentar um relato pontual de um episódio histórico sem que o aluno perca uma visão mais ampla daquele fato na história?

Tal desafio impõe difíceis escolhas: conciliar as prescrições para não se construir uma história da ciência distorcida e, ao mesmo tempo, favorecer uma compreensão contextualizada de conceitos em uma perspectiva histórica mais ampla da construção da ciência. Decidir entre o recorte ou uma abordagem mais ampla, ou seja, a escolha entre extensão versus profundidade pode configurar-se em um conflito. Mais uma vez, a opção por uma dessas abordagens acaba dependendo do contexto de utilização da história e das metas pedagógicas pretendidas no seu uso.

Outro conflito de difícil solução que pode incorrer em dilemas é com relação ao aprofundamento de um episódio histórico selecionado: quais os aspectos a omitir? Nesse caso também será necessário analisar o contexto de cada situação. Os objetivos pedagógicos pretendidos, o nível de escolarização envolvido, os pré-requisitos conceituais necessários ao aluno e ao professor, ou ainda abordagens que sinalizam para aspectos 
especializados da história da ciência. Em que situação um determinado aspecto social, histórico ou científico pode ser considerado "desnecessário" mediante os objetivos pedagógicos almejados? Em que situação um detalhe especializado torna-se crucial para a compreensão de um objetivo pretendido? Esse pode ser o caso da abordagem matemática. Muitos episódios requerem conhecimentos matemáticos num nível de aprofundamento inacessível ao aluno do ensino médio. Por outro lado, tratar um conceito, ou um experimento, ou uma teoria omitindo a matemática seria simplificação ou distorção?

Um conflito que é praticamente um dilema a enfrentar refere-se à textualização da narrativa histórica. Se optamos por construir um texto histórico muito simplificado, de modo a dar publicidade ao Saber a Ensinar para o nível de escolaridade enfocado, corremos o risco de incorrer na pseudo-história. Por outro lado, um relato profundamente comprometido com a busca pela fidedignidade histórica pode tornar-se incompreensível para os alunos. Encontrar o caminho do meio exige persistência, uma dose de criatividade e disponibilidade para ceder, ora de um lado, ora de outro. Temos assim compreensibilidade versus rigor histórico.

Questionar a visão exclusivamente empírico-indutivista da ciência, discutindo os aspectos selecionados da história da ciência implica em riscos potenciais. Criticar uma visão exclusivamente empírica da ciência pode transmitir uma enganosa desvalorização do papel da experimentação na ciência. Além disso, quando se mostra uma ciência historicamente construída, teorias que não podem ser provadas, a existência de diferentes modelos explicativos para um fenômeno natural, e ainda, problemas e limitações nas teorias aceitas por significativos períodos de tempo pode-se sugerir, ou mesmo fomentar, o subjetivismo, que pode implicar numa perspectiva relativista. Temos assim o conflito/dilema objetivismo versus subjetivismo.

Os conflitos e obstáculos previstos pelo quadro teórico estudado apontam alguns desafios e riscos na abordagem histórico-epistemológica no ensino de ciências. Uma reflexão teórica preliminar apontou para alguns conflitos ou dilemas:

- extensão versus profundidade;

• simplificação versus distorção;

- compreensibilidade versus rigor histórico;

- objetivismo versus subjetivismo. 
Uma análise teórica na construção do Saber a Ensinar pode apontar caminhos para lidar com os desafios em termos de obstáculos estruturais, conflitos e dilemas. No entanto, podem-se receber contribuições importantes de uma vivência prática no processo de ensino-aprendizagem dessas dificuldades. Desse modo, realizamos uma análise empírica para complementar a abordagem teórica no enfrentamento de nosso problema de pesquisa, com a implementação de um curso piloto no ensino médio. A parte empírica consistiu na elaboração, acompanhamento da aplicação e análise de uma sequiência de atividades didáticas que utilizam a história da ciência para discutir aspectos epistemológicos da construção do conhecimento científico.

As metodologias envolvidas no desenvolvimento das atividades e no material de um curso piloto, bem como na sua implementação, tomada e análise de dados serão descritas no próximo capítulo. 


\section{Desenvolvimento da pesquisa}

Lá isso, gostamos, sim senhor, mas este é um falar dos dentes para fora, que o coração não entendeu, não chega a ser mentira o falar da boca, mas sim ausência.

Saramago, Memorial do Convento.

As intrincadas e complexas relações que caracterizam os fenômenos educacionais e suas diversas possibilidades de análise metodológica constituem um aspecto fundamental nas pesquisas em Ensino de Ciências. A busca pela coerência e consistência entre marcos teóricos, metodológicos e epistemológicos tem sido objeto de reflexão entre grupos de pesquisa, encontros e publicações internacionais (SANTOS e GRECA, 2006, p. 9-11).

A variedade dos referenciais teóricos utilizados e a conseqüente diversidade metodológica estão relacionadas à natureza das temáticas pesquisadas atualmente em relação ao Ensino de Ciências. (SANTOS e GRECA, 2006, p. 10).

É necessário que as perguntas de pesquisa, os referenciais teóricos e metodologias escolhidas estejam coerentemente relacionados. Desse modo, não é possível estabelecer uma metodologia sem considerar as hipóteses que alicerçam os problemas da pesquisa e seus objetivos (CARVALHO, 2006, p. 13).

Faremos a seguir uma rápida retomada dos objetivos desta pesquisa e apontaremos suas etapas de desenvolvimento, de modo a esclarecer e justificar a metodologia de análise selecionada, que será apresentada em seguida.

\subsection{O desenvolvimento da pesquisa}

O objetivo desta pesquisa é analisar a utilização da história da ciência na educação científica com o propósito de discutir aspectos empíricos da natureza da ciência (veja seção 1.2.1). Busca-se identificar desafios, obstáculos e conflitos na transposição de conteúdos histórico-epistemológicos para o ensino médio. Pretende-se que os resultados da análise dos dados coletados ao longo do processo possam contribuir em dois âmbitos: primeiro, para a produção do conhecimento acadêmico sobre o uso da história e filosofia da ciência em ambiente escolar. Segundo, espera-se que os resultados possam ser úteis para a elaboração de outras propostas práticas visando a objetivos pedagógicos 
semelhantes. Assim, objetiva-se também contribuir para a melhoria dos processos de elaboração de materiais didáticos para os alunos, na forma de seqüências de atividades didáticas e textos de apoio para o professor.

\subsubsection{A estratégia adotada}

A estratégia metodológica adotada para desenvolver essa pesquisa foi confrontar os desafios previstos a partir dos quadros teóricos utilizados com as dificuldades vivenciadas na construção de um curso piloto e na sua aplicação em sala de aula. Desse modo, as questões metodológicas norteadoras da pesquisa foram desenvolvidas em dois níveis distintos, um teórico e outro empírico, a saber:

1. análise teórica comparativa das exigências didático-pedagógicas e históricoepistemológicas;

2. desenvolvimento de uma parte empírica que compreende a elaboração, acompanhamento da aplicação e análise de um curso piloto para o ensino médio.

\subsubsection{A dimensão teórica da pesquisa}

A dimensão teórica da pesquisa contempla exigências de natureza didáticopedagógicas que tomam como pressuposto a necessidade de transformação dos saberes de referência, no caso sobre a ciência, para o ambiente escolar (CHEVALLARD, 1991; ver capítulo 2). Acrescentam-se a isso os requisitos historiográficos da história da ciência visando evitar distorções (AllChIN, 2004; KRAGH, 1987; MARTINS, L., 2005; MARTINS, R., 2001; WHITAKER, 1979), e as recomendações epistemológicas das pesquisas educacionais (GIL Perez et al., 2001; Lederman, 2007; MCCOMAS et al., 1998; PUMFrey, 1991) apontando para propósitos pedagógicos na formação dos alunos, como tratado no capítulo 1.

A partir da confluência das necessidades desses diferentes campos do conhecimento, estabelecemos teoricamente alguns obstáculos a enfrentar, riscos potenciais a assumir na construção de uma proposta e os dilemas inerentes aos processos de escolha (ver capítulo 2). Esses obstáculos e riscos foram confrontados com os dados obtidos no desenvolvimento da parte empírica da pesquisa. 


\subsubsection{A dimensão empírica da pesquisa}

A parte empírica do trabalho, apresentada neste capítulo, incluiu a elaboração de uma seqüência didática, que constituiu um curso piloto aplicado em uma escola básica. Buscava-se vivenciar as dificuldades e propor possíveis soluções para alguns dos problemas intrínsecos ao uso da história e filosofia da ciência no ambiente escolar. Esta parte empírica está dividida em etapas distintas (que serão apresentadas ao longo deste capítulo):

- selecionar o conteúdo da história da ciência que atenda aos propósitos da pesquisa;

- desenvolver o material para os alunos a ser utilizado nas aulas;

- desenvolver o material de apoio ao professor;

- desenvolver as atividades da seqüência didática que serão aplicadas em sala de aula;

- contatar e apresentar a proposta do curso ao professor de física do ensino médio;

- preparar o professor e dar suporte para a aplicação do curso;

- acompanhar a aplicação do curso e a gravação das aulas em vídeo e tomar notas de campo;

- analisar os dados obtidos.

\subsubsection{Análise dos processos de interação na relação didática}

Uma vez estabelecidos alguns obstáculos, riscos e conflitos ou dilemas a partir do quadro teórico (ver capítulos 1 e 2), partimos para investigar as dificuldades em situação real de sala de aula, constituindo a base empírica da pesquisa. O primeiro grupo de resultados foi estabelecido durante o desenvolvimento do curso piloto, em várias de suas etapas. Foi possível identificar obstáculos estruturais, que serão apresentados e discutidos no próximo capítulo.

$\mathrm{Na}$ análise dos dados obtidos na aplicação do curso piloto desejávamos investigar como se estabelecem as relações entre os sujeitos (incluindo-se aí professor e alunos) e o saber no uso da história e filosofia da ciência em ambiente escolar. Buscamos analisar alguns processos de interação alunos-professor-saber, mediados pelas estratégias pedagógicas propostas, visando entender se, e em que medida, elas contribuíram para atingir nossos propósitos pedagógicos. Além disso, buscamos identificar, ao longo dessas 
análises, como as propostas enfrentavam os desafios identificados durante a elaboração do curso.

Acompanhar o comportamento dos alunos em situações de sala de aula permitiunos avaliar as escolhas feitas para lidar com os obstáculos enfrentados. Buscamos analisar como tais escolhas contribuíram para a "adequada" utilização da história da ciência na escola básica, visando nortear transposições futuras da discussão epistemológica para a sala de aula.

Buscamos avaliar o processo como um todo, porém selecionando situações do curso que esclarecessem ou exemplificassem as questões enfocadas nesta pesquisa. Interessava-nos particularmente entender como os alunos se envolveram com a problemática proposta e se as atividades motivaram a reflexão dos alunos, por exemplo. A questão da pesquisa volta-se, desse modo, ao processo tanto quanto ao produto (ERICSON, 1998).

Trata-se de uma análise voltada a uma situação específica, única, com as características e particularidades do seu contexto de aplicação. Nessa perspectiva, os dados produzidos propiciaram um estudo analítico-descritivo fundamentado por uma metodologia qualitativa de pesquisa. A metodologia escolhida contém traços de um estudo de caso, na perspectiva de que a aplicação do curso ocorreu em um contexto singular e idiossincrático, mas visando resultados capazes de aumentar o conhecimento sobre a questão enfocada e serem extrapolados para outros contextos educacionais.

Tanto os resultados almejados como os dados produzidos indicam a análise de tipo qualitativa como a mais adequada aos propósitos da pesquisa (CARVALHO, 2006, p. 24-9). Apresentaremos na próxima seção algumas considerações sobre a metodologia qualitativa de análise nas pesquisas educacionais.

\subsubsection{Metodologia qualitativa de análise}

A abordagem qualitativa em pesquisas educacionais, como nas demais atividades humanas, traz consigo uma carga de valores, interesses e princípios pessoais que orientam o trabalho do pesquisador, cuja visão de mundo norteia os pressupostos que conduzem sua abordagem investigativa. 
Em educação as coisas acontecem de maneira tão inextricável que fica difícil isolar as variáveis envolvidas e mais ainda apontar claramente quais são as responsáveis por determinado efeito. (LÜDKE e ANDRÉ, 1986, p. 3).

Deve-se perseguir o rigor do trabalho científico recorrendo a critérios que conferem veracidade às informações construídas e permitem minimizar a influência de valores pessoais, seja utilizando as metodologias quantitativas mais tradicionais ou a metodologia qualitativa. Tais critérios são estabelecidos mediante as características de um problema de pesquisa e os objetivos pretendidos para a análise dos dados. Vejamos inicialmente alguns aspectos que caracterizam uma metodologia qualitativa de análise de dados (ERICSON, 1998).

A pesquisa educacional qualitativa supõe o contato direto do pesquisador com seu objeto de estudo, em um trabalho de campo que o coloque imerso no ambiente onde ocorre sua questão de pesquisa (ERICSON, 1998; LÜDKE e ANDRÉ, 1986). De modo geral, as principais características das pesquisas qualitativas são:

- Adotar o ambiente natural como fonte de dados e promover um contato mais direto do pesquisador com o mesmo.

- Utilizar uma diversidade de dados descritivos, como relatos de entrevistas, citações, condições do ambiente, fotografias, entre outros, com o objetivo de caracterizar a situação da maneira mais completa possível.

- Focalizar mais o processo do que o produto.

- Buscar compreender o ponto de vista dos participantes do estudo.

- Analisar e tirar conclusões a partir dos dados.

Além dos documentos extraídos das situações de análise, os dados coletados devem descrever o contexto em que ocorreram as relações interpessoais entre sujeitos e suas interações com o saber. Outros recursos, como transcrição de entrevistas e/ou gravações em vídeos, e as imagens produzidas por ocasião da interação entre pessoas e a questão da pesquisa, podem fornecer informações importantes para a análise. É importante que o pesquisador esteja atento ao maior número possível de elementos que possam interagir com a situação estudada, buscando registrá-los, pois uma variável que poderia mostrar-se trivial em um primeiro momento pode se revelar fundamental ao longo do processo de 
análise. A descrição detalhada da situação investigada permite contribuir para a fidedignidade dos dados obtidos (ERICSON, 1998; LÜDKE e ANDRÉ, 1986, p. 11-12).

Não existe, contudo, uma única abordagem qualitativa para as pesquisas em ensino de ciências. Lüdke e André (1986) realizaram, na década de 1980, um estudo que revelava as principais tendências em metodologias qualitativas que vinham sendo estruturadas e adotadas pelas pesquisas educacionais. As autoras apresentam as características gerais de uma pesquisa qualitativa e depois especificam duas subdivisões: a pesquisa etnográfica e os estudos de caso. Cada uma delas possui os atributos gerais e mais algumas características específicas que as diferenciam.

Carvalho (2006) aponta alguns pontos de confluência e outros de divergência com a visão apresentada por Lüdke e André (1986). Carvalho (2006) relata o aprimoramento metodológico que os grupos atuais de pesquisa em ensino de ciências têm desenvolvido nas últimas décadas. Isso permitiu rever alguns aspectos gerais descritos pelas autoras na década de 1980 e agregar contribuições para esse universo metodológico qualitativo. Por exemplo, enquanto Lüdke e André (1986) apontam o pesquisador como principal instrumento de coleta dos dados, Carvalho (2006) lhe atribui um papel fundamental na seleção do que a câmera de vídeo registrará, pois, em seus estudos, esse é o principal instrumento de coleta. As informações videogravadas são os registros das imagens e das falas que serão posteriormente convertidas em dados e analisadas. Carvalho (2006) descreve benefícios de adotar as gravações em vídeo como dados de pesquisa, como a possibilidade de ver e rever as aulas inúmeras vezes. Essa repetição permite que se identifiquem aspectos que não foram possíveis durante uma observação de campo, dada a complexidade do fenômeno.

Os referenciais teóricos da pesquisa, conhecimentos prévios do pesquisador e sua visão de mundo definem, para Carvalho (2006), o que se quer e o que se pode observar. Para Lüdke e André (1986), os objetivos pretendidos com a análise de dados são estabelecidos pelo quadro teórico da pesquisa, mas é possível que algumas hipóteses a investigar surjam ao longo da análise.

O fato de não existirem hipóteses ou questões específicas formuladas a priori não implica a inexistência de um quadro teórico que oriente a coleta e a análise dos dados. $O$ desenvolvimento do estudo aproxima-se a um funil: no início há questões ou focos de interesse muito 
amplos, que no final se tornam mais diretos e específicos. O pesquisador vai precisando melhor esse foco à medida que o estudo se desenvolve. (LÜDKE e ANDRÉ, 1986, p. 13).

O contato direto do pesquisador com seu objeto de análise permite que ele atue na coleta de dados, identificando e registrando situações que se revelam cruciais para a compreensão do fenômeno educacional. Nesse sentido, ele não se limita a identificar momentos em que teria ocorrido a aprendizagem de certo conteúdo, mas a ele interessa o processo de interação entre sujeitos e saberes que concorreu para momentos de aprendizagem. Nesse momento de interação, o pesquisador pode identificar aspectos imprevistos, levantar hipóteses, questões e mesmo vislumbrar respostas ou soluções para algum problema da pesquisa.

Segundo Carvalho (2006, p. 13-14), estudar os processos de ensino e aprendizagem que ocorrem em sala de aula requer uma compatibilidade indissolúvel entre o problema, o referencial teórico sobre o qual esse problema é entendido e a metodologia utilizada para resolvê-lo. Tal metodologia orientará a coleta de dados de modo a cuidar para que estes respondam com a maior confiabilidade e precisão possível às questões levantadas. Deve-se realizar a descrição cuidadosa da metodologia, mostrando o processo detalhado de coleta e análise de dados, pois isso permitirá que o estudo seja replicado em situações semelhantes, requisito fundamental a um estudo científico.

Outro aspecto fundamental na metodologia qualitativa é a triangulação dos dados, que significa olhar para o mesmo fenômeno a partir de fontes distintas (ERICSON, 1998). Essas fontes podem incluir material escrito pelos alunos, entrevistas com professores e/ou alunos, notas de campo, dados videogravados etc. Comparar notas de campo com dados videogravados e uma análise documental das produções escritas pelos alunos, por exemplo, contribui para aumentar a credibilidade dos dados e da análise.

As situações de pesquisa que requerem uma abordagem qualitativa voltam-se para o processo de interação entre sujeitos e saberes, tanto quanto se preocupam com o produto final de dada situação a investigar. Nesse tipo de estudo procura-se identificar momentos reveladores de como conteúdos e estratégias propostas podem ter contribuído para os propósitos pedagógicos visados. Esses momentos, chamados de episódios de ensino, são então selecionados para um estudo mais detalhado. 
Considera-se um episódio de ensino um momento que envolve a situação que queremos investigar. Pode ser a aprendizagem de um conceito, a situação dos alunos levantando hipóteses num problema aberto, as falas dos alunos após uma pergunta desestruturadora, etc. Ele é parte do ensino, um recorte feito na aula, uma seqüência selecionada que se caracteriza por processos de busca da resposta do problema em questão. A característica fundamental é que seja um ciclo completo, no processo de interação entre sujeitos, mediado pelo objeto do conhecimento. (CARVALHO e GONÇALVES, 2000, p. 73).

Tanto as questões de pesquisa previamente formuladas como as hipóteses que surgem no contato do pesquisador com o objeto de estudo, e também percepções do pesquisador durante a análise de dados, selecionarão e delimitarão os episódios de ensino para compor a análise.

Em análises qualitativas, é importante planejar detalhes da tomada de dados. A observação deve ser controlada e sistemática para que se torne um instrumento válido e fidedigno de investigação científica. No caso de dados videogravados, até a posição da câmara deve ser objeto de reflexão, pois ela deverá focalizar a sala de aula, ou um grupo de alunos, ou o professor, dependendo dos problemas da pesquisa em questão (ERICSON, 1998; CARvalho e GonÇAlves, 2000). É necessário cuidar das questões éticas, solicitando autorização por escrito aos sujeitos envolvidos ou aos responsáveis legais (no caso de alunos menores de idade), pois os dados envolvem a imagem, a fala e os escritos de alunos e professores.

Quando se deseja avaliar o processo de inter-relação dos alunos, professor e determinado saber, é fundamental que as atividades em sala de aula possam favorecer a sua participação e o seu envolvimento. Desse modo, as aulas, cursos, atividades ou seqüência de atividades propostas devem ser elaboradas mediante os referenciais teóricos da pesquisa, o problema que se busca investigar e, também, visando promover a manifestação dos alunos em discussões, debates e trabalhos escritos.

Apresentamos nesta seção considerações sobre a metodologia qualitativa de pesquisa utilizada pelas pesquisas em ensino de ciências. Na próxima seção, faremos a descrição de como procedemos na coleta dos dados para esta pesquisa. 


\subsubsection{Obtenção dos dados no contexto da análise qualitativa}

A criação, a aplicação e a análise do curso piloto configuraram-se como uma experiência que proporcionou a reflexão sobre a didatização dos conteúdos de história e filosofia da ciência ao ambiente escolar. Muitos pontos críticos dessa interface haviam sido apontados pela literatura pertinente e puderam ser explicitados na parte empírica da pesquisa.

Os dados advindos da parte empírica constituem as informações oriundas da aplicação do curso piloto na sala de aula. A análise desse material foi feita levando-se em consideração informações e resultados oriundos da fase de produção/elaboração dos recursos para o curso piloto, assim como da preparação da professora que o ministrou. A confluência dessas distintas informações foi determinante para a definição da problemática que serviria de ponto de partida para a análise dos dados.

Os desafios enfrentados no uso da história da ciência para tratar a natureza da ciência foram definidos na elaboração do curso piloto e contribuíram para orientar a busca e construção dos episódios a serem investigados. A descrição desses desafios são também dados qualitativos e teve o pesquisador como principal instrumento de coleta (ERICSON, 1998).

Os dados coletados nesta pesquisa vieram a partir de três fontes distintas, visando sua triangulação:

- a gravação das aulas em vídeo;

- as respostas escritas pelos alunos aos questionários e avaliações em sala de aula;

- as anotações de campo efetuadas pela pesquisadora durante as aulas.

O planejamento da coleta desses dados levou em conta as hipóteses que alicerçam os propósitos da pesquisa discutidos nos capítulos 1 e 2 e sintetizados na seção 3.1.1 (CARVAlHo, 2006, p. 24-9). Buscamos selecionar situações que elucidaram quanto o curso favoreceu as discussões pretendidas sobre a natureza da ciência, tendo em vista o comportamento dos alunos em situações de sala de aula. Permeando tais discussões, pudemos avaliar como se materializaram algumas das propostas elaboradas para lidar com os desafios vivenciados na elaboração do curso. 
Visitamos a escola antes do início da aplicação, para conhecer a direção, os alunos e verificar as instalações e demais recursos físicos necessários ao planejamento das gravações. Buscou-se posicionar a câmera para focalizar mais os alunos, mas foi possível em alguns momentos focalizarmos também a professora. Isso foi de extrema importância, pois, quando se olha o processo como um todo, importam as interações que ocorrem na sala de aula entre sujeitos e o saber, o modo como as questões foram colocadas, discutidas e problematizadas. Alguns dados foram perdidos durante as gravações devido ao barulho externo à sala de aula. Houve pequenas interrupções em função de falhas técnicas do equipamento, mas isso não prejudicou a qualidade nem a quantidade dos dados.

Utilizamos basicamente como dados as gravações em vídeo (e suas transcrições), mostrando o detalhamento de como o processo de ensino e aprendizagem se desenvolveu em ambiente escolar, as anotações de campo e o material escrito pelos alunos. Buscamos transcrever fielmente as respostas escritas pelos alunos e as suas falas gravadas, bem como as da professora. Não foi realizada nenhuma correção gramatical. Os nomes dos alunos foram substituídos por pseudônimos buscando preservar sua identidade. Os alunos que não conseguimos identificar por estarem fora do posicionamento da câmera, ou atrás de um colega, chamamos de aluno ou aluna ou simplesmente A, nas transcrições que não foram utilizadas para esta tese.

Os dados relativos às transcrições dos vídeos gravados estão organizados em quadros contendo quatro colunas, conforme esquema abaixo:

\section{Quadro 1: Título: Data da aula e número do arquivo}

(visando localizar os trechos selecionados nas gravações).

\begin{tabular}{|l|l|l|l|}
\hline \multicolumn{1}{|c|}{ Turno } & \multicolumn{1}{c|}{ Tempo } & \multicolumn{1}{c|}{ Falas } & \multicolumn{1}{c|}{ Observações } \\
\hline As falas são divididas & Tempo decorrido & Buscamos transcrever & Descrevemos as \\
em turnos & desde o início do & as falas fielmente. & impressões e aspectos \\
apresentados nesta & arquivo transcrito. & Aspectos que & relevantes \\
coluna. Números são & Possibilita termos & queremos destacar & observados. \\
utilizados como & idéia do tempo & estão em negrito. As & Eventualmente \\
referência para as & despendido nos & ocorrências não- & registramos \\
falas que compõem a & diálogos. & verbais estão entre & conclusões \\
análise. & & parênteses e em & preliminares. \\
& & itálico. & Registros em itálico. \\
\hline
\end{tabular}

Os episódios de ensino selecionados para a análise foram denominados "eventos" com o objetivo de diferenciá-los dos episódios históricos, expressão utilizada amplamente ao longo do texto. 
Buscamos registrar ao longo deste capítulo 3 a descrição de todas as etapas seguidas pela pesquisa, de modo a permitir sua réplica para outros contextos teóricos e aplicações empíricas (CARVALHo, 2006, p. 14). Uma vez esclarecidos os objetivos da pesquisa e a metodologia adotada para seu desenvolvimento, coleta e análise de dados, faremos agora a descrição das etapas de elaboração do curso piloto.

\subsection{A elaboração do curso piloto}

Como chegar ao coração dos alunos? Não seria um exagero dizer que esse é o sonho de todo educador. Os professores costumam sentir certo fascínio pelos conteúdos dos seus respectivos campos de especialidade, mas não é possível supor que tais conhecimentos provoquem o mesmo envolvimento nos alunos. Professores de física, de modo geral, ficam maravilhados ao tentar entender a luz, a matéria das estrelas, a imensidão vazia do ínfimo átomo... De que maneiras a humanidade vem tentando explicar o calor de uma vela, o gelo derretendo, as coisas caindo? "A natureza tem horror ao vazio, o homem é uma miniatura do universo, o éter atravessa os corpos transparentes, o átomo é um pudim de ameixas...". Que incrível mergulhar nos mundos que davam sentido a essas idéias.

Mas e o outro? E o aluno? Como conquistá-lo para essas viagens no tempo? Que aspecto do conteúdo poderia motivá-lo? Como abordar esse conteúdo?

Os desafios enfrentados na criação do curso foram além da correta abordagem historiográfica no processo de descontextualização dos saberes de referência para a criação do Saber a Ensinar. Desejávamos envolver o aluno, despertar nele o fascínio pelos conteúdos, tornando sua a problemática pretendida. Naquele momento pareceu-nos que era possível recorrer a duas estratégias pedagógicas para isso, encontrar aspectos do conteúdo possivelmente interessantes para o estudante do ensino médio, e desenvolver atividades didáticas que pudessem ser "sedutoras" do ponto de vista dos alunos.

Depois de estabelecido o objetivo da parte empírica da pesquisa (ver seção 2.4), o quadro teórico ofereceu-nos o "mapa e a bússola" que guiariam nossa empreitada. Mas um caminho só se constrói percorrendo-o, abrindo trilhas na mata e vivenciando os desafios. Assim, temperando as ações com a utopia almejada e tecendo os fios do quadro teórico, fomos em busca de estratégias pedagógicas que materializassem um caminho possível. 
As questões que nos guiaram naquele momento foram: que conteúdo da história da ciência seria adequado aos nossos propósitos pedagógicos? Que aspectos poderiam favorecer as discussões sobre natureza da ciência pretendidas? Que recursos didáticos poderiam conquistar os alunos?

O objetivo adotado para a elaboração do curso piloto era utilizar a história da ciência para promover a discussão e reflexão sobre alguns aspectos selecionados da natureza da ciência. Pretendia-se que ao final do curso o aluno tivesse refletido sobre algumas componentes da natureza da ciência indicadas na seção 1.2.4.

Tendo em vista tal objetivo, partimos para a seleção do tema histórico, dos conteúdos a enfatizar, da elaboração dos materiais e para a criação das atividades pedagógicas. Tais etapas serão descritas nas próximas seções.

\subsubsection{A escolha do tema histórico}

A substituição da teoria corpuscular da luz pela teoria ondulatória no início do século XIX tem sido tratada em diversas situações de ensino como um bom exemplo de revolução científica (LEVITT, 2000; KUHN, 1997). Entretanto, a importância que o conceito de éter luminífero desempenhou nessa disputa histórica nem sempre recebe destaque nas propostas de ensino. Em geral, quando são abordados aspectos históricos desse debate, salienta-se a importância que a matematização de experimentos físicos conferia à teoria ondulatória da luz (LEVITT, 2000, p. 50), e/ou o sucesso explicativo que a teoria ondulatória trazia para alguns experimentos que não eram interpretados satisfatoriamente pela teoria corpuscular (PIETROCOLA, 1993b).

Os complexos processos envolvidos nesse episódio são pouco explorados pela literatura educacional. Tanto entre os defensores da teoria ondulatória para a natureza da luz como entre os corpuscularistas. Havia controvérsias acerca de conceitos, idéias e prescrições metodológicas (CANTOR e HoDGE, 1981).

Discutir certas características que permearam esse episódio histórico pareceu-nos um recurso interessante para promover uma reflexão no ambiente escolar sobre a natureza da ciência. Os conceitos de éter desempenhavam papéis explicativos nas teorias do período e possuíam também pressuposições metafísicas relevantes a considerar (CANTOR e HoDGE, 1981; NeRSESSIAN, 1984). Alguns aspectos da relação entre os conceitos de éter e as 
teorias da luz pareceram-nos interessantes para serem discutidos pelos alunos e envolveriam vários aspectos da natureza da ciência, por exemplo:

- os critérios de cientificidade mudam ao longo da história da ciência;

- há premissas para a aceitação de entes inobserváveis na construção de modelos científicos;

- a observação dos fenômenos sozinha não era suficiente para decidir qual a melhor teoria;

- existe a influência de fatores não-científicos na construção do pensamento científico;

- a natureza não fornece dados suficientemente simples que permitam interpretações sem ambigüidades;

- uma observação significativa não é possível sem uma expectativa preexistente;

- a ciência é uma atividade humana influenciada pelo contexto sociocultural de cada época;

- teorias científicas não podem ser provadas e não são elaboradas unicamente a partir da experiência;

- o conhecimento científico baseia-se fortemente, mas não inteiramente, na observação, evidência experimental, argumentos racionais e ceticismo.

Os experimentos realizados na época motivavam debates sobre a explicação para a natureza da luz, em vez de permitir uma única explicação possível para os fenômenos (CANTOR e Hodge, 1981; Martins, no prelo; Pietrocola, 1993b). Havia praticamente um consenso entre os homens de ciência sobre os problemas de construir teorias baseadas em hipóteses e em entidades inobserváveis. Contudo, era impossível aceitar a teoria ondulatória naquela época sem admitir a existência do éter luminífero. Ainda que isso possa parecer "pouco científico" do ponto de vista atual, pareceu-nos educativo os alunos perceberem que os critérios que os homens de ciência adotam como válidos mudam de acordo com o contexto cultural amplo de cada época. Ademais, muitos especialistas enfatizam a importância do apoio político e material que Fresnel recebeu de Arago na elaboração e defesa de sua teoria ondulatória. Esse pode ser um exemplo da influência de fatores não-científicos na construção da ciência.

Desse modo, num primeiro momento, selecionamos como tema histórico para o curso certos aspectos do debate que envolveu a substituição da teoria corpuscular pela 
ondulatória no início do século XIX. A contribuição de Fresnel nesse episódio e a relação entre o éter luminífero e as teorias da luz seriam pontos centrais a serem explorados.

Uma vez estabelecido o tema histórico a ser abordado, o próximo passo foi selecionar quais os conteúdos específicos que atenderiam aos objetivos pretendidos, sem desconsiderar as exigências didático-pedagógicas da sala de aula. Discutiremos a seguir como tentamos lidar com as seguintes questões: que aspectos deviam ser omitidos e quais seriam imprescindíveis de abordar? Qual o nível de profundidade adequado para a abordagem matemática? Seria possível tratar esse episódio tendo em vista os aspectos da natureza da ciência pretendidos omitindo a matemática? Isso seria uma simplificação ou uma distorção?

\subsubsection{Os conteúdos selecionados}

Iniciamos a elaboração do curso piloto com a preparação de um texto histórico voltado ao professor, tratando do conteúdo que daria embasamento ao curso. Nesse momento surgiu uma questão fundamental e que requereu a inclusão de novos conteúdos além dos pretendidos a priori. Inicialmente, a proposta de abordar os debates que envolveram o papel do éter luminífero na teoria ondulatória da luz no início do século XIX pareceu-nos adequada aos propósitos pedagógicos da pesquisa. Todavia, até que ponto os estudantes do ensino médio possuíam os pré-requisitos necessários para discutir um assunto tão complexo?

Não se deve assumir como pressuposto que o aluno conheça um pouco do processo envolvido na elaboração das teorias ondulatória e corpuscular ao longo da história, tampouco sobre a existência do éter luminífero e seu papel na construção de modelos científicos. Tornou-se imprescindível preparar o aluno para compreender os aspectos a serem problematizados, selecionando alguns momentos da história da óptica anteriores ao debate do século XIX que atenderiam a tal necessidade. O primeiro desafio a enfrentar foi selecionar conteúdos que poderiam preparar o aluno para entender os conceitos físicos envolvidos e as questões epistemológicas da época envolvidas na discussão.

Esse desenvolvimento valeu-se, naquele primeiro momento, de pressupostos teóricos da historiografia da história da ciência que sinalizavam os riscos da pseudohistória (AllChin, 2004; MARTINS, 2004). Por outro lado, para atender as exigências educacionais, foi necessário levar em conta os processos de construção dos saberes 
escolares, especialmente, o Saber a Ensinar (CHEVALLARD, 1991). Entretanto, foi bastante relevante a presença de critérios subjetivos, escolhas "intuitivas" de um conhecimento tácito adquirido ao longo dos anos de docência para lidar com certas questões. Nesse processo fomos guiados por dúvidas inerentes ao ofício do professor, tais como:

- Como abordar o conteúdo histórico-epistemlógico buscando chegar ao coração do aluno?

- Como contribuir para que ele lide com a complexidade da discussão em torno do éter luminífero?

- Como capturá-lo para essa viagem no tempo?

- Como contribuir para que ele se aproprie da problemática?

Já que a opção pelo debate no início do século XIX envolvia entender a luz como partículas de matéria ou ondas em algum tipo de meio material, conhecer um pouco da teoria corpuscular de Isaac Newton e da teoria de tipo ondulatória de Christiaan Huygens poderia contribuir para isso. Seria interessante selecionar algumas informações sobre esse episódio histórico visando preparar o aluno quanto à compreensão dos pontos favoráveis e problemáticos em ambas as teorias. Pareceu-nos que tal episódio também permitiria introduzir a discussão sobre o éter luminífero de modo que pudesse ser compreensível ao aluno do ensino médio.

Certos aspectos dos dois episódios selecionados (elementos das teorias propostas no século XVII por Newton e Huygens para a natureza da luz e a aceitação da teoria ondulatória no início do século XIX) ainda pareciam complexos, exigindo a intermediação de instrumentos para discutir a natureza da luz, como o "famoso fenômeno das cores", nome pelo qual a dispersão da luz branca pelo prisma era conhecida no século XVII. Pareceu-nos que seria interessante introduzir o tema recorrendo a algo que fosse próximo do universo cognitivo dos alunos, que os aproximasse da problemática e os envolvesse com o conteúdo. Surgiu a idéia de abordar a relação entre a natureza da luz e a visão, num contexto histórico em que houvesse o mínimo possível de interferência de equipamentos, instrumentos de medida e outros intermediários entre o homem e o fenômeno a ser observado. As teorias elaboradas por alguns filósofos gregos pareciam atender a esses propósitos. Entender um pouco das propostas dessas teorias não requer conhecer ferramentas matemáticas sofisticadas. Além disso, seria uma oportunidade para mostrar como o homem utilizou diferentes métodos na tentativa de explicar a natureza ao longo de 
sua história. Um benefício adicional seria levar aos alunos algumas informações sobre as diferenças entre o pensamento mítico e o pensamento racional, buscando fugir das abordagens tradicionais e preconceituosas.

O conteúdo do curso piloto ficou estruturado em três episódios:

Episódio I: Um pouco sobre a luz na Antiguidade grega

1. O que é a luz? Como vemos o mundo?

2. Explicações muito antigas: mitos e filosofia.

3. A luz para os atomistas.

4. Empédocles e o raio visual.

5. Aristóteles e a qualidade dos corpos transparentes.

6. Pensando sobre a diversidade de teorias.

Episódio II: A natureza da luz para alguns pensadores do século XVII

1. Revisão de fenômenos ópticos necessários à compreensão dos próximos assuntos tratados no curso: reflexão, refração e dispersão da luz.

2. O fenômeno das cores.

3. Huygens e o movimento no éter.

4. Newton e a possibilidade corpuscular para a luz.

5. A imagem da ciência no século XVIII.

Episódio III: As teorias da luz e o éter luminífero no início do século XIX

1. Revisão de alguns fenômenos ópticos: sombras e difração; superposição e interferência.

2. O vazio e a importância do éter na teoria ondulatória.

3. Rompendo com a tradição corpuscular.

4. Os corpuscularistas e o prêmio de Fresnel.

5. O apoio de Arago.

6. A teoria de Fresnel e a aceitação da teoria ondulatória.

Apresentando as idéias de alguns filósofos gregos, enfocamos a relação “observação da natureza e a elaboração de hipóteses explicativas para os fenômenos". Questionamos a observação neutra do mundo natural e enfatizamos como as concepções 
das diferentes escolas de pensamento fundamentavam as explicações de seus filósofos sobre os fenômenos naturais (veja textos para os alunos no Apêndice C).

Os experimentos com prisma realizados por Newton permitiram refletir sobre a intermediação de instrumentos na observação dos fenômenos naturais, mostrando que não basta observá-los, mesmo com "recursos tecnológicos", para elaborar teorias que sejam consensuais. Pudemos argumentar que os filósofos naturais admitiam pressupostos teóricos na elaboração de hipóteses explicativas. $\mathrm{O}$ debate entre a teoria de tipo ondulatória de Huygens e a teoria corpuscular de Newton mostrou que há pontos favoráveis e limitações nas teorias científicas.

Finalmente, no terceiro episódio, chegamos ao propósito inicial: rever os aspectos epistemológicos pretendidos, discutindo a problemática dos entes inobserváveis na elaboração de teorias científicas; mostrar que o modo de fazer ciência muda ao longo da história; ponderar que há a influência de fatores não-científicos na construção do conhecimento, além de outras contribuições, que podem ser percebidas quando se analisam o planejamento da sequiência didática (Apêndice C.1) e os textos para os alunos (Apêndice C.2).

Esses três episódios foram selecionados buscando atender aos nossos propósitos pedagógicos. Outros momentos da história da óptica poderiam ter sido selecionados? Claro que sim. A articulação que foi dada ao tema é apenas uma entre tantas possibilidades. Sabemos que nossa escolha excluiu momentos relevantes da história da óptica como a construção de instrumentos ópticos e as grandes contribuições dos árabes ocorridas durante a Idade Média, destacando Al-Hazen, por exemplo. Abordar esse período permitiria criticar a visão corrente de que a Idade Média teria sido a "idade das trevas", além de destacar a participação de diversos povos na construção da ciência.

Optamos por estabelecer um recorte bem delimitado de cada um dos três episódios, mas utilizar algum recurso que permitisse apresentar uma visão panorâmica de sua localização ao longo da história. Desse modo, fizemos breve apresentação factual de alguns acontecimentos durante a Idade Média e ao longo do século XVIII. Essas duas pequenas sínteses tinham dois objetivos: mencionar algumas contribuições árabes para óptica durante o Medievo e relatar brevemente a relevância da metodologia newtoniana ao longo do século XVIII, preparando os estudantes para compreenderem alguns aspectos tratados no terceiro episódio. 
Conforme discutimos no capítulo 1, adotamos a perspectiva historiográfica da história da ciência, que defende o severo recorte de seus episódios, seus temas e suas questões para a elaboração de narrativas. Tais recortes foram obedecidos na abordagem dos três episódios tratados, contudo, consideramos que os dois relatos factuais de certos fatos relevantes entre eles poderiam ser úteis para permitir melhor compreensão do tema por parte dos estudantes. Buscou-se mediar as duas exigências: as da historiografia da história da ciência, perseguindo uma abordagem crítica dos fatos, e as necessidades educacionais do nível de profundidade adequado ao ensino médio. Essas breves narrativas factuais da história da ciência ficaram restritas a duas "pontes" entre os períodos, deixando claro que era apenas uma visão superficial. Não se trata de uma reconstrução racional, mas apenas mencionar alguns fatos relevantes ligados ao tema estudado, ocorridos fora dos recortes históricos adotados.

É importante destacar que o resultado dessa versão histórica não pode ser considerado como um trabalho na área de história da ciência, nem é esse o objetivo desta pesquisa. Os textos para o professor (Apêndice A) e para os alunos (Apêndice C) configuram-se como Saber a Ensinar (CHEVAlLARD, 1991). Eles pretendem trazer o conteúdo histórico selecionado para o ambiente educacional, colocando elementos que dão subsídios para a condução da seqüência didática.

O texto para o professor traz mais informações que os textos dos alunos. Incluímos, por exemplo, uma noção das idéias de Platão sobre a luz, aspectos do corpuscularismo de Gassendi e elementos da teoria cartesiana sobre a natureza da luz, que não foram abordados com os alunos. Além disso, o conteúdo apresentado ao aluno é tratado com mais profundidade no texto para o professor. Acreditamos que ele necessita saber de mais aspectos que influenciaram o desenvolvimento das teorias sobre a natureza da luz de Huygens e Newton, por exemplo, para poder apresentá-las aos alunos, além de entender que ocorreram outros importantes debates e desenvolvimentos na óptica do século XVII.

O texto histórico para o professor (Apêndice A) apresenta a linha condutora do curso e traz o conteúdo a ser tratado em cada bloco temático, ressaltando as questões acerca da natureza da ciência. Foi pensado para ser complementado pela bibliografia necessária elencada para cada tema abordado. Os alunos receberam uma versão mais sucinta, com menor número de informações e mais diretamente ligada às atividades desenvolvidas em sala de aula (Apêndice C). 


\subsubsection{Pressupostos para a preparação do curso piloto}

Durante os quatro meses que antecederam o curso, tínhamos reuniões semanais com a professora que iria aplicá-lo, quando apresentamos a proposta, o conteúdo e os objetivos da pesquisa. Discutimos questões éticas e solicitamos a autorização da direção da escola e dos pais dos alunos para gravação e utilização das imagens na pesquisa. Além disso, a professora falou-nos um pouco da escola, dos alunos e alguns de seus hábitos. Perguntamos também sobre os conteúdos de física que os alunos haviam estudado, o que necessitaria de uma revisão e ainda conteúdos de óptica e ondas que eles não conheciam. Todas essas informações foram importantes na seleção de conteúdos, na elaboração dos textos e na construção das atividades, conforme será discutido nas próximas seções.

O curso piloto foi aplicado em uma turma do terceiro ano do ensino médio em uma escola pública na zona sul da cidade de São Paulo. Tal escola trabalha com o método modular de disciplinas, que consiste em organizar as disciplinas em períodos de dias subseqüentes, colocando o total de aulas do bimestre de cada disciplina em um único bloco. Utilizamos 20 horas-aula, com duração de 50 minutos cada, constituindo um módulo de 10 dias úteis com aulas duplas, em setembro de 2007. Havia 43 alunos matriculados, mas apenas 38 assistiam às aulas e freqüentavam a escola.

As características da escola onde o curso foi aplicado e seu sistema modular de disciplinas influenciaram alguns pressupostos na elaboração do curso piloto. Por exemplo, não era possível planejar atividades que requisitassem certo tempo entre uma aula e outra, como, realizar pesquisas, preparar seminários etc. Outro dado relevante foi o fato de os alunos não terem o hábito de leitura e raramente fazerem lição de casa, portanto, não se poderia contar com leituras fora da classe. Tiveram um curso de física cujos únicos recursos didáticos eram: a lousa, o giz e a criatividade da professora. Eles nunca utilizaram materiais didáticos com ilustrações ou outros recursos visuais, e aprenderam rudimentos da óptica geométrica com o que a professora conseguia representar na lousa. Desse modo, incluímos algumas imagens e representações de alguns fenômenos ópticos nas apresentações em slides que antecediam a leitura dos textos.

\subsubsection{Desenvolvimento dos textos para os alunos}

O conteúdo do curso piloto para os alunos foi desenvolvido em oito pequenos textos e um roteiro para uma peça de teatro. Buscou-se respeitar a metodologia prescrita 
pela nova historiografia da ciência (MARTINS, L., 2005), sem perder de vista que se trata da elaboração de um saber escolar, e não de um estudo especializado voltado para os historiadores da ciência.

Os textos do curso piloto para os alunos foram os seguintes (Apêndice C):

Texto 1: A filosofia e as explicações para o funcionamento da natureza.

Texto 2: Um pouco sobre a luz na Antiguidade grega.

Texto 3: O frágil bebê que se tornou o grande filósofo natural.

Texto 4: Fim do século XVII: corpúsculos ou pulsos no éter?

Texto 5: Os pulsos no éter de Huygens.

Texto 6: A teoria corpuscular de Newton.

Texto 7: A luz e o Século das Luzes.

Texto 8: O éter e a natureza da luz (Roteiro para teatro).

Texto 9: As teorias da luz e o éter luminífero no início do século XIX.

A utilização desse material na sala de aula ocorreu junto com a seqüência de atividades didáticas apresentada na próxima seção. Os estudantes liam os textos junto com a professora (visando garantir que todos os lessem) somente depois de terem realizado algum tipo de interação com seu conteúdo. Desse modo, cada texto trazia uma sistematização das idéias que haviam sido problematizadas anteriormente por meio de diferentes estratégias pedagógicas.

Buscou-se promover o contato do aluno com o conteúdo selecionado da natureza da ciência tanto nos três episódios históricos como utilizando diversos recursos educacionais. Isso permitia ao aluno rever os conhecimentos sobre a ciência em distintos contextos históricos, refletindo sobre cada aspecto em diferentes perspectivas. Como as aulas da seqüência didática ocorreram em 10 dias subseqüentes, a quantidade de informação possível de ser trabalhada é limitada, pois é necessário dar certo tempo ao aluno para rever e amadurecer os conteúdos e discussões. Assim, buscamos desenvolver textos e atividades que propiciassem retomar certos problemas já levantados anteriormente para promover diversos momentos de interação entre o aluno e determinado conteúdo do Saber a Ensinar (Apêndice C). Tínhamos a intenção de favorecer o gradual amadurecimento dos estudantes 
com relação aos conteúdos sobre a natureza da ciência, além de permitir uma revisão desses conceitos aos alunos que não os tivessem compreendido.

As questões colocadas ao final dos textos pretendiam ser provocativas, criando conflitos, levantando polêmicas e levando os alunos a refletir sobre os temas tratados (Apêndice C.1). Não são questões meramente interpretativas, ou seja, não se espera que os estudantes encontrem todas as respostas no texto, mas que reflitam, questionem, discordem e argumentem a partir dele, colocando o seu ponto de vista. As expectativas acerca da profundidade de tais reflexões, bem como o nível de argumentação esperado, eram adequadas ao contexto escolar do ensino médio e ao grau de escolaridade dos alunos.

Optamos por questionar um mesmo aspecto do conteúdo sobre a ciência de modos distintos em um mesmo texto. Colocamos duas questões diferentes sobre um mesmo aspecto buscando levar o aluno a repensar sua opinião, com o intuito de reforçar sua interação com cada problemática levantada. Tal estratégia mostrou-se produtiva com a maioria da sala, embora alguns alunos tenham percebido tratar-se da mesma questão.

\subsubsection{Desenvolvimento da seqüência de atividades didáticas}

Desenvolvemos diferentes atividades didáticas para o curso, buscando torná-lo interessante para o estudante do ensino médio. Nosso intuito era envolver o aluno com o conteúdo, provocando-o a tomar para si os problemas levantados, tornando-o partícipe do processo. Como dissemos anteriormente, levamos em consideração o contexto da escola que trabalha com o sistema modular, em que as aulas acontecem em dias consecutivos. Tais atividades estão descritas no planejamento do curso no Apêndice $\mathrm{C}$ e aqui serão apresentadas e comentadas sucintamente:

1. Colocando na linha do tempo.

2. Quebra-cabeça com o texto 1.

3. Slides com as teorias da luz na Antiguidade.

4. Texto 2 com discussão das questões em grupo.

5. Quebra-cabeça com o texto 3.

6. Imagens e representações de fenômenos ópticos em slides.

7. Demonstração experimental de fenômenos ópticos.

8. Slides com teorias para a natureza da luz no século XVII.

9. Texto 4 e resolução das questões. 
10 Textos 5 e 6 para a preparação do debate.

11. Debate entre grupos defendendo teorias concorrentes.

12. Quebra-cabeça com texto 7.

13. Apresentação de teatro.

14. Demonstração experimental de fenômenos ópticos.

15. Animação Dr. Quantum - trecho inicial.

16. Slides com conteúdo do episódio III.

17. Texto 9 com discussão das questões em grupo.

18. Avaliação com consulta inspirada na "prova operatória".

19. Festival cultural.

A seguir, explicitaremos cada uma dessas atividades:

1. A primeira atividade do curso foi a linha do tempo. Foram distribuídos 19 cartões aos alunos com eventos históricos bem conhecidos e a imagem de filósofos, filósofos naturais e cientistas, sendo bem poucos deles conhecidos dos alunos. Abaixo de cada ilustração havia o nome do pensador e uma "pista" da época em que viveu (Apêndice D). Os alunos foram organizados em grupos e deveriam colocar os 19 cartões em uma seqüência temporal. A professora confrontou as diferentes respostas e apresentou a linha do tempo aos estudantes.

Tal linha cronológica de 1300 a.C. até 2000 foi representada em uma faixa de seis metros, com imagens de filósofos, pensadores e cientistas ligados à história da ciência. Imagens de alguns filmes históricos foram utilizadas para ilustrar cada período, como Tróia, Alexandre, O nome da Rosa, Carlota Joaquina, entre outros. Esse recurso visual pretendeu oferecer ao aluno uma visão panorâmica da localização histórica dos episódios tratados ao longo do curso (veja reprodução da linha cronológica no Apêndice D). Ela foi utilizada como estratégia para lidar com o dilema da extensão versus profundidade: embora a abordagem adequada da história da ciência prescreva a necessidade do recorte para minimizar os riscos da pseudo-história, pareceu-nos não só importante, mas necessário tornar claro para o aluno a dimensão temporal que separava os três episódios. Abaixo da linha cronológica foi colocada uma faixa de papel em branco para que os alunos trouxessem contribuições durante o curso, com eventos históricos, obras literárias, compositores, pensadores de várias áreas etc. A professora de biologia utilizou alguns 
dados contidos na faixa e incluiu outros personagens sobre os quais estava estudando com os alunos.

Em um curso de maior duração, os próprios alunos poderiam ir construindo a linha do tempo, mas, devido ao pouco tempo disponível para desenvolver o tema, optamos por realizar uma pequena atividade no início do curso e levá-la pronta. Uma das vantagens de construir a linha do tempo com os alunos é poder incluir outros temas de interesse do grupo, como pintores, músicos, poetas, eventos marcantes, além de propiciar um trabalho conjunto com outras disciplinas, como história, literatura ou filosofia, por exemplo.

2. A professora comentou sobre a linha do tempo com os alunos, enfatizando ao final o conteúdo do texto 1: "A filosofia e as explicações para o funcionamento da natureza" (Apêndice C). Ela distribuiu tal texto aos estudantes recortado em parágrafos para que estes o reconstruíssem. Depois disso, a professora realizou a leitura com toda a sala.

3 e 4. As teorias sobre a luz na Antiguidade foram apresentadas utilizando primeiramente os slides, para depois os alunos lerem o texto 2: "Um pouco sobre a luz na Antiguidade grega", e responderem às questões.

5. Entre os episódios I e II os alunos receberam o texto 3: "O frágil bebê que se tornou o grande filósofo natural" recortado em parágrafos. Esse texto traz breve biografia de Isaac Newton e foi usado como lição de casa no intuito de ir ambientando o aluno ao século XVII. Tal texto menciona aspectos da vida de Isaac Newton que em geral despertam a curiosidade dos estudantes, como, por exemplo, a surra que deu em um colega maior e aparentemente mais forte e os seus trabalhos na universidade esvaziando urinóis em função da pouca ajuda financeira que recebia de sua mãe. $O$ texto comenta também o grande empenho de Newton no estudo da alquimia, das profecias bíblicas e outros interesses pouco "científicos" do ponto de vista atual. A professora realizou a leitura com os estudantes em sala e respondeu a algumas questões, o que confirmou a curiosidade dos estudantes pelo conteúdo e acabou por levar os alunos a pensar no século XVII.

6 e 7. A revisão dos fenômenos reflexão e refração da luz foi feita utilizando imagens e representações em slides, enquanto a dispersão da luz foi também demonstrada experimentalmente utilizando um prisma e a luz do retroprojetor dimensionada adequadamente com auxílio de um feltro preto. A discussão sobre o fenômeno das cores 
permitiu tratar da utilização de "instrumentos" no estudo dos fenômenos naturais e sobre as diferentes interpretações que os filósofos naturais elaboravam.

8. A apresentação das teorias corpuscular e de tipo ondulatória foi iniciada utilizando slides, e uma demonstração experimental usando bolas de gude e duas lanternas ilustrou o encontro dos raios luminosos em ambas as teorias. Os alunos "visualizaram" um dos argumentos utilizados no período para criticar a teoria corpuscular: como as partículas de luz passam umas pelas outras sem interagir entre si?

9. Depois da discussão de todo o conteúdo do episódio II, os alunos realizaram a leitura do texto 4: "Fim do século XVII: corpúsculos ou pulsos no éter?" e a resolução das suas questões.

10. A preparação para a atividade do debate incluiu a correção das questões do texto 4, a leitura dos textos 5: "Os pulsos no éter de Huygens" e 6: "A teoria corpuscular de Newton", e uma parte de uma aula destinada aos grupos para se reunirem e prepararem suas argumentações.

11. Na atividade do debate cada grupo defendeu uma teoria para a natureza da luz: a teoria de tipo ondulatória de Huygens e a teoria corpuscular de Newton. Os grupos apresentaram seus pontos de vista, buscando argumentar com exemplos de fenômenos naturais o que cada teoria explicava melhor, além de apontar limitações na teoria rival. Tal atividade possibilitou aos alunos vivenciar uma disputa entre idéias, simulando uma das características da prática científica, em que cada grupo busca argumentos que corroborem suas idéias e refutem as teorias rivais.

12. O texto 7 sobre o século XVII: "A luz e o Século das Luzes" foi entregue recortado em parágrafos para que os alunos o reconstruíssem em casa. A professora comentou que seria importante a leitura, para compreender aspectos da peça de teatro que seria apresentada na aula seguinte.

13. A peça, O éter e a natureza da luz, foi encenada por um grupo de alunos da sala que receberam o texto com o roteiro cerca de um mês antes de o curso iniciar. Sua função no curso piloto era envolver os estudantes no tema a ser tratado no episódio III, principalmente com relação ao éter luminífero. Trata-se de um recurso didático inspirado nos episódios estudados enfatizando aspectos da natureza da ciência. Utilizamos alguns fatos históricos para criar uma ficção, visando rever e enfatizar o conteúdo tratado no curso 
e discutir sobre o éter luminífero. A opção por essa atividade requereu tomar decisões e assumir alguns riscos. Como o curso ocorreria em dias consecutivos, o período era muito pequeno para os alunos estudarem o roteiro e ensaiarem a apresentação durante o próprio curso. No bimestre anterior ao módulo em que a seqüência didática seria aplicada, a professora apresentou a proposta do teatro para a classe e perguntou quais alunos estavam interessados em participar. Fizemos uma reunião com esses alunos explicando que nesse momento eles decorariam as falas, mesmo sem compreender os aspectos conceituais envolvidos no texto. Essa compreensão viria durante o curso. Tais alunos ensaiaram o texto e criaram os recursos sugeridos, como a abertura, o cenário e o figurino. Além disso, incluíram uma cena introdutória, que não estava prevista no roteiro, com a finalidade de mais alunos poderem participar, já que os interessados eram em maior número do que os personagens previstos. Após a apresentação, a professora reuniu toda a sala para uma discussão sobre os assuntos tratados na peça e perceber qual o impacto e possíveis resultados dessa estratégia utilizada.

14. Realizamos a demonstração experimental de fenômenos ópticos utilizando a luz do datashow e cartões opacos colocados entre ela e o anteparo (parede da sala). Utilizando um cartão com figuras geométricas recortadas, um cartão com pequena fenda no centro e outro cartão com fendas duplas. Revisamos os conceitos de sombra, difração e interferência da luz.

15. Utilizamos o trecho inicial da animação Dr. Quantum que ilustra o experimento da dupla fenda que compara os fenômenos da difração e interferência luminosa, mediante concepções ondulatória e corpuscular para a luz. ${ }^{9}$ A animação apresenta nos primeiros 1 minuto e 45 segundos uma situação em que um feixe de bolinhas atiradas por um canhão passa inicialmente por uma fenda, atingindo um anteparo do outro lado, desenhando nele uma barra vertical proporcional ao tamanho da fenda. Depois, as bolinhas passam por duas fendas paralelas e desenham proporcionalmente as duas fendas paralelas no anteparo. Depois disso, é apresentada uma situação em que as bolinhas são substituídas por ondulações na água. A frente de ondas desloca-se na água e encontra primeiro o obstáculo com uma fenda onde ocorre a "difração", que desenha determinado padrão no anteparo. Em seguida a frente de onda encontra a dupla fenda, e é possível acompanhar a "difração"

\footnotetext{
${ }^{9}$ Tradução para o português: $\operatorname{Dr}$ Quantum - Fenda Dupla. Utilizamos apenas os primeiros 1 min $45 \mathrm{~s}$, disponível em: http://br.youtube.com/watch?v=lytd7B0WRM8.
} 
em cada uma das fendas. A animação destaca a superposição das frentes de onda que se espalham a partir dessas duas fendas no espaço entre elas e o anteparo, fazendo surgir regiões de interferência construtiva e destrutiva que "desenham" as franjas claras e escuras ao atingirem o anteparo. Por meio de analogias entre bolinhas e corpúsculos, e as ondas na água e na luz, o personagem da animação, Dr. Quantum, explica por que uma concepção corpuscular não explica a difração.

16. O conteúdo histórico do episódio III foi apresentado em slides incluindo também representações dos fenômenos físicos envolvidos, para auxiliar na compreensão das limitações da teoria corpuscular na explicação do fenômeno óptico da interferência luminosa. Optamos por não incluir aspectos matemáticos de ambas as teorias, buscando "compensar" essa deficiência com recursos visuais, como a animação da fenda dupla. Enfatizamos o papel do éter no período para a aceitação da teoria ondulatória e aspectos do apoio político de Arago a Fresnel.

17. Os alunos realizaram a leitura do texto 9: "As teorias da luz e o éter luminífero no século XIX”, e a discussão das questões abertas em grupo. A professora fez a correção dessas questões, a sistematização do episódio III e uma revisão do conteúdo do curso. Orientou os estudantes para que trouxessem todos os textos na aula seguinte, pois a avaliação final seria feita com consulta.

18. A avaliação final foi realizada individualmente com consulta e inspirada na prova operatória, concebida como mais um recurso que favorece o aprendizado (RonCA e TERZI, 1993). Buscou-se que a avaliação fosse coerente com as estratégias de ensino utilizadas até então, com questões abertas e, na medida do possível, com as respostas não explícitas no texto. $\mathrm{O}$ aluno teria a oportunidade de rever todo o conteúdo, refletir, elaborar seu ponto de vista e construir sua argumentação. Buscamos contribuir para o desenvolvimento dessa competência ao longo do curso nos três episódios trabalhados.

19. Quando elaboramos o planejamento pedagógico do curso, reservamos um dia útil (duas horas-aula) antes da avaliação final para um revisão geral ou para atender a possíveis imprevistos. O curso transcorreu conforme o previsto, então surgiu a idéia de propor uma atividade diferente. A professora consultou a classe se preferiam realizar a aula de revisão, releitura dos textos, ou se gostariam de realizar um "concurso cultural". Os alunos inscrever-se-iam voluntariamente para apresentar produções culturais voltadas, necessariamente, ao conteúdo do curso. As três melhores produções receberiam um prêmio 
surpresa (que seriam caixas de bombons). Toda a sala optou pela atividade cultural. Antecipamos a avaliação final em um dia e reservamos a última aula do curso para o concurso. Os alunos cantaram paródias, contaram histórias e uma aluna recitou uma poesia. O resultado superou as expectativas com um clima de cooperação, motivação e alegria de toda a turma. Assim, optamos por distribuir os bombons para todos os alunos. $\mathrm{Na}$ ocasião em que apresentávamos esse curso piloto desenvolvido para esta pesquisa em um congresso internacional, ${ }^{10}$ uma pesquisadora comentou que a atividade configurou-se um "festival cultural" e não um concurso. ${ }^{11}$ Ela inclusive apontou que os resultados educacionais pareciam ter sido mais produtivos tendo em vista o festival ocorrido do que a proposta do concurso. Decidimos incorporar essa correção, pois apontava para uma estratégia pedagógica menos competitiva e mais colaborativa entre os alunos.

O curso foi construído de modo que algumas idéias foram se estruturando e adquirindo aos poucos maior nível de complexidade. Por exemplo, a reflexão proposta no episódio I sobre observação e explicação dos fenômenos naturais, mais os conceitos científicos e o conteúdo histórico-filosófico abordados no episódio II, sobre o século XVII, foram indispensáveis para questionar: seriam argumentos puramente experimentais que tornaram a teoria corpuscular hegemônica durante o século XVIII? Essa idéia surgiu nas discussões iniciais sobre o episódio II, na apresentação em slides, foi sistematizada no texto 4 , retomada nos textos 5 e 6 , permeou implicitamente momentos do debate, e foi finalmente "esclarecida" no texto 7.

Buscamos criar essa seqüência didática de modo a favorecer repetidas vezes o contato entre o aluno e cada aspecto emblemático do conteúdo. Cada aspecto pretendido da natureza da ciência, por exemplo, foi problematizado nos três episódios e em estratégias pedagógicas distintas (Apêndice C). A relação entre a observação dos fenômenos naturais e a elaboração de hipóteses explicativas, por exemplo, surge de modo provocativo em três episódios:

- quando discutimos as teorias de Leucipo, Empédocles e Aristóteles para a visão;

\footnotetext{
${ }^{10}$ FORATO, Thaís C. M.; MARTINS, R. A.; PIETROCOLA, M. The nature of science at physics teaching: a study of luminiferous ether on nineteenth century. In: Proceedings of International Conference on Physics Education, Marrakesh: El Watanya Marrakesh, 2007. v. único, p. 213-213.

${ }^{11}$ Profa. Dra. Glória Queiroz, da UFRJ-RJ-Brasil.
} 
- no episódio do século XVII, quando os alunos observam a dispersão da luz em um prisma e apresentamos os debates entre Newton e seus contemporâneos sobre a explicação discordante para o fenômeno;

- no início do século XIX, ao apresentarmos os fenômenos da difração e interferência luminosa e as dificuldades de sua explicação utilizando a teoria corpuscular.

Além de buscarmos retomar a questão da observação versus hipóteses em diferentes episódios, ela foi também abordada durante distintas estratégias pedagógicas, por exemplo:

- na visualização das demonstrações experimentais dos fenômenos e sua discussão com apoio de apresentação em slides;

- nos textos para a sistematização de cada episódio (optamos por realizar a leitura da maioria dos textos durante a aula para garantir que os alunos os lessem);

- na evidente apropriação dessa questão no debate realizado pelos alunos;

- na abordagem no teatro;

- na pergunta recorrente nos questionários que os alunos respondiam em cada episódio;

- em sua problematização na avaliação final que, por ser realizada com consulta, é mais um recurso que permite ao aluno refletir e elaborar respostas aos problemas levantados (RONCA e TERZI, 1993).

Essa repetição pretendia propiciar o contato do aluno com a problemática em vários momentos, permitindo-lhe rever seu posicionamento anterior, acrescentando informações, reforçando os aspectos conceituais e amadurecendo sua visão sobre a construção histórica de algumas teorias da luz.

A elaboração dessas atividades levou em conta as limitações dos alunos quanto aos pré-requisitos conceituais da física, da história e da filosofia da ciência necessários para o desenvolvimento do conteúdo. Além disso, as características particulares daquele microambiente escolar, como o sistema modular com aulas em dias consecutivos, restringiu o tipo de recursos didático-pedagógicos que se podem propor. Isso limitou um pouco a diversidade das atividades, por exemplo, optamos por apenas demonstrar algumas experiências em vez de deixar que os alunos as executassem para que isso não tomasse 
muito tempo das aulas; a linha do tempo foi levada pronta em vez de os alunos construírem-na. Nesse contexto, as atividades do debate e do teatro, por exemplo, requereram assumir certos riscos, pois foi necessário disponibilizar com antecedência certos textos para apenas um grupo de alunos.

A aplicação desse curso em outros contextos poderia incluir estratégias que exigem tempo de preparação por parte dos alunos, como a realização de pesquisas, elaboração de seminário etc.

\subsubsection{Material disponibilizado}

A escolha dos recursos materiais utilizados durante o curso também foi objeto de reflexão, já que devem estar adequados e serem acessíveis ao contexto educacional a que se destinam: o ensino médio de uma escola pública.

O grupo de pesquisa Nupic - Núcleo de Pesquisa em Inovações Curriculares ${ }^{12}$-, onde esta pesquisa se desenvolveu, é um núcleo de pesquisa em ensino de ciências e que realiza, também, a elaboração, aplicação, análise e disponibilização de atividades didáticas para o ensino de ciências. Vinculado ao Lapef - Laboratório de Pesquisa em Ensino de Física da Faculdade de Educação da $\mathrm{USP}^{13}$-, é composto por professores e estudantes de graduação e pós-graduação e por professores da rede pública do Estado, desenvolvendo, inclusive, material didático e cursos de formação continuada para professores. Entre os recursos de ensino produzidos estão hipertextos, textos, vídeos, objetos de aprendizagem virtual, apresentações em slides e clipes de vídeo. Na época do desenvolvimento desta pesquisa, o Nupic contava com um projeto de inovação curricular da Fapesp (nº 2003/00146-3), que fornecia o material para ser usado nas escolas públicas, inclusive cópias dos textos para os alunos, recursos tecnológicos e demais demandas pertinentes à pesquisa.

Independentemente dos recursos disponíveis, o trabalho do Nupic inclui a orientação para utilização de inovações em atividades pedagógicas. Isso objetiva contribuir para a democratização do uso de estratégias e materiais na educação, bem como criar demandas para orientar a aplicação de verbas repassadas pelo governo do Estado às escolas

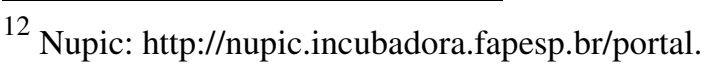

${ }^{13}$ Lapef: http://www.lapef.fe.usp.br/.
} 
públicas. Portanto, buscamos atender a ambas as exigências: utilizar, na medida do possível, inovações educacionais e, ao mesmo tempo, selecionar recursos que pudessem ser acessíveis a outras escolas públicas que forem aplicar esse curso e desenvolver novas propostas.

A sequiência didática que foi aplicada utilizou em algumas aulas a televisão e o retroprojetor que a escola possuía e o Lapef forneceu o datashow para facilitar o uso de apresentações em slides. Essas apresentações poderiam ter utilizado os computadores da sala de informática para a projeção dos slides ou o PCTV, que toda escola pública de São Paulo recebeu em época recente, ${ }^{14}$ além de um DVD player, que a maioria das escolas públicas de São Paulo já tem. ${ }^{15}$

Para as outras escolas públicas que não possuem nenhum desses equipamentos, a proposta do Nupic é originar e orientar a demanda por recursos tecnológicos. Busca-se criar a necessidade de investimentos, disponibilizando no site o material didático já elaborado, esclarecendo as atividades desenvolvidas e todo o planejamento que dá apoio ao professor na aplicação dos cursos, inclusive quanto à utilização de equipamentos.

Os equipamentos utilizados foram a televisão, o retroprojetor e o datashow. O material usado e fornecido para a aplicação do curso piloto (Apêndice C) vinculado a esta pesquisa compreende:

- textos da bibliografia para o professor;

- textos para o aluno;

- apresentação em slides para as aulas;

- o roteiro para o teatro envolvendo o tema histórico;

- linha cronológica de 1,0 m x 6,0 m a ser afixada na parede da sala;

- cartões com pensadores e eventos históricos;

- lanternas, bolas de gude e prisma acrílico.

\footnotetext{
${ }^{14}$ O PCTV é uma ligação do computador com a televisão que permite que esta funcione como monitor de computador.

${ }^{15}$ Veja descrição da utilização dos recursos nas aulas no Apêndice C.1.
} 


\subsubsection{Avaliação}

A avaliação realizada durante o curso piloto teve duas finalidades: atender aos requisitos pedagógicos e administrativos da unidade de ensino e fornecer subsídios para a pesquisa acadêmica.

Os instrumentos de avaliação foram utilizados pelo professor para compor a média do bimestre no ano letivo, atendendo aos requisitos da legislação para o ensino médio. Pretendíamos que o tipo de avaliação proposta, o modo de correção e aferição de notas estivessem coerentes com a metodologia presente no desenvolvimento da seqüência didática. Desse modo, a avaliação considerou as questões respondidas em grupo ou individualmente durante as aulas, a participação dos alunos no debate e no festival cultural, e uma avaliação escrita com consulta ao final da seqüência de aulas, inspirada na proposta da prova operatória de Ronca e Terzi (1993).

Com relação aos interesses desta pesquisa, os questionários, a participação nas atividades e a avaliação final com consulta forneceram dados para a triangulação com os dados obtidos nas gravações em vídeo e as anotações de campo.

\subsection{O apoio ao professor na aplicação do curso}

O curso piloto foi aplicado por uma professora que participava de um projeto no Laboratório de Pesquisa em Ensino de Física (Lapef - FEUSP), financiado pela Fapesp (nº 2003/00146-3), sob a coordenação do prof. Dr. Maurício Pietrocola. Tal projeto previa a dedicação de 20 horas semanais pelos professores da rede pública, além de sua carga horária nas escolas. Nesse tempo estão incluídos o desenvolvimento das atividades em sala de aula (que fornecem os dados para as pesquisas acadêmicas realizadas pelo Lapef), as reuniões semanais com os pesquisadores e o tempo para estudo das atividades.

A professora não tinha formação em história e filosofia da ciência nem havia estudado o assunto, portanto, optamos por oferecer-lhe apoio na aplicação do curso, além de fornecer todo o material necessário. Ela recebeu o planejamento do curso (Apêndice C), os artigos mencionados na bibliografia necessária e complementar (seção 3.3.1), o texto que desenvolvemos para o professor, que apresenta o conteúdo histórico de toda a seqüência de aulas (Apêndice A), os textos para os alunos (Apêndice C), além do material necessário a todas as atividades propostas. 


\subsubsection{Bibliografia fornecida ao professor}

\section{Episódio I}

FORATO, Thaís C. de M. Um pouco sobre a luz na Antiguidade grega. Texto não publicado, desenvolvido para o curso (Apêndice A).

MARTINS, Roberto de A. O universo: teorias sobre sua origem e evolução. São Paulo: Moderna, 1994. Capítulos 1 a 3. Disponível em: <http://www.ifi.unicamp.br/ ghtc/Universo/>. Acesso em: 2 fev. 2007.

Bibliografia básica para todo o curso

MARTINS, Roberto de A. A Torre de Babel científica. Scientific American - Os Grandes Erros da Ciência, Especial História, v. 6, p. 6-13, 2006.

Do éter ao vácuo e de volta ao éter. Scientific American - Os Grandes Erros da Ciência, Especial História, v. 6, p. 92-98, 2006.

\section{Episódio II}

FORATO, Thaís C. de M. A natureza da luz para alguns pensadores do século XVII. Texto não publicado, desenvolvido para a seqüência didática (Apêndice A).

SILVA, Cibelle C.; MARTINS, Roberto de A. A teoria das cores de Newton: um exemplo do uso da história da ciência em sala de aula. Ciência \& Educação, v. 9, n. 1, p. 53-65, 2003.

\section{Bibliografia complementar}

MOURA, Breno A.; SILVA, Cibelle C.. A teoria dos estados da luz: considerações sobre alguns papéis das hipóteses na óptica newtoniana. In: MARTINS, Roberto A.; SILVA, Cibelle C.; FERREIRA, Juliana M.H. e MARTINS, Lilian A.C.P. (Org.). Filosofia e história da ciência no Cone Sul. Seleção de trabalhos do $5^{\circ}$ Encontro. Campinas: Associação de Filosofia e História da Ciência do Cone Sul (AFHIC), 2008, p. 91-100.

SILVA, F. W. O. A evolução da teoria ondulatória da luz e os livros didáticos. Revista Brasileira de Ensino de Física, v. 29, n. 1, p. 149-159, 2007. 


\section{Episódio III}

FORATO, Thaís C. de M. As teorias da luz e o éter luminífero no início do século XIX. Texto não publicado, desenvolvido para a seqüiência didática (Apêndice A).

PIETROCOLA, M. Fresnel e o arrastamento parcial do éter: a influência do movimento da Terra sobre a propagação da luz. Caderno Catarinense de Ensino de Física, v. 10, n. 2, p. $157-172,1993$.

O espaço pleno e a concepção do éter. A Física na Escola, v. 3, n. 2, p. 7-8, out. 2002.

\section{Bibliografia complementar}

MARTINS, R. de A. Em busca do nada: considerações sobre os argumentos a favor e contra o vácuo. Trans/Form/Ação, n. 16, p. 7-27, 1993.

O retorno do éter. Scientific American Brasil, v. 2, p. 27, jul. 2002.

PIETROCOLA, M. O éter luminoso como espaço absoluto. Cadernos de História e Filosofia da Ciência, [série 3], v. 3, n. 1/2, p. 163-182, 1993.

Para a bibliografia de apoio ao professor, buscou-se, sempre que possível, utilizar artigos sobre história da óptica em português, publicados em periódicos nacionais, garantindo a autonomia do professor e favorecendo o acesso a todos que utilizarão futuramente a sequiência didática. $\mathrm{O}$ texto elaborado para o professor (Apêndice A) procurou dar suporte à articulação das idéias condutoras do curso, pois não localizamos publicações em português que atendessem a este objetivo: a articulação das teorias sobre a natureza da luz com o éter luminífero para discutir sobre a natureza da ciência no ambiente escolar.

Pudemos constatar ao longo das reuniões que tivemos com a professora que ela leu todos os textos da bibliografia básica e sugerida. Ela nunca havia trabalhado com história da ciência e estava habituada com cursos mais tradicionais, tanto na seleção de conteúdos voltados à resolução de problemas como com relação às estratégias didático-pedagógicas. Portanto, para ela, o curso foi totalmente inovador quanto ao assunto tratado e à metodologia de trabalho. Ela mostrou-se confiante e motivada com as mudanças e demonstrou empenho, envolvimento e satisfação na condução do curso. 


\subsubsection{As reuniões com a professora e o desenvolvimento do curso}

Foram realizadas quatorze reuniões semanais com a professora antes do início do curso, entre 14 de maio de 2007 e $1^{\circ}$ de setembro de 2007 . Nessas reuniões discutíamos os textos da bibliografia, as apresentações em slides e os recursos materiais para todas as atividades, além de esclarecer as dúvidas que surgiam sobre os textos para os alunos. A ênfase foi dada ao material e nosso apoio foi mais intenso no sentido de esclarecer algumas dúvidas que surgiam com relação à parte histórico-epistemológica.

Grande parte do texto para o professor já estava pronta quando apresentamos a proposta ao professor. Entretanto, foram realizadas alterações em função das características da escola e dos alunos. A síntese das reuniões de trabalho com a professora, apresentada a seguir, permite-nos acompanhar o cronograma de desenvolvimento de algumas partes do curso:

14/5/07 - Apresentamos o projeto do curso piloto para a professora, a primeira versão do planejamento e os conteúdos pretendidos. Esclarecemos que o objetivo do curso seria usar a história da ciência para discutir a natureza da ciência.

21/5/07 - Esclarecemos como os conteúdos em história da ciência estavam sendo selecionados, quais fontes primárias e secundárias estavávamos utilizando. Apresentamos os aspectos da natureza da ciência possíveis de ser discutidos por meio da história da ciência, segundo Pumfrey (1991). Discutimos a possibilidade de realizar o teatro. A primeira versão pensada naquele momento envolvia apenas o debate entre Fresnel e a banca do concurso (veja textos do episódio III). Apresentamos a proposta da linha do tempo, que agradou à professora. Ela comprometeu-se a tomar as medidas da sala de aula para definirmos o tamanho da faixa. Conversamos sobre alguns filmes e como eles poderiam ser usados para localizar o aluno na dimensão temporal, tendo uma noção da cronologia dos eventos a serem tratados no curso. Discutimos a possibilidade de trabalhar os filmes e a linha do tempo com outros professores: biologia; filosofia; história e literatura. Percebemos a necessidade de fornecer aos alunos alguns roteiros para observação do filme, no caso de serem utilizados por outras disciplinas, pois em nossa seqüência não haveria tempo para tais atividades. Tal interação multidisciplinar acabou não ocorrendo, pois não houve tempo disponível para preparar essas orientações ou planejar ações conjuntas com outras disciplinas. Fica como sugestão para outras aplicações do curso. 
28/5/07 - A professora comentou que os alunos gostaram da idéia do teatro e já havia candidatos interessados em encenar a peça. Ela nos forneceu a medida da parede para a construção da linha do tempo: 6,0 m. Lemos juntas a introdução do texto histórico preparado para o professor e falamos sobre o debate Fresnel versus corpuscularistas.

4/6/07 - Apresentamos para a professora o primeiro esboço dos slides para o primeiro episódio. Iniciamos juntas a leitura dos três primeiros capítulos do livro $O$ Universo (MARTINS, 1994), para ajudar no embasamento teórico da primeira aula. A professora ficou de ler o restante em casa para discutirmos na reunião seguinte.

11/6/07 - Comentamos sobre qual poderia ser uma lista mínima de filmes históricos acerca dos episódios que seriam tratados no curso e selecionamos alguns ela iria sugerir para os alunos assistirem nas férias. Comentamos sobre os capítulos 1 a 3 de Martins (1994). A professora leu o texto para o professor do episódio I, e discutimos suas dúvidas sobre o texto.

18/6/07 - Relemos o texto para o professor acerca do episódio I com algumas modificações e fizemos a leitura do episódio II.

25/6/07 - Discutimos o artigo da Scientific American (MARTINS, 2006a): “A torre de babel científica", que enfatiza aspectos da natureza da ciência que seriam trabalhados no nosso curso.

30/7/07 - Apresentamos para a professora o planejamento que estava sendo desenvolvido para o curso e o texto definitivo para o teatro.

6/8/07 - Discutimos sobre a data para o teatro e o momento do curso que seria mais adequado para ocorrer. Falamos sobre a primeira atividade da linha do tempo e lemos os textos recomendados para o episódio III. Entreguamos para a professora o restante dos textos previstos na bibliografia para ela realizar a leitura em casa.

13/8/07 - Realizamos a primeira atividade que seria desenvolvida com os alunos. Apresentamos para a professora a faixa contendo linha do tempo e a esclarecemos sobre os pontos pretendidos para a aula. Discutimos a biografia de Newton que os alunos utilizariam na introdução do episódio II. Lemos e discutimos o texto "O éter como espaço absoluto" (PIETROCOLA, 1993). Rediscutimos o momento do teatro no curso e os possíveis problemas decorrentes de apenas um grupo de alunos terem acesso ao texto antes do início das aulas. Pretendíamos que o teatro fosse usado como estratégia pedagógica para motivar 
o aluno com o tema do episódio III. Foi o risco necessário a assumir em função do contexto da escola.

15/8/07 - Reunião "extra" na escola com a professora e com os alunos: foi a ocasião de conhecer os alunos, o ambiente no qual o curso seria apresentado e verificamos as instalações para os equipamentos da gravação. Entregamos para a professora os quatro primeiros textos escritos para os alunos.

Nesse primeiro contato com todos os alunos da sala, a professora e a pesquisadora falaram sobre o curso e foi esclarecido como seria realizada a coleta de dados. Fizemos depois a primeira reunião com o grupo de teatro. Lemos o roteiro para a peça juntos e falamos sobre a criação do cenário, figurino e abertura do teatro. Os alunos mostraram-se bastante motivados com a atividade e aceitaram que seria preciso, naquele momento, decorar as falas mesmo sem entender os conceitos e teorias tratadas. A previsão para a apresentação era dia 14/9, portanto eles tinham cerca de um mês para os ensaios e a criação dos complementos necessários.

20/8/07 - Discutimos as dúvidas da professora a respeito dos textos 1 a 4 escritos para os alunos.

27/8/2007 - Lemos os textos para o debate (textos 5 e 6) e discutimos os planos para desenvolver a atividade.

1\%9/07 - Realizamos a segunda reunião com os alunos voluntários para o ensaio da peça teatral (sábado). Depois do ensaio, foi feita outra reunião extra com a professora. Apresentamos para ela os slides desenvolvidos para o episódio II e lhe entregamos a versão definitiva dos textos 7 e 9 para o curso piloto.

6/9/07 - Início do curso.

10/9/07 - Encontro "extra" com a professora: apresentamos para ela os slides desenvolvidos para o episódio III.

17/9/07 - Início da correção das questões do episódio I junto com a professora.

20/9/07 - Último dia de curso. Depois da aula, comentamos as impressões gerais e ficou claro que a professora estava satisfeita e havia considerado o curso um sucesso.

Entre 6/9 e 20/9, nós nos encontrávamos todos os dias na aula e depois comentávamos rapidamente $\mathrm{o}$ andamento do curso, questões a reforçar, pontos a 
problematizar. Por exemplo, percebemos que durante o episódio II alguns alunos mantinham a visão de "provas" das teorias científicas. A questão foi retomada durante a sistematização do episódio II e ouvimos uma aluna comentando que "agora" havia entendido. Nas reuniões semanais que se seguiram ao curso corrigimos as atividades produzidas pelos alunos e a avaliação final.

\subsubsection{Tempo exigido do professor na aplicação do curso piloto}

Uma das preocupações que a aplicação do curso piloto suscitou foi com relação ao tempo requerido para a preparação da professora. Tal preocupação não se refere a esse curso piloto especificamente, pois a professora recebia uma bolsa do Estado que permitia sua dedicação ao projeto, mas, sim, com outros professores em distintos contextos de aplicação. Não pretendemos inviabilizar a utilização da história e filosofia da ciência no ensino, sugerindo uma demanda mínima de tempo de preparação que não condiz com a realidade dos professores das escolas públicas brasileiras. A grande quantidade de aulas que os professores assumem e a escassez de tempo para uma formação continuada, por exemplo, é a realidade que vem sendo apontada por inúmeras pesquisas educacionais (RoDRIGUES, 2001). Desse modo, é necessário dimensionar o tempo requerido por esse caso específico e buscar realizar uma estimativa da demanda temporal necessária em outros contextos educacionais.

A professora desse curso compareceu a quatorze reuniões que duravam de duas a três horas, e parte desse tempo era utilizada para a leitura dos textos. Além disso, ela utilizava mais duas horas semanais em média para terminar a leitura em casa, e quando necessário, uma hora na preparação das aulas, no estudo dos slides ou outras atividades. Em nosso caso específico, estimamos que ela tenha utilizado em torno de cinco horas semanais. Entretanto, é preciso relembrar que nesse tempo foram desenvolvidas diferentes atividades:

1. Leitura de todos os textos dos alunos.

2. Leitura de ao menos duas versões do texto para o professor.

3. Leitura de todos os textos da bibliografia básica.

4. Leitura de todos os textos da bibliografia complementar.

5. Discussões com a pesquisadora sobre as eventuais dúvidas surgidas. 
6. Assistir a apresentação dos slides que deveria apresentar aos alunos, realizada pela pesquisadora.

7. Apresentar os slides à pesquisadora.

8. Discutir a viabilidade das atividades didáticas propostas para o curso e recursos estruturais necessários para realizá-las.

A leitura dos textos escritos para os alunos que seriam trabalhados em sala e a preparação de recursos pedagógicos podem ser consideradas como atividades mínimas que todo professor realiza, ou deveria realizar, para preparar sua aula, qualquer que seja o seu tema. Essa atuação na transposição didática interna ocorre como parte das funções do professor no exercício de sua docência (Chevallard, 1991). Portanto, o tempo dedicado a tais atividades será apenas um pouco maior do que ele dedicaria a conteúdos da ciência.

Os textos para os alunos do curso piloto têm em média três páginas, incluindo algumas imagens, e exigiram do professor poucos minutos de leitura semanal. A preparação das atividades também não demandou muito tempo, pois foram descritas no planejamento que acompanha o curso, de modo que o professor só necessitou adequá-las ao seu contexto de trabalho, quando necessário.

Um fator que deve ser lembrado é a formação anterior em história e filosofia da ciência que o professor tenha recebido ou não. Tomemos o caso de um professor que nunca tenha estudado ou trabalhado com o tema, que é o caso da professora em questão. Acreditamos ser indispensável a leitura de todos os textos da bibliografia básica e, dependendo de suas características pessoais e da sua compreensão do conteúdo, é necessário, também, ler os textos da bibliografia complementar.

Assim, para a aplicação desse curso, o tempo extra exigido foi o dedicado à leitura da bibliografia recomendada ao professor: a básica e a complementar.

Os dois textos que compõem a bibliografia básica para todo o curso devem ser lidos antes dos demais, e podem requerer até duas horas de leitura, dependendo da facilidade ou dificuldade que o leitor tenha desse tema.

No episódio I, há dois textos de bibliografia básica que requerem de uma a duas horas de leitura e fundamentam as 5 horas-aulas previstas.

No episódio II, são necessários dois textos básicos, que possivelmente demandam cerca de duas horas de estudo. Os outros dois textos da bibliografia complementar podem 
requerer também até duas horas de leitura. Essas quatro horas fundamentam seis horas-aula do curso.

Para o episódio III, são necessários três textos básicos, que podem requerer até duas horas em sua leitura. Os três textos da bibliografia complementar provavelmente demandam cerca de duas horas de leitura. Tais textos fundamentam mais seis horas-aula do curso.

As demais quatro horas-aula do curso são voltadas à avaliação final e ao festival cultural e não requerem mais leituras.

Sintetizando as reflexões efetuadas acima, podemos estimar que um professor que não tenha estudado anteriormente o conteúdo do curso poderá necessitar de no mínimo cerca de nove horas de estudo, além daquelas normalmente dedicadas à preparação de aulas, para aplicar esse curso previsto para durar vinte horas-aula. Esse período é em geral quase a totalidade da carga horária destinada à física em um bimestre do ano letivo.

Para um professor que não tenha conhecimento algum do tema e não sentir segurança em aplicar o curso lendo apenas a bibliografia básica, poderá requerer cerca de quatro horas para a bibliografia complementar.

Quadro 2: Estimativa do tempo de leitura requerido do professor (em horas)

\begin{tabular}{|l|c|c|}
\hline & Bibliografia básica & $\begin{array}{c}\text { Bibliografia } \\
\text { complementar }\end{array}$ \\
\hline Introdução & 2 & - \\
\hline Episódio I & 2 & - \\
\hline Episódio II & 2 & 2 \\
\hline Episódio III & 3 & 2 \\
\hline Total & 9 & 4 \\
\hline
\end{tabular}

Naturalmente essa é apenas uma estimativa, pois o tempo de compreensão dos textos varia de acordo com características pessoais, tanto sendo menor como maior que o previsto. Nossa preocupação é ter uma idéia do investimento necessário em distintos contextos de aplicação.

Tomemos agora o caso de um professor que tenha estudado alguns tópicos da história da ciência em sua formação em disciplinas que apresentam uma visão panorâmica da evolução de alguns conceitos da física. Tais disciplinas costumam apresentar uma narrativa (veja capítulo 1, seção 1.2.3) de alguns fatos científicos considerados relevantes 
para a compreensão da construção da ciência aceita atualmente. Conforme discutimos no capítulo 1, não nos parece haver problema em tais narrativas, desde que fique claro para o aluno tratar-se de uma seleção de fatos históricos eleitos mediante um objetivo específico e que a construção da ciência não se resume a isso.

Embora as teorias de Newton e Huygens sobre a natureza da luz possam ser tema corriqueiro em tais cursos, é pouco provável que sejam abordadas destacando os aspectos específicos da natureza da ciência selecionados para esse curso. Possivelmente, a leitura da bibliografia básica seja suficiente para o professor tratar do episódio II do curso piloto.

Uma situação parecida pode ocorrer com Thomas Young e a teoria ondulatória, e parece-nos pouco provável, também, que diversos aspectos enfatizados no curso com relação ao éter luminífero e os da natureza da ciência sejam normalmente tratados. Ainda assim, é indispensável a leitura da bibliografia básica, e a bibliografia complementar será necessária dependendo da facilidade que o professor tenha na compreensão do tema, tendo lido apenas os textos básicos, além, é claro, daqueles voltados aos estudantes.

Podemos imaginar uma variedade de situações, contudo, acreditamos que a ampla maioria esteja contemplada na estimativa de dez horas como o máximo tempo requerido para as leituras voltadas ao professor, em uma primeira vez que aplicaria esse curso.

Descrevemos neste capítulo os caminhos metodológicos desta pesquisa. Apresentamos nosso problema de pesquisa e a metodologia de análise qualitativa adequada a ela, e os condicionantes da tomada de dados. Descrevemos a construção do curso piloto, $\mathrm{o}$ apoio e o acompanhamento dado à professora. No próximo capítulo faremos a análise dos dados oriundos da parte empírica, tanto os desafios vivenciados na elaboração do curso, e as propostas para superá-los, como os dados advindos da aplicação do curso em ambiente escolar. 


\section{Análise dos dados e resultados}

"Se você me falar, provavelmente vou esquecer; se você me mostrar, vou me lembrar; mas, se você me envolver, eu vou entender"

Confúcio

Neste capítulo apresentaremos a análise dos dados provenientes da parte empírica da pesquisa: a elaboração do curso piloto e sua aplicação em ambiente escolar.

Inicialmente, discutiremos os dados oriundos da elaboração do curso piloto, mais especificamente, os desafios vivenciados durante essa etapa e as soluções propostas para seu enfrentamento. Os dados são predominantemente descritivos e têm o pesquisador como seu agente de coleta (ERICSON, 1998). Tais relatos descrevem as dificuldades encontradas na relação interpessoal do sujeito-pesquisador com o saber na construção do Saber a Ensinar. Buscamos registrar da maneira mais fidedigna possível as dúvidas, as conjecturas feitas sobre os caminhos possíveis e as dificuldades em fazer escolhas.

Em seguida, apresentaremos a análise de três eventos específicos que permitem responder a algumas das questões da pesquisa (seções 1.2.1 e 3.1.1) e, ao mesmo tempo, fornecem uma amostra das possibilidades de abordagem que os dados permitem.

Faremos ainda uma breve descrição de dois pontos interessantes da parte empírica da pesquisa, mas que não se caracterizaram, nesse momento, como os eventos mais significativos a serem enfocados. Pretendemos analisá-los como um dos desdobramentos desta pesquisa.

Finalmente, discutiremos alguns resultados oriundos do contato com os dados.

\subsection{Desafios vivenciados durante a elaboração do curso}

Os requisitos da didática das ciências e as prescrições da dimensão teórica dos campos histórico e epistemológico apontam diferentes tipos de desafios na transposição didática desses conhecimentos para a educação científica (seções 1.2.3 e 2.3). Na criação do curso piloto, que descrevemos no capítulo anterior, buscamos harmonizar as exigências dos dois campos de conhecimento, prescritas pela dimensão teórica. Isso possibilitou materializar os desafios previstos pelo quadro teórico de modo mais detalhado e fundamentá-los por meio de exemplos concretos. Esses desafios manifestaram-se tanto na 
seleção e transformação do Saber Sábio em Saber a Ensinar e, em particular, nos processos de descontextualização, despersonalização, dessincretização e na posterior recontextualização para o ambiente escolar, no nível de escolaridade enfocado (Chevallard, 1991).

Organizamos os desafios em termos de obstáculos estruturais, pois eles se vinculam à própria essência do processo de didatização, que envolve a negociação entre os domínios epistemológicos, as exigências do projeto educacional e as possibilidades do campo de aplicação didática (a sala de aula). Além disso, tais obstáculos estruturais poderiam ser, numa primeira análise, avaliados como superáveis ou contornáveis em função dos contornos da negociação em jogo, isto é, das escolhas feitas mediante seu enfrentamento na elaboração do Saber a Ensinar.

Consideramos como obstáculos estruturais superáveis aqueles desafios que envolviam um conjunto de dificuldades para as quais julgamos possível obter uma solução ampla. Ou seja, neste caso, o Saber a Ensinar produzido incorpora ações ou estratégias que contribuem para a superação dos desafios considerados.

Os obstáculos estruturais contornáveis vinculam-se a desafios que envolvem um conjunto de dificuldades para os quais julgamos não ser possível uma solução ampla. Ou seja, nestes casos, ou se resolvem integralmente algumas das demandas da negociação em jogo, ou se atende parcialmente a todas elas. Isso pode ocorrer em função das especificidades do Saber Sábio, de limites do professor ou dos alunos, ou de condições disponíveis no sistema de ensino. A análise tornará mais claro que essas dificuldades envolviam elementos que extrapolavam os limites e possibilidades do curso em questão. $\mathrm{O}$ enfrentamento desses desafios requereu assumir riscos, fazer escolhas, adotar estratégias visando a contornar alguns obstáculos sobre os quais não poderíamos atuar, como a inevitável falta de formação do professor e a limitação do tempo, por exemplo.

Alguns desses desafios colocavam em conflito certas exigências teóricas dos campos didático, historiográfico e epistemológico, como extensão e profundidade do conhecimento, ou ainda de aprendizagem, como o domínio da leitura ou da matemática. Tais conflitos se configuravam como dilemas, pois requeriam decidir privilegiar um aspecto em detrimento do outro. Em geral, era necessário optar ou pelas prescrições historiográficas, correndo o risco de se afastar demais de um enfoque acessível ao aluno, ou omitir aspectos da história da ciência, assumindo o risco de incorrer em excessiva 
simplificação. Em certos momentos, foi necessário escolher para qual dos dois lados a balança penderia mais. Tais escolhas foram feitas pontualmente em função dos objetivos visados em cada aspecto específico e mediante a avaliação de possíveis consequências.

Os graus de dificuldade para o enfrentamento desses desafios variou bastante. Conforme será discutido nas próximas seções, alguns obstáculos exigiram mais reflexão, empenho e assunção de riscos do que outros. Há alguns casos nos quais os desafios não eram exatamente dificuldades e sim, etapas que mereceram atenção e ponderação diferenciada. Há outros casos nos quais os desafios geravam conflitos ou mesmo dilemas como, por exemplo, optar por excluir ou não a matematização dos fenômenos ópticos tratados. De qualquer modo, tanto buscar superar como contornar os obstáculos envolveram fazer escolhas e assumir riscos.

Alguns dos desafios que discutiremos apresentam aspectos em comum, mas decidimos pontuar separadamente cada tipo de obstáculo enfrentado, buscando realizar a descrição mais fidedigna possível das dificuldades, incertezas e conflitos que vivenciamos na elaboração do curso.

As propostas e ações adotadas para lidar com os obstáculos, e que serão descritas abaixo, estão detalhadas no planejamento pedagógico (Apêndice C.1), na descrição da construção do curso piloto (seção 3.2), e nos textos para os alunos (Apêndice C.2) e para o professor (Apêndice A).

Buscando organizar os dados, estabelecemos o código "OS” para os obstáculos superáveis e, "OC” para os obstáculos contornáveis. Apresentaremos a relação desses obstáculos e, em seguida, explicaremos cada um deles.

\subsubsection{Obstáculos superáveis: construindo propostas}

OS1. Concepção de ciência a ser apresentada: seleção dos aspectos da natureza da ciência.

OS2. Seleção dos aspectos históricos a enfatizar em cada episódio.

OS3. Nível de aprofundamento de alguns aspectos históricos.

OS4. Nível de detalhamento do contexto não científico.

OS5. Nível de aprofundamento de alguns aspectos epistemológicos. 
OS6. Se, quando, quanto e como utilizar trechos de fontes primárias para o professor e para o aluno.

OS7. Formulação discursiva adequada ao nível de escolaridade visado.

OS8. Tratar, diacronicamente, diferentes concepções de ciência e pensadores de distintas épocas e conteúdos da história da ciência de difícil compreensão na atualidade.

OS9. Construção de atividades de ensino adequadas sob o ponto de vista pedagógico.

Consideramos que esses obstáculos estruturais são tipos de desafios passíveis de serem superados por meio de ações ou estratégias planejadas, e foram enfrentados fazendose escolhas e assumindo-se riscos. Faremos a seguir a descrição de cada um deles.

OS1. Concepção de ciência a ser apresentada: seleção dos aspectos da natureza da ciência

Quando se opta pelo uso da história da ciência na educação científica, com a finalidade de discutir aspectos da natureza da ciência, é necessário escolher qual concepção de ciência pretende-se adotar, e quais aspectos dessa concepção serão trabalhados (seção 1.2.4). Atualmente, há certo consenso entre educadores de várias partes do mundo sobre uma concepção desejável de natureza da ciência para a formação do aluno, e ela vem sintetizada na literatura educacional (GIL PEREZ et al., 2001; LEDERMAN, 2007; MCCOMAS et al., 1998). Para selecionar os aspectos que iríamos abordar, levamos em conta vários fatores.

O primeiro deles foi o estabelecimento do propósito pedagógico que pretendíamos com o curso (seção 1.2.4). Depois disso, consideramos o tempo didático disponível, além dos pré-requisitos que os alunos possuíam, para determinar qual nível de aprofundamento seria possível e quais aspectos poderiam ser compreendidos por eles. Cada mensagem que se quer passar sobre a natureza da ciência requer algumas estratégias pedagógicas específicas, para que possa ser apreendida pelos alunos. Apenas apresentar informações, sem permitir aos alunos vivenciarem algum tipo de interação com o saber, não favorece um aprendizado significativo.

Esse primeiro desafio não é exatamente uma dificuldade, mas um primeiro passo necessário na elaboração de uma proposta de curso a ser implementado, e requer critérios e 
reflexões. Buscando chamar a atenção para a sua importância, foram incluídos nos obstáculos estruturais superáveis, pois acreditamos que é possível lidar com os fatores envolvidos e elaborar uma proposta adequada.

\section{OS2. Seleção dos aspectos históricos a enfatizar em cada episódio}

Depois que estabelecemos o tema e os três episódios históricos do curso piloto, começamos as conjecturas acerca de cada aspecto do conteúdo que deveríamos abordar (seções 3.2.3 e 3.2.4). Por exemplo, No episódio I, que tratava das explicações dos filósofos gregos para a luz, por exemplo, tínhamos a possibilidade de tratar diversas teorias, como as explicações para a luz de Pitágoras, Leucipo, Empédocles, Platão, Aristóteles e Euclides. Nossas dúvidas iniciaram-se ao refletirmos sobre quais critérios deveríamos utilizar para decidir quantas teorias seriam suficientes para atingirmos o objetivo proposto, e quais dessas teorias poderiam trazer maiores contribuições para alcançá-lo. O primeiro critério foi considerar os propósitos do curso como um todo e os propósitos do episódio histórico em questão (seções 3.2 e 3.3). Como em nenhum momento pretendíamos fazer uma abordagem matemática ou geométrica da luz, a contribuição de Euclides foi a primeira a ser excluída. Em seguida, ocorreu-nos, como critério apropriado, abordar três teorias consideravelmente distintas, vinculadas às respectivas concepções de mundo de seus autores e, possivelmente, de fácil compreensão por parte dos alunos.

A escola atomista, por exemplo, além de abordar conceitos não raros no ambiente escolar, inclusive nas aulas de química, apresentou-se como uma opção interessante. Entre os atomistas, Leucipo trazia uma abordagem que nos pareceu mais passível de simplificação. Sua explicação para a luz envolvia algo que emanava dos corpos e chegava aos olhos. A explicação de Empédocles era um ótimo contraponto à escola atomista, já que se baseava no fogo visual que saía dos olhos. Com as duas teorias, tínhamos duas explicações bem distintas, que acabaram apontando para a terceira possibilidade: a explicação de Aristóteles, que destacava a importância e o papel do meio material entre o observador e o objeto, para explicar a natureza da luz e a visão. Levando em conta o tempo disponível para o episódio e seus propósitos pedagógicos, achamos desnecessário incluir mais informações. 
Refletindo sobre as escolhas e conteúdos selecionados e/ou excluídos dos outros episódios - por exemplo, a omissão da óptica de Alhazen dos instrumentos ópticos no século XVII e da matematização das teorias no XIX, percebemos alguns indicativos dos critérios que utilizamos na elaboração da proposta de superação desse obstáculo da seleção dos conteúdos: (i) os propósitos do curso como um todo e os propósitos de cada episódio; (ii) um conteúdo que tenha algum vínculo com as necessidades dos próximos episódios, contudo, sem reduzi-lo a fins meramente propedêuticos; (iii) maior viabilidade de simplificação sem incorrer em pseudo-história e (iv) os pré-requisitos que os alunos necessitam possuir para compreender os conceitos envolvidos.

É importante relembrar que, quando se estabelece um conteúdo de Saber a Ensinar, é necessário levar em conta o projeto político-pedagógico da escola, por sua vez, inserido em um determinado contexto educacional. Não se deve esquecer que a seleção do Saber a Ensinar envolve várias instâncias da noosfera (CHEVALLARD, 1991). Embora tal conjectura não tenha interferido em nossas decisões para a seleção do tema a ser tratado, em função do contexto de aplicação explicitado anteriormente, ele deve ser levado em conta em outras pesquisas e/ou outras propostas de curso.

\section{OS3. Nível de aprofundamento de alguns aspectos históricos}

Depois de selecionados os conteúdos de cada episódio, foi necessário estabelecer o nível de aprofundamento a ser dado a cada um deles. As eidola da escola atomista, por exemplo, seriam tratadas como partículas, como películas ou como filmes? Optamos por adotar uma simplificação, tratando-as como corpúsculos, pois essa noção não traria problemas de natureza historiográfica nem entraria em conflito com os objetivos do episódio. No episódio II, que enfocou o século XVII, avaliamos os riscos e os benefícios de apresentar a teoria de Huygens como uma teoria de tipo ondulatória e não como uma teoria vibracional. Tendo em vista o nível de escolaridade enfocado, os propósitos do curso e os propósitos dessa teoria no episódio (seções 3.2.3 e 3.2.4), entendemos que tal simplificação não pode ser considerada como uma distorção histórica. Desconsiderar a diferença entre ambas não seria adequado em um trabalho voltado à comunidade da história da ciência. Entretanto, essa discussão não se mostrou relevante para o enfoque escolhido, no contexto de elaboração e aplicação do curso piloto. Nesse caso, os saberes voltados ao especialista e os saberes voltados ao estudante do ensino médio, possuem funções sociais distintas (seção 2.2). 
As mesmas conjecturas valeram para a abordagem da teoria da natureza da luz de Newton. Enquanto um trabalho especializado em história da ciência, mereceria uma discussão das diferentes concepções de luz que aparecem na obra de Newton, ora apresentada como corpúsculos e ora como raios de luz, essa diferença não era significativa para o enfoque escolhido, pelo contrário, traria um nível de detalhamento inadequado ao ensino médio e aos propósitos do curso. A descrição do experimento com o prisma deveria ser muito mais detalhada, se o curso piloto fosse voltado à formação inicial de professores, mas no caso do nível de escolaridade enfocado pelo curso, optamos por uma simplificação.

Tendo em vista nossas reflexões, e outras conjecturas feitas em detalhes de cada conteúdo, podemos perceber que não são apenas prescrições historiográficas e didáticas que interferem no nível de aprofundamento dos conteúdos históricos. Definir esse nível depende também do contexto de aplicação e dos objetivos almejados com cada aspecto abordado. Um detalhe que pôde ser simplificado ou omitido no curso piloto, pode fazer toda diferença em outro contexto de aplicação ou mediante outros objetivos pedagógicos.

\section{OS4. Nível de detalhamento do contexto não científico}

Um dos aspectos da natureza da ciência que desejávamos discutir no curso era: "a ciência é uma atividade humana influenciada pelo contexto sociocultural de cada época". Isso requeria apresentar exemplos históricos de fatores extra-científicos que teriam influenciado os conteúdos da ciência tratados pelo curso. Dois conteúdos do tema pareceram-nos adequados para chamar a atenção para isso: o prestígio de Newton contribuindo para a aceitação da teoria corpuscular e o apoio de Arago para que Fresnel desenvolvesse sua teoria. Havia, entretanto, a preocupação de não sobrevalorizá-los, sugerindo posições extremas.

Consideramos "definir nível de detalhamento do contexto não científico" como um obstáculo superável, pois parece-nos possível refletir e planejar a abordagem que permita mostrar a influência do contexto na construção da ciência, sem desvalorizar os outros aspectos. Com Newton,, por exemplo, enfatizamos sua extrema dedicação na realização de inúmeros experimentos e na abordagem matemática. No caso de Fresnel, buscamos ressaltar o apoio material de Arago para a realização de seus estudos, mas salientar a importância da matemática na elaboração de sua teoria. 
OS5. Nível de aprofundamento de alguns aspectos epistemológicos

Durante a elaboração do Saber a Ensinar, percebemos que a abordagem dos aspectos da natureza da ciência que queríamos discutir requeria a utilização de alguns conceitos epistemológicos. Seria necessário utilizar idéias como a formulação de hipóteses e a elaboração de teorias, por exemplo, ou ainda a concepção de evidências experimentais ou argumentos racionais. Nosso pressuposto, que os alunos nunca haviam estudado tais conteúdos, foi confirmado durante as reuniões com a professora. Nesse momento deparamo-nos com a necessidade de optar por apresentar esses conceitos aos alunos ou assumir que sua compreensão poderia vir da sua própria utilização nas situações estudadas. Decidimos enfrentar esse obstáculo e construir os textos e as atividades de modo a utilizar tais conceitos, sem defini-los formalmente, mas construindo uma narrativa que promovesse a sua compreensão.

OS6. Se, quando, quanto e como utilizar trechos de fontes primárias para o professor e para o aluno

A interpretação de fontes primárias não é um aspecto trivial da metodologia de trabalho do historiador da ciência. Tomemos como exemplo o episódio dos gregos no contexto do trabalho. Compreender Aristóteles falando sobre a luz e seu sistema de mundo, certamente requereu muitos anos de dedicação dos especialistas. Tratar desse tema sem possuir conhecimentos mínimos sobre a obra de Aristóteles em seu contexto, requer o apoio de fontes secundárias e conhecer minimamente aspectos metodológicos e historiográficos da história da ciência.

Na elaboração dos textos do episódio I, que tratava da Antiguidade, foi necessário utilizar o apoio de várias fontes secundárias, na tentativa de minimizar uma compreensão equivocada dos trechos primários consultados (COHEN; DRABKIN, 1958; LINDBERG, 1976, 1992; PARK, 1997; MARTINS, 1996, 2001). Claro que, no processo de descontextualização do Saber Sábio e na sua recontextualização para a criação do Saber a Ensinar, levamos em conta que o resultado voltava-se aos objetivos do curso para o ensino médio e não para a comunidade de historiadores. Se, por um lado, isso minimiza certas exigências pertinentes à academia, por outro os cuidados com a mensagem que cada informação pode sugerir deve ser redobrado.

No primeiro episódio decidimos não utilizar trechos de fonte primária. Receamos que fosse muito difícil não reforçar possíveis concepções prévias e estereotipadas de um 
contexto cultural tão distinto do nosso. Seria necessário investir mais tempo do que dispúnhamos, tentando conduzir a leitura na tentativa de minimizar interpretações anacrônicas.

No episódio II, o século XVII, consideramos que seria mais fácil construir uma narrativa no texto que pudesse auxiliar na leitura dos trechos primários. Muito provavelmente essa decisão deveu-se a uma situação pessoal de maior familiaridade com esse período. ${ }^{16}$ Pareceu-nos ser possível superar esse obstáculo estrutural auxiliando o leitor na interpretação dos trechos primários.

Essas duas situações extremas, apresentadas acima, para esse caso particular (a elaboração do curso piloto), sugerem que a opção pelas fontes primárias deve ser feita mediante alguns requisitos. As circunstâncias contextuais da produção de determinada fonte primária deve ser minimamente conhecida pelo professor que irá utilizá-la em aula ou pelo autor do material didático. Pensamos que estar seguro com relação à interpretação dos aspectos a serem discutidos é um requisito indispensável para o uso das fontes primárias. Além disso, é necessário selecionar um trecho que possa ser inteligível ao aluno, despertar nele algum interesse, e não ser demasiado longo do ponto de vista do nível de escolaridade enfocado.

Por mais interessante e instigadora que possa parecer a apresentação de fontes primárias aos alunos, seria desejável sua leitura ser acompanhada por alguém com um mínimo de conhecimento do período histórico, para conduzir uma interpretação diacrônica. Entretanto, isso provavelmente não ocorrerá na maioria das escolas. Dessa forma, é necessário bom senso para avaliar os riscos e benefícios para decidir quando utilizar trechos de fontes primárias em textos voltados ao estudante. Ainda assim, parece-nos importante que tais trechos venham entremeados por explicações e esclarecimentos para auxiliar sua interpretação.

Desse modo, julgamos que esse obstáculo estrutural pode ser superado, pois, para favorecer a interpretação de extratos de fonte primária, pode-se incluir explicações no material para o aluno e para o professor.

\footnotetext{
${ }^{16}$ O século XVII foi o período enfocado em minha dissertação de mestrado (Forato, 2003) que tratou de alguns aspectos teológicos da obra de Newton.
} 
OS7. Formulação discursiva adequada ao nível de escolaridade visado

Quando se descontextualiza o saber de referência, despersonalizando-o e dessincretizando-o para a criação do Saber a Ensinar, torna-se necessário que o processo de retextualização leve em conta o nível de escolaridade enfocado.

Nossa proposta para superar esse obstáculo estrutural envolveu aspectos formais do texto, de vocabulário e de conteúdo. Decidimos utilizar a norma culta na correção gramatical, mas adotar uma linguagem coloquial e despretensiosa. Havia, é claro, muitos termos e expressões novas para os alunos, mas buscamos, sempre que possível, que o próprio texto permitisse a sua compreensão. Espera-se que o aluno adquira novos vocabulários e amplie seus conhecimentos, quaisquer que sejam os conteúdos trabalhados, mas um texto que permita autonomia na compreensão da maior parte das novas expressões parece-nos que tende a apresentar melhor aceitação entre os mesmos. Tentamos construir um texto de modo que o significado dos novos termos fosse tornando-se mais claro conforme o estudante compreendesse os exemplos históricos.

Com relação ao conteúdo, cada aspecto requereu reflexão sobre o que omitir, o que destacar e como abordar. Essas escolhas foram guiadas pelo papel que cada detalhe desempenharia no propósito do curso piloto. Apresentamos alguns exemplos mais específicos sobre essa questão nos outros desafios discutidos nessa seção.

OS8. Tratar diacronicamente diferentes concepções de ciência e pensadores de distintas épocas, e conteúdos da história da ciência de difícil compreensão na atualidade.

Levar em conta as diferenças entre a concepção de ciência em distintas épocas e nas diferentes ciências foi um obstáculo estrutural que motivou significativamente nossa reflexão. Como o aluno poderia interpretar as diferentes concepções de ciência, tanto entre os três episódios enfocados, quanto em relação à ciência atual? A interpretação anacrônica de que o fracasso das teorias do passado deve-se ao "atraso científico" de cada período é a concepção mais usual referida pela literatura especializada. Como buscávamos problematizar aspectos da natureza da ciência, os estudantes poderiam concluir que as diferentes interpretações para os fenômenos naturais só ocorriam no passado. Foi necessário lidar com as diferenças entre o que os alunos consideram como ciência atualmente e o que era considerado válido para a elaboração de explicações para os fenômenos naturais tratados no período da Antiguidade que enfocamos. A proposta para lidar com esse desafio foi insistir nesse aspecto na preparação da professora. Enfatizamos 
essa preocupação, conversamos sobre possíveis momentos em que tal visão pudesse se manifestar, e como ela poderia posicionar-se diante dessas concepções para promover um entendimento adequado da questão.

Além das diferentes concepções de ciência, há conteúdos da história da ciência que requerem empenho e atenção para serem tratados diacronicamente. Muitos conceitos importantes em diversos momentos da história da ciência podem ser considerados "bizarros" pelos alunos, atualmente. Na elaboração do curso piloto, por exemplo, lidamos com o conceito do éter nos séculos XVII e XIX. Na preparação do material, ponderamos as dificuldades que os alunos teriam para compreender esse ente inobservável. Além dele, outros aspectos conceituais e filosóficos das explicações elaboradas nos três episódios históricos abordados, poderiam ser de difícil entendimento.

Para lidar com esse desafio, inicialmente tentamos selecionar apenas aspectos pontuais das teorias a serem tratadas, que permitissem atingir nossos objetivos. Depois disso, buscamos apresentá-los da maneira mais simplificada possível.

Enfatizamos, na preparação da professora, que o éter e idéias de substâncias e fluidos imponderáveis eram comuns na física dos séculos XVII, XVIII e parte do século XIX. Além disso, destacamos que o éter era utilizado para explicar outros fenômenos naturais e não apenas a natureza da luz.

O desafio de abordar conteúdos da história da ciência, de difícil compreensão na atualidade, configurou-se como um obstáculo superável, pois acreditamos que seria possível propor uma solução para seu enfrentamento. $\mathrm{O}$ caminho que adotamos para lidar com tal desafio foi simplificar a idéia de éter, omitindo aspectos dispensáveis para os objetivos do curso e enfatizando a adequação dessa concepção ao período. É importante o aluno compreender que as concepções de éter e de outros conceitos descartados pela ciência atual eram pertinentes aos seus respectivos períodos, caso contrário, tais conteúdos poderão soar ridículos e nada "científicos". Ou seja, se o aluno não entender que idéias, conceitos e pressupostos da ciência eram pertinentes às práticas consideradas válidas em cada período, ele poderá imaginar que o "atraso do passado" justifica a aceitação de "coisas estranhas". Tal concepção preconceituosa e anacrônica conflita diretamente com o propósito de ensinar uma "ciência se desenvolvendo em um contexto cultural, de relações humanas, dilemas profissionais e necessidades econômicas. Uma ciência parcial e falível, contestável, uma construção cultural" (PUMFREY, 1991). 
Outro desafio enfrentado foi tratar diacronicamente pensadores de épocas e culturas diferentes das nossas. Como auxiliar o aluno a compreender, por exemplo, a concepção de mundo aristotélica ou de Empédocles? Como promover "rapidamente" o entendimento de seus critérios, crenças e valores? Uma vez que o curso é voltado para o ensino da natureza da ciência, não é possível dedicar muito tempo para abordar detalhes históricos do período no nível de profundidade que seria necessário para compreender a visão de mundo em diferentes períodos.

Uma das estratégias que utilizamos para lidar com esse desafio foi a atividade do debate. Quando os alunos assumissem o papel de "cientistas"17 do passado, tendo que justificar suas respectivas teorias utilizando somente os argumentos aceitos naquele período, eles vivenciariam uma dinâmica da defesa de suas idéias e teriam que construir argumentos para defendê-las.

Nesse obstáculo também recorremos à preparação da professora para lidar com idéias que poderiam surgir ao longo das aulas. Nossa preocupação era evitar que os alunos imaginassem que o "atraso dos cientistas do passado" justificaria a sua aceitação de "coisas estranhas". Desse modo, discutimos possíveis interpretações anacrônicas dos alunos e alguns modos para criticá-las.

No momento em que preparávamos o curso piloto, consideramos que seria muito produtivo um trabalho conjunto com outras disciplinas, por exemplo, história e filosofia. Se outros professores da turma conhecessem os textos e os propósitos do curso, poderiam discutir aspectos de suas áreas de especialidade para favorecer ao aluno um entendimento mais amplo do conteúdo. Porém, não seria possível contar com esse recurso naquele momento, e, mais do que isso, não seria apropriado para a pesquisa. Uma vez que pretendemos produzir conhecimento que possa ser replicado, o contexto de aplicação deveria ser o mais autônomo possível. Todavia, julgamos interessante registrar essa

\footnotetext{
${ }^{17}$ No período retratado pelo debate protagonizado pelos alunos, as concepções de ciência, de seus métodos e de seus protagonistas eram diferentes das atuais. Sob o ponto de vista historiográfico, os homens da ciência do século XVII eram filósofos naturais. A partir do século XIX os homens que pesquisavam o mundo natural passaram a ser chamados de cientistas. As diferentes denominações pretendem contextualizar suas práticas a seus respectivos períodos, chamando a atenção para as mudanças na concepção de ciência que ocorreram ao longo da história da ciência.
} 
possibilidade, pois acreditamos que um trabalho multidisciplinar poderia contribuir sobremaneira para a formação dos alunos.

OS9. Construção de atividades de ensino adequadas sob o ponto de vista pedagógico

Um desafio que enfrentamos na elaboração do curso foi "agregar situações fictícias aos episódios históricos" sem criar uma pseudo-história (AllChIN, 2004). Esse desafio manifestou-se na elaboração do roteiro para o teatro. Tínhamos a intenção de desenvolver uma atividade instigadora, envolvente do ponto de vista do aluno. Era necessário tratar aspectos do conteúdo, mas também tornar o curso dinâmico, interessante e desafiador. Pensamos que encenar uma peça teatral poderia atender a esses objetivos. Entretanto, reproduzir um episódio histórico "fidedignamente" em um roteiro de teatro exigiria muito mais tempo, estudo e experiência do que dispúnhamos no momento. Além do mais, nada garantiria que tal versão resultante seria atraente para os estudantes. Decidimos, assim, criar situações fictícias que pudessem enfocar os conteúdos históricos e epistemológicos, mas enfatizando que eram apenas uma invenção. Consideramos, naquele momento, que o importante seria produzir situações que não distorcessem os aspectos da natureza da ciência, ainda que nunca tivessem ocorrido na história da ciência.

\subsubsection{Obstáculos a contornar: em busca de caminhos}

OC1. Concepções ingênuas sobre história e epistemologia da ciência.

OC2. Falta de preparação do professor.

OC3. Inadequação de textos especializados de história da ciência ao ensino médio.

OC4. Falta de pré-requisitos dos alunos em relação ao conhecimento matemático, físico, histórico, epistemológico e filosófico.

OC5. Possível concepção prévia dos estudantes e professores sobrevalorizando a capacidade da ciência atual em resolver todos os problemas.

OC6. Enfatizar aspectos científicos ou enfatizar fatores externos à ciência.

OC7. Quantidade da informação na forma de textos.

OC8. Extensão x profundidade.

Os obstáculos estruturais contornáveis são os desafios cujo enfrentamento exigiu ações e recursos para compensar situações pré-existentes ao curso, como a falta de 
preparação do professor, por exemplo. Essa dificuldade, bem como as outras que serão discutidas abaixo, necessitaram de estratégias para sua compensação, pois não era possível superá-las no nosso contexto de trabalho. Consideramos esses obstáculos como contornáveis, pois sua solução extrapolava os limites do curso piloto. Propusemos estratégias buscando compensar as dificuldades pontualmente, pois não foi possível propor uma solução ampla, conforme discutiremos abaixo.

\section{OC1. Concepções ingênuas sobre história e epistemologia da ciência}

Quando se propõe utilizar a história da ciência na educação científica, mediante as prescrições da historiografia atual, é necessário ter claro que se está apresentando um enfoque diferente da visão que os alunos e demais pessoas da sua convivência possuem (seção 1.2.3). Havíamos adotado como pressuposto que os alunos provavelmente iniciariam o curso piloto com uma visão excessivamente empirista da ciência e com a crença de que os cientistas provam suas teorias. De fato, essas características haviam sido apontadas pela dimensão teórica, pois, ao recomendar o ensino da natureza da ciência, os especialistas buscam, exatamente, modificar tais concepções (LEDERMAN, 2007).

Além disso, a concepção que se busca apresentar aos alunos é diferente daquela trazida pelos materiais didáticos. Isso significa que o curso deve lidar não apenas com concepções presentes fora do ambiente escolar, mas que a visão apresentada pelo professor irá conflitar com aquela trazida por uma "autoridade escolar": os autores do material didático, que gozam de prestígio no ambiente escolar. Por que o aluno deveria considerar o ponto de vista do seu professor correto e o livro didático errado?

Pareceu-nos necessário que o curso antecipasse tais diferenças e preparasse os estudantes para lidar com essa mudança e com o confronto entre o novo enfoque e a visão ainda predominante na educação científica. Desse modo, essa nova concepção de natureza da ciência que buscávamos ensinar não poderia ser simplesmente dita, proclamada. Julgamos indispensável que os alunos tivessem um contato significativo com esses conteúdos, no sentido de vivenciar algum tipo de conflito ou problematização que os envolvesse.

Buscamos contornar esse obstáculo de duas formas. Primeiramente, fomos levantando dúvidas sobre a concepção a ser criticada ao longo da apresentação dos slides e nos textos, e, ao mesmo tempo, fazendo provocações que instigassem os alunos a 
questioná-las (Apêndice C.2). Fomos introduzindo aos poucos os elementos que permitiriam propor uma visão alternativa, exemplificando o ponto de vista defendido.

O segundo recurso para contornar esse obstáculo foi enfatizá-lo na preparação da professora. Chamamos a atenção para o fato de que, além dos livros didáticos, a mídia, direta ou indiretamente, veicula uma concepção da natureza da ciência ultrapassada, justamente aquela que pretendíamos modificar. Orientamos a professora para discutir isso com os alunos, sempre que possível, alertando-os para as situações que comumente encontramos, como por exemplo, declarações de que "mais uma teoria científica havia sido comprovada". Acreditamos que é possível ao professor identificar situações para discutir as diferentes visões da construção do conhecimento científico, quando tem consciência desse desafio.

A possibilidade de surgirem outras concepções prévias não previstas também existia. Nesse caso, conseguimos antever duas situações. Idealmente, a preparação do professor deveria ser suficiente para que ele lidasse com alguns aspectos inesperados, podendo conduzir habilmente a discussão em sala de aula. Uma outra possibilidade é a atitude normalmente adotada por educadores quando um aluno questiona um tema desconhecido por ele: propor como uma pesquisa para os estudantes, ou dizer que desconhece a questão específica, que irá investigá-la e trará esclarecimentos na próxima aula. No nosso curso piloto, não seria possível propor pesquisas aos estudantes, dado o sistema modular de aulas em dias consecutivos. Não nos pareceu apropriado contar com esse recurso. Dessa forma, para essa situação em particular, caberia ao pesquisador que iria acompanhar o curso, orientar a professora nas possíveis lacunas no material didático. Em outros casos de aplicação desse curso ou propostas similares, caberá ao professor informarse das questões imprevistas.

\section{OC2. Falta de preparação do professor}

Preparar o professor das ciências para tratar aspectos filosóficos e históricos em sala de aula requer tempo, estratégias e material adequado. Na elaboração do curso sabíamos que a professora a aplica-lo não havia estudado tais conteúdos em sua formação. Desenvolver recursos que pudessem compensar a falta desse conhecimento específico suscitou muitas dúvidas: quais recursos seriam adequados? Quanto de aprofundamento adicional seria necessário apresentar no texto do professor em relação ao do aluno? Como 
prever possíveis dúvidas dos alunos e fornecer subsídios para o professor lidar com elas? Alguns aspectos eram mais evidentes, como as interpretações anacrônicas sobre conceitos, pessoas, e a ciência do passado, conforme descrevemos em obstáculos anteriores. Mas poderia haver situações imprevistas, como dúvidas epistemológicas dos alunos não previstas no material.

Utilizamos três recursos para dar apoio à professora. O primeiro deles foi discutir nas reuniões todos os pontos previsíveis como mais críticos; outro recurso foi exemplificar no texto de apoio certos "detalhes" que pudessem esclarecer esses pontos críticos; e, finalmente, elaboramos apresentações em slides para auxiliá-la nas aulas. Esse último recurso foi o único para o qual consultamos a professora. Os textos para os alunos e o próprio texto para o professor foram elaborados sem consultá-la, porque era parte da proposta da pesquisa vivenciar as dificuldades desse momento. Além disso, esse procedimento deveria ser autônomo e genérico, na medida do possível, para permitir que os resultados obtidos fossem replicados em outras situações. Os slides, todavia, consideramos como necessários para apoiá-la nas aulas. Apresentávamos a aula para a professora, e quando havia algum detalhe que poderia deixá-la mais insegura, ela pedia a inclusão de informações pontuais, para relembrá-la.

É importante destacar que nosso recorte para essa pesquisa não inclui a formação do professor. Tal linha de pesquisa possui referenciais teóricos próprios e esta tese teria outro encaminhamento se o objetivo fosse analisar a formação da professora. Portanto, nesse primeiro momento, as considerações sobre o professor configuram-se como dados descritivos realizados pelo pesquisador, que buscam registrar as dificuldades vivenciadas e soluções propostas, de modo a contribuir para a análise de dados dessa pesquisa. Estamos também buscando registrar esse processo de interação com a professora do modo mais detalhado possível para que, futuramente, possa ser analisado em desdobramentos desta pesquisa.

\section{OC3. Inadequação de textos especializados de história da ciência ao ensino médio}

Não é possível esperar que o aluno do ensino médio compreenda o trabalho que o historiador da ciência escreve voltado para seus pares. Na elaboração do curso piloto utilizamos esses trabalhos como saber de referência, entretanto, selecionar os aspectos fundamentais e descrevê-los de modo acessível aos alunos não foi elementar. Conforme 
havíamos apontado na dimensão teórica, a transposição didática dos saberes de referência para o Saber a Ensinar prevê os complexos processos de descontextualização (seção 2.3). Esses textos especializados são coerentes em si mesmos, possuindo uma estrutura argumentativa a explorar os detalhes históricos e científicos que permitam apresentar uma hipótese de trabalho e defendê-la, ou colocar uma questão e respondê-la. Tornar esse texto adequado ao estudante do ensino médio é bem mais do que meramente simplificar sua linguagem e omitir as informações "mais complicadas".

A vivência desse desafio permitiu-nos perceber aspectos que não devem ser abordados, enquanto outros não podem ser omitidos. O objetivo visado com o uso daquele conteúdo seria definir "o quê" e "como" deveria ser abordado, e não meramente excluir aspectos mais "difíceis" para o aluno entender. Um exemplo para esclarecer esse desafio é com relação ao experimento de Newton com o prisma. Os textos de referência (MARTINS; SiLVA, 2001; SiLVA; MARTINS, 2003) traziam vários detalhes dos experimentos realizados por Newton com o prisma, até propor sua explicação para a dispersão da luz branca em um prisma. Um dos objetivos dos autores era mostrar que foi um processo bastante complexo, sendo necessário formular hipóteses e realizar inúmeros experimentos, lidando com diversas variáveis até chegar a uma conclusão. A visão padrão em geral divulgada é a do experimentun crucis, que permitiu induzir sua teoria das cores.

Quando selecionamos esse conteúdo específico para o episódio II, pretendíamos criticar uma visão empírico-indutivista da ciência e reforçar a idéia da impossibilidade de observações neutras dos fenômenos. Esses textos traziam um conteúdo adequado para esse fim. Porém, o grande número de detalhes e os aspectos que fundamentavam a argumentação dos autores não seriam adequados ao nível de escolaridade enfocado. Por outro lado, não poderíamos simplesmente dizer: "Newton não realizou um único experimento, tampouco apenas experimentos, para concluir que a luz branca era uma mistura de sete cores. Ele utilizou hipóteses que guiaram seus procedimentos experimentais". Seria necessário construir uma argumentação que pudesse mostrar aos alunos os caminhos mencionados pelos autores. Mas, em que nível de simplificação? O que poderíamos omitir? O que deveríamos destacar?

A proposta para enfrentar esse desafio percorreu o seguinte caminho: em primeiro lugar, a professora fez a demonstração experimental da dispersão da luz pelo prisma. Olhou para a mancha colorida projetada na parede e começou a perguntar aos alunos: 
quantas cores vocês vêem? É possível distinguir onde termina uma cor e começa a outra? Por que será que a forma é alongada se o "buraco" por onde passa a luz é redondo? Dessa forma, antes de o aluno ter qualquer contato com o conteúdo a ser discutido, pretendíamos que ele se familiarizasse com o fenômeno, explorando possibilidades. Depois disso, a apresentação em slides (Apêndice D) explorava a interpretação corrente na época de Newton sobre o prisma modificar a luz. Fomos preparando o terreno para começar a relatar algumas das hipóteses aventadas por Newton e as sucessivas experiências que as derrubavam. Nesse momento, omitimos alguns detalhes, simplificamos outros, e "relatamos" proporções matemáticas sem fazer uma apresentação formal, tanto nos slides como no texto para os alunos (texto 4 para os alunos do curso piloto no Apêndice C).

Acreditamos que a combinação dessas estratégias: observar o fenômeno, acompanhar a apresentação em slides, e ler a sistematização no texto poderiam, conjuntamente, contornar o obstáculo enfrentado. Uma vez que a narrativa adequada desse episódio histórico escrita por especialistas não seria acessível aos alunos do ensino médio, foi necessário criar mecanismos para contornar esse problema.

OC4. Falta de pré-requisitos dos alunos em relação ao conhecimento matemático, físico, histórico, epistemológico e filosófico

Os conteúdos tratados no curso piloto eram todos novidade para os alunos, salvo alguns conhecimentos básicos de fenômenos ópticos como reflexão e refração da luz. Eles não conheciam os períodos históricos na dimensão necessária ao curso, nunca haviam estudado os conteúdos filosóficos ou epistemológicos a serem tratados, nem mesmo noções elementares que poderiam ser úteis para nossos propósitos. Além disso, não estudaram difração, superposição e interferência luminosas.

Era preciso desenvolver mecanismos para compensar tais deficiências. Para lidar com o conteúdo físico e com a omissão da matemática, realizamos demonstrações experimentais, fizemos breve revisão dos fenômenos ópticos em slides e apresentamos o filme Dr. Quantum (para auxiliar na compreensão da interferência luminosa). Sobre os aspectos históricos, mencionamos no texto apenas informações diretamente ligadas aos fenômenos discutidos, e decidimos por não investir na contextualização mais ampla do período. Infelizmente, muitos aspectos culturais do período foram omitidos. Para lidar com conteúdos filosóficos e epistemológicos, buscamos criar uma narrativa histórica que fosse apresentando, aos poucos, e na medida do possível, subsídios para os alunos entenderem os 
conceitos cruciais que seriam tratados. Utilizando exemplos da histórica da ciência, buscávamos ir apontando nas entrelinhas a dinâmica da construção do conhecimento, por exemplo, mostrando aspectos do debate corpúsculos ou vibrações no éter ocorrido no século XVII.

Lidar com a falta de pré-requisitos não impõe apenas desenvolver estratégias para compensar essa ausência nas coisas que se quer ensinar, mas também escolher o que se deve omitir. Fazer escolhas é muito difícil, mas necessário, já nos dizia Sir Richard Livingstone: "Se reconhece um bom professor pelo número de temas valiosos que se abstém de ensinar" (apud CHEVALlARD, 1991, p. 54).

Omitir a matematização foi ponto nevrálgico durante a elaboração do curso, uma vez que admitimos a matemática como estruturante do pensamento físico (PIETROCOLA, 2002). O que realmente se conhece de uma explicação para um fenômeno físico sem a abordagem matemática?

Não foi possível evitar o pesar sobre temas interessantes que o aluno, provavelmente, não terá oportunidade de aprender. Foi o caso, principalmente, das contribuições árabes durante a Idade Média, do peculiar cenário cultural permeando influências místicas e teológicas na obra de Newton, e o interessante aspecto do arrastamento parcial do éter pelos corpos transparentes na teoria de Fresnel.

\section{OC5. Possível concepção prévia dos estudantes e professores sobrevalorizando a capacidade da ciência atual em resolver todos os problemas}

A concepção da capacidade da ciência atual de resolver todos os problemas é uma das facetas do anacronismo que vem sendo discutido em diferentes desafios e propostas. Posto aqui de forma mais genérica, foi contornado, basicamente, como os demais. No material didático, buscamos mostrar a pertinência das idéias e dos recursos utilizados em cada época, procurando valorizá-los em seu contexto. Na preparação da professora, enfatizamos as possíveis facetas com que essa visão poderia se materializar, orientado-a para administrá-las.

OC6. Enfatizar aspectos científicos ou enfatizar fatores externos à ciência

Esse obstáculo é bastante complexo em função dos desdobramentos de suas possíveis soluções. Ele pode ser considerado um conflito, ou mesmo um dilema em 
algumas situações. Há dois objetivos estabelecidos para o curso piloto que justificariam a necessidade de enfatizar aspectos externos à ciência.

Um deles é quando se pretende mostrar a influência de fatores extra-científicos na construção da ciência, visando criticar a visão empírico-indutivista. Para problematizar essa concepção de ciência utilizamos dois pilares: (i) mostrar a impossibilidade de conclusões neutras e objetivas a partir da observação de fenômenos e experimentos; (ii) mostrar a influência de fatores não científicos na aceitação de idéias, teorias e metodologias. Tais estratégias, entretanto, envolvem riscos, como por exemplo, o relativismo, quando se desvaloriza demasiadamente a experimentação. $\mathrm{Ou}$ ainda, atribuir a grande aceitação das idéias de Newton no século XVIII, apenas ao seu prestígio. Mais do que o dilema entre enfatizar um ou o outro, existe o desafio de contrabalançar ambas as informações. Quanto enfatizar de cada um? Como minimizar riscos de interpretações equivocadas? Até que ponto é possível atuar nessa mediação?

O outro objetivo de se utilizar conhecimentos de fatores não científicos no curso piloto seria promover uma compreensão do contexto. Na perspectiva historiográfica, é necessário contextualizar qualquer conteúdo da ciência para abordá-lo. Tal contextualização pode ser feita mediante aspectos internos à ciência, por exemplo, analisando outras teorias do período, o procedimento de outros "cientistas", outras metodologias para investigar o mesmo fenômeno, as idéias que influenciaram a elaboração de determinado conceito etc. Nesse caso, compreender uma idéia da ciência em seu contexto, é compreendê-la na perspectiva conceitual. Ainda que implicitamente, ao estudar como procediam o pesquisador e seus pares, está-se criando o quadro teórico da época enfocada. Outra forma de contextualizar um conteúdo científico é entendê-lo na perspectiva cultural. Que valores, idéias, crenças de uma determinada sociedade influenciaram na elaboração de uma determinada teoria? Que necessidades políticas ou econômicas motivaram o desenvolvimento de determinados conceitos, teorias ou mesmo ramos da ciência?

No curso piloto não foi possível contextualizar, de nenhum modo, sob o ponto de vista historiográfico. Porém, conforme já dissemos, os saberes produzidos de historiadores para historiadores e os saberes voltados ao ambiente escolar possuem funções sociais distintas. Nosso modo de superar ou contornar esses obstáculos foi primeiramente estabelecendo que não havia tempo para discutir aspectos históricos e científicos do 
período. Depois disso, separamos essa complexa discussão em obstáculos menores e buscamos solucionar/contornar cada um deles.

A tentativa de contextualização de cada um dos episódios históricos foi feita mediante a comparação de teorias e idéias defendidas por pensadores contemporâneos, buscando adequar essa discussão ao ensino médio, naturalmente. Esses pontos são explorados em outros desafios discutidos, pois, como dissemos, alguns deles apresentam aspectos sobrepostos, mas optamos por explorar o maior número possível de suas facetas.

Para mostrar algumas influências de fatores não científicos, utilizamos basicamente o prestígio de Newton e o apoio de Arago a Fresnel, mas, em ambos os casos, buscamos destacar outros méritos das idéias, como a rigorosa matematização, o poder explicativo das teorias, os inúmeros experimentos realizados (veja textos no Apêndice $\mathrm{C}$ e slides no Apêndice D). Tais desafios também foram discutidos outras vezes.

\section{OC7. Quantidade da informação na forma de textos}

A preparação de um material em história e filosofia da ciência para o ensino médio requer que o conteúdo seja sistematizado em textos para os alunos. Ainda que possamos lançar mão de diversas atividades diferentes para discuti-lo (conforme propusemos no curso piloto), é necessário que uma organização das idéias seja registrada de forma que o aluno possa compreendê-las. Ao invés de ilustrações, fórmulas, gráficos e exercícios habituais no ensino da física, lidávamos com conteúdos históricos e filosóficos. Durante a elaboração do curso houve uma preocupação em não sobrecarregar os alunos com a quantidade de textos, pois a leitura não é uma prática comum entre os estudantes do ensino médio.

A professora confirmou a falta do hábito de leitura dos estudantes. Entretanto, esse foi um risco que decidimos assumir. No contexto de aplicação do curso piloto, não havia outra maneira de garantir o contato do aluno com o conteúdo sistematizado de modo a atender os objetivos do curso. Decidimos arriscar, entregando aos alunos nove textos para leitura, incluindo o roteiro para o teatro. Supúnhamos que os alunos do ensino médio estranhariam uma "grande" quantidade de textos (cerca de 40 páginas) para estudar em apenas 10 dias consecutivos.

Adotamos a estratégia de realizar a leitura junto com os alunos durante as aulas, somente depois de ter tido seu conteúdo trabalhado em atividades didáticas diferentes. 
Desse modo, a leitura era uma organização dos conceitos já discutidos em distintas estratégias pedagógicas.

\section{OC8. Extensão versus profundidade}

Adotar a abordagem recortada dos episódios históricos sem perder de vista a compreensão panorâmica da história foi um desafio a enfrentar. A nossa opção para tratar a história da ciência é pelo recorte, estabelecido desde o quadro teórico (capítulos 1 e 2). As grandes sínteses são as versões que, em geral, apresentam mais problemas na interpretação da história da ciência. A tentativa de elaborá-las traz normalmente uma reconstrução racional, que tende a estereotipar atores e simplificar demasiadamente os fatos. O risco de adotar visões problemáticas, anacrônicas e permeada por juízos de valor é muito grande (Allchin, 2004; KraGH, 1987; Kuhn, 1997; Martins, L., 2005; Martins, R., 2004)). A opção pela extensão é própria da tentativa de utilizar a história da ciência para se ensinar ciências e está vinculada à concepção historiográfica presente no ambiente escolar (seções 1.2.2 e 1.2.3). De um modo geral, professores e autores de livro didático não foram formados em história da ciência, então é normal que perpetuem a história da ciência que conheceram. Cabe aos especialistas a tarefa de investir na divulgação das interpretações da história da ciência, orientadas segundo a historiografia contemporânea.

Havia entretanto, a preocupação com a autonomia do aluno em localizar temporalmente os episódios a serem tratados. "O olhar aproximado nos permite captar algo que escapa da visão de conjunto, e vice-versa" (GINZBURG, 2006, p. 267). Conforme destaca o historiador Ginzburg, é necessário, na medida do possível, a visão da parte e do todo. Desse modo, julgamos necessário desenvolver uma estratégia pedagógica que pudesse favorecer o entendimento da localização histórica de cada episódio (seção 3.2.7).

Optamos pela utilização do recurso "linha do tempo", descrita na seção 3.2.5, com imagens de pensadores e de filmes históricos, para permitir ao aluno localizar de modo relativamente rápido a época em que ocorreu cada episódio tratado pelo curso (Apêndice D.2). ${ }^{18}$

\footnotetext{
18 Havíamos utilizado tal recurso, lançando mão de filmes históricos para promover a localização dos períodos, nas aulas de História de Ciência que ministramos na Universidade Ibirapuera em 2005 e 2006. Trabalhamos com diferentes turmas e os resultados obtidos foram positivos. A proposta original foi ampliada
} 
Nossa hipótese nessa proposta foi admitir que conciliar o recorte histórico dos episódios, prescrito pela metodologia e historiografia da história da ciência, com uma visão panorâmica de todo o processo, permitiria atender aos requisitos do ambiente escolar. Em outras palavras, esse recurso pedagógico traria uma proposta para lidar com um possível conflito entre extensão e profundidade em abordagens históricas. Ao mesmo tempo que um conteúdo da história da ciência fosse enfocado diacronicamente, a linha do tempo permitiria "visualizar" o momento histórico em que ocorreu e apontar para o contexto cultural adjacente.

\subsection{Análise da aplicação do curso: a construção dos eventos de pesquisa}

Apresentamos na seção anterior os desafios enfrentados durante a elaboração do curso piloto, que se configuram como resultado da primeira etapa da parte empírica da pesquisa. Faremos a seguir a análise de três eventos decorrentes da aplicação do curso piloto em sala de aula, ou seja, a segunda etapa da pesquisa empírica.

O curso piloto alternou aulas mais expositivas, durante as quais se introduziam os três episódios históricos selecionados ou momentos de sistematização das questões propostas, com momentos de atividades dinâmicas - como o debate, o teatro e o festival cultural. Houve também aulas com demonstrações experimentais de fenômenos ópticos, com textos entregues recortados em parágrafos, como um quebra-cabeça, e momentos para responder às questões finais em cada episódio.

De modo geral, podemos considerar que a aplicação da sequiência didática apresentou bons resultados, sob vários aspectos. Os alunos mostraram-se engajados nas atividades, na problemática discutida e no tema do curso. Na última aula do módulo, os estudantes agradeceram a oportunidade do aprendizado. Seus comentários no questionário inserido na avaliação final do curso demonstraram que eles sentiam-se prestigiados e privilegiados em aprender o conteúdo do curso. A professora mostrou-se entusiasmada com o conteúdo e com as inovações metodológicas e os desafios a eles subjacentes. Ela empenhou-se na leitura dos textos e no aprendizado do novo conteúdo, e mostrou-se

na linha do tempo desenvolvida para esse curso piloto. Tal linha pode ser vista no corredor do Bloco B da FEUSP, no corredor de Ensino do IFUSP e está disponível em:

<http://nupic.incubadora.fapesp.br/portal/projetos/historia-da-fisica/imagem-3/TEMPO_LINHA.jpg>. 
satisfeita com os resultados e com o transcorrer das aulas. Nas nossas reuniões durante o curso, ela fazia comentários do tipo: "eu estou achando que estamos indo bem, os alunos estão curtindo, você notou?”. Em outras ocasiões ela comentava: “nossa, eu sempre quis trabalhar com história da ciência, que bom ter dado certo... estou adorando o assunto do curso".

A repercussão do curso na escola foi bastante positiva. Os alunos de outra sala de terceiro ano foram queixar-se à direção que gostariam de ter sido selecionados para a aplicação do curso piloto. Esclareceu-se que a professora daquela turma escolhida é quem estava vinculada ao grupo de pesquisa do Nupic-Feusp, por isso apenas uma classe teve, naquele primeiro momento, a possibilidade de participar.

Do ponto de vista da pesquisa, o curso trouxe informações importantes também quando mostrou a necessidade de aperfeiçoar o material didático, o planejamento das aulas, e apontou algumas lacunas na preparação desenvolvida com a professora. Tais aspectos serão destacados ao longo da análise dos eventos.

Percebemos que, mesmo em aulas expositivas, supostamente as mais "monótonas", a maioria da sala permanecia atenta e comprometida com a problemática. Alguns alunos normalmente menos interessados, aqueles menos envolvidos nas primeiras aulas, foram se engajando nas atividades ao longo do curso. Começaram a participar ativamente nas aulas, integrar os debates, levantar questões, e continuaram a apresentar um comportamento de maior comprometimento, mesmo quando o curso terminou, conforme a professora relatou.

Após o término do curso, tivemos ainda algumas reuniões com a professora, em que ela descreveu a mudança de comportamento dos alunos no sentido de maior engajamento com os conteúdos, inclusive nos assuntos tratados posteriormente.

Os resultados acima podem fazer crer que, do ponto de vista da aplicação, o curso piloto foi um sucesso! No entanto, interessa-nos, como pesquisadora, entender como os obstáculos anteriormente discutidos puderam ou não ser superados e contornados. Ou seja, o foco principal da análise que esta pesquisa se propõe recai sobre o entendimento do processo de didatização. Isso exige um revisitar os dados obtidos na aplicação do curso, buscando elementos que permitam resultados mais específicos sobre esse processo e, portanto, menos gerais em termos de análise. 
O curso piloto foi organizado de forma que cada episódio fornecesse conteúdos históricos e epistemológicos, visando a problematizar aspectos da natureza da ciência, bem como preparar o aluno para as discussões vindouras. A seqüência de atividades didáticas foi pensada para promover o contato do aluno com um mesmo objetivo epistemológico mais de uma vez, buscando favorecer a reflexão e o amadurecimento dos conceitos trabalhados. Por essa razão, não há atividades autônomas no curso, isto é, nenhuma atividade foi pensada para ser auto-suficiente em relação aos propósitos pedagógicos do curso.

Dessa forma, as unidades de análise não seriam naturalmente as atividades ou episódios históricos do curso. Isso requereu selecionar, usando critérios baseados no referencial teórico, algumas seqüências de interação sujeitos-saber, para que fosse possível completar um ciclo, para responder às questões levantadas (CARVALHO; GonÇALVES, 2000). A seleção de um único aspecto pontual em uma única aula não poderia contemplar dados suficientes para uma análise que pretende compreender o processo de interação na relação didática, no caso dessa pesquisa. Estas seqüências de interação são os "eventos de pesquisa", que passaremos a analisar abaixo.

A seleção desses três eventos foi realizada, principalmente, em decorrência do contato íntimo com os dados gravados e escritos. Inicialmente, nossa intenção para com a análise dos dados era observar como os aspectos da natureza da ciência selecionados (seção 1.2.4) haviam se materializado na sala de aula, e como os alunos interagiram com eles. Interessava-nos também, averiguar as conseqüências das soluções propostas para superar ou contornar os obstáculos estruturais na elaboração da proposta. Durante a análise dos dados, as questões envolvendo esses três eventos mostraram-se dignas de serem privilegiadas para a análise discutida nesta tese. Eles reúnem condições para identificar a interação dos alunos com o conteúdo epistemológico, a atuação da professora na transposição didática interna, e mostram como alguns obstáculos foram superados ou contornados, além, é claro, de apontar limitações e aspectos a melhorar na proposta.

\subsubsection{Evento Gregos}

Na elaboração do material didático e construção de atividades pedagógicas para a criação do curso, enfrentamos inúmeros desafios inerentes a todo o processo, como a textualização, seleção de aspectos a enfatizar ou a omitir, falta de pré-requisitos conceituais 
dos alunos, dentre outros. Além dos desafios comuns aos três episódios históricos, surgiram obstáculos estruturais específicos dos conteúdos de cada período.

Para abordar as teorias da luz na Antiguidade grega lidamos com conteúdos históricos, filosóficos e contextuais bastante complexos para serem compreendidos por estudantes do ensino médio. Buscamos construir narrativas históricas e atividades pedagógicas para lidar com dificuldades próprias a esse conteúdo (seção 4.1). Os obstáculos estruturais relativos aos conteúdos específicos da Antiguidade que buscamos superar ou compensar foram principalmente: ${ }^{19}$

- levar em conta as diferenças entre a concepção de ciência em distintas épocas e nas diferentes ciências (OS8);

- existência de conteúdos da história da ciência que não são de fácil compreensão para uma pessoa na atualidade (OS8);

- dificuldade de tratar diacronicamente pensadores de épocas e culturas diferentes das nossas (OS8);

- falta de pré-requisitos dos alunos em relação ao conhecimento científico, histórico, epistemológico e filosófico (OC4);

- possível concepção prévia dos estudantes e professores sobrevalorizando a capacidade da ciência atual em resolver todos os problemas (OC5).

Nossa intenção inicial para a análise dos dados era averiguar até que ponto as escolhas foram bem sucedidas ao lidar com tais obstáculos, e se foi possível problematizar os aspectos da natureza da ciência selecionados. Entretanto, logo no contato inicial com alguns dados desse episódio evidenciou-se uma questão fundamental, a que, embora previsível dentro do quadro teórico adotado, não havíamos, inicialmente, dado a devida importância.

Após o segundo dia de curso, iniciamos a leitura das respostas dos alunos às questões do texto 2. A quase totalidade das respostas sugeria que eles haviam aceito com muita naturalidade o fato de haver mais de uma teoria proposta pelos filósofos para explicar o fenômeno visual. Mais do que isso, emergiu uma visão "relativista” de que

\footnotetext{
${ }^{19}$ Veja o que foi proposto no planejamento do curso e nos textos 1 e 2 para o aluno no Apêndice C, os slides "gregos" no Apêndice D, e, a discussão do enfrentamento dos desafios na seção 4.1.
} 
qualquer opinião poderia ser aceitável. Vinculada a essa concepção, parecia haver uma interpretação anacrônica de que, em épocas passadas, seria justificável a ausência de consenso entre os filósofos.

Para analisar esse evento (episódio de ensino), consideramos importante averiguar o contato dos alunos com os conteúdos desse episódio histórico do curso, ministrados anteriormente. Isso implicou analisar a interação dinâmica ocorrida entre os elementos da relação didática (alunos - professor - saber) que precedeu a manifestação dessa opinião e poderia ter contribuído para tais concepções. Desse modo, o material didático e a atuação do professor na transposição didática interna integram o universo de dados vinculado a esse evento que chamamos de Evento Gregos.

Depois de apresentar esse evento, vamos analisar os dados, buscando compreender de que modo as variáveis envolvidas na elaboração do Saber a Ensinar podem ter contribuído para tal interpretação, e, na medida do possível, averiguar a influência de concepções prévias dos alunos.

O risco de um relativismo já havia sido previsto pelo quadro teórico (seção 2.3.2). Durante a elaboração dos textos para os alunos, buscamos construir uma narrativa histórica que pudesse minimizar tal risco. Ao longo de todo o texto, preocupamo-nos em vincular as distintas explicações para a natureza da luz às diferentes escolas de pensamento. Apresentamos as idéias centrais da concepção de mundo de cada pensador e sua relação com a sua explicação para a luz e a visão, reforçando concepção nos parágrafos finais do texto 2:

[...] Havia muitas teorias para tentar explicar o fenômeno visual nesse período. Todos estavam pensando sobre os mesmos fenômenos ópticos, buscavam entendê-los utilizando raciocínios lógicos e matemáticos, porém, cada filósofo fornecia sua própria explicação para a luz e a visão. Será que há algo de estranho nisso? Por que não havia um consenso?

Parece que apenas observar o comportamento da natureza $e$ pensar racionalmente sobre os fenômenos propiciou o surgimento de diferentes explicações. Entretanto, os filósofos elaboravam teorias que estavam relacionadas a essas observações, ou seja, não era apenas 
questão de opinião pessoal. [...]. (Texto 2 para os alunos Apêndice C.2, grifos no original).

Das questões colocadas ao final do texto 2 (Apêndice C.2), voltadas a esse episódio histórico, pode-se considerar que uma delas permitiu a manifestação da visão relativista predominante nas respostas dos alunos:

A natureza fornece informações que permitem uma única interpretação? Explique.

Vejamos algumas respostas escritas pelos alunos para a questão 3, que representam a visão da maioria dos alunos:

Aluno 1: Não. A natureza fornece fenômenos com informações infinitas. No entanto, o ato da interpretação cabe a quem estuda essas informações, podendo considerar qualquer uma: afinal cada pessoa pensa de um jeito. (grifo nosso)

Aluno 2: Não, na natureza há vários tipos de fenômenos e transformações, e cada pessoa ao tentar interpretar esses fenômenos pode tirar conclusões, sendo elas diferentes pois cada um vê o mundo e analiza os fatos de forma própria defendendo sua forma de pensar, mas cada fenômeno da natureza possui uma forma mais adequada e aceitável de ser explicada. (grifo nosso)

Aluno 3: As informações que a natureza fornece é a mesma, cada pessoa tem uma lógica de raciocínio diferente, possibilitando assim as várias interpretações. (grifo nosso)

Aluno 4: Não, pois assim como os filósofos, nós seres humanos interpretamos as coisas de forma diferentes até por que não somos iguais. E é isso que colabora p/ evolução de teorias. (grifo nosso).

Ao final daquela aula, quando realizamos a leitura desse material, consideramos que os alunos que responderam colocando idéias semelhantes às do aluno 2 , reproduzida acima, haviam compreendido o enfoque pretendido. Por outro lado, as respostas similares às do aluno 1 eram em maior número, e indicavam uma concepção relativista. As respostas do mesmo tipo, dos alunos 3 e 4, sugeriam a concepção relativista. 
Pelas anotações efetuadas em nosso caderno de notas, ${ }^{20}$ havia, já naquele momento, uma preocupação de que a atuação da professora, na transposição didática interna, ou o material didático, tivessem sugerido um relativismo. Ao mesmo tempo que os alunos descreviam com tranqüilidade a impossibilidade de observações neutras, não ficava claro se haviam compreendido que cada teoria estava vinculada a diferentes escolas de pensamento. Registramos naquela ocasião a crença de que o texto 2 , a fundamentar esse conteúdo, falaria claramente que não é uma questão de opinião pessoal. Entretanto, de acordo com as anotações de campo, esperávamos que a continuação do curso poderia ser capaz de modificar essa concepção relativista.

O primeiro passo para analisar o Evento Gregos foi verificar os momentos de contato entre os elementos da relação didática antecedente à resolução das questões do texto 2 (Apêndice C.2).

A cada dia os alunos tinham duas horas-aula. No primeiro dia de aula (aulas 1 e 2), quando os alunos realizaram o jogo "Colocando na linha do tempo", a professora apresentou a linha do tempo, e depois os alunos montaram o quebra-cabeça do texto 1 (Apêndice C.2). Talvez essa introdução ao curso tenha pré-disposto os alunos a interpretarem que a existência de teorias concorrentes seja algo inerente à investigação da natureza, com um viés relativista. Por outro lado, pretendíamos enfatizar que houve a elaboração de diversas teorias ao longo da história, e todas apresentavam sucesso em explicar alguns fenômenos, mas também possuíam limitações. O risco de apresentar esse ponto de vista é sugerir uma visão equivocada da ciência, como se evoluísse linearmente, construída por infalíveis gênios, até chegar ao patamar atual. Tal concepção retrataria um dos obstáculos previstos: OC5: Possível concepção prévia dos estudantes e professores sobrevalorizando a capacidade da ciência atual em resolver todos os problemas (seção 4.1).

No segundo dia de curso (aulas 3 e 4), ocorreu o Evento Gregos. A professora iniciou a aula com a apresentação em slides "Gregos" (Apêndice C.3). Como a explicação é longa, extraímos as falas da professora $(\mathrm{P})$ que nos pareceram mais relevantes. A transcrição completa encontra-se no Anexo A.

\footnotetext{
${ }^{20}$ Anotações de campo do dia 10/9/2007.
} 


\begin{tabular}{|c|c|c|c|}
\hline \multicolumn{4}{|c|}{ 10/9/2007 - Aulas 3 e 4 - Arquivo I } \\
\hline Turno & Tempo & Falas & Observações \\
\hline 4 & $03: 27$ & $\begin{array}{l}\text { P: Bom! Então como eu tinha falado para vocês, } \\
\text { [...] nós vimos que luz é onda eletromagnética. Mas } \\
\text { será que ela sempre foi, vista como onda } \\
\text { eletromagnética? Então será que sempre foi assim? } \\
\text { Como os homens da ciência, que são todos } \\
\text { aqueles que tão lá naquela faixa, como será que } \\
\text { eles explicaram o que é a luz? Como povos de } \\
\text { outras épocas entendiam e explicavam isso? Vocês } \\
\text { acham que todo mundo sempre deu a mesma } \\
\text { explicação? }\end{array}$ & $\begin{array}{l}\text { Novamente } \\
\text { ênfase } \\
\text { equivocada em } \\
\text { "todos". }\end{array}$ \\
\hline 5 & 04:06 & $\begin{array}{l}\text { Alunos: Não... (alguns alunos murmuram baixo, } \\
\text { olhado para a projeção). }\end{array}$ & \\
\hline 6 & 04:08 & $\begin{array}{l}\text { P: Bom! Na época dos gregos, o que chamava } \\
\text { muita atenção deles? A luz que vinha das estrelas. } \\
\text { E lembrando que na época deles, lá em } 500,600 \\
\text { a.C, o Sol... o Universo... observar as estrelas } \\
\text { deveria ser muito mais bonito do que é para nós } \\
\text { hoje, por que eles não tinham interferência de } \\
\text { poluição. [...] No século VII a.C., relembrando } \\
\text { também o que eu tinha comentado, eles } \\
\text { acreditavam que tudo era vontade dos deuses. } \\
\text { Então se chovia, era por que o deus da chuva } \\
\text { estava mandando chuva para os homens. Tanto } \\
\text { eram coisas boas, como eram castigos aos homens. } \\
\text { Lembrando do filme Tróia e aqueles filmes que } \\
\text { estavam como referência, tá? Só que no século VI } \\
\text { a.C. eles começaram a questionar, a querer } \\
\text { entender como é que os fenômenos aconteciam. } \\
\text { [...] Então no século VI a.C., que é quando } \\
\text { nasceu a filosofia, eles estavam tentando } \\
\text { explicar alguns fenômenos através do } \\
\text { pensamento e da razão. E aí, para luz, que é o } \\
\text { foco do nosso curso, eles começaram a levantar } \\
\text { algumas questões: Então porque a gente só enxerga } \\
\text { quando está claro? Do que depende a visão? O que } \\
\text { acontece entre o nosso olho e a nossa mente para } \\
\text { que a gente consiga ver os objetos? Será que sai } \\
\text { alguma coisa do olho para gente conseguir } \\
\text { enxergar? Ou será que entra alguma coisa no olho? } \\
\text { Como é esse processo de visão? Então esses são } \\
\text { exemplos de perguntas que eles começaram a se } \\
\text { questionar. E aí eles começaram a elaborar } \\
\text { teorias, ou elaborar explicações. }\end{array}$ & $\begin{array}{l}\text { Grifos nossos: } \\
\text { retoma texto le } \\
\text { enfatiza o filme } \\
\text { pertinente. Boa } \\
\text { iniciativa da } \\
\text { professora. } \\
\text { Procuramos } \\
\text { enfatizar nas } \\
\text { reuniões de } \\
\text { preparação com } \\
\text { a professora que } \\
\text { ela insistisse na } \\
\text { visão sobre } \\
\text { “elaborar } \\
\text { explicações" e } \\
\text { “elaborar } \\
\text { teorias” para } \\
\text { contrapor a } \\
\text { idéia do senso } \\
\text { comum de } \\
\text { “descobrir as } \\
\text { leis naturais”. } \\
\text { Nesse sentido, } \\
\text { nota-se atuação } \\
\text { adequada da } \\
\text { professora na } \\
\text { transposição } \\
\text { didática interna. }\end{array}$ \\
\hline 7 & $06: 41$ & $\begin{array}{l}\text { P: Bom! Nós vamos focalizar em alguns deles. Tá? } \\
\text { Então a gente vai citar os atomistas. Dentre eles } \\
\text { estão o Leucipo, em } 500 \text { a.C., o Demócrito, o } \\
\text { Epicuro e o Lucrécio. Então todos eles eram }\end{array}$ & $\begin{array}{l}\text { Nos slides } \\
\text { consta a época } \\
\text { em que cada um } \\
\text { teria vivido. }\end{array}$ \\
\hline
\end{tabular}




\begin{tabular}{|c|c|c|c|}
\hline & & $\begin{array}{l}\text { atomistas e eles começaram a elaborar as } \\
\text { explicações para tentar entender o que era a luz e } \\
\text { como é esse processo de visão. Bom! Para eles, } \\
\text { que eles eram da filosofia atomista... [...] Que } \\
\text { eles disseram que, que tudo, tudo que se tem de } \\
\text { matéria, é formado por átomos e que o átomo era a } \\
\text { menor partícula. Eles não tinham ainda a idéia do } \\
\text { elétron, nem do próton, nada, acabava no átomo. } \\
\text { [...]. Tudo era formado por combinações diferentes } \\
\text { de átomos. E eles foram os primeiros que não } \\
\text { aceitavam um universo totalmente preenchido por } \\
\text { matéria. Eles acreditavam que tinha lugares onde } \\
\text { existia o vazio por completo, tá? Então essa era a } \\
\text { idéia dos atomistas. }\end{array}$ & $\begin{array}{l}\text { A apresentação } \\
\text { das idéias } \\
\text { principais dos } \\
\text { atomistas visava } \\
\text { relacionar as } \\
\text { explicações para } \\
\text { a luz e a visão à } \\
\text { sua concepção } \\
\text { de mundo, ao } \\
\text { seu sistema de } \\
\text { pensamento. }\end{array}$ \\
\hline 8 & $08: 29$ & $\begin{array}{l}\text { P: Bom! [...]. Então o que era a luz para o } \\
\text { Leucipo? Lembrando, gente, que é em } 500 \text { a.C., } \\
\text { tá? Então, pode ser que com o que eu vá falar da } \\
\text { idéia dele, vocês fiquem meio assim, mas eu vou } \\
\text { querer a opinião de vocês. O que o Leucipo dizia? } \\
\text { Que a gente enxerga os materiais porque sai } \\
\text { alguma coisa dos materiais que entra nos nossos } \\
\text { olhos. Então um exemplo: eu enxergo a televisão } \\
\text { porque saem miniaturinhas, miniaturas muito } \\
\text { pequenininhas de televisão, que vêm viajando aqui, } \\
\text { e entram no meu olho. Então eu enxergo a Gisele } \\
\text { porque a Gisele está emitindo miniaturas de Gisele } \\
\text { (pausa, alunos riem) que chegam no meu olho, e aí } \\
\text { eu enxergo a Gisele (risos dos alunos). }\end{array}$ & $\begin{array}{l}\text { A professora } \\
\text { enfatiza a época } \\
\text { antes de } \\
\text { apresentar a } \\
\text { teoria e já } \\
\text { "previne”os } \\
\text { alunos que eles } \\
\text { poderiam achar } \\
\text { as teorias } \\
\text { “estranhas". } \\
\text { A partir dos } \\
\text { gestos de } \\
\text { algumas alunas } \\
\text { é possível } \\
\text { perceber que } \\
\text { elas discutem a } \\
\text { teoria recém } \\
\text { apresentada. }\end{array}$ \\
\hline 9 & 09:31 & $\begin{array}{l}\text { Aluno: Isso é impossível professora! } \\
\text { Alunos falam baixo ou fazem gesto de negação com } \\
\text { a cabeça, enquanto a professora apresenta o } \\
\text { exemplo relacionado a aluna Gisele. }\end{array}$ & \\
\hline 10 & $09: 34$ & $\begin{array}{l}\text { P: Então, ó o que era luz para o Leucipo? Algo } \\
\text { material. Porque se é... miniaturas de Gisele, é } \\
\text { material, certo? Sai dos objetos, de tudo, da parede, } \\
\text { da luz, da cortina e entra no meu olho provocando } \\
\text { a visão. Então para ele a luz era uma emanação. } \\
\text { Alguma coisa que sai dos objetos e entra nos olhos. } \\
\text { Isso que entra nos olhos tinha forma, tinha cor e } \\
\text { tinha tamanho. Então aqui é uma representação do } \\
\text { que era a luz para o Leucipo. Ele deu o nome de } \\
\text { eidolas. Tá? Então todos os objetos emanavam } \\
\text { eidolas que seriam assim como esse gatinho aqui. } \\
\text { Ele emana miniaturas de gatinhos iguais a ele, aí } \\
\text { essas miniaturas chegam no olho e a gente enxerga } \\
\text { o gato. Essa é a teoria do Leucipo. }\end{array}$ & $\begin{array}{l}\text { Professora } \\
\text { mostra uma } \\
\text { imagem que } \\
\text { representa a } \\
\text { teoria de } \\
\text { Leucipo. } \\
\text { Avisar } \\
\text { professora de } \\
\text { que "Eidola" é } \\
\text { plural de } \\
\text { "Eidolum". }\end{array}$ \\
\hline
\end{tabular}


$\mathrm{Na}$ apresentação inicial do período e das concepções dos atomistas para explicar a luz, não percebemos nada na fala da professora que pudesse fomentar um relativismo, ou ainda, que a existência de diferentes teorias fosse meramente questão de opinião pessoal. Parece-nos que ela estava preocupada com a reação dos alunos perante as idéias da Antiguidade, com o comentário feito no turno 8:

Então, o que era a luz para o Leucipo? Lembrando, gente, que é em 500 a.C., tá? Então, pode ser que com o que eu vá falar da idéia dele, vocês fiquem meio assim, mas eu vou querer a opinião de vocês (turno 8).

Aparentemente considerando que a explicação causaria estranheza aos alunos, a professora antecipou-se em advertir que iria solicitar suas opiniões. Podemos levantar algumas hipóteses para a atitude da professora, por exemplo, se as idéias pareceram estranhas até mesmo para ela, por que os alunos também não as achariam? Ou ainda, mesmo tendo a professora compreendido que aquelas idéias eram adequadas ao contexto de um passado distante, ela própria esperaria que tais concepções causassem estranheza aos alunos.

De qualquer modo, a professora coloca uma pergunta para a classe, e, nesse momento, ela atua na transposição didática interna de modo a lidar com os obstáculos estruturais que buscamos superar e contornar, por exemplo, enfatizando a complexidade do tema:

\begin{tabular}{|c|c|c|c|}
\hline \multicolumn{4}{|c|}{ 10/9/2007 - Aulas 3 e 4 - Arquivo I } \\
\hline Turno & Tempo & Falas & Observações \\
\hline 11 & $10: 35$ & $\begin{array}{l}\text { P: Agora vem a pergunta. Vocês conseguem } \\
\text { enxergar... Essa é a explicação dele. Mas eu } \\
\text { quero... Lembrando, gente, que não é fácil! Se } \\
\text { vocês parassem para pensar... Se eu perguntasse } \\
\text { para vocês agora o que é a luz, sem lembrar } \\
\text { daquela história que eu já dei para vocês, que... que } \\
\text { ela é onda eletromagnética... se vocês tivessem que } \\
\text { parar para pensar o que é a luz, com certeza cada } \\
\text { um ia dar a sua explicação aqui. Certo? }\end{array}$ & $\begin{array}{c}\text { Professora } \\
\text { enfatiza a } \\
\text { complexidade } \\
\text { do tema. }\end{array}$ \\
\hline 12 & $11: 12$ & Jade : éh.... & $\begin{array}{l}\text { Jade faz sinal } \\
\text { afirmativo com } \\
\text { a cabeça, sorri } \\
\text { e coloca a mão }\end{array}$ \\
\hline
\end{tabular}




\begin{tabular}{|c|c|l|c|}
\hline & & \multicolumn{1}{|c|}{\begin{tabular}{c} 
no rosto. \\
\hline 13
\end{tabular} $11: 13$} & $\begin{array}{l}\text { P: Mas eu quero saber de vocês o seguinte: vocês } \\
\text { conseguem enxergar algum problema na teoria do } \\
\text { Leucipo? } \\
{[\ldots]}\end{array}$ \\
$\begin{array}{l}\text { P: Você acha que assim... Tá simples? Que basta } \\
\text { essa explicação? Vocês conseguem ver algum } \\
\text { problema nessa explicação? }\end{array}$ & $\begin{array}{c}\text { Ginal afirmativo } \\
\text { com a cabeça. }\end{array}$ \\
\hline
\end{tabular}

A fala da professora no turno 11 busca chamar a atenção dos alunos para a complexidade da questão. Ele recorre à estratégia de lembrá-los das concepções atuais sobre ondas eletromagnéticas, e como cada um explicaria a luz sem ter esse conhecimento. A atuação da professora motivou os alunos a darem respostas questionando a teoria de Leucipo.

\begin{tabular}{|c|c|c|c|}
\hline \multicolumn{4}{|c|}{ 10/9/2007 - Aulas 3 e 4 - Arquivo I } \\
\hline Turno & Tempo & Falas & Observações \\
\hline 14 & $11: 21$ & Talita: A imagem ali é distorcida. & \\
\hline 15 & $11: 23$ & Giovanna: Várias... & \\
\hline 16 & $11: 24$ & $\begin{array}{l}\text { Elio: Todos veriam o mesmo gato independente do } \\
\text { ângulo? Por exemplo, se ele emite miniaturas vai } \\
\text { ser igual para todos os lados. Então não daria } \\
\text { para ver o gato, olhar o rosto do gato, se eu não } \\
\text { estou aí. }\end{array}$ & $\begin{array}{c}\text { Elio } \\
\text { argumentando } \\
\text { que não veria } \\
\text { um lado do gato } \\
\text { se estivesse } \\
\text { posicionado em } \\
\text { seu oposto. }\end{array}$ \\
\hline 17 & $11: 39$ & $\begin{array}{l}\text { P: Tá! Por que ele estaria emanando em todas as } \\
\text { direções. }\end{array}$ & $\begin{array}{l}\text { Parece que a } \\
\text { professora não } \\
\text { previa a } \\
\text { resposta de Elio, } \\
\text { por não ter } \\
\text { explorado sua } \\
\text { sugestão. }\end{array}$ \\
\hline 18 & $11: 42$ & Elio: Como uma onda, né? & \\
\hline 19 & $11: 46$ & $\begin{array}{l}\text { Carla: Mas e tipo... se por acaso vai vim, vêm } \\
\text { voando um monte de miniatura, porque eu vejo } \\
\text { uma coisa e ele vê diferente? Se são iguais? }\end{array}$ & $\begin{array}{l}\text { Carla colocando } \\
\text { visão } \\
\text { complementar a } \\
\text { questão de Elio. }\end{array}$ \\
\hline 20 & $11: 59$ & $\begin{array}{l}\text { P: O que mais? Ó! Imagina que eu estou aqui } \\
\text { olhando para todos vocês. Todos vocês tão } \\
\text { emanando miniaturinhas. }\end{array}$ & $\begin{array}{l}\text { Alunos } \\
\text { demonstram } \\
\text { curiosidade e } \\
\text { interesse. }\end{array}$ \\
\hline
\end{tabular}




\begin{tabular}{|c|c|l|c|}
\hline 21 & $12: 10$ & Giovanna: Imagina a mistura que ia dar isso! & \\
\hline 22 & $12: 13$ & $\begin{array}{l}\text { Alunos: Ia ser uma confusão... Muitas } \\
\text { informações... }\end{array}$ & \\
\hline 23 & $12: 21$ & $\begin{array}{l}\text { P: Isso... Vocês acham que isso ia ser algum } \\
\text { problema? }\end{array}$ & \\
\hline 24 & $12: 23$ & Jade: Ah! Deve dar... Com certeza! & $\begin{array}{c}\text { Enfase no } \\
\text { caráter } \\
\text { Paterial" das } \\
\text { eidola. }\end{array}$ \\
\hline 25 & $12: 27$ & $\begin{array}{l}\text { Lembrando que para o Leucipo, como ele era } \\
\text { Vamos imaginar, assim, uma coisa sólida. }\end{array}$ & $\begin{array}{l}\text { Tarik: Nossa! Já pensou o tanto de miniaturas } \\
\text { se batendo? }\end{array}$ \\
\hline 26 & $12: 41$ & P: As miniaturas iriam se bater. \\
\hline 27 & $12: 45$ & Talita: Também ia furar o olho! & $\begin{array}{c}\text { Faz gesto com o } \\
\text { dedo em direção } \\
\text { ao olho. }\end{array}$ \\
\hline 29 & $12: 46$ & $\begin{array}{l}\text { Aluno: Nossa! Na hora que trombasse no olho! } \\
\text { (risadas) }\end{array}$ & \\
\hline 30 & $12: 53$ & Aluna: Lógico! Se é matéria ia furar o olho! & \\
\hline
\end{tabular}

Entre os turnos 20 a 30 nota-se a professora atuando de modo a contribuir para os alunos perceberem o problema decorrente de se conceber as eidola como algo material. De fato, assumimos aqui uma simplificação ao nível de escolaridade enfocado, conforme discutimos na seção 4.1, tratando as eidola como se fossem corpúsculos materiais, mas, dada a opção adotada, os alunos posicionaram-se adequadamente, compreendendo os problemas das miniaturas serem algo material e chocarem-se no espaço. Pode ser que essa transposição didática interna tenha favorecido uma visão relativista, embora tenha apontado adequadamente para o fato de que as explicações para os fenômenos apresentavam limitações. Implicitamente, ela vai preparando os alunos para perceberem que a observação dos fenômenos não levará a uma interpretação consensual, aspecto que era um dos nossos objetivos selecionados para tratarmos sobre a natureza da ciência.

Depois disso, a professora apresenta outras limitações da teoria de Leucipo e, a seguir, apresenta a teoria de Empédocles: 
10/9/2007 - Aulas 3 e 4 - Arquivo I

\begin{tabular}{|c|c|c|c|}
\hline Turno & Tempo & Falas & Observações \\
\hline 31 & $12: 57$ & $\begin{array}{l}\text { P: Gente, e lembrando que se os átomos se } \\
\text { combinavam na hora em que eles se chocavam, imagina } \\
\text { a Gisele vindo, se chocando com a Jade ali. Então quais } \\
\text { eram os problemas da teoria do Leucipo? Como as } \\
\text { eidolas, eidolas eram as miniaturas, passam umas } \\
\text { pela outras sem sofrerem interferência? Então } \\
\text { imagine eu aqui recebendo as miniaturas de todos } \\
\text { vocês. Chega tudo bem, não se choca. Né? Ou seja, } \\
\text { como que a gente consegue enxergar vários objetos ao } \\
\text { mesmo tempo? Quantas eidolas não estavam chegando } \\
\text { nos olhos da gente! Tá? Só que era um fato que a luz, } \\
\text { ela se cruza. Certo? E, no entanto, a gente consegue } \\
\text { observar os objetos e esse cruzamento de luz não } \\
\text { interfere na hora que a gente vê os objetos. Então } \\
\text { usando a explicação da eidola, isso daria uma confusão } \\
\text { aqui no meio e, no entanto, a gente sabe que isso não } \\
\text { acontece. Certo? Bom! Então como que a imagem... } \\
\text { quais eram os outros problemas ainda? Se eu estou... } \\
\text { Uma montanha, por exemplo, que é enorme. Se eu } \\
\text { estou distante, eu enxergo a montanha pequenininha. } \\
\text { Mas se eu chegar perto da montanha, a montanha fica } \\
\text { grande. Como é que fica essa história da eidola? Então } \\
\text { ela emite eidolas de vários tamanhos? Por que se eu } \\
\text { estou longe eu enxergo a montanha pequena, se eu } \\
\text { estou perto eu enxergo a montanha grande. E por que os } \\
\text { objetos, se a gente estiver distante, eles acabam } \\
\text { parecendo, assim, menores? Tá? Então esses eram } \\
\text { problemas assim da teoria do Leucipo. }\end{array}$ & $\begin{array}{c}\text { Risos. } \\
\text { Os alunos } \\
\text { divertem-se ao } \\
\text { imaginar a } \\
\text { situação. } \\
\text { Professora } \\
\text { aponta o } \\
\text { problema da } \\
\text { interação dos } \\
\text { átomos. } \\
\text { Problema do } \\
\text { tamanho da } \\
\text { montanha e de } \\
\text { outros objetos } \\
\text { variando com a } \\
\text { distância. }\end{array}$ \\
\hline 32 & $14: 52$ & $\begin{array}{l}\text { P: Bom! Vamos ver agora a teoria de um outro agora, } \\
\text { que é do Empédocles. O Empédocles, que tá aqui... } 493 \\
\text { a } 430 \text { a.C. Ele dizia o seguinte. Que tudo que existe é } \\
\text { formado pelos quatro elementos: ar, água, terra e fogo. } \\
\text { E o que era a luz para o Empédocles? Para o Epicuro } \\
\text { (ela queria dizer Leucipo) era alguma coisa que entrava } \\
\text { no olho, para o Empédocles, não. Para o Empédocles } \\
\text { era o seguinte. A luz vinha do elemento fogo, } \\
\text { lembrando que para eles eram os quatro elementos: } \\
\text { terra, ar, fogo e água. Então a luz vinha do elemento } \\
\text { fogo. E nós enxergamos os objetos, porque sai alguma } \\
\text { coisa do meu olho, tipo tentáculos, ou o que ele chamou } \\
\text { de raio visual. Então sai do meu olho, vai lá bate na } \\
\text { Gisele e traz a Gisele para dentro do meu olho. Com se } \\
\text { fosse, gente, o tato. Para gente sentir se uma coisa é } \\
\text { mole, dura, se está quente, se está fria, a gente não } \\
\text { precisa pôr a mão? (Alunos fazem gesto afirmativo com } \\
\text { a cabeça). Então para enxergar, para o Empédocles, } \\
\text { tinha que sair alguma coisa do meu olho e tipo, }\end{array}$ & $\begin{array}{l}\text { No texto da } \\
\text { professora, } \\
\text { apresentamos } \\
\text { aspectos da } \\
\text { teoria de } \\
\text { Epicuro e ela } \\
\text { deve ter se } \\
\text { confundido. }\end{array}$ \\
\hline
\end{tabular}




\begin{tabular}{|c|c|c|c|}
\hline & & $\begin{array}{l}\text { apalpava os materiais e trazia a imagem dos materiais } \\
\text { para dentro do meu olho. }\end{array}$ & \\
\hline 33 & $16: 26$ & $\begin{array}{l}\text { Alunos: Que coisa, né? Desculpa! (a aluna se desculpa } \\
\text { porque seu comentário interrompeu a professora). }\end{array}$ & $\begin{array}{l}\text { A classe faz } \\
\text { silêncio. }\end{array}$ \\
\hline 34 & $16: 32$ & $\begin{array}{l}\text { P: Gente, qual é o problema dessa teoria? Quem } \\
\text { consegue enxergar? }\end{array}$ & \\
\hline 35 & $16: 37$ & $\begin{array}{l}\text { Ivana: Se eu for observar algo muito longe, até esse } \\
\text { negócio que sai do olho chegar lá para apalpar, por } \\
\text { exemplo, se eu vou enxergar o Sol. Até ele chegar lá, } \\
\text { apalpar e trazer já vai estar de noite.. }\end{array}$ & $\begin{array}{l}\text { Risos dos } \\
\text { alunos. }\end{array}$ \\
\hline 36 & $16: 54$ & P: Tá! Então objetos muito distantes...Né? ...fala. & \\
\hline 37 & $16: 59$ & $\begin{array}{l}\text { Elio: Se fosse assim, então não ia existir ilusão de } \\
\text { ótica. Se ele realmente pudesse sair do olho e sentir } \\
\text { como se fosse o tato, não iríamos enxergar coisas que } \\
\text { não existem. Sair do olho é bem complicado, né? } \\
\text { Mãozinhas assim (faz um gesto que explicativo) indo lá } \\
\text { longe e voltando é meio estranho. E o choque entre } \\
\text { esses tentáculos olhando para mesma coisa? }\end{array}$ & \\
\hline 38 & $17: 22$ & P: Alguém enxerga mais algum problema? & \\
\hline 39 & $17: 24$ & Aluno: Não... Eu não enxergo...(risos) & $\begin{array}{c}\text { Comentário } \\
\text { bem humorado } \\
\text { do aluno. } \\
\end{array}$ \\
\hline 40 & $17: 31$ & $\begin{array}{l}\text { P: Bom! Aí vem ó... Se é alguma coisa que sai do olho } \\
\text { da gente, então depende do observador. Certo? Então a } \\
\text { gente poderia ver no escuro! Não é? Por que é alguma } \\
\text { coisa que está dependendo dos meus olhos somente. } \\
\text { Então esse seria também um outro furo, né? Então todo } \\
\text { mundo ia conseguir enxergar no escuro. }\end{array}$ & \\
\hline
\end{tabular}

Tanto na apresentação da teoria de Empédocles, como na discussão de suas limitações, não percebemos elementos específicos que possam ter fomentado o relativismo. Nota-se entre os turnos 33- 40 que os alunos apresentaram bons argumentos para criticar a explicação do fogo visual, demonstrando envolvimento com o tema. A observação do vídeo mostra uma interação descontraída e comprometida entre os elementos da relação didática, ou seja, pareceu-nos que os alunos estavam engajados na compreensão do conteúdo. Nesse sentido, parece-nos que a apresentação do tema utilizando os slides e propondo questionamentos contribuíram para promover a apropriação da problemática pelos alunos, conforme pretendíamos (seção 3.2.7).

Depois disso, a professora apresentou a explicação de Aristóteles para a luz e a visão, seguindo a mesma estratégia: apresentando sua concepção de mundo e as explicações coerentes com ela. Ao final, antes de os alunos lerem o texto 2 
(Apêndice C.2), a professora questionou a sala sobre os aspectos da natureza da ciência pretendidos para esse episódio:

\begin{tabular}{|c|c|c|c|}
\hline \multicolumn{4}{|c|}{ 10/9/2007 - Aulas 3 e 4 - Arquivo I } \\
\hline Turno & Tempo & Falas & Observações \\
\hline 44 & $25: 13$ & $\begin{array}{l}\text { P: Aí vem uma pergunta que eu quero que vocês } \\
\text { respondam agora. Será que a natureza, observar os } \\
\text { fenômenos, fornece informações que permitem uma } \\
\text { única informação? Ou seja, todos vocês observando um } \\
\text { mesmo fenômeno natural, esse fenômeno, só na } \\
\text { observação, fornece as informações suficientes para } \\
\text { que todos vocês cheguem na mesma explicação? O que } \\
\text { você acham? }\end{array}$ & \\
\hline 45 & $25: 45$ & Alunos: Não... & \\
\hline 46 & $25: 47$ & P: Por quê? & \\
\hline 47 & $25: 48$ & $\begin{array}{l}\text { Elio: Cada um tem uma lógica de raciocínio. De acordo } \\
\text { com o que ele retira do meio, ele vai utilizar o que ele } \\
\text { já conhece para conseguir, depois, criar a sua teoria. } \\
\text { Isso quer dizer que ela não vai ficar igual a de } \\
\text { ninguém. Seria bem engraçado se eu colocasse algo } \\
\text { idêntico ao da prova do Yuri, por exemplo. Pensamos } \\
\text { igualzinho? }\end{array}$ & Relativismo? \\
\hline 48 & 26:08 & $\begin{array}{l}\text { P: Por isso que é legal prova dissertativa, né? Ninguém } \\
\text { vai responder igualzinho. E como é que... E pelo que } \\
\text { vocês já viram até agora, que eu só acabei mostrando } \\
\text { três teorias. Como é que fica a ciência? Falando de um } \\
\text { modo geral: Física, Química, Biologia. Como é que } \\
\text { vocês acham que a ciência se desenvolve? }\end{array}$ & \\
\hline 49 & $26: 34$ & $\begin{array}{l}\text { Erika: Pelas diferentes opiniões? Diferentes pontos de } \\
\text { vista? }\end{array}$ & Relativismo? \\
\hline 50 & $26: 40$ & $\begin{array}{l}\text { P: O que mais? Então ao longo da história cada um vai } \\
\text { dando a sua... }\end{array}$ & \\
\hline 51 & $26: 46$ & Erika: Opinião sobre os diferentes (inaudivel). & $\begin{array}{l}\text { Ela parece } \\
\text { dizer a } \\
\text { palavra } \\
\text { temas. }\end{array}$ \\
\hline 52 & $26: 49$ & $\begin{array}{l}\text { Elio: Bom! Naqueles... No início era tudo atribuído aos } \\
\text { deuses ou os dogmas. As pessoas se desprendem dos } \\
\text { dogmas e começam a ver o mundo com mais razão. } \\
\text { Procuram respostas para obter. Ou seja, pessoas que } \\
\text { desafiam o conhecimento. }\end{array}$ & \\
\hline 53 & $27: 13$ & P: Alguém quer fazer mais algum comentário? & \\
\hline 54 & $27: 20$ & $\begin{array}{l}\text { Tarik: Tipo assim professora, muitas vezes o que você } \\
\text { pensa influencia... a tecnologia influencia, porque ela } \\
\text { pode me ajudar a ver mais a fundo. Essas coisas da luz, }\end{array}$ & $\begin{array}{l}\text { Concepção } \\
\text { prévia de } \\
\text { que a ciência }\end{array}$ \\
\hline
\end{tabular}




\begin{tabular}{|c|c|c|c|}
\hline & & $\begin{array}{l}\text { tipo e tal, eu posso ver mais a fundo com a tecnologia } \\
\text { que, tipo, eu tenho hoje do que a de antigamente. } \\
\text { Antigamente era mais... pode ver aí que algumas } \\
\text { teorias eram meio absurdas. Assim é uma coisa que eu } \\
\text { acho que hoje em dia ninguém teria uma teoria dessa. } \\
\text { Acho que a tecnologia influencia nisso daí também. }\end{array}$ & $\begin{array}{l}\text { atual } \\
\text { resolveria } \\
\text { todos os } \\
\text { problemas. } \\
\text { OS5 }\end{array}$ \\
\hline 55 & $27: 53$ & $\begin{array}{l}\text { P: Então as teorias evoluem com o tempo. É isso? } \\
\text { Alguém tem mais algum comentário? }\end{array}$ & \\
\hline 56 & 28:02 & $\begin{array}{l}\text { Elio: De acordo com a teoria anterior você procura os } \\
\text { defeitos daquela teoria e vai formando a sua teoria a } \\
\text { partir dos descobrimentos da anterior. Por isso quanto } \\
\text { mais passa o tempo, como o Tarik falou, a teoria vai } \\
\text { ficando mais próxima. Por exemplo, essas teorias são } \\
\text { de } 400 \text { a.C. algumas para gente hoje parecem loucura, } \\
\text { mas para época era algo inovador. }\end{array}$ & \\
\hline 57 & $28: 25$ & $\begin{array}{l}\text { P: E vocês conseguem enxergar que no fundo, parar } \\
\text { para pensar na teoria que está lá, muitas vezes a gente } \\
\text { enxerga coisas que quem elaborou não está } \\
\text { enxergando. Então no fundo a divergência de idéias } \\
\text { acaba fazendo com que a ciência vá evoluindo. Porque } \\
\text { você imagina se todo mundo concordasse com o } \\
\text { Leucipo, por exemplo. Não é verdade? Então a } \\
\text { divergência de idéias é que acaba fazendo com que } \\
\text { uma teoria vá evoluindo. Tá? }\end{array}$ & \\
\hline 58 & 29:02 & $\begin{array}{l}\text { P: Então agora vocês vão ler um texto que tem a ver... } \\
\text { E no final do texto têm umas questões que vocês vão } \\
\text { colocar numa folha separada para entregar para gente. }\end{array}$ & $\begin{array}{l}\text { De 29:14 até } \\
\text { 58:00 } \\
\text { acontece a } \\
\text { leitura e } \\
\text { discussão do } \\
\text { texto. }\end{array}$ \\
\hline
\end{tabular}

Antes de os alunos lerem o texto 2, que sistematiza essas discussões apresentadas, a professora colocou a questão: "Será que a natureza, observar os fenômenos, fornece informações que permitem uma única informação?”. Podemos verificar indícios de uma posição relativista na resposta dos aluno Elio (turno 47) e a manifestação de que as diferentes interpretações eram opiniões (turno 49). Tais posicionamentos sinalizam a visão encontrada posteriormente nas respostas escritas, das quais apresentamos uma amostra no início desta análise. Embora apenas três alunos tenham se posicionado de modo marcante durante a discussão, pode-se observar no vídeo que a maioria dos estudantes permaneceu acompanhando e endossando a troca de idéias. Não foi possível encontrar nenhum indício de que alguém discordasse das respostas dos colegas.

De fato, defender a idéia de que a observação da natureza não permite uma única hipótese segura, pode levar a um relativismo. Nosso quadro teórico havia sinalizado tal 
obstáculo. Por isso, nossa preocupação no primeiro episódio histórico foi enfatizar que as explicações formuladas pelos filósofos não eram meras opiniões pessoais, mas estavam fundamentadas por concepções de mundo de diferentes escolas de pensamento. $\mathrm{O}$ modo como cada um interpretava os fenômenos era influenciado por seus referentes teóricos. Entretanto, ao invés de tal concepção, manifestou-se mais claramente, na maioria das respostas dos alunos, uma visão relativista.

Permeando a visão de que naquela época seria normal cada filósofo ter sua opinião pessoal sobre um fenômeno, surgiu o obstáculo estrutural OC5 já previsto por nós(seção 4.1), com relação à sobrevalorizar a capacidade da ciência atual em resolver todos os problemas (turno 54), enfatizando também o papel da tecnologia. Imaginar que a ciência atual tenha mais recursos pareceu implicar em aceitar que seria normal eles formularem hipóteses absurdas em épocas passadas. Nossa expectativa naquele momento era de que os próximos episódios poderiam mostrar, pelo menos, que mesmo com recursos tecnológicos, ainda não é possível haver uma única interpretação para os fenômenos. Mais do que isso, pretendíamos defender que os pressupostos teóricos do observador influenciam na sua interpretação.

Com base nos dados analisados, parece-nos mais plausível que a visão relativista tenha surgido da confluência entre essas concepções prévias e o novo conteúdo abordado. Algumas dessas concepções havíamos previsto como obstáculos estruturais a serem enfrentados ou contornados, já discutidos anteriormente. Os alunos tomaram conhecimento de que a tentativa de explicar a luz e a visão cerca de 25 séculos atrás resultou em diferentes interpretações para os fenômenos, ocasionando diferentes explicações. Suas respostas na discussão com a professora e no material escrito recolhido trazem a visão de que, naquela época, estudiosos não dispunham de conhecimentos e nem de recursos tecnológicos adequados, e isso justificaria as diferentes explicações. Parecenos estar implícito nessa visão que isso não tem nada a ver com a ciência atual.

Antes de os alunos lerem o texto 2, que sistematizava o conteúdo do episódio I, eles já manifestavam indícios de uma concepção relativista. Pode ser que a atuação da professora na transposição didática interna a tenha favorecido, mas não é possível identificar até que ponto essa idéia seria parte de concepções prévias dos alunos, e tampouco se isso seria claro para eles antes de terem contato com o conteúdo. 
Admitindo que os alunos tivessem uma concepção relativista antes da aula, o texto 2 (Apêndice C.2) não foi suficiente para modificar essa visão. Há um parágrafo que sintetiza a idéia central do texto:

Parece que apenas observar o comportamento da natureza $e$ pensar racionalmente sobre os fenômenos propiciou o surgimento de diferentes explicações. Entretanto, os filósofos elaboravam teorias que estavam relacionadas a essas observações, ou seja, não era apenas questão de opinião pessoal. A observação da natureza era um ato fundamental para tentar explicar os fenômenos naturais. Mas será que era suficiente? O importante é compreender que construir essas explicações não é um processo simples, nem óbvio. É claro que o modo de os gregos pensarem sobre os fenômenos naturais é muito diferente do modo como os cientistas fazem atualmente. Mas, olhar para alguns episódios da história da ciência nos faz perceber quão complexo é o processo da produção do conhecimento sobre a natureza. (Texto 2 piloto para os alunos, Apêndice C.2).

Embora os alunos tivessem recebido o texto com o negrito acima destacado, a visão de que as distintas explicações são diferentes opiniões pessoais ainda surgiu em algumas respostas.

O retorno dado pelos alunos trouxe alguns argumentos que não havíamos previsto (turnos 17, 20, 31, 35, 37) abordando detalhes que não tinham sido discutidos nas reuniões de preparação com a professora. Desse modo, aspectos que poderiam ter promovido discussões importantes para o contexto, não puderam ser aproveitadas (turnos 17 ao 21 e turnos 31 a 37). Essas lacunas que detectamos ao longo da análise apontam para aspectos que precisam ser considerados tanto em replicações do curso, como na elaboração de novas propostas. Houve ainda a manifestação de obstáculos estruturais que havíamos previsto, entretanto, parece que a concepção prévia da tecnologia atual poder solucionar os problemas do passado, não foi suficientemente tratado durante a preparação da professora. Claro que com duas horas-aula e um único texto nossa expectativa era de apenas poder levantar a questão e envolver os alunos com a problemática, a ser aprofundada nos próximos episódios. 
A possível posição relativista identificada nesse momento inicial do curso não representaria problemas para nossos objetivos educacionais, desde que, com os outros conteúdos a serem estudados, os alunos pudessem perceber não existir observação neutra de fenômenos, independentemente da época tratada. Além disso, esperávamos sua compreensão de que isso não significa ser cada teoria decorrente de opiniões pessoais.

$\mathrm{Na}$ análise desses dados, não foi possível perceber dificuldades dos alunos em entender o contexto do episódio I, no nível bastante simplificado que julgamos possível abordar, quando elaboramos o Saber a Ensinar. Parece-nos ter sido a abordagem bastante adequada, pois motivou os alunos a interagir na discussão e a apresentar argumentos muito interessantes para os problemas suscitados pelas teorias estudadas, como por exemplo nos turnos 17, 20, 31, 35, 37.

Seja mais em função de concepções prévias ou seja decorrente da interação na relação didática, a análise dos dados nos sugere que o episódio I desempenhou importante papel na proposta. Ele foi capaz de engajar os alunos no tema do curso, provocar certa inquietude com relação ao conteúdo sobre a natureza da ciência e sobre as próprias explicações possíveis para a luz. Acreditamos que o episódio 1 trouxe à tona uma concepção relativista, que caberia à continuidade do curso problematizar.

Esses resultados, a análise dos dados e das reflexões advindas do acompanhamento do curso permitiram que efetuássemos algumas modificações no texto 2 do curso piloto. Essa nova versão, aprimorada para os textos dos alunos durante a realização dessa pesquisa, aparece no Apêndice B.2, sob o título de "curso proposto". Os parágrafos apresentados no início e no final dessa análise foram modificados para:

Havia diferentes teorias para tentar explicar a luz e a visão nesse período. De modo geral, eram combinações das características: os homens enxergavam porque algo saía dos olhos, ou porque algo entrava nos olhos; havia ainda os que diziam que a luz não era algo material, mas uma modificação na matéria que havia entre o objeto e os olhos. Cada teoria estava associada à visão de mundo de uma escola de pensamento, ou seja, não era uma interpretação individual de cada filósofo, como se fosse uma opinião pessoal. Pelo contrário, os filósofos não constituíam unidades isoladas, eles eram representantes de escolas que estavam competindo. Todos estavam pensando sobre os mesmos 
fenômenos ópticos, buscavam entendê-los utilizando raciocínios lógicos, porém, cada escola de pensamento fornecia uma explicação para a luz e a visão. Será que há algo de estranho nisso? Por que não havia um consenso?

Parece que apenas observar o comportamento da natureza $e$ pensar racionalmente sobre os fenômenos propiciou o surgimento de diferentes explicações. Entretanto, os filósofos elaboravam teorias que estavam relacionadas a essas observações, ou seja, não era apenas questão de opinião pessoal. A observação da natureza era um ato fundamental para tentar explicar os fenômenos naturais. Mas será que era suficiente? O importante é compreender que construir essas explicações não é um processo simples, nem óbvio. É claro que o modo de os gregos pensarem sobre os fenômenos naturais é muito diferente do modo como os cientistas fazem atualmente. Mas, olhar para alguns episódios da história da ciência nos faz perceber quão complexo é o processo da produção do conhecimento sobre a natureza. (Texto 2 proposto, Apêndice B.2, grifos no original).

\subsubsection{Evento Éter}

O tema histórico de que partimos para tratar a natureza da ciência foi a disputa entre as teorias ondulatória e corpuscular para representar a luz no início do século XIX. O papel do éter luminífero foi central nesta disputa, sendo um dos conteúdos que consideramos adequado aos objetivos dos curso proposto (seção 3.2.3). Um dos problemas enfrentados na elaboração da seqüência de atividades sobre este tema foi a falta de prérequisitos dos alunos para abordar a sua complexidade conceitual. Isso justificou em parte a inserção dos dois episódios anteriores (Gregos e Século XVII). Durante a elaboração das atividades e das estratégias pedagógicas para abordar este tema, alguns obstáculos estruturais discutidos no capítulo 3 tornaram-se realidade. Entre eles, ficou clara a "existência de conteúdos da história da ciência que não são de fácil compreensão para uma pessoa da atualidade" (OS9, seção 4.1). De fato, a opção por abordar esse ente inobservável foi considerada como um dos riscos assumidos na proposta desenvolvida.

O éter instigou a imaginação dos estudantes, mas, por ser polêmico, foi de difícil compreensão. Os alunos alternavam momentos de questionamento e rejeição à concepção 
de uma matéria indetectável, com outros em que essa concepção não motivava nenhuma discussão. Por um lado, o éter de Huygens foi enfaticamente questionado durante a atividade do debate, tomando a maior parte do tempo a ela destinado; por outro lado, o "meio transparente de Aristóteles que tinha a qualidade da transparência e permitia a visão" não motivou nenhuma polêmica. Percebemos, em outros momentos do curso, a relutância dos alunos em aceitar a existência de "uma matéria que não se pode sentir, nem ver, nem provar que existe".

Nosso pressuposto na criação do curso era de que entender a utilidade do éter luminífero na teoria ondulatória da luz poderia problematizar uma concepção puramente empirista de ciência. A primeira hipótese levantada para analisar essa questão foi investigar se - e em que medida - nossas estratégias haviam fracassado em modificar tal concepção, dificultando a compreensão de um ente inobservável.

Havíamos assumido o risco de inserir conteúdos complexos para o nível de escolaridade enfocado, pressupondo que certas estratégias pedagógicas permitiriam superar ou contornar os obstáculos previstos. A impossibilidade de compreensão dos entes inobserváveis acarretaria restrições aos nossos pressupostos, sugerindo a inadequação desse conteúdo aos propósitos pedagógicos visados. A despeito dos argumentos de ordem teórica a sustentarem a inclusão desse tópico histórico, pelo valor que agregaria à abordagem dos aspectos da natureza da ciência selecionados, a dimensão empírica da aplicação poderia apontar uma restrição ao nível de escolaridade enfocado, ou ainda, falhas na elaboração das estratégias pedagógicas ou no desenvolvimento do material didático. Entretanto, a análise dos dados trouxe uma outra perspectiva.

Dessa forma, consideramos que entender o papel desempenhado pelo éter no curso piloto constitui-se em um evento merecedor de ser analisado em detalhes. Buscamos investigar, no Evento Éter, como se desenvolveu o processo de interação entre os sujeitos e esse objeto de conhecimento (CARVALHO; GONÇALVES, 2000, p. 73), ou seja, a interação entre os elementos da relação didática. Por tratar-se de um processo desencadeado ao longo do curso, não foi possível eleger apenas um momento e estabelecer um único recorte de aula. Assim, selecionamos algumas sequiências de aulas, de dias diferentes, em busca da resposta para o problema em questão (CARVALHO; GONÇALVES, 2000, p. 73). Enfocamos algumas situações de interação entre os sujeitos e o saber, buscando contemplar um ciclo capaz de responder à questão: os processos de interação entre alunos, professora e o 
conceito de éter promoveu, ou não, a compreensão do papel que um ente inobservável pode desempenhar nas explicações científicas? Essa questão permitiu-nos compreender se tal processo contribuiu para criticar uma visão puramente empírica da ciência, ou ainda, se permitiu abordar os aspectos da natureza da ciência pretendidos.

As fontes de dados utilizadas na análise foram (i) transcrição das gravações em vídeo mostrando a relação didática; (ii) extratos de anotações de campo de diferentes dias; (iii) excertos do Saber a Ensinar e, (iv) respostas escritas pelos alunos na avaliação final.

O primeiro contato que os alunos tiveram com a idéia de um inobservável foi no episódio I, quando se apresentou a impossibilidade do vazio para Aristóteles, e a existência de uma matéria sutil que preencheria todo o universo, a quintessência ou o éter. Utilizando os slides "gregos" (Apêndice C), a professora explicou aspectos da teoria de Aristóteles e apresentou brevemente sua concepção de Universo, enfatizando sua recusa pelo vazio e a idéia do éter preenchendo as regiões celestes. Vejamos algumas falas (Anexo A):

\begin{tabular}{|c|c|c|c|}
\hline \multicolumn{4}{|c|}{ 10/9/2007 - Aulas 3 e 4 - Arquivo I } \\
\hline Turno & Tempo & Falas & Observações \\
\hline 42 & $20: 59$ & $\begin{array}{l}\text { P: [...]. E eu preciso de um meio transparente para } \\
\text { poder enxergar as estrelas. [...] E esse meio } \\
\text { transparente seria a quintessência ou o éter. } \\
\text { Então o Aristóteles ele foi, vamos dizer assim, um } \\
\text { dos que defendeu essa idéia aqui da existência } \\
\text { do éter. Então, não existia espaço vazio. O éter } \\
\text { acabava preenchendo tudo, da Lua para cima. [...]. } \\
\text { Ele colocou cada planeta aqui, numa esfera, numa } \\
\text { camada de éter. [...] Lembram do Shrek? } \\
\text { Camadas de cebola? (alunos fazem gesto e } \\
\text { afirmação com a cabeça e sorriem) Então, aqui } \\
\text { seriam camadas de éter. }\end{array}$ & $\begin{array}{c}\text { Professora } \\
\text { apresenta o éter } \\
\text { sugerindo uma } \\
\text { "solução" para } \\
\text { impossibilidade } \\
\text { do vazio. } \\
\text { Professora } \\
\text { utiliza analogia } \\
\text { com as camadas } \\
\text { de cebola. }\end{array}$ \\
\hline
\end{tabular}

Ao finalizar a apresentação do conteúdo do episódio I, ela levantou questões para os alunos, e, durante essa discussão, não houve nenhuma manifestação sobre o éter, nenhum questionamento. A seguir, os alunos leram o texto 2, que sistematizava o conteúdo do episódio I, e responderam às questões. Neste texto havia um breve comentário sobre o éter:

Aristóteles não aceitava a idéia de vazio. Todo o Universo seria ocupado por matéria. As regiões celestes seriam preenchidas pela quintessência, ou o éter, e, aqui na Terra, os espaços entre os objetos 
seriam preenchidos pelo ar. (Veja texto 2 para os alunos no Apêndice C.2).

Ao final desse texto, havia cinco questões, e uma delas era: "Qual teoria você acha que explicava melhor a luz naquela época? Justifique”. A ampla maioria da sala respondeu que era a teoria de Aristóteles e, nesse momento, não houve qualquer comentário mencionando ou questionando o que seria o éter. Talvez a luz como qualidade da transparência de Aristóteles tenha parecido "menos bizarra" que os tentáculos de Empédocles ou as eidola de Leucipo. Entretanto, a idéia de um meio indetectável não passou incólume em momentos posteriores do curso.

No episódio II, o éter foi retomado, primeiramente, durante a apresentação da teoria de Huygens (veja slides no Apêndice C.5.). As explicações da professora (na íntegra no Anexo A, transcrição da aula 11.9.07) vão reforçando a idéia da existência de um meio material em que a luz se propaga. Vejamos a seguir alguns trechos de sua fala.

\begin{tabular}{|c|c|c|c|}
\hline \multicolumn{4}{|c|}{ 11/9/2007 - Aulas 5 e 6 - Arquivo I } \\
\hline Turno & Tempo & Falas & Observações \\
\hline 25 & $20: 38$ & $\begin{array}{l}\text { P: [...] para Huygens, luz era uma forma de } \\
\text { movimento da matéria, tá? E aqui ta um trecho } \\
\text { daquele tratado que ele escreveu. Então, considera- } \\
\text { se certo que a visão é excitada pela impressão de } \\
\text { algum movimento de matéria, que age sobre os } \\
\text { nervos no fundo dos nossos olhos, e essa é ainda } \\
\text { outra razão para se ter como um movimento de } \\
\text { matéria que se encontra entre nós e os corpos } \\
\text { luminosos. }\end{array}$ & $\begin{array}{l}\text { Optamos por } \\
\text { brevíssimo } \\
\text { trecho de fonte } \\
\text { primária } \\
\text { explicada em } \\
\text { seu contexto. }\end{array}$ \\
\hline 32 & $23: 17$ & $\begin{array}{l}\text { P: }[\ldots] \text { Então, olha, cada ponto luminoso possui } \\
\text { um movimento muito rápido que provoca ondas } \\
\text { no éter. }[\ldots]\end{array}$ & \\
\hline 33 & $23: 24$ & $\begin{array}{l}\text { P: [...] Então, o Huygens, ele acreditava, ele } \\
\text { defendia a idéia do éter, tá? }\end{array}$ & \\
\hline 34 & $23: 44$ & $\begin{array}{l}\text { P: Lembrando que o éter foi citado ontem, lá na } \\
\text { aula do... dos gregos com Aristóteles, né... que o } \\
\text { Aristóteles dizia que eu preciso de um meio } \\
\text { transparente entre o observador e o objeto, e aí ele } \\
\text { deu o nome de éter. Aqui, o Huygens, ele também } \\
\text { hã... não... a explicação dele é diferente, mas ele } \\
\text { também se utiliza da idéia do éter pra essas } \\
\text { ondas conseguirem se propagar aqui. Tá? }\end{array}$ & $\begin{array}{l}\text { Poderíamos ter } \\
\text { explorado mais } \\
\text { as diferenças, } \\
\text { em função dos } \\
\text { diferentes } \\
\text { contextos. }\end{array}$ \\
\hline 52 & $28: 48$ & $\begin{array}{l}\text { Elio: }[\ldots] \text { voltando lá ao Aristóteles. O que que era } \\
\text { pra ele pra que houvesse... pra que se pudesse }\end{array}$ & $\begin{array}{l}\text { Aluno retoma a } \\
\text { idéia do meio }\end{array}$ \\
\hline
\end{tabular}




\begin{tabular}{|l|l|l|c|}
\hline & & $\begin{array}{l}\text { enxergar? Que o meio permitisse. Um meio } \\
\text { transparente. Porém, se há uma parede, não há } \\
\text { transparência entre a luz e meus olhos pra luz... o } \\
\text { som não, ele não depende do meio... }\end{array}$ & $\begin{array}{c}\text { permitindo } a \\
\text { visão. }\end{array}$ \\
& & $\begin{array}{l}\text { P: Então você ta me dizendo que, no caso, depende } \\
\text { do meio? } \\
\text { Elio: Isso. E a luz continua sendo uma onda. } \\
\text { P: Tá, quem mais? }\end{array}$ & \\
\hline 53 & $29: 21$ & $\begin{array}{l}\text { Pedro: Naquela época pode falar do vácuo? } \\
\text { Agora? }\end{array}$ & \\
\hline
\end{tabular}

Nesse momento, nem o curso pretendia polemizar o éter, nem os alunos o questionaram. Depois de toda a discussão em torno da teoria de Huygens, da teoria de Newton, e do fenômeno das cores, a maior preocupação externada pelos alunos era com relação à natureza da luz. No turno 52 acima, por exemplo, o aluno Elio fez referência ao meio, inclusive retomando a concepção aristotélica, mas ele o utilizou apenas para defender uma concepção ondulatória para a luz. O interessante foi ele tentar derrubar o argumento apresentado de que a luz deveria contornar obstáculos, se fosse uma onda. Ele parece ter defendido a hipótese de que "o som contorna os obstáculos por ser uma onda no ar, mas a luz é um movimento em outro tipo de matéria, não se pode esperar que ela se comporte igual ao som". Para o aluno Elio o éter não representava um problema. O aluno Pedro, que fala logo a seguir, pergunta sobre a aceitação do vácuo, e não questiona o éter nem a colocação do colega. $\mathrm{O}$ assunto que continuava polêmico voltava-se à natureza da luz. Vejamos alguns exemplos:

11/9/2007 - Aulas 5 e 6 - Arquivo I

\begin{tabular}{|c|c|l|c|}
\hline Turno & Tempo & \multicolumn{1}{|c|}{ Falas } & Observações \\
\hline 47 & $27: 57$ & $\begin{array}{l}\text { Pedro: Professora, esse negócio tá me } \\
\text { confundindo, heim! (risos da classe) Uma hora eu } \\
\text { acredito que a luz é uma onda, outra hora eu } \\
\text { acho que luz é um corpo. No final a gente vai } \\
\text { chegar a uma conclusão do que que é a luz? }\end{array}$ & $\begin{array}{c}\text { Aluno manifesta } \\
\text { desconforto, } \\
\text { embora em tom } \\
\text { bem humorado. }\end{array}$ \\
\hline 59 & $36: 17$ & $\begin{array}{l}\text { Tarik: É assim, professora...é... como que... é... Se } \\
\text { a luz é partícula, se uma incide na outra, por } \\
\text { que que não influencia na trajetória da outra? } \\
\text { Se uma ta é sendo projetada, assim e a outra ... por } \\
\text { que que uma não interfere na outra? }\end{array}$ & $\begin{array}{c}\text { A idéia da } \\
\text { materialidade da } \\
\text { luzomoda os } \\
\text { alunos. }\end{array}$ \\
\hline 61 & $37: 45$ & $\begin{array}{l}\text { Elaine: Professora, a luz seria uma coisa... faz } \\
\text { gesto com a mão) matéria...? }\end{array}$ & \\
\hline
\end{tabular}




\begin{tabular}{|c|c|c|c|}
\hline 78 & $48: 33$ & $\begin{array}{l}\text { P: [...] mas aí vem uma pergunta pra vocês: será } \\
\text { que só olhando o experimento, a experiência, dá } \\
\text { pra você concluir tudo sobre como aquele } \\
\text { fenômeno acontece? Só de você montar a } \\
\text { experiência e ficar observando? } \\
\text { Alguns alunos: Não... } \\
\text { Pedro: Precisa ter a tese matemática... }\end{array}$ & $\begin{array}{c}\text { Professora faz } \\
\text { pergunta sobre } \\
\text { aspecto da } \\
\text { natureza da } \\
\text { ciência. } \\
\text { Alunos } \\
\text { demonstram } \\
\text { segurança na } \\
\text { resposta. }\end{array}$ \\
\hline
\end{tabular}

Percebemos que os alunos ainda não estavam questionando a materialidade ou a natureza do éter. Sua atenção ainda se voltava para a natureza da luz. Na fala dos alunos nos turnos 47 e 59 nota-se certo desconforto com a dúvida de a luz ser algo material ou uma onda. Outros comentários desses e de outros alunos ao longo da aula confirmam essa mesma preocupação.

Outro aspecto relevante é que os alunos buscavam entender o que é a luz, e não o que era a luz. Suas falas e reações indicam inquietação, sugerindo que não havia a perspectiva histórica. Era como se as teorias do século XVII devessem ser capazes de explicar "definitivamente" o que é a luz. O que torna essa manifestação dos alunos ainda mais instigante é o fato de eles terem estudado no bimestre anterior ao curso, a luz como onda eletromagnética. Nas reuniões realizadas com a professora durante a preparação do curso, procuramos saber dos pré-requisitos dominados pelos alunos vinculados ao tema a ser desenvolvido, e, nessa ocasião, ela relatou que eles haviam estudado a luz como onda eletromagnética. No entanto, suas atitudes, questionamentos e desconforto sugerem que essa informação não os impediu de se envolverem intensamente com o conteúdo do curso. Eles estavam tentando entender os argumentos para concluir “o que é a luz”.

Enquanto os alunos acompanhavam detalhes do episódio, como o papel do éter na concepção ondulatória da luz, o desenrolar do experimento com o prisma, os argumentos favoráveis e contrários a ambas as teorias, o pano de fundo dessa discussão era a natureza da ciência. Veja, por exemplo, no turno 78 reproduzido acima, quando a professora problematiza a questão da observação neutra de experimentos e a resposta dos alunos. Eles vivenciaram a dificuldade na compreensão dos limites de cada teoria; assim, quando a professora perguntou sobre a possibilidade de observações conclusivas, eles demonstraram segurança em negá-la. Entretanto, nada indicava, até aquele momento, um questionamento sobre a existência do éter. 
Depois da apresentação do conteúdo do episódio II, os alunos leram o texto 4 (Apêndice C.2) e responderam às questões. O éter passa a ter um pouco mais de destaque nesse texto, embora implicitamente, permeando toda a explicação da teoria de Huygens. Ele é mencionado brevemente em outra passagem do texto:

Outros filósofos naturais de sua época [de Huygens] também apresentavam a luz como um tipo de onda no éter. (Texto 4, Apêndice C.2).

Pretendíamos mostrar aos alunos que o éter não era um problema para os filósofos da época; a divergência de idéias era com relação à natureza da luz.

No dia seguinte, a professora fez a correção das questões do texto 4 com toda a sala, apresentou novamente as regras do debate que ocorreria na aula seguinte, leu e discutiu os textos 5 e 6 junto com os alunos e fez a sistematização do episódio (textos no Apêndice C.2). O texto 5 apresenta a teoria de Huygens e, embora não haja longa discussão sobre o éter, ele permeia toda explicação da luz como ondas. Buscamos colocar também não ser o éter uma idéia utilizada apenas por Huygens, ainda que em uma pequena menção:

A idéia da luz como a propagação de um pulso no éter não foi adotada apenas por Huygens, mas ele tornou-se seu defensor mais conhecido. (Texto 5, Apêndice C.2).

O texto 6 trata da teoria corpuscular e não faz nenhuma crítica ao éter. Em uma das citações de Newton, o meio fluido é mencionado, mostrando que a crítica era com relação à luz como onda, e não com relação ao meio fluido:

Pois pressão ou movimento não podem ser propagados em um fluido em linhas retas além de um obstáculo que intercepta parte do movimento, mas se curvarão e se espalharão em todas as direções no meio quiescente que está além do obstáculo. (NEWTON, 1996, p. 265). (Texto 6, Apêndice C.2).

Newton não questionou a existência do fluido, no caso o éter: ele criticou a concepção ondulatória para a luz, pois ela parecia contrária ao que se observava. $\mathrm{O}$ fato de 
argumentar como uma onda deveria se comportar num meio fluido significa admitir a existência desse fluido.

Esse era o momento previsto no curso para iniciar uma ênfase com relação ao éter. Entretanto, durante a maior parte da aula, a questão mais marcante na fala dos alunos continuava sendo com relação à materialidade da luz e a possibilidade de "provas" na ciência (veja transcrição da aula 12.9.07 no Anexo A). As aulas 7 e 8 do curso foram destinadas à correção das questões e à sistematização do conteúdo do episódio II, buscando também preparar os alunos para o debate.

Nessas discussões os alunos não questionaram o éter. Depois de uma aluna perguntar sobre a materialidade da luz, a professora aproveitou a explicação para retomar a teoria ondulatória, enfatizando o papel do éter e tentando instigar os alunos a se manifestarem.

\begin{tabular}{|c|c|c|c|}
\hline \multicolumn{4}{|c|}{ 12/9/2007 - Aulas 7 e 8 - Arquivo II } \\
\hline Turno & Tempo & Falas & Observações \\
\hline 147 & $49: 47$ & $\begin{array}{l}\text { P: Agora a teoria da ondulatória, diz [..] que } \\
\text { entre o Sol e a Terra tem o éter, que seria } \\
\text { uma matéria invisível como o ar, muito } \\
\text { leve, muito sutil... a luz seria como uma } \\
\text { onda, que vai caminhando no éter, até } \\
\text { chegar aos nossos olhos. Mas precisa ter o } \\
\text { éter, porque se não tiver o éter como é que } \\
\text { a luz vai caminhar? A luz precisa de um } \\
\text { meio e esse meio é o éter. Porque se a onda } \\
\text { não tiver o meio, ela não caminha... Meio } \\
\text { que forçosamente, quem defende a } \\
\text { ondulatória, defende a existência do éter. } \\
{[\ldots]}\end{array}$ & $\begin{array}{c}\text { Poucos alunos } \\
\text { acompanham essa } \\
\text { troca de idéias. } \\
\text { Alguns alunos que } \\
\text { participam do } \\
\text { debate estão atentos. } \\
\text { Aos poucos mais } \\
\text { alunos começam a } \\
\text { prestar a atenção }\end{array}$ \\
\hline 148 & $51: 18$ & $\begin{array}{l}\text { P: [...] a gente acabou falando da idéia do } \\
\text { éter, e quem vai defender a teoria } \\
\text { ondulatória... as ondas, elas precisam de um } \\
\text { meio para caminhar. Lembra daquela figura } \\
\text { da perturbação de uma gota na superfície de } \\
\text { água? Que a gota cai e forma aquelas ondas? } \\
\text { É, a visão que o Huygens tinha é que aquela } \\
\text { perturbação que se forma na superfície é a luz } \\
\text { que vai chegando nos nossos olhos, só que o } \\
\text { meio seria o éter. Então é preciso de um } \\
\text { meio material... quer dizer, a luz não é } \\
\text { matéria, é uma perturbação que caminha } \\
\text { no meio material. Esse meio material seria } \\
\text { o éter. [...] }\end{array}$ & $\begin{array}{l}\text { Agora todos os } \\
\text { alunos visíveis nas } \\
\text { imagens estão } \\
\text { prestando atenção. }\end{array}$ \\
\hline
\end{tabular}


A professora enfatizou a utilidade do éter na teoria ondulatória, afirmando tratar-se de uma matéria, porém muito leve, muito sutil. Ela esclareceu que a luz não era matéria, mas sim uma perturbação que caminhava nessa matéria sutil, o éter. Os alunos acompanhavam a explicação, mas não questionavam a natureza do éter. Essas informações não motivaram discussões naquele momento, mas surgiriam de maneira contundente em momentos posteriores do curso. A professora insistiu na tentativa de levantar essa questão:

\begin{tabular}{|c|c|c|c|}
\hline \multicolumn{4}{|c|}{ 12/9/2007 - Aulas 7 e 8 - Arquivo III } \\
\hline Turno & Tempo & Falas & Observações \\
\hline 156 & $02: 11$ & $\begin{array}{l}\text { P: }[\ldots] \text { O éter é antigo, hein, gente, foi o } \\
\text { Aristóteles, hein. O Aristóteles falava que era um } \\
\text { meio... e foi ele que levantou a polêmica do éter lá } \\
\text { em } \mathbf{4 0 0 , 3 0 0} \text { antes de Cristo. Então a trajetória } \\
\text { do éter vem caminhando aí. A minha outra } \\
\text { pergunta é a seguinte: Os atomistas, eles defendiam } \\
\text { que o espaço era totalmente vazio, [...] num lugar, } \\
\text { [...], como numa cápsula de vidro, você conseguisse } \\
\text { sugar o ar de lá de dentro e deixar o vazio completo } \\
\text { lá. Ou seja, o nada. A primeira pergunta: vocês } \\
\text { acham que isso é possível? Eu sugo o ar de lá e lá é } \\
\text { o vazio absoluto. Lá não tem mais nada...? Sim ou } \\
\text { não? }\end{array}$ & $\begin{array}{l}\text { Professora } \\
\text { retoma a idéia } \\
\text { de éter em } \\
\text { Aristóteles. }\end{array}$ \\
\hline 157 & 03:13 & Alunos: Não... & $\begin{array}{c}\text { Alunos } \\
\text { comentam } \\
\text { questão } \\
\text { levantada. }\end{array}$ \\
\hline 158 & $03: 14$ & P: Por quê? & \\
\hline 159 & $03: 15$ & Alunos confabulam. Inaudivel. & \\
\hline 160 & $03: 17$ & $\begin{array}{l}\text { P: O que que vocês acham que fica lá dentro?... } \\
\text { Alunas: O éter. } \\
\text { P: Então vocês estão apostando na idéia do éter? } \\
\text { Daniele: Não, como você pode provar que o éter } \\
\text { existe? }\end{array}$ & $\begin{array}{l}\text { Daniele discute } \\
\text { amigavelmente } \\
\text { com os colegas } \\
\text { ao redor, } \\
\text { buscando } \\
\text { criticar a teoria } \\
\text { ondulatória. }\end{array}$ \\
\hline 161 & $03: 30$ & $\begin{array}{l}\text { Comentários inaudiveis entre Alunas Daniele, Erika } \\
\text { e Gisele. } \\
\text { Alunas riem e aluno Daniel faz comentário } \\
\text { inaudível, parece questionar o vácuo. } \\
\text { Daniel, Erika e Gisele defendem a teoria } \\
\text { ondulatória e Daniele argumenta criticando-a. O } \\
\text { clima é descontraído e amigável. }\end{array}$ & $\begin{array}{l}\text { Parece que já há } \\
\text { uma separação } \\
\text { entre quem } \\
\text { defenderáa } \\
\text { corpuscular e } \\
\text { quem defenderá } \\
\text { a ondulatória. }\end{array}$ \\
\hline
\end{tabular}


Como as respostas foram bem humoradas, e os alunos estavam se preparando para o debate entre as teorias, possivelmente as alunas estivessem se colocando na perspectiva do século XVII, ao afirmarem que o éter ocuparia os espaços supostamente vazios. Esse momento foi a primeira vez no curso em que foi possível perceber um questionamento sobre a existência do éter. A aluna Daniele, além de questionar a professora sobre a possibilidade de provar a existência do éter, participou do grupo do teatro, bem como do grupo do debate em defesa da teoria corpuscular. Ela e um pequeno grupo ao redor estavam discutindo sobre as teorias, e pareceu-nos ser esse argumento usado mais como estratégia para criticar a teoria ondulatória do que um questionamento sobre a possibilidade de provas. Os alunos continuaram polemizando sob pontos de vista diferentes, e a professora reapresentou a questão buscando organizar a discussão.

\begin{tabular}{|c|c|c|c|}
\hline \multicolumn{4}{|c|}{ 12/9/2007 - Aulas 7 e 8 - Arquivo III } \\
\hline Turno & Tempo & Falas & Observações \\
\hline 162 & 03:59 & $\begin{array}{l}\text { P: }[\ldots] \text { : Imagine isso, uma cápsula de vidro, onde } \\
\text { eu suguei o que tinha lá, com uma bomba de } \\
\text { vácuo, certo? Então o som, o som ele não vai se } \\
\text { propagar dentro da cápsula, porque o som precisa } \\
\text { do ar para se propagar, [...]. Mas a gente não } \\
\text { consegue ver através dessa cápsula de vidro? }\end{array}$ & \\
\hline 163 & $04: 37$ & Alunos: Sim! & \\
\hline 164 & 04:38 & $\begin{array}{l}\text { P: E segundo a teoria ondulatória, a luz precisa } \\
\text { de um meio para caminhar, que seria... (alunos: } \\
\text { o éter.) } \\
\text { P: Então eu queria a explicação: pensando na } \\
\text { corpuscular e pensando na ondulatória, como é } \\
\text { que eu consigo ver as paredes da cápsula, se lá } \\
\text { dentro não tem mais nada? }\end{array}$ & \\
\hline 165 & 05:00 & Vários falam ao mesmo tempo. & $\begin{array}{c}\text { Alguns } \\
\text { parecem } \\
\text { responder } \\
\text { sobre o éter. }\end{array}$ \\
\hline 166 & $05: 06$ & $\begin{array}{l}\text { P: Porque o som não vai se propagar, eu tirei o ar } \\
\text { (ruídos). Mas eu continuo enxergando as paredes } \\
\text { da cápsula de vidro lá dentro... Qual teoria que } \\
\text { explica melhor isso? A corpuscular ou a } \\
\text { ondulatória? } \\
\text { Aluno: A ondulatória. } \\
\text { Poucos alunos respondem. }\end{array}$ & \\
\hline
\end{tabular}


Os alunos não se envolveram muito com a problemática e, logo a seguir, a professora organizou os grupos para o debate.

$\mathrm{Na}$ aula seguinte, ocorreu o debate entre o grupo que defendia a teoria corpuscular e o outro, na defesa da ondulatória (Apêndice C.1). Foi nessa atividade que o questionamento e o desconforto dos alunos com relação ao éter manifestou-se de forma intensa. As discussões sobre a natureza do éter, por vezes tensas, acaloradas ou um tanto hostis, tomaram mais da metade do tempo requerido pela atividade. Dentre as seqüências selecionadas, a atividade do debate foi o momento em que os conflitos cognitivos dos alunos ficaram mais evidentes.

A leitura dos dados gravados do debate confirmou a impressão registrada nas anotações de campo daquele dia: ${ }^{21}$ destacava-se a insistência dos alunos em questionar a existência do éter, e a cobrança de uma explicação mais clara sobre sua natureza. Em seus contatos com esse conteúdo até então, não havia se manifestado o tipo de pergunta que surgiu no debate. Não esperávamos um posicionamento tão inquisidor.

Vejamos alguns momentos do debate.

Conforme previsto, cada equipe apresentou inicialmente sua teoria, para depois apontar os problemas da teoria rival. O grupo da corpuscular utilizou menos da metade do tempo permitido para a exposição, e uma das alunas já o inicia com uma crítica indireta ao éter.

Para facilitar a leitura, inserimos ao lado dos nomes dos alunos o símbolo (O) para aqueles que pertencem ao grupo da ondulatória, e o símbolo (C) para aqueles que pertencem ao grupo da corpuscular.

\begin{tabular}{|c|c|l|c|}
\hline \multicolumn{4}{|c|}{ 13/9/2007 - Aulas 9 e 10 -Arquivo I } \\
\hline Turno & Tempo & \multicolumn{1}{|c|}{ Falas } & Observações \\
\hline 16 & $06: 30$ & $\begin{array}{l}\text { Carla (C): Acho que... assim, uma das principais, } \\
\text { seria que, assim, ele realmente provou. Ele não } \\
\text { supôs a existência de nada pra tá falando sobre a luz. } \\
\text { Ele colocou no papel e falou, ele mostrou que } \\
\text { realmente tem como. Ele não supôs a existência de } \\
\text { nada pra aquilo ocorrer, pra aquilo tá ocorrendo. É } \\
\text { um do principais pontos, assim... }\end{array}$ & $\begin{array}{c}\text { grupo } \\
\text { confabulam. }\end{array}$ \\
\hline
\end{tabular}

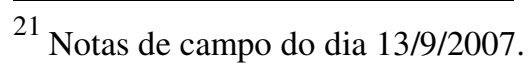


A estratégia utilizada pela aluna foi insinuar a fragilidade de uma teoria construída sobre uma suposição "fantasiosa", no caso, a existência de um éter: "Ele [Newton] não supôs a existência de nada pra aquilo ocorrer". Ela busca defender que Newton teria provado a teoria corpuscular, mas não apresenta argumentação para isso. Diante da rápida exposição e dos poucos argumentos para defender a teoria corpuscular, a professora pergunta se eles gostariam de apresentar alguma crítica à teoria ondulatória. Esperávamos que eles fossem enfatizar as limitações dessa teoria no século XVII, mencionando os exemplos voltados aos fenômenos ópticos trabalhados nos textos e nas explicações da professora. Entretanto, a primeira crítica volta-se à sutil materialidade do éter:

\begin{tabular}{|c|c|l|l|}
\hline \multicolumn{3}{|c|}{$13 / 9 / 2007$ - Aulas 9 e 10 - Arquivo I } & Observações \\
\hline Turno & Tempo & \multicolumn{1}{|c|}{ Falas } & \multicolumn{1}{|c|}{} \\
\hline 19 & $07: 36$ & $\begin{array}{l}\text { Tarik (C): É... a gente não aceita a teoria } \\
\text { ondulatória por vários motivos. Assim, é... na teoria } \\
\text { ondulatória, eles dizem assim que é o movimento } \\
\text { que ocorria numa matéria muito sutil. [... } \\
\text { Daniele (C): ...matéria sutil? } \\
\text { Carla (C): Ou é matéria ou não é. } \\
\text { Tarik (C): Ou é matéria ou não é. } \\
\text { Carla(C): A gente não entende como... ou a gente } \\
\text { não aceita o fato de falar que matéria sutil é uma } \\
\text { coisa que não dá pra ver. Se é matéria é matéria. } \\
\text { Tarik(C): Se é matéria, não importa... é sutil mas é } \\
\text { matéria do mesmo jeito. }\end{array}$ \\
\hline
\end{tabular}

Percebemos que o desconforto dos alunos com relação ao éter estava vinculado à impossibilidade de percebê-lo ou detectá-lo. Esse questionamento repetiu-se várias vezes ao longo do debate, tornando, por vezes, o clima tenso entre os alunos. Na aula anterior, a professora havia explicado sobre o éter e motivado várias vezes os alunos a se manifestarem, como mostramos acima em alguns exemplos. Apenas no final da aula, a aluna Daniele perguntou para a professora se ela poderia provar a existência do éter (turno $\mathrm{X}$ ), mas num contexto de conversas informais entre o pequeno grupo que debatia sobre as teorias da luz. Parecia mais uma estratégia de retórica do que uma dúvida que requeria uma resposta.

Durante a exposição da teoria ondulatória, o aluno Elio tentou responder a esse questionamento: 


\begin{tabular}{|c|c|c|c|}
\hline \multicolumn{4}{|c|}{ 13/9/2007 - Aulas 9 e 10 - Arquivo I } \\
\hline Turno & Tempo & Falas & Observações \\
\hline 26 & $13: 27$ & $\begin{array}{l}\text { Elio (O): Bom, o éter é aquilo que eles falaram que } \\
\text { era uma suposição. Até onde sabemos, ninguém } \\
\text { prova se existe ou não o éter. Pode ser uma } \\
\text { suposição, sim, mas da mesma forma que você } \\
\text { não prova que existe, você também não prova } \\
\text { que não existe. O que acontece? É... ele seria uma } \\
\text { espécie de ar, porém, bem leve, [...] Aí... todos } \\
\text { sabemos que, até o século XVII, muito já se fez pela } \\
\text { Ciência, porém, algumas incógnitas ficam. O éter } \\
\text { responde muitas dessas incógnitas. [...] }\end{array}$ & $\begin{array}{c}\text { Aluno } \\
\text { questiona a } \\
\text { necessidade } \\
\text { da "prova", } \\
\text { porém } \\
\text { sinalizando a } \\
\text { noção da } \\
\text { utilidade do } \\
\text { éter. }\end{array}$ \\
\hline
\end{tabular}

O aluno Elio tentou rebater a crítica, utilizando o mesmo argumento de seus opositores: "[...] da mesma forma que você não prova que existe, você também não prova que não existe". Além disso, ele buscou relembrar a utilidade da existência desse éter para a ciência. Entretanto, o outro grupo continuou questionando o éter, sempre criticando a impossibilidade de provar sua existência. $\mathrm{O}$ aluno Elio tentou responder às críticas:

\begin{tabular}{|c|c|c|c|}
\hline \multicolumn{4}{|c|}{ 13/9/2007 - Aulas 9 e 10 - Arquivo I } \\
\hline Turno & Tempo & Falas & Observações \\
\hline 39 & 19:53 & $\begin{array}{l}\text { Tarik (C): [...]. Se a explicação da luz veio do éter, } \\
\text { que o Elio mesmo disse que não sabe se existe, } \\
\text { como que ele pode basear uma teoria se ele não } \\
\text { sabe. O que que é o éter? O que que é o éter, qual } \\
\text { a finalidade do éter e alguém pode me provar } \\
\text { que esse éter existe? }\end{array}$ & \\
\hline 44 & $21: 32$ & $\begin{array}{l}\text { Elio (O): Sobre o éter. Do mesmo jeito, a Carla fez } \\
\text { uma suposição, que os corpos se juntam no ar, a luz } \\
\text { andando junto com o ar. Ah, então não tem ar no } \\
\text { escuro? Ou não tem luz onde não tem ar? Espera } \\
\text { aí, vocês dizem sobre o vácuo, já que não acreditam } \\
\text { no éter. Então, como que a luz da estrela chega até } \\
\text { a Terra? }\end{array}$ & $\begin{array}{l}\text { Elio parece } \\
\text { desmontar } \\
\text { grupo da } \\
\text { corpuscular, } \\
\text { apesar da } \\
\quad \text { idéia } \\
\text { equivocada. }\end{array}$ \\
\hline
\end{tabular}

Nesse momento percebe-se uma modificação nas expressões dos alunos do grupo corpuscular. Até então, eles demonstravam confiança e entusiasmo enquanto questionavam o éter, mas depois dessa fala do Elio, parece surgir certo receio em suas fisionomias. Ele valeu-se do argumento utilizado pela Carla para responder à crítica da concepção corpuscular da luz, de que as partículas de luz e as partículas do ar poderiam "ocupar o mesmo lugar no espaço". 
O debate continuou focado no éter. Os alunos do grupo opositor e os jurados continuavam pressionando o grupo da ondulatória, que tentava argumentar. Esse grupo não tinha recebido informações suficientes para lidar com algumas questões não previstas, e surgidas durante os debates.. Desse modo, ou surpreenderam-nos algumas vezes com a criatividade e a capacidade de articulação de idéias, ou, por outras, percebeu-se que se atrapalharam com os conceitos. Para exemplificar, vamos reproduzir uma seqüência dessas discussões, sem interrupção, buscando mostrar o clima inquisidor desses questionamentos:

\begin{tabular}{|c|c|c|c|}
\hline \multicolumn{4}{|c|}{ 13/9/2007 - Aulas 9 e 10 - Arquivo I } \\
\hline Turno & Tempo & Falas & Observações \\
\hline 47 & $21: 48$ & $\begin{array}{l}\text { Elio (O): [..] se fala de éter desde a Idade } \\
\text { Antiga, os gregos já falavam do éter [...] O } \\
\text { éter, também, foi importante, ainda, né, pra } \\
\text { obra de Pitágoras. Pitágoras, que acreditava } \\
\text { no éter. É uma discussão sim polêmica, é. } \\
\text { Porém, como eu disse, você não vê o ar, você, } \\
\text { também provavelmente não vai poder sentir o } \\
\text { ar. [...] }\end{array}$ & $\begin{array}{l}\text { Comentário } \\
\text { inesperado sobre } \\
\text { Pitágoras. Não } \\
\text { há menção à ele } \\
\text { no material do } \\
\text { aluno }\end{array}$ \\
\hline 51 & $23: 20$ & Pedro do júri: Sim, mas o que é o éter? & $\begin{array}{l}\text { Alunos riem. } \\
\text { Apesar do clima } \\
\text { ser de bastante } \\
\text { comprometimento } \\
\text { e seriedade com } \\
\text { relação ao } \\
\text { assunto, os } \\
\text { alunos mostram } \\
\text { descontração e } \\
\text { bom humor. }\end{array}$ \\
\hline 52 & $23: 21$ & $\begin{array}{l}\text { Talita (O): O éter é uma matéria sutil e } \\
\text { imponderável. Que ele atravessa como se } \\
\text { fosse o vento, passando nos bosques, por } \\
\text { exemplo. Ele atravessa toda a matéria, então } \\
\text { ele não tem, acho que não tem... acho que } \\
\text { densidade... acho que é isso. }\end{array}$ & \\
\hline 53 & $23: 36$ & $\begin{array}{l}\text { Elio (O): O éter é considerado o quinto } \\
\text { elemento. Seria, bom, um exemplo bem } \\
\text { simples, imaginem como se fosse um ar bem } \\
\text { menos denso. Ele ocupa todos os espaços } \\
\text { vagos, porém ele não causa atrito. É uma } \\
\text { matéria... como eu poderia dizer (pausa) } \\
\text { teoricamente eu poderia dizer que ela seria } \\
\text { inútil. Não serve, além... } \\
\text { Elio }(\mathbf{O}) \text { : Ela tem, sim, a sua, sua utilidade, } \\
\text { correto? Porém a utilidade principal que eu } \\
\text { vejo é a propagação da luz. }\end{array}$ & \\
\hline
\end{tabular}




\begin{tabular}{|c|c|c|c|}
\hline 54 & $24: 18$ & $\begin{array}{l}\text { Elaine do júri: Mas você falou que pode } \\
\text { existir como não pode existir o éter. Então } \\
\text { você também não acredita que existe? }\end{array}$ & \\
\hline 55 & $24: 24$ & $\begin{array}{l}\text { Elio }(\mathbf{O}) \text { : Eu, particularmente, acredito no } \\
\text { éter. Eu não posso vir aqui e afirmar que o } \\
\text { éter existe porque eu vou estar corrompendo o } \\
\text { pensamento de vocês. }\end{array}$ & \\
\hline 56 & $24: 28$ & $\begin{array}{l}\text { Elaine do júri: E o que te leva a acreditar que } \\
\text { o éter existe? }\end{array}$ & \\
\hline 57 & $24: 29$ & $\begin{array}{l}\text { Elio (O): Eu não acredito em vácuo. Pensa no } \\
\text { nada, você consegue ver, imagina o nada! Vai } \\
\text { na sua cabeça o nada? }\end{array}$ & \\
\hline 58 & $24: 34$ & $\begin{array}{l}\text { Talita (O): um lugar totalmente sem nada... } \\
\text { Erika }(\mathbf{O}) \text { : um vácuo, sem nada... } \\
\text { Aluna na platéia faz comentário inaudível. }\end{array}$ & $\begin{array}{l}\text { Alguns alunos se } \\
\text { empolgame } \\
\text { alguns } \\
\text { comentários se } \\
\text { sobrepõem. }\end{array}$ \\
\hline 59 & $24: 38$ & Elio (O): breve comentário inaudivel & \\
\hline 60 & $24: 41$ & $\begin{array}{l}\text { Aluna do júri: Então é matéria, então é um } \\
\text { corpo. Um corpo... }\end{array}$ & \\
\hline 61 & $24: 46$ & $\begin{array}{l}\text { Elio (O): Um corpo... O éter, ele é } \\
\text { desprovido, ele é desprovido de matéria. } \\
\text { (Pedro do júri faz comentários inaudíveis) }\end{array}$ & $\begin{array}{l}\text { Alunos do grupo } \\
\text { da corpuscular } \\
\text { parecem } \\
\text { satisfeitos com a } \\
\text { pressão no grupo } \\
\text { rival. }\end{array}$ \\
\hline 62 & $24: 49$ & $\begin{array}{l}\text { Aluno do júri: Um lugar que não tem nada, } \\
\text { então você tem que inventar alguma coisa pra } \\
\text { colocar... }\end{array}$ & \\
\hline 63 & $24: 50$ & $\begin{array}{l}\text { Elio (O): Você pode provar que eu estou } \\
\text { inventando a existência do éter? Aristóteles } \\
\text { também... } \\
\text { (Falas sobrepostas inaudíveis) } \\
\text { (Enquanto a sala ri e troca idéias os alunos } \\
\text { do grupo da corpuscular demonstram } \\
\text { preocupação e trocam idéias) }\end{array}$ & $\begin{array}{l}\text { Elio reage um } \\
\text { tanto rudemente. } \\
\text { A sala ri } \\
\text { descontraída. } \\
\text { Risose } \\
\text { descontração na } \\
\text { classe. } \\
\text { Dispersão. }\end{array}$ \\
\hline 64 & $25: 14$ & $\begin{array}{l}\text { Elio (O): Você pode provar que ele não } \\
\text { existe? } \\
\text { (Falas sobrepostas: "Existe? Não existe? } \\
\text { Provar que existe...") }\end{array}$ & $\begin{array}{l}\text { Elio está sendo } \\
\text { pressionado pelo } \\
\text { júri. }\end{array}$ \\
\hline 65 & $25: 19$ & $\begin{array}{l}\text { Aluno do júri: Eu acho que você só pode } \\
\text { dizer alguma coisa a partir do momento que } \\
\text { você provar que ele existe. }\end{array}$ & $\begin{array}{l}\text { Alunos falam ao } \\
\text { mesmo tempo. }\end{array}$ \\
\hline 66 & $25: 24$ & $\begin{array}{l}\text { Elio (O): Quem sou eu pra provar que o éter } \\
\text { existe? Sou Deus? }\end{array}$ & \\
\hline
\end{tabular}




\begin{tabular}{|c|c|c|c|}
\hline 67 & $25: 27$ & $\begin{array}{l}\text { Jade do júri: O Elio, mas você tem que } \\
\text { provar que ele existe sim (inaudivel). }\end{array}$ & $\begin{array}{l}\text { O grupo da } \\
\text { ondulatória } \\
\text { demonstra } \\
\text { tensão. }\end{array}$ \\
\hline 68 & $25: 29$ & $\begin{array}{l}\text { Talita (O): Se nem os cientistas conseguem } \\
\text { provar que existe a gente vai conseguir } \\
\text { provar? } \\
\text { (Muitos alunos falam ao mesmo tempo. Grupo } \\
\text { da corpuscular fala e gesticula, mas falas } \\
\text { inaudiveis)) }\end{array}$ & $\begin{array}{l}\text { Apesar do riso e } \\
\text { da descontração } \\
\text { alunos } \\
\text { demonstram } \\
\text { desconforto com } \\
\text { o tema. }\end{array}$ \\
\hline 69 & $25: 42$ & $\begin{array}{l}\text { Aluno do júri: Nós não queremos que vocês } \\
\text { provem, nós queremos que vocês exponham } \\
\text { as idéias dos cientistas... } \\
\text { Pedro do júri: Inaudível as idéias Inaudível } \\
\text { achar uma matéria que não ... }\end{array}$ & $\begin{array}{l}\text { Alunos inquietos, } \\
\text { manifestações, } \\
\text { falas sobrepostas }\end{array}$ \\
\hline 70 & $25: 53$ & $\begin{array}{l}\text { Aluna do júri: } \mathrm{E} \text {, mas você tem que provar } \\
\text { que ele existe, se você está defendendo... } \\
\text { (falas sobrepostas) }\end{array}$ & \\
\hline 71 & $25: 55$ & $\begin{array}{l}\text { Elio (O): O que acontece... Quantos de vocês } \\
\text { acreditam em Deus? }\end{array}$ & $\begin{array}{l}\text { Alunos retrucam, } \\
\text { falas sobrepostas. } \\
\text { Inaudivel. }\end{array}$ \\
\hline 72 & 26:09 & $\begin{array}{l}\text { Carla (C): Agora ele está se metendo em } \\
\text { dogma da pessoa, cada um tem a sua religião. } \\
\text { Eu acho que o, que a gente tá discutindo } \\
\text { cientificamente sem cair nesses... } \\
\text { Pedro do júri: Eu acho que religião não vem } \\
\text { ao caso. } \\
\text { Carla (C): Isso não vem ao caso. }\end{array}$ & $\begin{array}{l}\text { Alunos inquietos, } \\
\text { clima tenso. }\end{array}$ \\
\hline 73 & $26: 12$ & Alunos falam ao mesmo tempo. & \\
\hline 74 & $26: 13$ & $\begin{array}{l}\text { Jade do júri: Você poderia pegar esses } \\
\text { cientistas que provavam... por exemplo, } \\
\text { Huygens, e provar, tipo, o que que ele dizia, o } \\
\text { que ele convencia as pessoas de dizer de } \\
\text { forma que o éter existe. Isso que a gente quer } \\
\text { que você fale. Não que você fale "eu não sou } \\
\text { Deus pra provar que ele existe"... lógico que } \\
\text { você não é, mas você está estudando sobre } \\
\text { essa teoria então você tem que explicar essa } \\
\text { teoria. }\end{array}$ & \\
\hline 75 & $26: 39$ & $\begin{array}{l}\text { Pedro do júri: Acho que assim, foi meio } \\
\text { estranho você falar de matéria sem } \\
\text { densidade, como pode ser uma matéria sem } \\
\text { densidade? } \\
\text { Elio (O): .. posso... } \\
\text { Pedro do júri: ....se não é matéria densa, o } \\
\text { que que é? }\end{array}$ & $\begin{array}{l}\text { Novos ruídos. } \\
\text { Falas dispersas. } \\
\text { Alunos falam ao } \\
\text { mesmo tempo. }\end{array}$ \\
\hline
\end{tabular}




\begin{tabular}{|c|c|c|c|}
\hline 76 & $26: 58$ & $\begin{array}{l}\text { Elio (O): Concorda que cada matéria tem } \\
\text { como propriedade uma densidade. O ar não é } \\
\text { tão denso quanto a água. Em falar nisso, } \\
\text { Newton acreditava que a luz se propagava } \\
\text { mais rápido na água do que no ar. Certo? É } \\
\text { fato também. Porém, eu não disse que o éter é } \\
\text { desprovido de matéria. Ele possui matéria, } \\
\text { sim. Eu disse que ele tem uma densidade } \\
\text { quase insignificante, correto? O que não } \\
\text { produz atrito. } \\
\text { Pedro do júri: Ahhh }\end{array}$ & $\begin{array}{l}\text { Parece que o } \\
\text { Pedro ficou } \\
\text { satisfeito com a } \\
\text { explicação. }\end{array}$ \\
\hline 77 & $27: 30$ & $\begin{array}{l}\text { Tarik (C): [...] Você disse que ela é matéria } \\
\text { também. Esse éter [...] esse éter é matéria } \\
\text { sutil, ainda é matéria. E... aqui tá dizendo que } \\
\text { a luz é o movimento desse éter, é o } \\
\text { movimento do éter. Então, como que a luz } \\
\text { não é uma matéria? }\end{array}$ & $\begin{array}{l}\text { Interessante } \\
\text { questão! Porém, } \\
\text { a professora } \\
\text { tinha explicado } \\
\text { anteriormente. }\end{array}$ \\
\hline 78 & 28:07 & $\begin{array}{l}\text { Elio (O): ó, o que acontece [...] o que é uma } \\
\text { onda? [...] é uma perturbação que se propaga } \\
\text { através do meio, correto? Esse meio que nós } \\
\text { entendemos é o éter. Porém, o éter não tem a } \\
\text { ver com a luz. Ele serve, sim, para se pro... } \\
\text { para que a luz se propague. Porém o éter não é } \\
\text { a luz, o éter sozinho... sem as ondas... não } \\
\text { gera luz. }\end{array}$ & $\begin{array}{l}\text { Parece que os } \\
\text { alunos ficaram } \\
\text { satisfeitos com a } \\
\text { explicação de } \\
\quad \text { Elio. }\end{array}$ \\
\hline 79 & 29:02 & $\begin{array}{l}\text { Erika (O): o que é vácuo? } \\
\text { (aluno Pedro do júri pergunta se existe vácuo, } \\
\text { outros alunos falam e a professora começa a } \\
\text { responder. Não é possivel compreender } \\
\text { porque ela responde uma pergunta que } \\
\text { parecia direcionada ao grupo da } \\
\text { corpuscular) }\end{array}$ & $\begin{array}{l}\text { Aluna dirige uma } \\
\text { pergunta ao } \\
\text { grupo da } \\
\text { corpuscular } \\
\text { tentando "viraro } \\
\text { jogo". }\end{array}$ \\
\hline 80 & $29: 46$ & $\begin{array}{l}\text { Tarik (C): Eu não vi nenhuma resposta } \\
\text { sendo, das minhas perguntas } \\
\text { respondidas... } \\
\text { Falas sobrepostas. Tarik pressiona sobre o } \\
\text { éter. }\end{array}$ & $\begin{array}{l}\text { Tarik volta a } \\
\text { pressionar o } \\
\text { grupo da } \\
\text { ondulatória. }\end{array}$ \\
\hline 81 & $30: 03$ & $\begin{array}{l}\text { Clarisse do júri: Como que você quer que } \\
\text { nós acreditamos da teoria do éter se nós não } \\
\text { sabemos o que seria o éter? } \\
\text { [...] }\end{array}$ & $\begin{array}{l}\text { Júri também } \\
\text { cobra } \\
\text { explicações. }\end{array}$ \\
\hline 82 & $30: 06$ & $\begin{array}{l}\text { Elio (O): }[\ldots] \text { o éter é sim constituído de } \\
\text { matéria, correto? Porém ele tem uma } \\
\text { densidade muito baixa, quase insignificante. } \\
\text { Correto? Não se sabe ao certo se éter existe. } \\
\text { Eu acredito, particularmente, eu acredito no } \\
\text { éter. Não acredito no nada, fica um pouco } \\
\text { difícil você imaginar "nada". Newton também } \\
\text { acreditava no éter. Porém, para Newton, o éter }\end{array}$ & $\begin{array}{l}\text { Elio pode ter } \\
\text { pesquisado sobre } \\
\text { o significado da } \\
\text { palavra éter e } \\
\text { sobre Pitágoras. } \\
\text { Informações não } \\
\text { foram dadas pelo }\end{array}$ \\
\hline
\end{tabular}




\begin{tabular}{|c|c|c|c|}
\hline & & $\begin{array}{l}\text { só existia no Universo, não... na atmosfera, } \\
\text { digamos assim, da Terra pra lá. Uma } \\
\text { explicação mais simples, correto? E que não } \\
\text { interferia na luz. Porém, Huygens acreditava } \\
\text { que o éter existia em todo o Universo, } \\
\text { preenchendo seus espaços vazios. Correto? O } \\
\text { éter, assim, éter na verdade significa o que } \\
\text { sempre se movimenta. Vem das palavras } \\
\text { gregas (?) sempre e (?) correr, ou seja, sempre } \\
\text { corre. Ele sempre tá em movimento, } \\
\text { movimento perpétuo. Não foi só Huygens e } \\
\text { Newton que acreditavam no éter, desde a } \\
\text { filosofia grega o éter já era comentado. } \\
\text { Aristóteles, Pitágoras, pessoas muito } \\
\text { importantes pra nossa época já } \\
\text { acreditavam na existência do éter. }\end{array}$ & $\begin{array}{c}\text { curso. } \\
\text { Grupo da } \\
\text { corpuscular } \\
\text { confabula. Suas } \\
\text { expressões } \\
\text { mudam de } \\
\text { segurança para } \\
\text { sutil } \\
\text { preocupação. } \\
\text { Indícios de } \\
\text { anacronismo, } \\
\text { mas não } \\
\text { esperávamos } \\
\text { evitá-lo. }\end{array}$ \\
\hline 83 & $31: 46$ & $\begin{array}{l}\text { Pedro do júri: Então o éter seria algo } \\
\text { material, extremamente... Seria matéria só que } \\
\text { extremamente não-densa? } \\
\text { Elio (O): Isso. (Falas sobrepostas). }\end{array}$ & $\begin{array}{l}\text { "Clima”sugere } \\
\text { que a explicação } \\
\text { de Elio teria sido } \\
\text { satisfatória. }\end{array}$ \\
\hline 84 & $31: 58$ & $\begin{array}{l}\text { Jade do júri: Como que eles descobriram a } \\
\text { existência desse éter? } \\
\text { Erika (O): Pra explicar o que eles não } \\
\text { puderam explicar. } \\
\text { [...] risos, comentários paralelos. }\end{array}$ & $\begin{array}{c}\text { Falas } \\
\text { sobrepostas }\end{array}$ \\
\hline 85 & $32: 11$ & $\begin{array}{l}\text { Elio (O): É... o que acontece... Se o éter } \\
\text { surgiu pra explicar o que nós, que } \\
\text { defendemos a teoria ondulatória, não pôde } \\
\text { explicar, por que Pitágoras já comentava } \\
\text { do éter? Ele já combinou com o Huygens que } \\
\text { nem existia, "eu vou falar do éter depois você } \\
\text { aproveita", ou, pelo contrário, Huygens se } \\
\text { baseou em algo que os gregos já diziam. } \\
\text { Então, espera aí, o éter não existe? Então o } \\
\text { Newton também errou. O que que acontece, } \\
\text { Newton falava do éter. O éter não existe? }\end{array}$ & $\begin{array}{c}\text { Como o outro } \\
\text { grupo se apoiava } \\
\text { no prestígio de } \\
\text { Newton, Elio } \\
\text { usou esse recurso } \\
\text { para "defender" } \\
\text { o éter. }\end{array}$ \\
\hline 86 & $32: 41$ & $\begin{array}{l}\text { Tarik (C): Você tava falando que Pitágoras } \\
\text { dizia que o éter existe, não é? Então, Pitágoras } \\
\text { também provou que o éter existe? Ou ele só } \\
\text { falou "o éter existe!"? Pitágoras disse: o éter } \\
\text { existe, passou a existir. Que haja o éter. }\end{array}$ & $\begin{array}{c}\text { Tarik parece } \\
\text { perceber a força } \\
\text { do argumento e } \\
\text { rapidamente } \\
\text { desvia a atenção } \\
\text { de todos para o } \\
\text { éter. }\end{array}$ \\
\hline 87 & $33: 04$ & $\begin{array}{l}\text { Daniele (C): Aí a partir daí, o Huygens falou } \\
\text { "opa, tem alguma coisa aí, o éter vai explicar } \\
\text { o que eu não posso explicar". }\end{array}$ & $\begin{array}{l}\text { A utilidade do } \\
\text { inobservável é de } \\
\text { difícil aceitação. }\end{array}$ \\
\hline 88 & 33:07 & $\begin{array}{l}\text { Talita (O): Eu tenho uma pergunta, por que } \\
\text { Newton acreditava no éter? } \\
\text { Aluna tenta novamente "inverter o jogo", mas }\end{array}$ & $\begin{array}{l}\text { Discussão } \\
\text { acalorada. } \\
\text { Parece que o }\end{array}$ \\
\hline
\end{tabular}




\begin{tabular}{|c|c|c|c|}
\hline & & $\begin{array}{l}\text { a pressão predomina sobre o grupo da } \\
\text { ondulatória. }\end{array}$ & $\begin{array}{l}\text { debate se } \\
\text { concentrava em: } \\
\text { existência do éter } \\
\text { X Newton. }\end{array}$ \\
\hline 91 & $33: 38$ & $\begin{array}{l}\text { Tarik (C): Os problemas que tinha na } \\
\text { corpuscular, ele jogava toda a culpa no éter? } \\
\text { Ele chegava assim "não, a culpa é do éter"? } \\
\text { Não... (falas sobrepostas) E outra coisa } \\
\text { também que eu gostaria que vocês } \\
\text { respondessem... } \\
\text { Elio (O): Posso só responder primeiro o que } \\
\text { vocês perguntaram? }\end{array}$ & $\begin{array}{c}\text { Polêmica. } \\
\text { Alunos } \\
\text { visivelmente } \\
\text { desconfortáveis } \\
\text { com relação ao } \\
\text { éter. }\end{array}$ \\
\hline 92 & $33: 44$ & $\begin{array}{l}\text { Tarik }(\mathbf{C}): \text { Não, porque se você não } \\
\text { respondeu até agora, você não vai conseguir } \\
\text { responder agora. }\end{array}$ & $\begin{array}{l}\text { Clima tenso, um } \\
\text { tanto hostil. }\end{array}$ \\
\hline 93 & $33: 48$ & $\begin{array}{l}\text { Elio (O): Eu não tenho certeza se o júri. } \\
\text { Vocês conseguiram entender alguma coisa } \\
\text { sobre o éter? }\end{array}$ & \\
\hline 94 & $33: 49$ & $\begin{array}{l}\text { Alguns alunos: Não! Mais ou menos... é } \\
\text { complicado... [...] } \\
\text { Elio: É complicado, o éter é complicado. }\end{array}$ & \\
\hline 97 & $33: 52$ & $\begin{array}{l}\text { Jade do júri: O que a gente não entendeu... } \\
\text { tudo bem, Pitágoras, o Pitágoras ele, né } \\
\text { descobriu lá o éter, assim como Huygens é né, } \\
\text { acreditou né, beleza... Então, eu queria saber } \\
\text { como que Pitágoras, então descobriu essa } \\
\text { existência do éter? }\end{array}$ & \\
\hline 98 & $34: 11$ & $\begin{array}{l}\text { Elio (O): Eu não posso falar que ele } \\
\text { descobriu. }\end{array}$ & \\
\hline 99 & $34: 12$ & $\begin{array}{l}\text { Jade do júri: Tá, então como que ele sabia } \\
\text { que existisse: o éter, então é, como ele disse, } \\
\text { haja o éter? } \\
\text { Elio (O): Não, é porque é assim... } \\
\text { Jade do júri: Ele inventou "ah! Éter!" Tá,... } \\
\text { um negócio passando aqui, pronto... "éter"! } \\
\text { (aluna gesticula enfaticamente). } \\
\text { Falas sobrepostas. }\end{array}$ & $\begin{array}{l}\text { Ruídos e } \\
\text { discussão } \\
\text { intensa. Aluna } \\
\text { Clarisse do júri } \\
\text { levanta a mão } \\
\text { para falar. } \\
\text { Continua clima } \\
\text { acalorado com } \\
\text { alunos falando ao } \\
\text { mesmo tempo. }\end{array}$ \\
\hline 101 & $34: 35$ & $\begin{array}{l}\text { Professora: Pessoal, ó... só um instantinho } \\
{[\ldots] \text { É,... as discussões tão indo bem, tal... [...] }} \\
\text { mas a gente também não pode esquecer que } \\
\text { essa polêmica que vem em cima do éter, que } \\
\text { vem desde lá do Aristóteles [...]. [...] mas o } \\
\text { próprio Newton tinha argumentos que ele } \\
\text { tirava o éter fora quando convinha e quando } \\
\text { não convinha ele colocava o éter pra explicar } \\
\text { os fenômenos. [...] vamos tentar desfocar um } \\
\text { pouco do éter e tentar voltar pra justificativa }\end{array}$ & \\
\hline
\end{tabular}




\begin{tabular}{|l|l|l|l|}
\hline & $\begin{array}{l}\text { da luz mesmo, como corpúsculo ou como } \\
\text { onda. [...] o júri tá só malhando o éter. [...] }\end{array}$ & \\
\hline
\end{tabular}

A professora interrompeu o debate, apontando que a polêmica estava se direcionando somente para o éter, e os grupos não discutiam as teorias, como cada uma explicava os fenômenos, etc. Ela colocou a questão do recipiente de vidro esvaziado pela bomba de vácuo e pediu que cada grupo explicasse como é possível enxergar lá dentro.

Depois das explicações, a professora encerrou o debate e pediu ao júri que se reunisse para dar o veredicto. Foi curioso, depois de tanta pressão sobre o grupo da ondulatória, o júri considerá-lo vencedor do debate, colocando inclusive que, embora a maioria deles acreditasse mais na corpuscular, os argumentos do grupo da ondulatória estavam melhores.

As primeiras impressões obtidas no contato com os dados do debate foram ambíguas. De um lado, a frustração pelo fato de os alunos terem utilizado argumentos inválidos $^{22}$ para o período, não terem mencionado sobre os fenômenos ópticos que cada teoria explicava melhor, e, no caso do grupo da corpuscular, terem utilizado como recurso, principalmente, o prestígio de Newton e o questionamento ao éter. Por outro lado, o engajamento na atividade, na criatividade em certas colocações e o uso da argumentação superou as expectativas. Com apenas quatro dias (8 aulas) de curso, eles elaboravam questões sobre um tema complexo, abordando aspectos tanto históricos quanto epistemológicos.

As anotações de campo do dia 13/9/2009 também apontam para essa preocupação com os argumentos inválidos para o período, e a satisfação com relação aos bons argumentos.

Foi pensando sobre essa seqüência de interações que surgiu uma nova perspectiva: os alunos não estavam apenas questionado a existência do éter e a necessidade de entendêlo para poder aceitar a teoria ondulatória, eles estavam vivenciando essas controvérsias. Mais do que discutir sobre duas teorias, eles experimentavam um pouco da dinâmica da ciência. Eles estavam conhecendo um exemplo de como é complexa a construção da

\footnotetext{
${ }^{22}$ Em trechos do debate que não reproduzimos aqui os alunos mencionam a diferença entre as propriedades das ondas mecânicas e das ondas eletromagnéticas; feixes de luzes coloridas que se cruzam no palco e experimentos de Young e Fresnel, que ocorreram no século XIX (Apêndice A).
} 
ciência. Ainda que provavelmente não tenham reproduzido as preocupações que os filósofos naturais tinham no final do século XVII, eles protagonizaram alguns aspectos dos debates na ciência, ou seja, atingiram vários de nossos propósitos pedagógicos. Não pretendíamos com o curso que os alunos simplesmente adquirissem conhecimentos históricos, mas que esses fossem utilizados como estratégia pedagógica para ensinar sobre a natureza da ciência. Nesse sentido, o éter foi o elemento a permitir que eles vivessem essa experiência, como sujeitos ativos no debate.

Nesse momento, compreendemos que, mais do que esperar a aceitação dos alunos , ou não, da existência de uma matéria indetectável, e entendessem sua utilidade, deveríamos utilizar esse questionamento para ressaltar aspectos da natureza da ciência. Já que pretendíamos questionar uma ciência puramente empírica, vivenciar a dificuldade em aceitar a existência de um ente inobservável, utilizado em muitas teorias ao longo da história, seria ótima oportunidade para atingir tal objetivo. Será que a continuidade do curso contribuiu para isso?

$\mathrm{Na}$ aula seguinte ao debate, os alunos tiveram novamente contato com o éter no teatro, cujo roteiro o enfatizava (Apêndice D 4.4). Cerca de dois terços dos diálogos do roteiro para o teatro voltam-se para explicar o éter e seu papel na ciência, buscando preparar o aluno para o conteúdo histórico-epistemológico do episódio III. No final da apresentação do teatro, a professora reuniu os alunos e perguntou sobre a atividade.

De um modo geral, os alunos participantes disseram que tinham entendido melhor o conteúdo do curso, as teorias e o éter, mas a aluna Adriana disse que o éter não ficou claro, mas corpúsculos e ondas foi o que ela mais entendeu.

Na aula seguinte ocorreu a apresentação em slides do episódio III, com uma revisão inicial dos fenômenos ópticos e apresentação do filme Dr. Quantum. A professora iniciou a explicação fazendo uma revisão do conteúdo trabalhado até então no curso, retomando o éter e destacando sua utilidade na história da ciência. Vejamos alguns exemplos:

\begin{tabular}{|c|c|l|c|}
\hline \multicolumn{4}{|c|}{ 17/9/2007 - Aulas 13 e 14 - Arquivo I } \\
\hline Turno & Tempo & \multicolumn{1}{|c|}{ Falas } & Observações \\
\hline 7 & $11: 25$ & $\begin{array}{l}\text { P: E os gregos, nós frisamos também por causa } \\
\text { daquela teoria do Aristóteles, que na verdade ele } \\
\text { não foi o primeiro que falou no éter, tá? Lá na } \\
\text { faixa, tem uma figura de uma deusa indiana muito }\end{array}$ & $\begin{array}{c}\text { Professora } \\
\text { enfatiza a } \\
\text { aceitação de } \\
\text { entes }\end{array}$ \\
\hline
\end{tabular}




\begin{tabular}{|c|c|c|c|}
\hline & & $\begin{array}{l}\text { anterior ao Aristóteles e na mitologia dos } \\
\text { indianos eles já falavam que não existia o vazio } \\
\text { que existia uma substância muito sutil que } \\
\text { preenchia tudo, que no caso era o éter. Então, } \\
\text { Aristóteles não foi o primeiro que falou em éter. } \\
\text { Muita gente antes dele que já falava do éter. }\end{array}$ & $\begin{array}{l}\text { inobserváveis } \\
\text { desde muito } \\
\text { tempo e em } \\
\text { diferentes } \\
\text { culturas. }\end{array}$ \\
\hline 8 & $11: 48$ & $\begin{array}{l}\text { P: Vocês viram que o éter vem caminhando aí } \\
\text { ao longo da história dando suporte pra se } \\
\text { entender como que alguns fenômenos } \\
\text { aconteciam, mas tinha sempre aquele ponto de } \\
\text { interrogação, né, como vamos provar? Que foi } \\
\text { até o que vocês levantaram no debate. Como é que } \\
\text { prova que o éter existe? O éter, ele serviu de } \\
\text { suporte para explicar os fenômenos e até então, } \\
\text { como as próprias teorias pra explicar, que nem no } \\
\text { nosso caso a natureza da luz, ainda vinham num } \\
\text { processo aí de... de uma reformulação pra poder } \\
\text { conseguir explicar todos os fenômenos e como o } \\
\text { éter vem caminhando aí ao longo da historia, o } \\
\text { próprio Newton ele acreditava no éter, mas ele } \\
\text { usava o éter quando precisava, né? Porque o éter } \\
\text { tem esse ponto de interrogação: a gente usa ele } \\
\text { quando necessário. [...] }\end{array}$ & $\begin{array}{c}\text { Professora } \\
\text { destaca a } \\
\text { utilidade do éter } \\
\text { e a presença de } \\
\text { incertezas e } \\
\text { dúvidas na } \\
\text { ciência. }\end{array}$ \\
\hline 27 & 31:09 & $\begin{array}{l}\text { P: Bom. Consequiências: aceitar a teoria é... } \\
\text { ondulatória... isso causou duas conseqüências } \\
\text { importantes, tá? Uma delas é a aceitação do éter, } \\
\text { porque como a gente viu, pensar na luz como } \\
\text { onda, a luz na verdade é a perturbação do meio, } \\
\text { então eu preciso acreditar no éter, senão, não tem } \\
\text { como, certo? } \\
\text { P: E a outra conseqüência, foi que isso causou um } \\
\text { impacto na comunidade cientifica, né? Porque, por } \\
\text { causa que todo mundo acreditava nas idéias do } \\
\text { Newton e o Newton era o defensor aí da teoria } \\
\text { corpuscular. Então, vocês imaginem na época o } \\
\text { que era, é... chegar com uma teoria, né, na } \\
\text { verdade retomar, lá as idéias do Huygens né, de } \\
\text { mais de cem anos atrás, quer dizer num } \\
\text { determinado período da história o Huygens foi } \\
\text { esquecido porque a teoria ondulatória não } \\
\text { encontrou força dentro da comunidade científica } \\
\text { pra se manter e seguir ai com os estudos dela, } \\
\text { então a corpuscular é que foi mais aceita. Agora } \\
\text { imagine depois disso a retomada e o que ia } \\
\text { acontecer com quem acreditava na teoria } \\
\text { corpuscular, tinha que mudar de opinião, né? }\end{array}$ & $\begin{array}{l}\text { A aceitação do } \\
\text { éter como } \\
\text { consequiência. } \\
\text { Crítica à uma } \\
\text { concepção de } \\
\text { ciência que } \\
\text { evolui } \\
\text { linearmente, } \\
\text { mostrando } \\
\text { rupturas, } \\
\text { descontinuidade. }\end{array}$ \\
\hline 31 & $38: 38$ & $\begin{array}{l}\text { P: [...] Já não se discutia mais o que que a luz era, } \\
\text { se era partícula ou era onda: já se aceitava a } \\
\text { natureza ondulatória pra luz. Com isso todos } \\
\text { tiveram que começar a aceitar que a luz era uma } \\
\text { onda, né, no éter. Mas aí, o que começou a ser a } \\
\text { pedrinha no sapato não era mais a difração }\end{array}$ & \\
\hline
\end{tabular}




\begin{tabular}{|l|l|l|}
\hline | & $\begin{array}{l}\text { porque estava explicada, mas as propriedades } \\
\text { desse éter, porque aceitando que a luz era uma } \\
\text { onda, temos que aceitar o éter, tá? }\end{array}$ \\
\hline 32 & $\begin{array}{l}\text { P: }[\ldots] \text { a comunidade cientifica começou a } \\
\text { questionar essas propriedades do éter, e } \\
\text { começaram então é... a incentivar as pesquisas em } \\
\text { cima do éter, pra detectar o éter, no caso como que } \\
\text { é a velocidade da Terra em relação a esse éter, } \\
\text { porque lembrando que o éter é uma matéria } \\
\text { muito sutil, muito leve, que os nossos sentidos } \\
\text { de visão, de tato não conseguem detectar, mas o } \\
\text { éter ta envolto aí em todo o Universo. [... Então } \\
\text { muitos experimentos começaram a dar resultados } \\
\text { e já não se tinha dúvidas sobre a existência do éter } \\
\text { no final do século XIX. Mas nem todos os } \\
\text { experimentos davam certo, tá? Então o } \\
\text { experimento do Michelson não conseguia detectar } \\
\text { aí a velocidade da Terra em relação ao éter. }\end{array}$ \\
\hline
\end{tabular}

Parece-nos que a atuação da professora na transposição didática interna foi adequada, enfatizando o papel desempenhado pelo éter em alguns momentos históricos. Tais colocações pretendiam tornar os aspectos da natureza da ciência selecionados para o curso compreensíveis para os alunos, e mostrar que há também aspectos incertos nas teorias científicas. Durante a aula os alunos permaneceram atentos, apesar de ter sido expositiva em boa parte. Eles não voltaram a questionar o éter nessa aula. Na aula seguinte, a professora fez outra revisão do conteúdo, retomando o éter e enfatizando novamente os mesmos aspectos. Depois disso, corrigiu as questões do texto 9, discutiu as dúvidas dos alunos e sistematizou o episódio III.

Um dos instrumentos utilizados para tentar acessar a compreensão dos alunos sobre o tema foi a avaliação final, onde havia a seguinte questão: "Qual era a utilidade do éter luminífero para a óptica no início do século XIX?". A maioria dos alunos apresentou respostas adequadas, mas não é possível afirmar se todos os que responderam corretamente realmente compreenderam o conteúdo, ou se reproduziram extratos dos textos, pois a prova era com consulta. Por outro lado, algumas respostas traziam a sistematização das discussões realizadas nas aulas, sugerindo a validade de nossos pressupostos iniciais e das estratégias desenvolvidas para alcançar os objetivos pretendidos em relação ao éter luminífero. Vejamos exemplos de situações variadas, inclusive de respostas inadequadas (R5): 
R1: Como se acreditava que toda onda necessitava de um meio para se transportar. Assim sendo, se a luz fosse uma onda, o éter seria o meio de transporte para a luz. Esse Éter seria muito menos denso que qualquer outra matéria, e estaria presente em todos os lugares.

R2: No século XIX a luz já era aceita como onda, sendo assim, o éter era o meio no qual ela se propagava.

R3: O éter, era uma matéria muito sutil, que ajudou a explicar muitos fenômenos que a luz exercia.

R4: A utilidade dele era que ele fazia a propagação de uma ondulação, ou seja, propagar e gerar a luz.

R5: Sem o éter luminífero não teria como enxergar no escuro graças ao éter luminífero como veriamo (sic) à noite. Assim o éter luminífero tem muita importância.

R6: O éter luminífero era essencial para a compreensão dos fenômenos ópticos, pois o éter era o meio pelo qual a luz se locomovia. Tanto para a teoria corpuscular quanto para a teoria ondulatória era necessário compreender o éter.

R7: O éter luminífero tinha como utilidade transportar a luz, já que era a teoria ondulatória que defendia a idéia de éter, eles precisavam de éter para explicar como as ondas se propagavam.

Numa perspectiva mais geral, se fôssemos nos limitar às respostas dadas pelos alunos na avaliação final, poderíamos entender que a maioria da sala atingiu o propósito pedagógico pretendido com o curso, voltado a esse aspecto do conteúdo. Grande parte dos alunos apresentou respostas satisfatórias, tendo em vista o nível de escolaridade, o tempo didático para apreender o conteúdo, a falta de pré-requisitos com os temas envolvidos e com o que nos foi possível oferecer. Entretanto, embora nossa intenção aqui não seja discutir instrumentos de avaliação, podemos afirmar não ser a avaliação final, mesmo numa perspectiva de prova operatória e com consulta, suficiente para avaliar o nível de compreensão dos conteúdos tratados com relação aos nossos objetivos.

Tendo em vista as respostas almejadas a partir dos dados, olhar para todo o processo desenvolvido ao longo do curso permite-nos obter uma visão que não seria possível, considerando-se apenas uma avaliação. As respostas nela contidas não dão conta 
de retratar os momentos de interação dos alunos com o conteúdo, gerando momentos de conflito cognitivo, como ocorreu, por exemplo, no debate.

A seqüência de interações entre os sujeitos e o saber selecionada para analisar o Evento Éter mostra que os alunos tiveram a possibilidade de vivenciar aspectos da natureza da ciência. Mais do que reproduzir conceitos, os alunos participaram ativamente de incertezas, conflitos, distintos pontos de vista, limitações nas teorias e a utilidade dos entes inobserváveis.

Não é possível dizer ter existido um único momento no curso que tenha tornado possível atingir os propósitos pedagógicos visados. Com relação ao papel dos inobserváveis, todo o processo contribuiu para isso: a preparação feita nos dois primeiros episódios, os conflitos e tensões vivenciados durante o debate prepararam os alunos para compreenderem o teatro e o episódio III. A diversidade de estratégias pedagógicas utilizadas e a atuação da professora na transposição didática interna contribuíram para os alunos protagonizarem alguns aspectos da dinâmica da construção da ciência.

\subsubsection{Evento Young}

$\mathrm{Na}$ observação dos dados escritos pelos alunos, encontramos um significativo número de respostas enfatizando que Thomas Young não possuía conhecimentos matemáticos suficientes para dar credibilidade à teoria ondulatória. Essa visão nos surpreendeu, pois nossa intenção inicial era ressaltar que a proposta ondulatória para a natureza da luz de Young resultou de muitos experimentos e de estudos teóricos a partir de uma analogia com as ondas sonoras. Com isso, pretendíamos defender que, mesmo com a realização de experimentos e uma explicação considerada adequada para a difração, as idéias de Young não receberam crédito relevante quando foram apresentadas à comunidade científica. Ao apresentarmos a teoria ondulatória de Fresnel, enfatizamos que a matematização dada a ela foi muito importante para sua aceitação na comunidade científica, destacando também a importância do apoio recebido de Arago. Entretanto, ao ressaltar a capacidade matemática de Fresnel, não imaginávamos que isso poderia levar os alunos a concluírem que Young não sabia matemática. Acreditamos que esse episódio de ensino, por nós denominado "Evento Young", contempla diversos elementos úteis à nossa análise, principalmente com relação aos obstáculos estruturais enfrentados na elaboração do Saber a Ensinar. 
Vamos apresentar esse evento, justificar sua seleção e discutir os pressupostos envolvidos na elaboração do Saber a Ensinar que deu origem a tal interpretação, e confrontá-los com os dados que mostram o processo ocorrido entre os elementos da relação didática: alunos, professor e saber. Há uma complexidade de fatores relacionados a esse evento que permite abordarmos aspectos das escolhas feitas para superar ou compensar certos obstáculos estruturais, e os riscos assumidos na elaboração do Saber a Ensinar (seções 2.3 e 3.2). Do ponto de vista histórico, que pretendíamos discutir, a resposta não apresenta grandes distorções. Entretanto, há um elemento aparentemente sutil, com implicações relevantes para esta pesquisa, conforme discutiremos a seguir.

Ao final do texto 9 para os alunos (Apêndice C.2) havia quatro questões. Duas delas motivaram vários alunos a manifestarem a idéia de que Young teria deficiências em matemática. Vejamos essas duas questões do texto 9:

3) As seguintes frases estão corretas ou erradas? Justifique.

a) "Os experimentos de Thomas Young foram suficientes para derrubar a teoria corpuscular da luz."

4) Comente um exemplo histórico para a seguinte afirmação: "Não é possível tirar conclusões apenas a partir dos experimentos, mas eles são muito importantes para a elaboração das teorias científicas".

Dos 29 alunos envolvidos com a atividade, 14 manifestaram explicitamente a visão de que Young tinha limitações matemáticas, e 5 estudantes sugeriram implicitamente essa idéia. Dos 10 alunos restantes, 9 não fizeram comentários relacionando Young e matemática, e apenas 1 deles apresentou a visão mais próxima da que esperávamos. Vejamos as transcrições:

Visão considerada mais próxima do que esperávamos, no caso do aluno mencionar relação entre Young e a matemática:

Rl para 3a) Na verdade os experimentos de Fresnel que tiveram essa função, afinal Young não utilizava os estudos matemáticos para dar respaudo(sic) a sua teoria, o que dificultava as suas justificativas. (grifo nosso).

Transcrição de algumas respostas indicando uma visão de Young ter limitações matemáticas: 
R1 para 3a) Errado, pois ele não possuía conhecimentos matemáticos para conseguir firmar sua teoria.

R2 para 3a) Errada. Apesar dos experimentos de Young serem corretos e válidos, não foram aceitos, pois não havia análise matemática nem um estudo mais profundo. A teoria só foi aceita com Fresnel, que fez a parte matemática do experimento.

R3 para 3a) Errada, apesar de Thomas Young ter retomado a pensar na luz como onda, ele não conseguia provar muito bem, pois não tinha muito conhecimento em matemática, além de não ter muito "status", o que era um pouco necessário.

R4 para 4) Podemos usar como exemplo Thomas Young, que era um cientista que apresentou várias teses com muitos experimentos, porém não possuía um vasto conhecimento matemático, e não conseguiu estabelecer formular matematicamente sua tese. E contou com o apoio de Fresnel que tinha uma base matemática maior, porque seu tempo era mais avançado. (grifo nosso)

R5 para 4) Um exemplo foi Thomas Young que fez muitos experimentos, mais por falta de base matemática não foi levado à sério, só mais tarde quando Fresnel deu sua contribuição matemática que seus estudos foram levados à serio.

R6 para 4) Um exemplo foi Thomas Young que realizou experiência para a teoria ondulatória, ele basicamente explicou a difração, segundo a ondulatória, mas não tinha base matemática, porém, foi muito importante p/ o desenvolvimento teórico.

Exemplo de uma resposta que consideramos sugerir limitações no domínio da matemática:

R7 para 4) Thomas Young tinha experimentos mas não tinha análise matemática por esse motivo não conseguiu provar a teoria ondulatória.

As demais respostas com essa concepção foram variações muito próximas das situações acima.

Essas respostas nos pareceram surpreendentes, pois não tínhamos a intenção de propor tal interpretação no material do curso, e um número expressivo de estudantes apresentou a mesma visão. Além de não constar explicitamente no material do curso, pareceu-nos, inicialmente, pouco provável essa concepção ter sido sugerida, de algum modo, já que não retrata o nosso ponto de vista sobre Thomas Young. De fato, já foi 
bastante discutido na literatura educacional, que os valores, as crenças e as idéias sobre um determinado assunto permeiam o discurso de um professor em sua aula, ou de um autor em sua obra (GIL PEREZ et al., 2001). Nesse caso, como não compartilhamos essa idéia de que Thomas Young não soubesse matemática, pareceu-nos pouco provável nós a termos sugerido.

Buscamos investigar quais aspectos do material poderiam ter contribuído para fomentar essa visão, refletindo inicialmente sobre os pressupostos adotados na elaboração do Saber a Ensinar vinculado ao Evento Young.

Quando selecionamos o conteúdo do episódio III para o curso, tínhamos como objetivo mostrar para os alunos o debate entre duas explicações possíveis para a natureza da luz, buscando problematizar aspectos de natureza epistemológica. As escolhas feitas e os riscos assumidos foram guiados por vários pressupostos que serviram de balizadores, por exemplo, o nível de escolaridade focalizado; a ausência de pré-requisitos matemáticos, históricos e filosóficos dos alunos; a falta de tempo para detalhar o contexto; o domínio técnico dos fenômenos ópticos, etc. (seções 3.2.3 e 3.2.4).

Pretendíamos superar alguns obstáculos, compensar certas limitações e enfrentar alguns dilemas/conflitos na construção de estratégias pedagógicas. Por isso, alguns conceitos foram introduzidos nos dois episódios anteriores, conforme discutimos no capítulo 3 (seções 3.2 .3 e 3.2.4). Devido ao número de aulas disponíveis para todo o curso e o tempo já destinado aos episódios anteriores, não seria possível aprofundar a análise dos estudos de Young sobre a difração.

$\mathrm{Na}$ tentativa de compensar a falta de pré-requisitos dos alunos para compreender a difração luminosa mediante uma concepção corpuscular para a luz, utilizamos o recurso visual proporcionado pelo trecho inicial do filme Dr. Quantum. A animação ilustra o experimento da dupla fenda que compara os fenômenos da difração e interferência luminosa, mediante concepções ondulatória e corpuscular para a luz (seção 3.2.7). Por meio de analogias entre as bolinhas e uma concepção corpuscular para a natureza da luz, e as ondulações na água e uma concepção ondulatória para a luz, o Dr. Quantum (personagem da animação) esclarece por que não é possível explicar o fenômeno da difração luminosa mediante uma concepção corpuscular para a luz.

Outro recurso por nós utilizado visando a fornecer subsídios aos alunos para compreenderem os fenômenos envolvidos, foi a demonstração experimental da difração e 
superposição luminosas, e a demonstração da formação das franjas de interferência no anteparo durante a revisão dos fenômenos ópticos (veja o planejamento do curso e os textos no Apêndice C; a revisão nos slides no Apêndice C.4 e C.6).

Portanto, a compreensão do fenômeno viria por meio das atividades apresentadas acima: as demonstrações experimentais e a animação Dr. Quantum. Consideramos que, para os propósitos desse curso, seria suficiente enfatizar o fato de Young ter realizado vários experimentos e estudado o fenômeno da difração luminosa por meio de uma analogia com as ondas sonoras.

Essas atividades não apresentavam a formulação matemática de Fresnel para a teoria ondulatória, principalmente devido à falta de pré-requisitos dos alunos em termos matemáticos, e à complexidade de sua teoria. A matematização, que nos parece ter sido decisiva para a aceitação da teoria ondulatória, não se restringe à explicação do fenômeno da difração, mas estende-se a toda a teoria, que propõe, entre outras coisas, o arrastamento parcial do éter luminífero pelos corpos transparentes (MARTINS, no prelo; PIETROCOLA, 1993a).

Desse modo, com as limitações de tempo para o curso, dos pré-requisitos conceituais dos alunos e com o recorte adotado, não pareceu necessário investir na comparação entre as explicações matemáticas dadas por eles ao fenômeno da difração. Se optássemos por incluir uma nova etapa para aprofundar esses conteúdos, excederíamos o tempo para a aplicação do curso que nos foi disponibilizado, além de estender a quantidade dos textos dos alunos e o texto de leitura para o professor, o que tornaria a proposta do curso mais distante da realidade do ambiente escolar. Não podemos nos esquecer de que as 20 horas-aula utilizadas para o curso correspondem praticamente a um bimestre letivo. Quantos professores e escolas estariam dispostos a destinar tantas horas-aulas para abordar conhecimentos sobre a natureza da ciência?

Além do destaque dado a esse conteúdo na história da óptica atualmente, a menção feita a Thomas Young e sua proposta ondulatória para a luz visava, principalmente, a apresentar aspectos da natureza da ciência (seções 3.2 .3 e 3.2.4). Enquanto uma concepção ondulatória para a natureza da luz proposta anteriormente por Young não recebeu créditos nem destaque significativo na sua época, alguns fatores não científicos podem ter contribuído para a aceitação da teoria ondulatória de Fresnel, como o apoio técnico e estratégico que recebeu de Arago. Problematizou-se, também, embora indiretamente, que o 
fato de um pensador apresentar uma explicação razoável para um fenômeno não teria sido suficiente para reacender o debate entre as teorias na comunidade científica, que aderia maciçamente à teoria corpuscular.

Outro benefício em abordar a explicação de Young para a natureza da luz baseada em uma analogia com as ondas sonoras e a teoria de Fresnel, destacando sua matematização, é mostrar que ambas requeriam a existência de um ente inobservável. Buscamos enfatizar que, mesmo as propostas de ambos tendo sido fundamentadas por diferentes caminhos, as duas requeriam a existência de um suporte para a luz, o éter luminífero. No início do século XIX, prevalecia no ideário da ciência a busca pela experimentação, pela mensuração, e por uma suposta observação objetiva dos fenômenos. Nesse cenário, em que era muito forte o ideal de racionalidade e empirismo, seria contraditório admitir a existência de um ente inobservável na elaboração de explicações científicas. Tal discussão possibilitou problematizar mais aspectos da natureza da ciência (veja textos 7, 8 e 9 para os alunos no Apêndice C).

Sem dúvida, destacamos que o fato de Fresnel ter apresentado sua teoria ondulatória com uma formulação matemática rigorosa para a época, teria sido decisivo para sua aceitação (BUCHWALD, 1989a; WORRALl, 1994). Contudo, isso não implica, necessariamente, que Thomas Young não soubesse matemática. $\mathrm{O}$ ponto relevante a despontar nessa análise é que, por contraste à forte afirmação de ser a teoria de Fresnel bem matematizada, e pelo fato de ela ter sido emblemática na concepção de luz no início do século XIX, os alunos, ou a professora, deduziram por uma insuficiência de Young em matematização.

Esses detalhes podem parecer muito sutis, ou mesmo irrelevantes, mas preocupamnos menos pela incorreta interpretação do fato histórico, e mais pelas implicações trazidas para a pesquisa. O Evento Young decorre do processo de enfrentamento de um conjunto de obstáculos estruturais, que, a nosso ver, estarão sempre permeando as iniciativas do uso da história da ciência no ensino de ciências: que aspectos do conteúdo histórico devem-se enfatizar, tendo em vista os objetivos almejados? Que detalhes históricos relativos aos conceitos científicos podem-se ou devem-se omitir? Que aspectos do contexto sociocultural do período ou de fatores extra científicos devem ser mencionados, ou ainda, devem ser omitidos? 
Em nossa escolha, buscamos selecionar os aspectos mais relevantes para atender a nosso objetivo educacional, e cuidamos para apresentá-los diacronicamente, na medida do possível. Porém, parece que a distorção no conteúdo histórico, e que de certo modo distorce também aspectos da construção da ciência, foi ocasionada pela necessidade de simplificação adotada, ou por aspectos omitidos.

De fato, a capacidade matemática de Young não era o tema de nossa discussão, e, tendo em vistas os riscos assumidos, não podemos considerar que esse tenha sido um problema. Mas esse evento torna-se uma rica fonte de dados para a pesquisa, por sugerir que a omissão de determinados aspectos científicos poderiam ocasionar distorções de natureza epistemológica.

Fresnel saber mais matemática que Young é um fato de menor importância aqui. A reflexão sobre esse evento aponta para fatores mais complexos. Será possível antever todas as possíveis conseqüências das omissões inevitáveis, ao construírem-se narrativas da história da ciência voltadas ao ambiente escolar? Ou ainda, seria necessário antevê-los? Em que medida? Quando?

Buscamos na análise do sistema didático, onde ocorre a interação entre professor, alunos e o Saber a Ensinar, desvelar mais aspectos concorrentes para o Evento Young acontecer.

Iniciamos pela análise do material didático. Os alunos tiveram contato com o conteúdo do século XIX a respeito de Young em quatro recursos pedagógicos distintos: o roteiro para o teatro, no texto 9, na apresentação em slides e na abordagem do professor. No texto 8, que traz o roteiro para o teatro (Apêndice D.4), não há nenhuma afirmação passível de sugerir uma limitação matemática de Young; tampouco há qualquer comentário exaltando a capacidade matemática de Fresnel. O texto 9. que faz a sistematização do episódio III (Apêndice C.2), também não emite qualquer comentário sobre Young e matemática, e a única menção sobre matemática vinculada a Fresnel é uma afirmação de que a sua teoria incluía equações matemáticas.

Os dados apontaram para dois momentos que parecem ter ocasionado o Evento Young: o conteúdo dos slides e a explicação da professora.

A apresentação em slides 3b: Éter e luz no século XIX para o episódio III (Apêndice C.7) traz elogios ao trabalho de Young e uma ênfase na matematização de 
Fresnel para sua teoria ondulatória. Provavelmente, o conteúdo da apresentação possa ter contribuído para os alunos concluírem que Fresnel possuía mais domínio da matemática que Young. Vejamos alguns trechos desses slides:

"Seus estudos [de Young] foram muito bem feitos, mas não convenceram praticamente ninguém."

"Seu trabalho [de Fresnel] era mais sofisticado que o de Young, sob o ponto de vista matemático.”

"Fresnel se candidatou com um estudo que apresentava a teoria matemática da difração."

"Sua capacidade matemática [de Fresnel] era muito grande, e seus resultados impressionaram profundamente os físicos da época”.

Esses dados apontam para aspectos que precisam ser levados em conta no momento de lidar com os obstáculos estruturais na elaboração do Saber a Ensinar. Como não iríamos apresentar os estudos de Young e de Fresnel em detalhes, pareceu-nos necessário enfatizar a importância, realmente decisiva na época, da matematização dada por Fresnel para a aceitação da teoria ondulatória. Naquele momento, não imaginávamos que tal ênfase poderia sugerir desconhecimento de Young sobre matemática. Hoje, temos a impressão de que eles sobrevalorizaram as habilidades de Fresnel.

O fato mais evidente de ter concorrido para o Evento Young foi a atuação da professora na transposição didática interna. Vejamos a transcrição do trecho da aula em que a professora explica o conteúdo da apresentação em slides 3b (Apêndice C.7). Durante a apresentação os alunos não se manifestaram, portanto ocorreu apenas a fala da professora. Vejamos alguns trechos da explicação (Anexo A):

17/9/2007 - Aulas 13 e 14 - Arquivo I

\begin{tabular}{|c|c|l|c|c|}
\hline Turno & Tempo & \multicolumn{1}{|c|}{ Falas } & Observações \\
\hline 28 & $32: 32$ & $\begin{array}{l}\text { P: Bom. O Thomas Young, né, como eu falei, ele era } \\
\text { médico e aí ele começou a defender a teoria } \\
\text { ondulatória da luz. Só que o Young, ele fez o } \\
\text { experimento, ele se dedicou ao estudo, mas é... } \\
\text { faltava pra ele um pouco mais de aparato } \\
\text { matemático pra poder explicar é... a luz como onda, } \\
\text { né? Então ele lançou a idéia, ele fez os estudos, os } \\
\text { experimentos, ele elaborou a teoria, mas faltou pra } \\
\text { ele é... Vamos dizer assim alicerce matemático }\end{array}$ & $\begin{array}{c}\text { apéno } \\
\text { clacosico. }\end{array}$ \\
\hline
\end{tabular}




\begin{tabular}{|c|c|c|c|}
\hline & & $\begin{array}{l}\text { mesmo pra ele conseguir defender mesmo a idéia dele. } \\
{[\ldots]} \\
\text { Foi o Fresnel, que } 20 \text { anos depois do Young, ele } \\
\text { começou a estudar o mesmo experimento da fenda } \\
\text { dupla, da difração, e ele era um excelente } \\
\text { matemático, então aí ele teve, né, todo o aparato } \\
\text { que a matemática precisava pra explicar o } \\
\text { fenômeno. Então ele abraçou, né, a idéia de que a luz } \\
\text { na verdade é onda. [...] }\end{array}$ & \\
\hline 29 & $35: 02$ & $\begin{array}{l}\text { P: [...] Então, em 1817, a Academia de Ciências } \\
\text { propõe um prêmio pra quem explicasse melhor o } \\
\text { fenômeno da difração, tá, de forma quantitativa } \\
\text { porque tinha que ter além de uma teoria bem } \\
\text { elaborada, a análise matemática dela também. [...] } \\
\text { Bom, o Fresnel, com o apoio do Arago, ele se } \\
\text { candidatou, apresentou o estudo dele, né, com toda } \\
\text { teoria matemática que explicava a difração. É... na } \\
\text { verdade, só recapitulando né, foi o Huygens que } \\
\text { lançou primeiro a idéia de que a luz seria onda, quase } \\
\text { cem anos depois o Young retomou os experimentos, e } \\
\text { o Fresnel, né, manteve contato, ele não leu os } \\
\text { trabalhos do Young, mas ele manteve contato com o } \\
\text { Young, trocaram idéias, e aí ele deu o reforço aí } \\
\text { matemático que a teoria do Young estava } \\
\text { precisando. [...] }\end{array}$ & $\begin{array}{c}\text { Alunos } \\
\text { continuam } \\
\text { atentos. }\end{array}$ \\
\hline 30 & $38: 12$ & $\begin{array}{l}\text { P: Bom, ele publicou outros trabalhos com o apoio do } \\
\text { Arago, e que chegou à conclusão então do reforço } \\
\text { aqui, né, pra se aceitar a teoria ondulatória pra luz. Foi } \\
\text { graças à capacidade matemática que ele tinha que } \\
\text { ele foi que conseguiu explicar o fenômeno da } \\
\text { difração com todo o apoio da teoria da matemática. } \\
\text { [...] }\end{array}$ & \\
\hline
\end{tabular}

Nos slides, observou-se a ênfase na capacidade matemática de Fresnel e no desenvolvimento matemático sofisticado que ele teria dado à teoria, mas não há afirmações de que Young não soubesse matemática. No entanto, uma leitura subliminar do texto pode, por contraste, dar a idéia de que Young não dominava a matemática. Por outro lado, na fala da professora, essa idéia surgiu de modo explícito. Os dados sugerem que a omissão específica a respeito da capacidade matemática de Young ocasionou essa interpretação por parte da professora, e ela acabou por enfatizar a matematização dada por Fresnel como um avanço em relação aos estudos desenvolvidos por Young.

É provável que esse assunto não tenha sido abordado de maneira clara durante as reuniões de preparação com a professora (seção 3.3.2). Entretanto, como não temos as gravações dos diálogos, não é possível saber se algo poderia ter sugerido essa idéia. Vale a 
pena relembrar que o fato de não termos essa concepção de que Young não soubesse matemática pode significar mais a ausência de uma abordagem a respeito desse assunto, do que termos implicitamente sugerido uma idéia que não defendemos.

Parece-nos pouco provável, também, tal concepção possa ter sido ocasionada pelo texto voltado ao professor, pois a única menção a Young e Fresnel foi bastante simplificada, como se vê na transcrição abaixo:

"Vamos mostrar aos alunos alguns acontecimentos que envolveram a crescente aceitação da teoria ondulatória entre os homens da ciência no início do século XIX, buscando refletir sobre como se dá a construção do conhecimento científico:

- O experimento de difração de Thomas Young (1773-1829) e a dificuldade em explicá-lo utilizando a teoria corpuscular (PIETROCOLA, 1993b).

- Os resultados encontrados por experimentos realizados por François Arago (17861853), que também não eram explicados pela teoria corpuscular (PIETROCOLA, 1993b).

- O prêmio proposto pela Academia de Ciências francesa em 1817 para o melhor trabalho sobre o fenômeno da difração, cujo vencedor foi Augustin Fresnel (1788-1827) com um trabalho que defendia a teoria ondulatória (PIETROCOLA, 1993b; WhitTAKER, 1953).

- O prestígio de Arago e seu apoio a Fresnel contribuindo para a apresentação de sua teoria à comunidade científica da época (LEVITT, 2000).

- O papel do éter luminífero na teoria ondulatória para a natureza da luz (WoRRALL, 1994)." (Apêndice A, p. 21-30).

Percebemos que o texto para o professor não faz menção a essa questão, portanto ele não deve ter influenciado diretamente a concepção da professora. Na época da elaboração desse texto, para não torná-lo mais longo, optamos por apenas complementar as idéias constantes no texto dos alunos, e relacionar os aspectos tratados na bibliografia básica fornecida ao professor aos propósitos pedagógicos do curso (ver seção 3.3.1). Entretanto, é necessário ter em mente que, muitas vezes, ao se omitir uma referência, deixa-se espaço para o professor preenchê-lo "como quiser". Nesse caso, como não fícou claro no texto em que aspecto a teoria de Fresnel é superior à de Young, a professora fez sua própria interpretação. 
A elaboração desse Saber a Ensinar exigiu que o Saber Sábio fosse descontextualizado, despersonalizado e dessincretizado com relação ao seu contexto original, para então, ser novamente recontextualizado ao ambiente escolar. Nesse processo, foi inevitável estabelecer um rigoroso recorte, que acabou por "simplificar" algumas abordagens do ponto de vista histórico, omitir alguns aspectos históricos e científicos e compensar aspectos inacessíveis aos alunos, utilizando estratégias pedagógicas para a superação ou compensação de obstáculos (seções 3.2 e 4.1). Foi o caso, inevitável, de omitir a matematização das teorias, os contextos que permearam os estudos de Young e Fresnel, dentre muitos outros.

O Evento Young sugere que a omissão de informações levou a professora a construir, no interior do sistema didático (na sala de aula), uma concepção própria sobre o evento. De certo modo, isso indica que, apesar de todo o esforço realizado na elaboração do Saber a Ensinar, buscando construir uma narrativa história diacrônica, não foi o suficiente para garantir a fidedignidade do contexto epistemológico.

Podemos adiantar como hipótese que, na ausência de uma informação específica para esse aspecto, tenha prevalecido uma concepção intuitiva da professora sobre a natureza da ciência, forjada, provavelmente, numa ocasião anterior, que o material e as reuniões de preparação não foram capazes de alterar. Esta hipótese, embora passível de confirmação, ganha apoio no fato de que a história é normalmente contada do ponto de vista do vencedor (ALLCHIN, 2004). Em geral, é o personagem que reúne as qualidades que fazem a diferença para cada contexto, por exemplo, astúcia, recursos materiais, e no caso da ciência, habilidades técnicas (sejam teóricas ou experimentais) costumam explicar a vitória de um sobre outros.

Discutimos nesta seção a análise de três eventos que possibilitaram averiguarmos várias das questões levantadas na elaboração do curso. Dentre outras coisas, tratamos do risco de relativismo apontado pela dimensão teórica da pesquisa, a relação do aluno com a complexidade da idéia de éter e como isso possibilitou a vivência de aspectos da natureza da ciência, e a possibilidade de interpretações equivocadas em decorrência da omissão de uma abordagem matemática. Na seção seguinte, relatamos situações que permitem compreender um pouco mais o contexto de aplicação do curso piloto. 


\subsection{Relatos e percepções: Um breve olhar para o processo}

Vamos apresentar a seguir duas situações ocorridas no curso, que não puderam ser consideradas "eventos de pesquisa", seja porque não reuniram predicados de análise, seja porque dificuldades técnicas limitaram a qualidade dos dados. Apesar disso, apontaram detalhes que permitem esclarecer alguns resultados obtidos na aplicação do curso.

\subsubsection{Recortes e descaminhos: a história da linha do tempo}

Um dos desafios apontados na construção do curso (seções 3.2 e 4.1) foi encontrar modos de estabelecer o recorte dos episódios históricos que permitissem uma interpretação diacrônica da história da ciência. Isso envolveu selecionar os conteúdos históricos, filosóficos e físicos a serem omitidos, como abordar os aspectos eleitos de modo a ser acessível ao estudante do ensino médio, etc.

Optamos pela utilização da linha do tempo (descrita na seção 3.2.5 e retomada na seção 4.1.2), com imagens de pensadores e de filmes históricos. Buscávamos contornar o desafio OC8 "extensão versus profundidade", que possibilitaria localizar de modo relativamente rápido a época em que ocorreu cada episódio tratado pelo curso (Apêndice 4.2).

A faixa contendo a linha do curso foi afixada na parede da sala e a professora deveria chamar a atenção dos alunos durante as aulas para os pensadores em estudo, bem como para o período histórico sob enfoque.. Contudo, houve um imprevisto a dificultar esse plano inicial. Ao lado da sala em que o curso foi aplicado, havia uma turma excessivamente barulhenta. Percebemos que alguns dados gravados ficaram inaudíveis, em função dos ruídos externos, e decidimos realizar a maior parte das outras aulas na sala de vídeo. Com isso, a faixa foi pouco aproveitada durante o curso, e não pudemos validar nossa hipótese. Conseguimos apenas perceber, pelos dados tomados durante a realização da atividade, a confirmação do pressuposto de que os alunos tinham dificuldades para localizar os pensadores e episódios históricos na dimensão temporal. Vejamos alguns desses dados:

Essa atividade ocorreu na primeira aula do curso. Conforme esclarecido na seção 3.2.7, a atividade foi iniciada com o jogo "colocando na linha do tempo", em que os alunos receberam 19 cartões com pensadores e eventos históricos para organizá-los cronologicamente (Apêndice D.1). Eram eles: Demócrito de Abdera; Christiaan Huygens; 
Aristóteles; François Arago; Isaac Newton; Thomas Young; Platão; César Lattes; Empédocles; Leonardo da Vinci; Fresnel; Einstein; Descobrimento do Brasil; Nascimento de Jesus; Vôo do 14 Bis; Guerra de Tróia; Independência do Brasil; As Cruzadas; Bomba atômica de Hiroshima.

Os alunos demoraram cerca de 20 minutos para organizar os cartões cronologicamente. A professora iniciou o levantamento das propostas:

\begin{tabular}{|c|c|c|c|}
\hline \multicolumn{4}{|c|}{ 6/9/2007 - Aulas 1 e 2 - Arquivo I } \\
\hline Turno & Tempo & Falas & Observações \\
\hline 13 & $17: 27$ & P: Gente, ó, mais uns 2 minutinhos. & $\begin{array}{l}\text { A maioria da sala } \\
\text { continua animada, } \\
\text { trocando informações } e \\
\text { empenhada na atividade. }\end{array}$ \\
\hline 14 & 18:21 & & $\begin{array}{c}\text { Há três alunos no fundo } \\
\text { direito da sala que } \\
\text { participaram bastante, } \\
\text { mas começam a ficar } \\
\text { quietos. As expressões } \\
\text { sugerem um pouco de } \\
\text { frustração. Olham } \\
\text { pensativos para os } \\
\text { cartões. }\end{array}$ \\
\hline 15 & $20: 37$ & $\begin{array}{l}\text { P: [...] Vocês já devem ter uma noção de qual } \\
\text { seria desses que, desses que vocês têm aí, qual } \\
\text { seria o primeiro? Fala Pedro. } \\
\text { Pedro: Guerra de Tróia }\end{array}$ & \\
\hline 16 & 21:24 & $\begin{array}{l}\text { P: Guerra de Tróia? Que mais? } \\
\text { Alunos ( } 2 \text { ou 3): Guerra de Tróia. }\end{array}$ & \\
\hline 17 & $21: 33$ & $\begin{array}{l}\text { A5: Nascimento de Jesus. } \\
\text { P: Nascimento de Jesus? Quem dá mais? } \\
\text { A6: Empédocles. }\end{array}$ & $\begin{array}{l}\text { A professora brinca } \\
\text { motivando os alunos a } \\
\text { responderem. }\end{array}$ \\
\hline 18 & $21: 37$ & $\begin{array}{l}\text { P: Empédocles ta na ponta... Ó, aqui é o } \\
\text { Platão que tá no início, ta. Então... } \\
\text { A7: Demócrito... } \\
\text { P: Aqui é o Demócrito. }\end{array}$ & \\
\hline
\end{tabular}

As respostas dos grupos foram diferentes e apenas 2 dos 9 grupos colocaram Guerra de Tróia. Pode-se perceber, pelas imagens gravadas, que muitos alunos não tinham idéia sobre quem eram os pensadores e alguns acontecimentos tratados. Houve respostas bem diferentes entre os grupos para o primeiro fato do período abordado: a Guerra de 
Tróia, o nascimento de Jesus, Empédocles, Demócrito e Platão, foram as respostas dadas pelos grupos como primeiro evento na linha cronológica.

Quando a faixa foi aberta e começou a ser afixada na parede, praticamente todos dos alunos permaneceram comparando suas respostas com a cronologia da faixa. A atitude dos alunos durante toda a atividade (observada no vídeo), e os comentários nas anotações de campo sugerem que o restante da linha cronológica estava diferente também.

A dificuldade da maioria dos alunos em localizar as informações no tempo sugere como o apoio da faixa teria sido proveitoso para localizar na história os três episódios e os personagens a serem tratados no curso. Entretanto, não conseguimos utilizar esse recurso conforme planejado e, assim, não obtivemos dados para essa análise. Desse modo, pouco podemos concluir com segurança.

\subsubsection{A relação professora-alunos: afeto e valorização como diferencial}

Um aspecto que nos chamou a atenção durante a análise dos dados foi o modo como a professora valorizava os alunos em vários momentos do curso. Ela fazia elogios, dizendo confiar em sua capacidade, responsabilidade e comprometimento. Nesses momentos, as expressões dos alunos no vídeo mostram segurança, alegria e "afeto" pela professora. Embora a dimensão afetiva do contrato didático não faça parte dos objetivos desse trabalho, esse dado tornou-se tão visível na observação dos vídeos, que decidimos mencioná-lo. Vejamos algumas falas da professora.

Ao final da exposição dos grupos na atividade do debate, a professora finaliza essa etapa e pede que os jurados se reúnam para chegar a um veredicto. Nesse momento ela elogia o desempenho dos alunos e enfatiza sua confiança em sua capacidade:

\begin{tabular}{|c|c|l|c|}
\hline \multicolumn{5}{|c|}{ 13/9/2007 - Aulas 9 e 10 - Arquivo II } \\
\hline Turno & Tempo & \multicolumn{1}{|c|}{ Falas } & \multicolumn{1}{|c|}{ Observações } \\
\hline 136 & $04: 50$ & $\begin{array}{l}\text { P: [...] em primeiro lugar eu gostaria de } \\
\text { agradecer as, os dois grupos, porque... eu } \\
\text { reconheço que essa discussão não é fácil. [...] } \\
\text { porque vocês meio que tomaram } \\
\text { conhecimento desse assunto nesse módulo, } \\
\text { né... No geral, não só de éter, de ondas, de } \\
\text { teoria da luz, de tudo... é tudo novidade pra } \\
\text { todos da sala. Então, assim, é... pra mim foi... } \\
\text { é lógico que eu tinha a minha aposta em }\end{array}$ & $\begin{array}{c}\text { aos alunos: } \\
\text { Professora } \\
\text { agradece e } \\
\text { valoriza os alunos } \\
\text { em vários } \\
\text { momentos do } \\
\text { curso. }\end{array}$ \\
\hline
\end{tabular}




\begin{tabular}{|l|l|}
\hline & $\begin{array}{l}\text { vocês, né... mas, pra mim foi muito bom. } \\
\text { Porque eu senti que ambos os grupos se } \\
\text { empenharam [...]Então eu agradeço aos dois } \\
\text { grupos, e também a platéia que também, é, } \\
\text { participou questionando e tal... tá? }\end{array}$ \\
\hline
\end{tabular}

$\mathrm{Na}$ seqüência, os membros do júri reuniram-se para discutir e chegar a um consenso. Ao final das discussões, o veredicto foi dado e a professora fez breve sistematização do conteúdo, destacando a crítica às idéias de provas na ciência e a influência de fatores não científicos na construção do conhecimento científico. Novamente ela faz elogios aos alunos:

\begin{tabular}{|l|l|l|l|}
\hline \multicolumn{5}{|c|}{$13 / 9 / 2008$ - Aulas 9 e 10 - Arquivo II } & Observações \\
\hline Turno & Tempo & \multicolumn{1}{|c|}{ Falas } & \multicolumn{1}{|c|}{$\begin{array}{l}\text { P: [... Mas assim... Júri, turma do corpuscular e } \\
\text { turma das ondas, vocês estão de parabéns, eu } \\
\text { estou muito feliz com o curso, estou muito } \\
\text { feliz por vocês, que vocês estão se } \\
\text { empenhando, a gente sabe das limitações de } \\
\text { vocês... eu também, como professora, também } \\
\text { tenho a minha limitação. Então, ta legal porque } \\
\text { a gente tá aprendendo junto, vocês estão } \\
\text { levantando questões, isso ta sendo muito legal e } \\
\text { o empenho de vocês também está sendo muito } \\
\text { legal. É aquela coisa que eu não apostei em } \\
\text { vocês a toa. }\end{array}$} \\
\hline
\end{tabular}

O acompanhamento do curso, a análise dos dados, as conversas com a professora, as falas dos participantes nos corredores antes e depois das aulas nos autorizam a afirmar que o curso superou as expectativas em termos de engajamento dos alunos, nível de discussões levadas a cabo e sentimento de crescimento intelectual, verbalizados em vários momentos, e escritos na pesquisa final que acompanhou a prova. Diante disso, é pertinente indagar até que ponto esse retorno positivo de afeto, encorajamento e confiança que a professora demonstrava pelos alunos, pode ter contribuído para o envolvimento deles? Pretendemos investigar essa dimensão afetiva da relação professor-aluno em trabalhos futuros como um dos desdobramentos dessa tese. 


\subsection{Destacando resultados}

As análises acima permitiram obter elementos de respostas aos desafios enfrentados (OS e OC), que descrevemos na seção 4.1. Vamos retomar algumas propostas feitas para superar ou compensar os obstáculos e apontar algumas conclusões.

\subsubsection{Muitos textos: um risco?}

Um dos desafios enfrentados na preparação do curso foi com relação à quantidade de textos suficientes para abordar o conteúdo histórico-epistemológico, sem tornar o curso desestimulante para os estudantes (OC7). Conforme descrevemos na seção 4.1, decidimos assumir o risco de entregar os nove textos para os alunos e realizar a leitura com eles em sala de aula.

A análise dos dados, as percepções realizadas durante o acompanhamento das aulas e o retorno dado pela professora nas reuniões, durante e após o curso, permitiram-nos concluir que a estratégia adotada foi adequada. A leitura de todos os textos não demonstrou ser enfadonha em nenhum momento observado. $\mathrm{O}$ risco assumido aqui era com relação à quantidade de textos, pois julgamos que a textualização adequada ao nível de escolaridade enfocado seria um obstáculo superável (4.1).

Essa conclusão volta-se para esse caso específico, naturalmente. Nada pode garantir que tal quantidade de textos não poderia ser considerada demasiada em outros contextos educacionais. Entretanto, os caminhos tomados nessa experiência piloto podem apontar indicativos e sugestões para novas propostas, em diferentes contextos. Provavelmente, a variedade de atividades e o notório envolvimento dos alunos com o tema do curso contribuíram para que a quantidade de textos estudados não se configurasse excessiva.

\subsubsection{Compensar a omissão da matemática com recursos visuais?}

Os fenômenos ópticos abordados no curso não foram estudados do ponto de vista matemático (OC4). Essa decisão foi resultado da confluência de várias necessidades, pressupostos e objetivos. Tínhamos pouco tempo disponível para a aplicação do curso e uma grande quantidade de conteúdo histórico selecionado para viabilizar o estudo dos conteúdos epistemológicos. Os alunos não haviam estudado boa parte do conteúdo conceitual envolvido no curso, como a difração e a interferência luminosas, por exemplo. Se fossemos tratar matematicamente todos os fenômenos ópticos, necessitaríamos de mais 
aulas do que as concedidas. Desse modo, foi necessário pensar em outras formas de abordar os aspectos dos conceitos ópticos fundamentais para os objetivos do curso. Recorremos às imagens nos slides, à demonstração experimental de alguns fenômenos, como a dispersão da luz branca em um prisma, a formação das sombras, a difração e a interferência luminosas. Utilizamos a animação "Dr. Quantum" a fim de esclarecer a questão fundamental para o curso: a limitação da teoria corpuscular em explicar os padrões de interferência resultantes da superposição de ondas luminosas. Adotar um recurso predominantemente visual para todos os fenômenos, sem a costumeira abordagem matemática, era um risco que decidimos assumir.

A observação das aulas e a subseqüente análise dos dados viriam a sugerir, posteriormente, que essa escolha atendeu em parte aos propósitos do curso. Não identificamos problemas com relação à compreensão dos fenômenos ópticos abordados. Nesse sentido, os recursos que visavam a compensar a omissão da matemática pareceramnos satisfatórios. Entretanto, conforme pudemos acompanhar no evento Young, houve uma excessiva valorização da capacidade matemática de Fresnel, em detrimento de Young. A ausência de uma comparação explícita entre os caminhos tomados por Young e Fresnel parece ter sugerido que Young não sabia matemática.

Isso tudo possibilita a inferência de dois resultados:

a) utilizando-se de demonstrações experimentais, dos relatos das proporções dos experimentos de Newton com o prisma, das representações geométricas nas figuras dos slides, e do filme Dr. Quantum, foi possível compensar a omissão da matemática para os propósitos desse curso específico. Pretendíamos ensinar sobre a natureza da ciência e não sobre conceitos físicos. Nesse sentido, compreender os fenômenos sem sua matematização formal foi suficiente para nossos objetivos. Não acreditamos que tais recursos seriam válidos quando se pretende ensinar o conteúdo da ciência. Eles poderiam ser usados como introdução ao estudo dos fenômenos, facilitando ao estudante sua compreensão, mas não podem substituir a abordagem matemática para o seu aprendizado, enquanto conteúdo científico.

b) pode ser que a ausência da matematização dos trabalhos de Young e Fresnel tenha permitido à professora concluir que Young não sabia matemática. Contudo, não sabemos se, prevendo essa interpretação, uma orientação específica bastaria, 
sem a necessidade de apresentar os diferentes enfoques adotados por ambos ao propor uma concepção ondulatória para a luz.

\subsubsection{Entes inobserváveis: complexas abordagens}

O conteúdo que mais parecia favorecer nossos propósitos pedagógicos era também nosso maior desafio na elaboração do curso: discutir o éter luminífero e o papel dos inobserváveis na elaboração de explicações científicas (OS5 e OS8). Decidimos manter o conteúdo, mesmo com os riscos previstos. Nossas estratégias pedagógicas para lidar com esse conteúdo permitiram abordá-lo em distintas atividades pedagógicas e em todos os episódios históricos. A idéia iria surgindo aos poucos, inicialmente permeando a explicação da luz para Aristóteles e depois para Huygens, até ir recebendo mais destaque ao final do episódio II. Ele foi tratado enfaticamente na atividade do teatro, para finalmente ser abordado no episódio III.

No evento éter, percebemos que esse conteúdo permaneceu difícil para os alunos até o final do curso. Nas aulas finais alguns alunos pareciam mais tranqüilos com o conceito, mas um número significativo de estudantes ainda o achava complicado. Este desafio foi considerado como um obstáculo superável, mas se nosso objetivo fosse ensinar o conceito de éter, ele teria sido parcialmente atingido, visto que parte dos estudantes acharam difícil compreender uma matéria inobservável.

De qualquer modo, acreditamos que ele cumpriu seu papel no curso, permitindo aos alunos compreenderem os aspectos da natureza da ciência a ele relacionados, o que era , afinal, nossa meta principal.

\subsubsection{Atuação da professora na transposição didática interna.}

Quando se constrói uma proposta de curso a ser aplicado em sala de aula por outra pessoa, sempre se corre o risco de não saber quais aspectos serão modificados. No caso do curso piloto, a professora não tinha formação em história e filosofia da ciência (OC2). Nossas catorze reuniões, os textos estudados por ela seriam suficientes para adquirir tanto conhecimento conceitual e metodológico? Tudo era novo para a professora que aplicaria o curso. Conteúdo histórico e epistemológico, a metodologia de trabalho que envolveu atividades diversificadas e a dinâmica incomum em aulas de física, exigindo leitura e discussão de textos, além de colocar problematizações para os alunos e incentivá-los a 
manifestarem suas opiniões. Buscamos dar o melhor apoio possível no estudo dos textos e na orientação da condução das atividades, mas somente a análise dos dados pode apontar quais aspectos da preparação foram bem sucedidos e quais necessitam de aprimoramento.

A análise do curso indicou que a professora saiu-se muito bem na condução do curso na maioria dos aspectos. Houve alguns momentos em que sua atuação na transposição didática interna modificou um pouco os objetivos de certos conteúdos, indicando aspectos que precisam ser aprimorados na elaboração do material e enfatizados na preparação do professor. Muito embora a formação do professor não seja o foco dessa pesquisa, certamente pertence ao escopo de seus desdobramentos pretendidos.

\subsubsection{Aprofundamento de alguns aspectos epistemológicos}

Um dos obstáculos estruturais enfrentados no curso era o desconhecimento, por parte dos alunos, de conceitos e termos específicos do campo epistemológico, como hipóteses (OS5; OS7; OC4), por exemplo. Buscamos superar esses obstáculos elaborando textos e atividades que usavam tais conceitos e termos, sem discuti-los formalmente, mas construindo uma narrativa que promovesse a sua compreensão. Durante as interações entre os alunos, a professora e o saber, percebemos que nossa opção estratégica havia apresentado bons resultados. Foi possível observar, em vários momentos, os alunos utilizando alguns destes termos de maneira adequada, ainda que uma definição formal não lhes tenha sido apresentada. Vejamos alguns exemplos:

Dia 12/9/2007 - turno 39

Daniel: Ele está levantando uma hipótese (inaudível) observando ele pode levantar hipóteses, eles organizavam (inaudivel)...

Dia 13/9/2007 - turno 147

Clarisse: De certa forma, o júri estava dividido entre as duas teorias, porque algumas pessoas já acreditavam em uma, e como os argumentos foram mostrados, apresentados, foram modificando suas idéias... [...] o júri escolheu a ondulatória, porque de certa forma estavam mais preparados... os argumentos que provariam mais, de certa forma, o que eles estavam dizendo... [...] Por isso nós optamos pela ondulatória, que foi os argumentos mostrados de forma mais clara, que chegou até mesmo a mudar muitas das opiniões. É isso. 
Dia 18/9/2007 - turnos 11 e 13

Professora: [...] eu queria ouvir um pouquinho vocês... o que que mudou na visão de vocês, de ciência, de física... essa história de "provar" isso não é só na física. Eu queria ouvir um pouquinho de vocês, antes da gente entrar no texto.

Tarik: [...] Prova que a teoria deles tem fundamento, eles não provam que é a verdade absoluta, é isso.

Dia 18/9/2007 - turno 41

Professora: Observar o fenômeno da difração... olha as palavras... observar o fenômeno, permite que se conclua que a luz é uma onda?

Aluna: Não, porque é preciso montar experiência, observar o fenômeno, elaborar cálculos matemáticos e formular hipóteses, antes de se concluir alguma coisa.

Essa pequena amostra representa, também, a utilização correta de termos epistemológicos pela maioria dos alunos nas respostas escritas aos questionários. Isso significa que eles compreenderam seu significado no nível pretendido pelo curso piloto.

Apresentamos nesse capítulo a análise dos dados advindos da parte empírica da pesquisa. Descrevemos os desafios enfrentados na elaboração do curso, separando-os em obstáculos superáveis e contornáveis. Apresentamos a análise de três eventos que nos permitiram avaliar o processo de interação entre sujeitos e o Saber a Ensinar. Pontuamos alguns detalhes relevantes do processo e sinalizamos alguns resultados mais gerais.

No próximo capítulo faremos um confronto entre essas discussões, de modo a elaborar algumas conclusões, que possam ser úteis a outros contextos teóricos e empíricos. 


\section{Intermezzo}

A aplicação do curso piloto foi finalizada por um festival cultural, com poesia, história e paródias. Neste intermezzo, reproduzo abaixo a poesia da Alessandra. A autora permitiu sua reprodução e fez questão de ter seu nome mencionado. Nas rimas que ela criou, materializaram-se meus sonhos, os objetivos pedagógicos do curso piloto e a razão da existência de pesquisas em ensino de ciências: o aluno.

\section{A poesia da filosofia}

Alessandra

Eu fico a pensar

dia e noite, noite e dia

quem é que me explica direito

essa tal de FILOSOFIA.

Aristóteles acreditava

que um meio, a visão nos permitia.

Mas, para Empédocles isso não era certo,

certa era a sua teoria.

Tantas questões e na verdade

não sei em quem acreditar:

a teoria certa é a ondulatória de Huygens,

ou a de Newton, a corpuscular?

Arago também ia na dos corpúsculos, explicar, bem que ele tentou.

Mas Fresnel foi tão surpreendente, que até um prêmio ele ganhou.

Agora fico pensando:

por que todos só sabem falar

sobre um tal de éter,

quem consegue me explicar?

Existem tantos filósofos bons.

Professora, um exemplo me dê!

Não! Agora lembrei

Young, gênio desde bebê!
Todos nós temos que ter em nossa plena consciência:

Verdade por caminhos diferentes

são a religião, a filosofia e a ciência.

Um conselho agora deixo

para cada um, de uma só vez:

escolham uma teoria,

e a guardem para vocês.

Quanto a um fenômeno, não basta só observar.

Tem que montar experiência, elaborar cálculos e hipóteses formular.

Agora tenho que encerrar, por isso fico triste.

Um fenômeno só de observar, não podemos provar que existe.

Nunca se esqueçam disto: cada qual com suas razões. A natureza fornece a informação que permite várias interpretações.

Então, tirem suas conclusões!!! 


\title{
Considerações finais
}

\begin{abstract}
Refletir quer dizer ao mesmo tempo:
a) pesar, repesar, deixar descansar, imaginar sob diversos aspectos o problema, a idéia;

b) olhar o seu próprio olhar olhando, refletir-se a si mesmo na reflexão. É preciso alimentar o conhecimento com a reflexão; é preciso alimentar a reflexão com o conhecimento.
\end{abstract}

Edgar Morin

Explorar a utilização da história da ciência no ensino médio mostrou-se um recurso pedagógico favorável e instigador para ensinar sobre a natureza da ciência. Os caminhos da pesquisa detalharam desafios previstos pelo quadro teórico e permitiram desvelar outros mais. Foi possível mapear uma série de obstáculos, propor estratégias para enfrentá-los, aplicar tais estratégias em sala de aula e analisar os dados obtidos. Como resultado obtivemos bons prognósticos para algumas propostas averiguadas e percebemos que algumas soluções necessitaram aprimoramento. A possibilidade de localizar aspectos por aperfeiçoar foi também um importante resultado do processo, tanto para a pesquisa como para orientar a elaboração de material didático e a preparação de outros cursos.

Nosso ponto de partida foi o estabelecimento dos propósitos pedagógicos que pretendíamos atingir com o uso da história da ciência em ambiente escolar. Concorrendo para os objetivos visados, decidimos discutir a natureza da ciência e definimos, assim, a abordagem empírica como o tipo de abordagem a ser adotado para discutir a natureza da ciência. Em seguida, esclarecemos a concepção de natureza da ciência a ser adotada e quais aspectos seriam trabalhados. A seleção desses aspectos foi realizada em função de quatro variáveis: (i) o propósito pedagógico visado; (ii) o tempo didático disponível; (iii) o nível de escolaridade enfocado; (iv) os pré-requisitos dos alunos nos saberes envolvidos na proposta.

Uma vez estabelecidos a meta pedagógica e os aspectos da natureza da ciência a serem tratados, foi possível eleger o tema e os conteúdos históricos adequados para abordá-los. O desafio a seguir foi a seleção dos aspectos a enfatizar ou a omitir de cada conteúdo histórico. As conjecturas feitas sobre o que eleger ou excluir de cada conteúdo indicam outras preocupações além das prescrições historiográficas e necessidades didáticas do contexto em questão, guiando a definição do nível de aprofundamento dos conteúdos 
históricos. Defini-los dependeu também dos objetivos almejados em cada aspecto abordado.

Utilizamos alguns fatores extracientíficos buscando apresentar a ciência como atividade humana em uma perspectiva sociocultural. Entretanto, definir o nível de detalhamento do contexto não científico não foi tarefa elementar, pois receávamos fomentar posições relativistas. A solução proposta para superar esse obstáculo mostrou-se relacionada às estratégias aventadas para contornar a falta de pré-requisitos conceituais dos alunos e também indicou possuir inter-relação com a decisão entre enfatizar aspectos científicos ou enfatizar fatores externos à ciência.

A análise dos dados apontou para algumas estratégias bem-sucedidas e para a necessidade de adotar mais recursos para evitar distorções detectadas. Como vimos na análise do Evento Young, a omissão de uma abordagem mais detalhada dos diferentes caminhos tomados por Young e Fresnel, na construção de uma explicação ondulatória para a natureza da luz, parece ter levado a professora a concluir que Young não sabia matemática. A limitação no tempo didático e a falta de pré-requisitos conceituais dos alunos nos levaram a apresentar as idéias de ambos recorrendo a outras estratégias. Havíamos destacado a capacidade matemática de Fresnel, buscando "equilibrar" a influência de um fator externo à ciência, o apoio recebido de Arago para a elaboração e aceitação de sua teoria da luz. Todavia, essa negociação não foi bem-sucedida. Embora isso não representasse um problema significativo para o objetivo em questão, acarretou uma distorção histórica. Portanto, essa é uma solução a ser aprimorada no texto para o professor e na sua preparação.

Algumas das soluções propostas para contornar a falta de pré-requisitos dos alunos mostraram-se pontualmente eficientes. Isso ficou evidenciado quando os alunos compreenderam a limitação da teoria corpuscular da luz em explicar a difração. A utilização de demonstrações experimentais dos fenômenos ópticos, da animação $D r$. Quantum e a textualização favoreceram a autonomia dos alunos na compreensão de conceitos. Nesses casos, foi fundamental a professora estar ciente das limitações dos alunos para lidar com as carências e os recursos propostos.

Decidir entre enfatizar aspectos científicos ou enfatizar fatores externos à ciência requereu considerar os objetivos pedagógicos pretendidos como um todo e os objetivos de cada conteúdo histórico a ser abordado. O recurso utilizado para lidar com esse conflito foi 
a tomada de decisões pontuais em cada aspecto do conteúdo a ser abordado. Assumimos, primeiramente, não ser possível contextualizar os três episódios históricos estudados sob o ponto de vista historiográfico. Buscamos contornar esse obstáculo comparando teorias e idéias defendidas por pensadores contemporâneos, na tentativa de criar uma perspectiva um pouco mais ampla das teorias discutidas. Para compensar os aspectos externos à ciência mencionados (visando destacar influências de fatores não científicos na elaboração das teorias), buscamos enfatizar características objetivas como a rigorosa matematização, o poder explicativo das teorias e os inúmeros experimentos realizados na construção de conceitos. A complexidade da superação e compensação desses obstáculos adverte para o risco de conseqüências inesperadas. Esse alerta pode ajudar-nos a ampliar o leque de ponderações necessárias na mediação envolvida nas simplificações e omissões.

Os conteúdos selecionados para o curso piloto requeriam a utilização de termos epistemológicos desconhecidos pelos alunos, influenciando dois obstáculos por superar: a definição do nível de aprofundamento de alguns aspectos epistemológicos e a sua posterior formulação discursiva. Decidimos construir textos respeitando a norma culta na correção gramatical, mas buscando adotar uma linguagem coloquial e despretensiosa. As atividades foram planejadas de modo a utilizar tais conceitos, sem defini-los formalmente, mas construindo uma narrativa que promovesse a sua compreensão. Assim, os alunos interagiam com exemplos históricos de modo a favorecer o entendimento dos conceitos envolvidos nos termos epistemológicos. Os dados obtidos e discutidos no capítulo 4 mostraram a adequação da estratégia ante os resultados satisfatórios apresentados.

A opção pelo uso de fontes primárias foi feita considerando-se três fatores: (i) a falta de domínio da professora do contexto histórico e/ou "científico" dos conteúdos a serem tratados; (ii) utilizar as fontes primárias do período mais conhecido pela autora dos textos para os alunos, buscando guiar a leitura e amenizar interpretações anacrônicas; (iii) utilizar trechos pequenos e inteligíveis aos alunos. Os dados não revelaram problemas tampouco dificuldades com as breves citações de Huygens e Newton utilizadas.

Tratar diacronicamente conteúdos da história da ciência de difícil compreensão na atualidade requereu uma combinação de estratégias. Simplificamos, tanto quanto possível, a idéia do ente inobservável enfocado (o éter), omitindo aspectos dispensáveis para os objetivos do curso. Buscamos apresentar vários pensadores de diferentes períodos utilizando o éter em suas teorias, de modo a enfatizar a adequação de sua concepção ao 
período. Além disso, destacamos essa visão na preparação da professora, discutindo exemplos de visões anacrônicas e como confrontá-las. Esse obstáculo inclui também a dificuldade de promover "rapidamente" o entendimento diacrônico de diferentes concepções de ciência e pensadores de distintas épocas, a validade de seus critérios, crenças e valores. A falta dessa compreensão parece gerar diversos tipos de anacronismo e novamente buscamos enfatizá-las na preparação da professora, simulando perguntas, comentários e discutindo possíveis modos de problematizá-los. Entretanto, obtivemos resultados mais significativos ao permitir aos alunos vivenciar aspectos da dinâmica da construção da ciência na atividade do "debate" promovido em classe. O confronto entre os alunos e a necessidade de construir argumentos para defender suas idéias, limitando-se aos conhecimentos válidos no período preestabelecido, parecem ter sido decisivos para os alunos adquirirem um entendimento mais diacrônico da história da ciência.

As concepções ingênuas sobre história e epistemologia da ciência presentes no cotidiano dos alunos, veiculadas pela mídia e perpetuadas no ensino de ciências, são um obstáculo que se manifesta de diferentes modos. Uma perspectiva dessas concepções previstas e manifestadas durante o curso refere-se à possível concepção prévia dos estudantes e professores sobrevalorizando a capacidade da ciência atual em resolver todos os problemas. Não é possível modificar significativamente tais concepções, por ultrapassarem os limites do curso, sendo, assim, necessário contornar tais obstáculos. Foram desenvolvidas provocações para motivar os alunos a questionar suas antigas crenças e, ao mesmo tempo, introduzir a visão pretendida. Tais recursos, conduzidos pela atuação da professora na transposição didática interna, mostraram-se adequados para contribuir com os propósitos pedagógicos almejados. Percebemos que os obstáculos discutidos acima dizem respeito a diferentes manifestações de anacronismo. Pensamos que alguns deles podem ser superados, mas algumas visões, provavelmente, serão apenas contornadas.

Isso nos remete a outro obstáculo que requer estratégias para contorná-lo: a falta de preparação do professor. Algumas das estratégias utilizadas no apoio à professora apresentaram bons resultados e outras mostraram pontos que devem ser aperfeiçoados. A preparação realizada com a professora mostrou-se bem-sucedida sob vários aspectos e apontou para a necessidade de aperfeiçoar recursos e inserir algumas orientações adicionais. Os textos da bibliografia foram discutidos com a professora de modo a esclarecer suas dúvidas e apresentar exemplos. Os pontos mais críticos foram destacados, 
como, por exemplo, as concepções ingênuas e anacrônicas possíveis de ser manifestadas pelos alunos. O texto elaborado para a professora trazia, de modo geral, mais detalhes e mais exemplos históricos para a visão da natureza da ciência a ser tratada. Os slides preparados serviram para auxiliá-la nas aulas e cada apresentação foi discutida minuciosamente. Alguns aspectos da preparação mostraram-se insuficientes, como evidenciaram algumas respostas surpreendentes dos alunos não exploradas. O tempo e os recursos utilizados para tratar a linha do tempo foram insuficientes, como atestaram alguns enganos da professora ao apresentá-la. O texto do terceiro episódio para o professor deveria ter sido mais aprofundado (Evento Young). Os textos para o professor voltados aos episódios I e II exploram mais exemplos históricos do que aquele do episódio III. Percebemos melhores resultados na autonomia da professora em abordá-los em classe.

\section{A inadequação dos trabalhos especializados em história da ciência ao ensino} médio requereu a elaboração dos textos do Saber a Ensinar. As conjecturas para a construção dessa textualização foram discutidas sob vários aspectos e em diversos momentos desta tese, e mencionamos sinteticamente aqui as estratégias propostas na sua elaboração. Para tratar o estudo de Newton sobre o "fenômeno das cores", recorremos à sua demonstração experimental para que os alunos o visualizassem. Elaboramos a apresentação de slides buscando enfatizar as etapas seguidas no estudo desse fenômeno, e tentando descrever as proporções matemáticas e outros detalhes omitidos pelos textos especializados. Além disso, buscamos retomar essas idéias apresentadas no texto escrito para os alunos. Nosso propósito era destacar a formulação de hipóteses na elaboração da teoria das cores para contrapor à crença no experimetum crucis. Consideramos que nosso objetivo foi atendido e não percebemos nenhuma dificuldade ou distorção.

A bem conhecida falta de hábito de leitura entre os estudantes do ensino médio nos fez ponderar sobre a quantidade da informação na forma de textos adequada a utilizarmos. Assumimos o risco de fornecer uma quantidade significativa de textos para o tempo didático disponível e sugerimos para a professora realizar sua leitura junto com os alunos, problematizando os aspectos relevantes. A estratégia mostrou-se eficiente e a leitura dos textos não apresentou problemas ou resistência por parte dos alunos. $\mathrm{O}$ estilo coloquial adotado provavelmente pode ter contribuído para sua aceitação.

A proposta para conciliar extensão e profundidade foi recorrer ao apoio da linha do tempo. Os três episódios históricos foram trabalhados mediante recortes bem estabelecidos, 
mas procuramos um modo de permitir ao aluno uma visão ampla do processo histórico. Pretendíamos enfocar diacronicamente um conteúdo da história da ciência bem delimitado e nossa hipótese era que a linha do tempo permitiria sua contextualização apontando aspectos culturais envolvidos. Conforme discutimos na seção 4.3.2, não foi possível validar nossa hipótese, mas permanece aqui como uma sugestão para investigações futuras.

A diversidade de recursos pedagógicos adotados foi uma estratégia relevante para a apropriação pelos alunos das problemáticas propostas e para o bom êxito do curso piloto. Embora haja na literatura grande ênfase sobre a escassez de materiais adequados abordando a história da ciência, percebemos existirem, além das necessidades historiográficas, outras exigências relacionadas ao desenvolvimento de tais materiais. Além dos aspectos do conteúdo selecionados e o estilo de textualização adotado, o uso do conjunto de distintas atividades didáticas mostrou-se significativo para engajar os alunos nos temas propostos. Com as distintas estratégias pedagógicas e a metodologia problematizadora adotada, a pesquisadora desejava tornar o aluno o protagonista da relação didática. Os resultados das análises de tais aspectos sugerem que os propósitos foram atingidos.

Uma estratégia adotada no planejamento do curso que apresentou bons resultados foi repetir o mesmo objetivo pedagógico e o mesmo aspecto da natureza da ciência em distintas atividades pedagógicas e em diferentes conteúdos históricos. Ela permitia ao aluno ter contato com a problemática levantada mais de uma vez e refletir sobre ela mediante diferentes contextos da história da ciência. Essa diversidade de recursos favoreceu a reflexão, a vivência de conflitos e o envolvimento dos alunos com os temas propostos.

Desde as conjecturas teóricas, o percurso descrito ao longo da tese fornece um cenário dos obstáculos enfrentados e das soluções propostas. A síntese de desafios e de tais propostas aventadas, aplicadas e analisadas não deve ser entendida como receita ou regras rígidas para utilizar a história da ciência na educação científica. É importante considerar toda a exploração vivenciada para sistematizá-la. Essa síntese não é a única opção, naturalmente, mas é uma possibilidade já trilhada, experimentada, avaliada.

Esse percurso da pesquisa acabou por revelar inúmeros desdobramentos possíveis, mas a coerência necessária ao recorte adotado impôs escolhas e nos fez abdicar de explorálos. Dentre eles ficou clara a necessidade de investigar melhor o papel desempenhado pela 
professora, que se mostrou fundamental na implementação da proposta. A teoria da transposição didática já havia nos permitido atribuir-lhe função de destaque no processo, mas a análise dos dados fortaleceu nossa convicção sobre isso e pela necessidade de investigações que tivessem nela o foco principal.

A atuação da professora na transposição didática interna gerou informações relevantes para compreender as necessidades presentes na formação inicial e continuada de professores. Em pouco tempo ela se apropriou do tema, do conteúdo histórico e epistemológico e mostrou-se satisfeita com os resultados alcançados durante o curso. Ela atuou adequadamente na maioria das situações previstas, problematizando as concepções ultrapassadas enfatizadas pela mídia; discutindo os conflitos com a visão popular sobre a natureza da ciência; enfatizando os problemas com materiais obtidos da internet etc. A professora também revelou habilidade na condução da maioria das situações inesperadas, exceto por alguns problemas levantados pelos alunos para os quais ela não havia sido preparada. Algumas dessas situações imprevistas foram discutidas e puderam ser retomadas, como a idéia de "provas na ciência" manifestada na apresentação do episódio II. Orientamos a professora para retomá-la e problematizá-la nas aulas seguintes até que percebêssemos a compreensão adequada por parte dos alunos.

Caberia retomar como questão de investigação os condicionantes que fazem do professor um agente com autonomia relativa para lidar com situações de inovação envolvendo o uso da história da ciência. Este ponto encontra ressonância com problemáticas recentes tratadas na área e nas preocupações do grupo de pesquisa do qual faço parte (Nupic-FEUSP).

Na perspectiva da aprendizagem, seria interessante acompanhar o desempenho dos estudantes ante outros conteúdos da história da ciência que implicassem considerações sobre a natureza da ciência. A concepção ingênua e estereotipada demonstrada por alguns alunos durante as primeiras aulas gravadas se mantém em outros conteúdos históricos? Isso poderia lançar luzes sobre a seleção dos episódios a ser tratados com o objetivo de abordar a natureza da ciência?

Finalmente, interessa-nos aprofundar a autonomia do material didático produzido na forma do curso piloto em outros contextos. Embora a professora escolhida para ministrar o curso não tivesse características muito distintas de uma boa professora de física 
do ensino médio, caberia questionar os resultados do curso com outros docentes. $\mathrm{Na}$ mesma direção, seria importante saber como reagiria outra classe de alunos.

Acreditamos que o passo dado nesta pesquisa torna a resposta a essas e outras questões mais próximas.

Os resultados obtidos por esta pesquisa indicam algumas possibilidades de generalizações, para uma perspectiva mais ampla da utilização da história e filosofia da ciência na educação científica. Ao olharmos retrospectivamente para todo o processo, identificamos algumas etapas norteadoras do caminho percorrido, capazes de servir como guias para casos semelhantes. Tais guias podem ser entendidos como parâmetros ou pontos de partida para outras pesquisas envolvidas com os usos da história e filosofia da ciência na educação científica.

Parece importante inicialmente destacar a perspectiva de análise adotada. Os parâmetros se apresentam na forma genérica de obstáculos e propostas de enfrentamento abordados e analisados teórica e empiricamente, como etapas a serem percorridas na direção da sala de aula. Essas etapas não seguem sempre necessariamente uma sequiência ordenada, pois algumas delas ocorrem simultaneamente e exigem tomadas de decisões conjuntamente também. Certos desafios se sobrepõem e cada decisão pode impactar nas demais soluções adotadas. Sem a pretensão de se tornarem "receitas de sucesso" ou regras a serem seguidas, os pontos a seguir parecem constituir indicadores capazes de guiar um processo de transposição didática para o uso da história da ciência.

As etapas e sugestões serão apresentadas sinteticamente, pois foram discutidas em detalhes várias vezes ao longo desta tese.

1. A história da ciência configura-se um recurso pedagógico que permite atingir diferentes objetivos educacionais, assim, o primeiro passo necessário é estabelecer o $(s)$ propósito(s) pedagógico(s) objetivado(s).

2. Optar por discutir a natureza da ciência requer esclarecer qual concepção de ciência será adotada e os aspectos epistemológicos que serão trabalhados. Sua seleção depende de características de cada contexto, por exemplo: (i) o propósito pedagógico visado; (ii) o tempo didático disponível; (iii) o nível de escolaridade enfocado; (iv) os prérequisitos dos alunos nos saberes envolvidos na proposta. 
O propósito pedagógico almejado e os aspectos da natureza da ciência visados permitem a eleição do tema e dos conteúdos históricos mais adequados. É preciso identificar momentos da história da ciência que possuam elementos para exemplificar os aspectos epistemológicos pretendidos. Vários dos desafios pontuados a seguir apresentam detalhes e requisitos para auxiliar essa seleção. Além disso, é importante tais conteúdos permitirem o desenvolvimento de atividades favoráveis à participação ativa e, de certo modo, autônoma dos estudantes.

a) O primeiro desafio a enfrentar é a seleção dos aspectos a enfatizar ou a omitir de cada conteúdo histórico. Diversas variáveis influenciam nessas escolhas e elas, por sua vez, afetam soluções propostas para superar ou contornar outros obstáculos. As recomendações historiográficas devem ser levadas em conta, por exemplo, no sentido de evitar distorções advindas de relatos excessivamente superficiais. Por outro lado, não é possível tratar um recorte histórico e discuti-lo em seus detalhes como recomendável em trabalhos especializados.

Importa relembrar que o enfrentamento dos desafios envolvidos na seleção dos conteúdos para a elaboração do Saber a Ensinar deve considerar as distintas funções sociais desempenhadas pelos saberes voltados ao especialista e aqueles adequados ao estudante do ensino médio. Além das prescrições historiográficas e necessidades didáticas do contexto em questão, a seleção dos conteúdos requer ter claro o objetivo almejado com cada aspecto abordado.

b) A seguir, é importante confrontar o aspecto omitido com os demais objetivos. Por exemplo, quando se decide excluir a abordagem matemática na formulação de determinado conceito, deve-se verificar se tal omissão não será prejudicial para os outros aspectos abordados. Inserir informações sem esclarecê-las adequadamente pode, também, incorrer em distorções históricas ou mesmo epistemológicas. Portanto, a mediação entre selecionar e omitir pode ser auxiliada pelo confronto de cada aspecto com as partes e com o todo.

c) Discutir a ciência como atividade humana em uma perspectiva sociocultural implica definir o nível de detalhamento do contexto não científico a ser adotado, por exemplo, apresentando fatores extracientíficos que teriam influenciado os conteúdos da ciência. Esse obstáculo pode ser superado, pois, em função da mensagem pretendida, é possível selecionar elementos do contexto de uma época para exemplificá-la. Contudo, 
lidar com o contexto não-científico pode configurar-se um obstáculo mais complexo, como a decisão entre enfatizar aspectos científicos ou enfatizar fatores externos à ciência.

d) Destacar fatores externos à ciência permite tanto criticar uma visão puramente empirico-indutivista como contextualizar o desenvolvimento de conceitos científicos. Sob tal perspectiva, sobrevalorizar a influência do contexto na construção da ciência envolve riscos, podendo levar a posições relativistas extremas. Seria desejável contrabalançar ambos os enfoques buscando o equilíbrio entre aspectos científicos e fatores socioculturais, o que exige uma avaliação minuciosa de vários aspectos envolvidos. Torna-se importante ampliar o leque de ponderações necessárias na mediação envolvida nas simplificações e omissões, tanto de aspectos científicos como não-científicos. Um caminho pode ser separar os objetivos visados com cada aspecto do conteúdo e confrontar tanto os aspectos científicos como os extracientíficos com cada um deles, e também com o objetivo geral da proposta.

3. A utilização da história e filosofia da ciência no ensino médio poderá enfrentar, de modo geral, a falta de pré-requisitos dos alunos em relação ao conhecimento matemático, físico, histórico, epistemológico ou filosófico. Esse é um obstáculo a ser contornado na maioria das vezes, a menos que haja tempo didático disponível para trabalhá-los. Mediante alguns cuidados e precavendo-se na medida do possível para risco de conseqüências inesperadas, utilizar um conjunto de estratégias pode compensar a falta de certos conhecimentos dos conteúdos físicos e matemáticos. Por exemplo, buscando compensar a ausência de domínio de saberes matemáticos, pode-se recorrer a várias atividades conjuntamente. Aliar a demonstração de fenômenos físicos ou a realização de experimentos, animações em vídeo, figuras geométricas e imagens gráficas pode auxiliar no entendimento superficial de um fenômeno físico, quando esse nível de compreensão for suficiente para os objetivos específicos pretendidos.

É importante, todavia, destacar que esses recursos podem ser úteis apenas para contornar alguns obstáculos. Eles constituem, em conjunto, uma solução pontual, perene, aparentemente válida quando os principais objetivos pedagógicos visados não estão em jogo. Tal solução pode, eventualmente, auxiliar com conteúdos de apoio, mas não seria adequada para enfocar os principais conceitos pretendidos. Seria interessante ponderar essa proposta no confronto com as partes e com o todo, pois algumas soluções pontuais podem comprometer outro aspecto da estrutura que se busca construir. 
4. Uma proposta visando discutir a natureza da ciência no ensino médio provavelmente requererá o entendimento de conceitos como hipóteses, teorias, argumento etc., e não nos parece adequado admitir como pressuposto seu domínio pelos alunos. A definição do nível de aprofundamento de alguns aspectos epistemológicos e a sua posterior formulação discursiva envolvem o conhecimento de novos conteúdos e seus respectivos vocabulários. Alguns desses conceitos e vocabulários podem ser compreendidos pelos alunos sem serem formalmente definidos. Utilizá-los corretamente nas atividades, nas apresentações, nas explicações do professor, em conjunto com a formulação discursiva do texto, poderá auxiliar o aluno compreendê-los.

5. Tão tentadora quanto perigosa, aos nossos olhos, é a opção pelo uso de fontes primárias em materiais didáticos voltados ao ensino médio. Idealmente, seria importante a interação do aluno com os originais ser acompanhada por alguém que conhecesse minimamente o contexto de trabalho do autor para conduzir uma interpretação diacrônica. Entretanto, não se pode contar com situações ideais. Desse modo, o elaborador de um material didático, ou qualquer tipo de proposta para o uso da história e filosofia da ciência no ensino, deve ficar atento para essa questão. Parece-nos interessante os excertos de fontes primárias virem acompanhados por explicações, auxiliando sua interpretação e atentando para possíveis preconceitos com relação aos vocabulários, conceitos da ciência e valores de outras épocas. Além disso, é recomendável selecionar trechos inteligíveis ao aluno e capazes de despertar seu interesse, e não serem demasiado longos do ponto de vista do nível de escolaridade enfocado. $\mathrm{O}$ autor deve estar seguro com relação à interpretação dos aspectos tratados e a possibilidade de torná-los compreensíveis tanto para os estudantes como para o professor que vão utilizá-los.

6. Tratar diacronicamente conteúdos da história da ciência de difícil compreensão na atualidade requer lidar com uma das facetas do anacronismo: considerar como ridículos ou estranhos certos conceitos, pressupostos e metodologias importantes em outros momentos da história da ciência, mas descartados da ciência atual. Nesse sentido, outro obstáculo a enfrentar é compreender adequadamente diferentes concepções de ciência e pensadores de distintas épocas, a validade de seus critérios, convicções e valores. $\mathrm{O}$ anacronismo manifesta-se ainda como a crença sobre o fracasso das teorias do passado ser justificado pelo atraso científico daqueles períodos. A dificuldade em compreender 
diacronicamente a história da ciência perpetua as visões equivocadas sobre a natureza da ciência que eventualmente se objetiva modificar.

Algumas estratégias podem favorecer o enfrentamento desses desafios. Apresentar vários pensadores trabalhando com as mesmas perspectivas metodológicas pode contribuir para amenizar, em parte, tais preconceitos. Seria interessante, também, estabelecer uma relação entre exemplos de resultados significativos da história da ciência com concepções consideradas "estranhas" pelos alunos. O desenvolvimento da Gravitação Universal ter sido influenciada por estudos alquímicos e teológicos de Isaac Newton se configura como um exemplo disso. Um apoio fundamental seria também preparar o professor para identificar, lidar e problematizar possíveis manifestação anacrônicas. Sendo assim o material didático poderia incluir orientações nesse sentido.

Contudo, a estratégia que tende a apresentar melhores resultados é permitir aos estudantes vivenciar aspectos da dinâmica da construção da ciência por meio de atividades, como um debate entre teorias rivais. O contato livre entre os pares, a construção de argumentos restritos aos recursos válidos para a época enfocada pode contribuir sobremaneira para uma compreensão diacrônica da história da ciência.

7. Além do anacronismo, as concepções ingênuas sobre história e epistemologia da ciência representam um obstáculo a contornar quando se objetiva tratar a natureza da ciência no ensino. Uma visão puramente empirista da ciência, a idéia das provas irrefutáveis, dos gênios infalíveis, por exemplo, estão presentes no cotidiano dos alunos, são veiculadas pela mídia e perpetuadas no ensino de ciências. Esse obstáculo manifesta-se também como uma possível concepção prévia dos estudantes e professores sobrevalorizando a capacidade da ciência atual em resolver todos os problemas.

Criticar essas concepções significa defender um enfoque distinto da visão dos alunos e demais pessoas da sua convivência, diferente das mensagens continuamente passadas pela mídia e conflitante com aquela trazida pelos materiais didáticos mais tradicionais. Admitimos como pressuposto a necessidade de envolver o aluno, quando apresentamos um novo conteúdo, para seu efetivo aprendizado. Propor uma concepção não apenas nova, mas conflitante com idéias arraigadas no seu repertório, requer vivenciar algum tipo de conflito ou problematização com as novas concepções. Uma possível solução é articular provocações para motivar os alunos a questionar as antigas crenças e, ao mesmo tempo, introduzir estratégias apresentando a visão pretendida. Lidar com esse 
obstáculo também impõe preparar o professor, discutindo vários exemplos e advertindo-o para tratar concepções inesperadas.

8. A atuação do professor na transposição didática interna é de fato uma variável fundamental no uso da história e filosofia da ciência no ensino. Muitas das soluções propostas acima para enfrentar os desafios envolvem lidar com a falta de formação do professor nesses saberes. É possível contornar em parte essa dificuldade recorrendo a estratégias pedagógicas presentes nos materiais de ensino, mas esse obstáculo não permite superação em pouco tempo. No caso de haver a possibilidade de preparar o professor que trabalhará com uma proposta específica, é importante discutir em detalhes todos os obstáculos possíveis de ser previstos. Caso contrário, o material didático pode contribuir para orientar algumas ações. Desde as diversas manifestações de anacronismo, de concepções ingênuas, das idéias que se busca modificar e estão presentes no repertório do aluno e seu entorno social, até as possíveis dúvidas que surgirem sobre o conteúdo que se quer trabalhar. Algumas orientações podem ser dadas em detalhes no planejamento de uma intervenção pontual ou nas propostas de cursos mais longos. Por exemplo, discutir em maior profundidade e quantidade de exemplos do período histórico a ser trabalhado em relação ao que será tratado com os alunos. No caso da preparação de material didático, vale relembrar os diferentes pressupostos com relação ao Saber Sábio e o Saber a Ensinar.

9. Os conteúdos da história da ciência são, em geral, sistematizados na forma de textos. Isso pode significar um desafio, pois muitos estudantes não têm o hábito de leitura. Decidir a quantidade da informação na forma de textos adequada depende de características intrínsecas a cada contexto envolvido, em particular a correta avaliação do tempo didático disponível. Há certas estratégias que podem auxiliar na utilização dos textos no nível do ensino médio. Adotar uma linguagem coloquial, de fácil compreensão para os alunos, pode minimizar possíveis resistências. Optar por tratar de aspectos que despertem a curiosidade dessa faixa etária configura-se um recurso válido, desde que não se construam narrativas fantasiosas, whigs ou hagiográficas.

10. Adotar uma abordagem historiograficamente adequada da história da ciência, para produzir o recorte dos temas que serão tratados com os alunos, pode ocasionar uma perda da noção de temporalidade. O estudante do ensino médio pode ter dificuldade em localizar o episódio enfocado em uma perspectiva histórica. Desse modo, seria desejável conciliar extensão e profundidade. Uma sugestão para lidar com esse desafio é utilizar a 
linha do tempo como a realizada no curso piloto. No entanto, outras alternativas metodológicas podem vir a gerar bons resultados.

11. A elaboração de textos e a criação de atividades para tratar a história e a filosofia da ciência no ambiente escolar requerem mais que certo conhecimento dessas duas áreas. Os textos e as atividades devem ser capazes de promover a interação dos alunos com a problemática tratada. Não basta o texto ser absolutamente correto do ponto de vista historiográfico, se ele não "funciona" na sala de aula. Envolver os alunos nos temas propostos de modo a se apropriar dos problemas não é tarefa elementar. É necessário ter conhecimentos didáticos e certa familiaridade com metodologias educacionais para amparar a construção de propostas para o ensino de ciências. A preparação de cursos em diferentes contextos requer conhecimentos histórico-filosóficos e, também, pedagógicos.

12. Uma estratégia pedagógica que pode apresentar bons resultados é a problematização de cada mensagem acerca da natureza da ciência pretendida em distintas atividades pedagógicas e em diferentes conteúdos históricos. Permitir ao estudante confrontar-se com um mesmo conteúdo por meio de diferentes provocações e mediante situações didáticas diversas favorece a reflexão e o amadurecimento da relação entre o aluno e o saber. Acreditamos que essa oportunidade pode promover um aprendizado mais efetivo.

Os desafios descritos acima e algumas propostas para enfrentá-los não se configuram regras prescritivas, e nem poderiam, dada a complexidade do processo de ensino-aprendizagem e dos vários campos do saber envolvidos. Buscamos relatar nosso percurso e destacar alguns resultados, tentando generalizá-los de modo a poderem contribuir para pesquisas que utilizem a história da ciência para transformar a natureza da ciência em saber escolar.

O cume de uma montanha pode ser atingido de diversos modos. Apresentamos aqui o relato das trilhas que abrimos, das pontes que construímos, dos tropeços e dos arranhões com os quais, finalmente, atingimos nosso objetivo. 


\section{Referências bibliográficas}

ABD-EL-KHALICK, F.; LEDERMAN, N. The influence of history of science courses on students' views of nature of science. Journal of Research in Science Teaching 37 (10): 1057-1095, 2000.

ALFONSO-GOLDFARB, A. M. O que é História da Ciência. São Paulo: Brasiliense, 1994.

ALLCHIN, D. How not to teach history of science. In: FINLEY, F.; ALLCHIN, D.; RHEEDS, D.; FIELD, S. (Eds.), Proceedings, Third International History, Philosophy and Science Teaching Conference, vol. 1, University of Minnesota, Minneapolis, MN, 1995, p. 13-22.

Pseudohistoinry and pseudoscience. Science \& Education 13: 179-195, 2004. 111,2006

Why respect for history - and historical error - matters. Science \& Education 15 (1): 91 -

ALMEIDA, Maria Ângela Vasconcelos de. A nova didática das ciências e o saber docente dos professores de química. Tese de Doutorado. Universidade Federal de Pernambuco. Ceará, 2006.

ALVES-FILHO, José Pinho. Atividades experimentais: do método à prática construtivista. Tese de Doutorado. Florianópolis, UFSC, 2000.

ANHORN, Carmen Teresa Gabriel. Um objeto de ensino chamado História; A disciplina de História nas tramas da didatização. Tese de Doutorado. Rio de Janeiro, PUC-RIO, 2003.

Nas tramas da didatização de uma disciplina escolar: entre histórias a ensinar e histórias ensinadas. Anais da 27a. Reunião da ANPED. Caxambu, 2004. Disponível em: <http://www.anped.org.br/reunioes/27/ gt04/t041.pdf>. Acesso em: 12 ago. 2008.

ASTOLFI, Jean-Pierre; DEVELAY, Michel. A didática das ciências. Campinas: Papirus, 1995.

BACHELARD, G. A formação do espírito científico: contribuição para uma psicanálise do conhecimento. Tradução Estela dos Santos Abreu. Rio de Janeiro: Contraponto, 1996.

BATISTA, I. L. Reconstruções histórico-filosóficas e a pesquisa em educação científica e matemática. In: NARDI, R. (Org.) A pesquisa em ensino de ciências no Brasil: alguns recortes. São Paulo: Escrituras Editora, 2007, p. 257-272.

BELL, Randy; ABD-EL-KHALICK, Fouad; LEDERMAN, Norman G.; MCCOMAS, William F.; MATTHEWS, Michael R. The nature of science and science education: a bibliography. Science \& Education 10 (1/2): 187-204, 2001.

BERNARDO, L. M. Concepções sobre a natureza da luz no século XVIII em Portugal. Revista da SBHC 19: 3-12, 1998.

BIZZO, N. M. V. Ensino de evolução e história do darwinismo. Tese de Doutorado. São Paulo, Faculdade de Educação, USP, 1991. (p. 149-161).

BOSS, Valentin. Newton and Russia, the early influence, 1698-1796. Cambridge: Harvard University Press, 1972.

BRASIL. Parâmetros curriculares nacionais: ensino médio. Brasília: MEC; SEMTEC, 2002a.

Orientações educacionais complementares aos parâmetros curriculares nacionais: ensino médio. Ciências da Natureza, Matemática e suas Tecnologias. Brasília: MEC; SEMTEC, 2002b.

BROCKINGTON, Guilherme. A realidade escondida: a dualidade onda-partícula para alunos do Ensino Médio. Dissertação de Mestrado. São Paulo, Instituto de Física e Faculdade de Educação, USP, 2005.

BRUSH, S. G. Comments on "On the distortion of the history of science in science education". Science Education 63: 277-278, 1979. 
. History of science and science education. Scientific Literacy Papers: 75-85, 1987; Interchange 20 (2): 60-70, 1989.

BUCHWALD, J. Z. The battle between Arago and Biot over Fresnel. Journal of Physics 20: 109117, 1989a.

The rise of the wave theory of light. Optical theory and experiment in the early Nineteenth Century. Chicago / London, The University of Chicago Press, 1989b.

CAETANO, H.; NETO, A. J. Natureza e ensino da ciência: investigando as concepções de ciência dos professores. Enseñanza de las Ciências, Número Extra: 1-5, 2005.

CANGUILHEM, G. Ideologia e Racionalidade nas Ciências da Vida. Trad. Emília Piedade. Lisboa: Edições 70, 1977.

CANTOR, G. N.; HODGE, M. J. S. (Eds.). Conceptions of ether. Studies in the history of ether theories. 1740-1900. Cambridge/ London/ New York: Cambridge University Press, 1981.

CARVALHO, A. M. P. Uma metodologia de pesquisa para estudar os processos de ensino e aprendizagem em salas de aula. In: SANTOS, F.M.T.; GRECA, I.M. (Orgs.) A pesquisa em ensino de ciências no Brasil e suas metodologias. Unijuí: Ed. Unijuí, 2006, pp.13-48.

A pesquisa em sala de aula e a formação de professores. In: NARDI, R. (Org.) A pesquisa em ensino de ciências no Brasil: alguns recortes. São Paulo: Escrituras Editora, 2007, p. 193-218.

CARVALHO, A.M.P.; CASTRO, R.S. de. La historia de la ciencia como herramienta para la enseñanza de física secundaria: un ejemplo en calor y temperatura. Enseñanza de las Ciencias 10 (3): 289-294, 1992.

CARVALHO, A.M.P.; GONÇALVES, M.E.R. Formação continuada de professores: o vídeo como tecnologia facilitadora da reflexão. São Paulo. Cadernos de Pesquisa, 111, p.71-94, dezembro, 2000.

CASTRO, R.S.; CARVALHO, A.M.P. de. História da ciência: investigando como usá-la num curso de segundo grau. Caderno Catarinense de Ensino de Física 9 (3): 225-237, dez. 1992.

CHALMERS, A. F. O que é ciência afinal? Trad. Raul Fiker. São Paulo: Brasiliense, 1993.

CHEN, Suffen. Development of an instrument to assess views on nature of science and attitudes toward teaching science. Science Education 90: 803-819, 2006.

CHEVALLARD, Yves. La transposición didáctica: del saber sabio al saber enseñado. Buenos Aires: Aique, 1991.

CHAVALLARD, Yves; JOSHUA, Marie-Alberte. Un exemple d'analyse de la transposition didactique - La notion de distance (1982). In: CHEVALLARD, Y. La Transposition Didactique du savoir savant au savoir enseigné. Grenoble: La Pensée Sauvage, 1985.

COHEN, Bernard; WESTFALL, Richard S. Newton: textos, antecedentes, comentários. Trad. Vera Ribeiro. Rio de Janeiro: Contraponto; EDUERJ, 2002.

COHEN, M.R.; DRABKIN, I.E. (Eds.). A source book in the Greek science. Cambridge: Harvard University Press, 1958.

CONCARI, S.B. Las teorías y modelos en la explicación científica: implicancias para la enseñanza de las ciencias. Ciência \& Educação 7: 85-94, 2001.

CUPANI, A.; PIETROCOLA, M. A relevância da epistemologia de Mario Bunge para o ensino de ciências. Caderno Brasileiro de Ensino de Física 19 (número especial): 100-125, jun. 2002.

DEBUS, Allen G. A ciência e as humanidades: a função renovadora da indagação histórica. Revista da Sociedade Brasileira de História da Ciência 5: 3-13, 1991. 
El Hombre y la Natura en el Renacimiento. Trad. S. Rendón. 2. ed. México: Fondo de Cultura Económica, 1996.

DOBBS, Beth J. T. The Janus faces of genius - the role of alchemy in Newton's thought. Cambridge/New York: Cambridge University Press, 1991.

The Foundations of Newton's Alchemy or “The Hunting of the Greene Lyon”. 2a. ed. Cambridge; London: Cambridge University Press, 1975, Reprinted: 1984.

DONOVAN, A. et. al. The history of science in undergraduate education - three approaches. Scan: a data bank of scientific research for science faculty in schools and colleges 2 (2): 36-41, 1978.

DUIT, R. The constructivist view in science education: what is to offer and what should not be expected from it. Investigações em Ensino de Ciências 1 (1): 40-75, 1996.

EL HANI, Charbel N. Notas sobre o ensino de história e filosofia da ciência na educação científica de nível superior. In: SILVA, C. C. (Org.) Estudos de história e filosofia das ciências. Subsídios para aplicação no Ensino. São Paulo, Ed. Livraria da Física, 2006, p. 3-21.

ERICSON, F. Qualitative research methods for science education. In: FRASER, B.J. e TOBIN, K.G. (Orgs.), International Handbook of Science Education, Part One, Kluwer Academic Publishers, 1998.

FIELD, J.V.; JAMES, F.A.J.L. (Orgs.). Renaissance and revolution: humanists, scholars, craftsmen and natural philosophers in early modern Europe. Cambridge: Cambridge University Press, 1993.

FLAUVEL, J.; FLOOD, R.; SHORTLAND, M.; WILSON, R. Let Newton be! Oxford/ New York: Oxford University Press, 1988.

FORATO, Thaís C. M. A Filosofia Mística e a Doutrina Newtoniana: uma discussão historiográfica. ALEXANDRIA Revista de Educação em Ciência e Tecnologia 1 (3): 29-53, 2008.

As profecias bíblicas e a existência de Deus. In: SILVA, Cibelle C. (Org.) Estudos de história e filosofia das ciências. Subsídios para aplicação no Ensino. São Paulo, Ed. Livraria da Física, 2006.

O método newtoniano para a interpretação das profecias bíblicas de João e Daniel na obra: "Observations upon the prophecies of Daniel and the Apocalypse of St. John". Dissertação de Mestrado. - São Paulo, Pontifícia Universidade Católica de São Paulo, 2003.

FORATO, Thaís C. M.; MOURA, Breno A.; PRESTES, Maria Elice B. Bibliografia sobre a utilização da história e filosofia da ciência no ensino de ciências e biologia. Boletim de História e Filosofia da Biologia 2 (3), 2008. Disponível em: http://www.abfhib.org/Boletim/Boletim- HFB02-n3-Set-2008.htm. Acesso em: 4/11/2008.

; PIETROCOLA, M. O arrastamento parcial do éter de Fresnel como explicação científica. In: NARDI, R. e BORGES, O. (orgs.) Atas do V Encontro Nacional Pesquisa em Educação em Ciências - ABRAPEC, Bauru, 2005. CD-ROM.

FOX, R. The rise and fall of laplacian physics. History studies in the physical science 4: 89-136, 1975.

FINOCCHIARO, M.A. et. al. A symposium on the use of the history of science in the science curriculum. Journal of College Science Teaching 10 (1): 14-33, 1980.

FRESNEL, A. Lettre d'Augustin Fresnel à François Arago sur l'influence du mouvement terrestre dans quelques phénomènes d'optique. Annales de Chimie et de Physique 9: 57-66; 286, 1818.

Oeuvres Complètes d'Augustin Fresnel. Henri de Senarmont, Émile Verdet et Léonor Fresnel, (Eds). Vol. 2, Paris, Imprimiérie Impériale, 1868. 3 vols. 
GABRIEL, Carmen T.A. Usos e abusos do conceito de transposição didática - considerações a partir do campo disciplinar de História. Anais do IV Seminário Perspectivas do Ensino de História, Ouro Preto, 2001.

GAGLIARDI, R. Cómo utilizar la historia de las ciencias en la enseñanza de las ciencias. Enseñanza de las Ciencias 6 (3): 291-296, 1988.

GIL PÉREZ, D.; MONTORO, I. F.; ALIS, J. C.; CACHAPUZ, A.; PRAIA, J. Para uma imagem não deformada do trabalho científico. Ciência \& Educação 7 (2): 125-153, 2001.

GINZBURG, Carlo. O fio e os rastros. Verdadeiro, falso, fictício. Trad. Rosa Freire de Aguiar e Eduardo Brandão. São Paulo: Companhia das Letras, 2006.

HANUSCIN, D. L.; AKERSON, V. L.; PHILLIPSON-MOWER, T. Integrating nature of science instruction into a physical science content course for preservice elementary teachers: NOS views of teaching assistants. Science Education 90: 912-935, 2006.

HARRÉ, R. As filosofias da ciência. Lisboa: Edições 70, 1988.

HEMPEL, C. G. Explicação científica. In: MORGENBESSER, S. (Org.). Filosofia da ciência. São Paulo: Cultrix, 1979.

HESSEN, Boris. Las raíces socioeconómicas de la mecánica de Newton. Habana: Editorial Academia, 1985.

As raízes sócio-econômicas dos Principia de Newton. In: GAMA, Ruy. Ciência e técnica: antologia de textos históricos. São Paulo: T.A. Queiroz, 1992.

HETHERINGTON, N.S. The history of science and the teaching of science literacy. Journal of Thought 17 (2): 53-66, 1982.

HOLTON, Gerald. What historians of science and science educators can do for one another? Science Education 12 (7): 603-616, oct. 2003.

JARDINE, Nick, Whigs and stories: Herbert Butterfield and the historiography of science. History of Science [part 2] 41 (132): 125-140, June 2003.

KOYRÉ, Alexandre. Estudos da História do Pensamento Científico. Trad. Márcio Ramalho. Rio de Janeiro: Ed. Forense Universitária; Brasília: Ed. Universidade de Brasília, 1982.

KRAGH, H. An introduction to the historiography of science. Cambridge: Cambridge U.P., 1987.

KUHN, Thomas S. A estrutura das revoluções científicas. 5a. Ed. São Paulo: Editora Perspectiva, 1997.

LEDERMAN, Norman G. Nature of science: past, present, and future. In: ABELL, S.K.; LEDERMAN, N.G. (Eds.), Handbook of research on science education. Mahwah, NJ: Lawrence Erlbaum Associates, 2007, p. 831-880.

LEVITT, T. Editing out caloric: Fresnel, Arago and the meaning of light. British Journal of the History of Science 33 (116): 49-65, 2000.

LEITE, Mirian Soares. Contribuição de Basil Bernstein e Yves Chevallard para a discussão do conhecimento escolar. Dissertação de Mestrado. Rio de Janeiro, PUC, 2004.

LIMA-TAVARES, Marina; El-HANI, Charbel Niño. Um olhar epistemológico sobre a transposição didática da teoria gaia. Investigações em Ensino de Ciências 6 (3): 299-336, 2001.

LINDBERG, D.C. Theories of vision from Al-Kind to Kepler. Chicago: University of Chicago Press, 1976.

The beginnings of western science: the European scientific tradition in philosophical, religious, and institutional context, 600 B.C. to A.D. 1450. Chicago: University of Chicago Press, 1992. 
LLOYD, G. E. R. Methods and Problems in the History of Ancient Science. The Greek Case. Isis 83: 564-577, 1992.

LÜDKE, M.; ANDRÉ, M.E.D.A. Pesquisa em educação: abordagens qualitativas. São Paulo: EPU, 1986.

MANUEL, D.E. Reflections of the role of history \& philosophy of science in school science education. School Science Review 62 (221): 769-771, 1981.

MARANDINO, M. Transposição ou recontextualização? Sobre a produção de saberes na educação em museus de ciências. Revista Brasileira de Educação 26: 95-108, 2004.

MARTINS, André F.P. História e filosofia da ciência no ensino: há muitas pedras nesse caminho. Caderno Brasileiro de Ensino de Física 24 (1): 112-131, 2007.

MARTINS, Lilian A.C.P. A história da ciência e o ensino de biologia. Ciência \& Educação 5: 1821, dez. 1998.

História da ciência: objetos, métodos e problemas. Ciência \& Educação 11 (2), 2005.

MARTINS, Roberto de Andrade. Sobre o Papel da História da Ciência no Ensino. Boletim SBHC. 9: 3-5, 1990.

Em busca do nada: considerações sobre os argumentos a favor do vácuo ou do éter. Trans/Form/Ação 16: 7-27, 1993.

O Universo: teorias sobre sua origem e evolução. São Paulo: Moderna, 1996. Disponível em: http://www.ifi.unicamp.br/ ghtc/Universo/. Acesso em: 15 fev. 2007.

Descartes e a impossibilidade de ações a distância. In: FUKS, S. (Ed.), Descartes 400 anos. Um legado científico e filosófico, Rio de Janeiro, Relume Dumará, 1998, p. 79-126.

O que é a ciência do ponto de vista da epistemologia? Caderno de Metodologia e Técnica de Pesquisa 9: 5-20, 1999.

Como não escrever sobre história da física - um manifesto historiográfico. Revista Brasileira de Ensino de Física 23 (1): 113-129, 2001.

O retorno do éter. Scientific American Brasil 2: 27-27, julho de 2002.

Ciência versus historiografia: os diferentes níveis discursivos nas obras sobre história da ciência. In: ALFONSO-GOLDFARB, A.M.; BELTRAN, M.H.R. Escrevendo a história da ciência: tendências, propostas e discussões historiográficas. São Paulo: Educ; Fapesp; Editora Livraria da Física, 2004. p. 115-145.

. A Torre de Babel científica. Scientific American - os grandes erros da ciência, Especial História 6: 6-13, 2006a.

Do éter ao vácuo e de volta ao éter. Scientific American - os grandes erros da ciência, Especial História 6: 92-98, 2006b.

O surgimento da teoria da relatividade restrita. In: CARDOSO, Walmir Thomazi; SILVA, Cibelle Celestino (eds.). Tópicos de história das ciências naturais. São Paulo: Editora Manole (no prelo).

MARTINS, Roberto de Andrade e SILVA, Cibelle Celestino. Newton and colour: the complex interplay of theory and experiment. Science \& Education 10 (3): 287-305, 2001.

MATTHEWS, M.R.. A role for history and philosophy in science teaching. Interchange 20 (2): 3$15,1989$.

Science teaching - the role of history and philosophy of science. Nova York: Routledge, 1994, 287p. 
História, Filosofia e Ensino de Ciências: a Tendência Atual de Reaproximação. Cadernos Catarinenses de Ensino de Física 12 (3): 164 - 214, 1995.

MAYRARGUE, A. Fresnel and optical ether. La Recherche 21 (218): 234-237, 1990.

McCOMAS, W.; ALMAZROA, H.; CLOUGH, M. P. The nature of science in science education: an introduction. Science \& Education 7: 511-532, 1998.

MCGUIRE, J.E.; RATTANSI, P. M. Newton and the 'Pipes of Pan'. Notes and Records of Royal Society 21: 108-143, 1966.

MEDEIROS; A.; BEZERRA FILHO, S. A natureza da ciência e a instrumentação para o ensino da física. Ciência \& Educação 6 (2): 107-117, 2000.

MONTEIRO, F. C. Entre o estranho e o familiar: o uso de analogias no ensino de história. Cadernos CEDES 25 (67) Campinas, Sept./Dec. 2005. Disponível em: $<$ http://www.scielo.br/scielo.php?pid=S0101-32622005000300006\&script=sci_arttext\&tlng=pt $>$. Acesso em: 3 fev. 2008.

MORTIMER, E. F.; CARVALHO, A. M. P. de. Referenciais teóricos para análise do processo de ensino de ciências. Cadernos de Pesquisa. São Paulo 96: 5 -14, 1996.

MOURA, Breno A. Newton $x$ Huygens: como (não) ocorreu a disputa entre suas teorias para a luz. ArScientia, 2007. Disponível em: http://www.arscientia.com.br/ materia/ver_materia.php?id_materia=415. Acesso em: 15 jan. 2008.

MOURA, Breno A.; SILVA, Cibelle Celestino. A teoria dos estados da luz: um estudo dos papéis das hipóteses na óptica newtoniana. In: MARTINS, R.A.; SILVA, C.C.; FERREIRA, J.M.H. e MARTINS, L.A.C.P. Filosofia e História da Ciência no Cone Sul - Atas do V Encontro. Campinas: Associação de Filosofia e História da Ciência no Cone Sul, 2008.

Newton antecipou o conceito de dualidade onda-partícula da luz? Latin American Journal Physics Education 2 (3): 218-227, Sept. 2008.

NASCIMENTO, U. On the trail of Fresnel's search for an Ether Wind. Apeiron 5: 181-192, 1998.

NEEDHAM, Joseph. De la Ciencia y la Tecnología Chinas. México, Siglo Veintiuno Editores, 1978.

NERSESSIAN, N. J. Aether/or: the creation of scientific concepts. Studies in the History and Philosophy of Science 15: 175-212, 1984.

NEWTON, Isaac. Óptica. Edusp: São Paulo, 1996.

Mathematical principles of natural philosophy. Optics. Trad. A. Motte. [2a.ed]. Chicago, Encyclopaedia Britannica, 1952. (Col. Great Books of Western World, V. 34).

NIAZ, M. Understanding nature of science as progressive transitions in heuristic principles. Science Education 85: 684-690, 2001.

OLIVEIRA, Sara L. Desafios sobre a escrita da história: considerações sobre o anacronismo. Perg@minho - revista eletrônica de história. UFPB, out., 2005. Disponível em: $<$ http://www.cchla.ufpb.br/pergaminho/>. Acesso em: 4 nov. 2008.

OLIVEIRA, B. J.; FREIRE-Jr, O. Uma conversa com Gerald Holton. Caderno Brasileiro de Ensino de Física 23 (3): 315-328, dez. 2006.

PAGLIARINI, Cassiano R. Uma análise da história e filosofia da ciência presente em livros didáticos de física para o ensino médio. Dissertação de Mestrado. Instituto de Física da Universidade de São Paulo/São Carlos, 2007.

PARK, D. The fire within the eye: a historical essay on the nature and meaning of light. Princeton University Press, 1997. 
PEDUZZI, L. Sobre a utilização didática da história da ciência. In: PIETROCOLA, M. (Org.) Ensino de Física - conteúdo, metodologia e epistemologia numa concepção integradora. Florianópolis: Editora UFSC, 2001.

PIAGET, J; GARCIA, R. Psicogénesis e Historia de la Ciencia. Mexico: Siglo Veintiuno, 1984.

PIETROCOLA, Maurício. Mascart et l'Optique de corps en mouvement. Tese de Doutorado. Paris, Université de Paris, 1992.

O éter luminoso como espaço absoluto. Cadernos de História e Filosofia da Ciência [série 3] 3 (1/2): 163-182, 1993a.

Fresnel e o arrastamento parcial do éter: a influência do movimento da Terra sobre a propagação da luz. Caderno Catarinense de Ensino de Física 10 (2): 157-172, 1993 b.

Construção e Realidade: O realismo científico de Mario Bunge e o ensino de ciências através de modelos. Investigações em Ensino de Ciências 4 (3), dez. 1999. Disponível em: www.if.ifrgs.br/public/ensino/revista.htm. Acesso em: 4 abr. 2005.

A Matemática como estruturante do conhecimento físico. Caderno Brasileiro de Ensino de Física 19 (1): 93-114, ago. 2002.

O espaço pleno e a concepção do éter. A Física na Escola, 3 (2): 7-8, outubro de 2002.

A história e a epistemologia no ensino de ciências: dos processos aos modelos de realidade na educação científica. In: ANDRADE, A.M.R. (Org.) Ciência em Perspectiva. Estudos, Ensaios e Debates. Rio de Janeiro: MAST/SBHC, 2003. p. 133-149.

A transposição da física moderna e contemporânea para o ensino médio: superando obstáculos epistemológicos e didático-pedagógicos. In: BORGES, Regina. (Org.). Propostas Interativas na Educação Científica e Tecnológica. Porto Alegre: EDUC, 2008.

PUMFREY, S. History of science in the National Science Curriculum: a critical review of resources and their aims. British Journal of History of Science 24: 61-78, 1991.

RATTANSI, Piyo M. Newton and the Wisdom of the Ancients. In: FLAUVEL, J.; FLOOD, R.; SHORTLAND, M.; WILSON, R. Let Newton Be! Oxford; New York: Oxford University Press, 1988, p. 185-201.

REZENDE, F.; RUBINO, L.; QUEIROZ, G.R.P.C. Planejamentos de aulas de Física: uma análise do conhecimento pedagógico do conteúdo. X Encontro de Pesquisa em Ensino de Física. Londrina. Atas do X EPEF, 2006.

RICARDO, Elio Carlos. Competências, interdisciplinaridade e contextualização: dos parâmetros curriculares nacionais a uma compreensão para o ensino de ciências. Tese de Doutorado. Florianópolis, UFSC, 2005.

ROCHBERG, F. et alii. The cultures of Ancient Science: Some Historical Reflections. Isis 83: 547607, 1992.

RODRIGUES, Maria Inês Ribas Professores-Pesquisadores: Reflexão e a Mudança Metodológica no Ensino da Termodinâmica. Dissertação de Mestrado. São Paulo, Instituto de Física da USP, 2001.

RONCA, P.A.C.; TERZI, C. do A. A prova operatória. Contribuições da psicologia do desenvolvimento. $5^{\text {a }}$. Ed. São Paulo: Dag Gráfica e Editorial Ltda, 1993.

ROSSI, Paolo. A ciência e a filosofia dos modernos. Tradução Álvaro Lorencini. São Paulo: Unesp, 1992.

Naufrágios sem espectador. A idéia de progresso. Tradução A. Lorencini. São Paulo: Unesp, 2000.

RUSSEL, T. L. What history of science, how much and why? Science Education 65: 51-64, 1981. 
SABRA, A.I. Theories of light from Descartes to Newton. London: Cambridge University Press, 1981.

SANTOS, F.M.T.; GRECA, I.M. (orgs.) A pesquisa em ensino de ciências no Brasil e suas metodologias. Unijuí, Ed. Unijuí, 2006.

SCHWARTZ, R.S.; LEDERMAN, N.G.; CRAWFORD, B.A. Developing views of nature of science in an authentic context: an explicit approach to bridging the gap between nature of science and scientific inquiry. Science Education 88: 610-145, 2004.

SIEGEL, H. On the distortion of the history of science in science education. Science Education 63: 277-278, 1979.

SILVA, Cibelle C. (Org.). Estudos de história e filosofia das ciências: subsídios para aplicação no ensino. São Paulo: Editora Livraria da Física, 2006.

SILVA, Cibelle C. e MARTINS, Roberto de A. A "Nova teoria sobre luz e cores" de Isaac Newton: uma tradução comentada. Revista Brasileira de Ensino de Física 18 (4): 313-27, 1996.

. A teoria das cores de Newton: um exemplo do uso da história da ciência em sala de aula. Ciência \& Educação 9 (1): 53-65, 2003.

SILVA, F. W. O. A evolução da teoria ondulatória da luz e os livros didáticos. Revista Brasileira de Ensino de Física 29 (1): 149-159, 2007.

SIQUEIRA, Maxwell R. P. Do visivel ao indivisível: uma proposta de Física de Partículas Elementares para o Ensino Médio. Dissertação de Mestrado. São Paulo, Instituto de Física e Faculdade de Educação da USP, 2006

SWENSON, Loyd S. The ethereal Aether - a history of the Michelson-Morley-Miller aether drift experiments, 1880 -1930. Austin, University of Texas Press, 1972.

VALENTE, Wagner Rodrigues. Saber científico, saber escolar e suas relações: elementos para reflexão sobre a didática. Revista Diálogo Educacional, Curitiba, 4 (10): 57-67, set./dez. 2003.

VANNUCCHI, A.I. História e filosofia da ciência: da teoria para a sala de aula. Dissertação de Mestrado. São Paulo, Faculdade de Educação, USP, 1996.

WEINBERG, S. Can science explain everything? Anything? The New York Review of Books. 48 (9), 2001. Disponível em: www.nybooks.com/articles/14263. Acesso em: 10 jun. 2005. Trad. Brasileira de José Marcos Macedo. Os limites da explicação científica. Disponível em: www.cfh.ufsc.br/ wfil/limit.htm. Acesso em: 10 jun. 05.

WHITAKER, M. A. B. History and quasi-history in physics education - part 1. Physics Education 14: 108-112, 1979.

WHITTAKER, E. T. A history of the theories of Aether and electricity. London, Nelson, 1953. 2 vols. (Reimpresso como Vol. 7 na serie The history of modern physics, 1800-1950. Thomas Publishers/American Institute of Physics, 1987.)

WORRALL, J. How to remain (reasonably) optimistic: scientific realism and the luminiferous ether. PSA: Proceedings of the Biennial Meeting of the Philosophy of Science Association 1: 334$342,1994$. 